\title{
A ÁRVORE NA PROPRIEDADE RURAL: EDUCAÇÃO, LEGISLAÇÃO E POLÍTICA AMBIENTAL NA PROTEÇÃO E IMPLEMENTAÇÃO DO ELEMENTO ARBÓREO NA REGIÃO DE PIRACICABA / SP
}

\author{
ISIS AKEMI MORIMOTO
}

Dissertação apresentada à Escola Superior de Agricultura "Luiz de Queiroz", Universidade de São Paulo, para obtenção do título de Mestre em Recursos Florestais, com opção em Conservação de Ecossistemas Florestais.

PIR A C ICABA

Estado de São Paulo - Brasil

Abril - 2002 


\title{
A ÁRVORE NA PROPRIEDADE RURAL: EDUCAÇÃO, LEGISLAÇÃO E POLÍTICA AMBIENTAL NA PROTEÇÃO E IMPLEMENTAÇÃO DO ELEMENTO ARBÓREO NA REGIÃO DE PIRACICABA / SP
}

\author{
ISIS AKEMI MORIMOTO \\ Ecóloga \\ Orientador: Prof. Dr. MARCOS SORRENTINO
}

Dissertação apresentada à Escola Superior de Agricultura "Luiz de Queiroz", Universidade de São Paulo, para obtenção do título de Mestre em Recursos Florestais, com opção em Conservação de Ecossistemas Florestais.

PIR A C I C A B A

Estado de São Paulo - Brasil

Abril - 2002 


\title{
Dados Internacionais de Catalogação na Publicação (CIP) DIVISÃO DE BIBLIOTECA E DOCUMENTAÇÃO - ESALQ/USP
}

\author{
M orimoto, Isis A kemi \\ A árvore na propriedade rural: educação, legislação e política ambiental na \\ proteção e implementação do elemento arbóreo na região de Piracicaba / SP / Isis \\ A kemi M orimoto. - - Piracicaba, 2002. \\ 205 p. : il. \\ Dissertação (mestrado) - - Escola Superior de A gricultura Luiz de Q ueiroz, \\ 2002. \\ Bibliografia. \\ 1. Á rvore 2. Impacto ambiental 3. Legislação ambiental 4. M eio ambiente \\ (Educação) 5. Política ambiental 6. Propriedade rural 7. Proteção ambiental I. Título \\ CDD 634.94
}

"Permitida a cópia total ou parcial deste documento, desde que citada a fonte - $\mathrm{O}$ autor" 


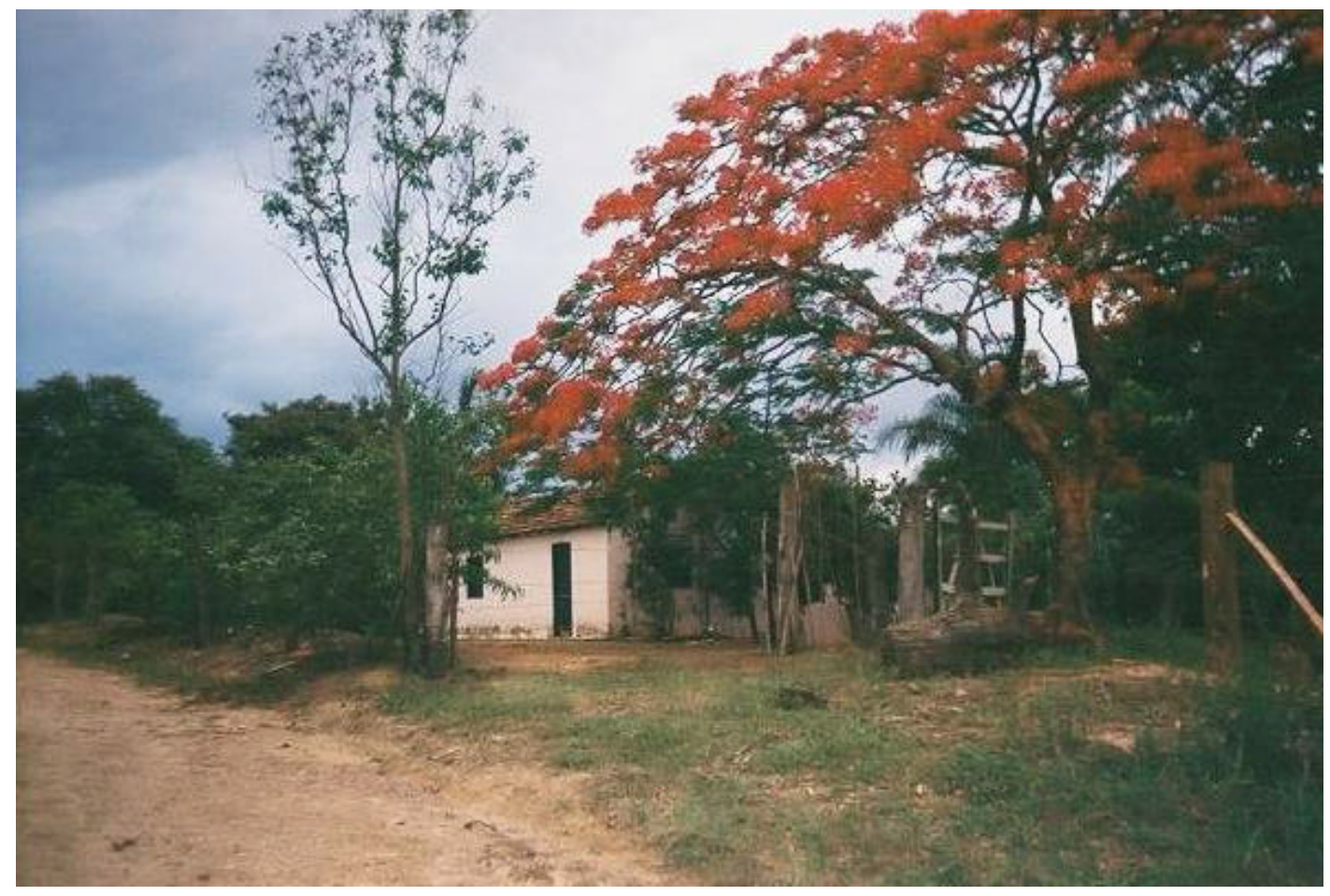

Viver em harmonia com a Natureza...

Para os humanos, é como respeitar o próprio corpo;

Para o planeta, é como alimentar a sua alma. 
Aos meus pais Adilva e Siniti Dedico 


\section{AGRADECIMENTOS}

Ao Prof. Dr. Marcos Sorrentino que me orientou com dedicação, competência e amizade.

Ao Prof. Dr. Paulo Affonso Leme Machado, pela co-orientação e pelo incentivo que tem me fornecido desde a graduação, para que eu aprofunde meus estudos.

À Professora Dra. Maria José Brito Zákia, pelo grande auxílio em diversos momentos e pela amizade.

Ao Prof. Dr. Dálcio Caron, que também me ajudou muito durante a elaboração desta dissertação e se mostrou um bom amigo.

À Nina da Casa da Agricultura, que me acompanhou nas visitas às propriedades rurais e foi bastante atenciosa sempre que necessitei de sua ajuda.

Aos proprietários rurais que me receberam muitíssimo bem. Em especial às famílias Oliveira, Segredo e Mantelatto.

Ao Professor Dr. Luiz Gonzaga E. Lordelo, que foi muito simpático ao responder meu questionário piloto, e que nos deixou este ano.

À Professora Dra. Celina Foresti, a quem também presto homenagens póstumas, pelo auxílio durante a elaboração do meu projeto de pesquisa.

À Flávia, do Consórcio Intermunicipal das Bacias dos Rios Piracicaba, Capivari e Jundiaí, que ministrou palestra para os proprietários rurais.

Ao Marcos Faraht, que auxiliou na divulgação das palestras na Coopercana.

Aos alunos da Disciplina Política, Legislação e Administração Florestal, que prestaram auxílio na aplicação dos questionários.

À Usina Costa Pinto e à Cooperativa dos Plantadores de Cana-de-açúcar, que cederam espaço para que eu realizasse palestras.

A todos que responderam aos questionários. 
Ao Carlinhos, pela revisão do trabalho e pelo companheirismo e compreensão durante todo o decorrer da pesquisa.

À Flávia Rossi, pela ajuda e amizade nos momentos que precisei.

À todos os amigos que estiveram presentes.

Aos companheiros do cursos de Direito, pela ajuda e compreensão em minhas ausências.

Ao Vilson Previde, pela ajuda em meus estudos e pela amizade.

À minha irmã, pelas palavras de incentivo.

Aos meus pais, que me ajudaram o tempo todo e sofreram comigo em todas as dificuldades.

Ao Departamento de Ciências Florestais da ESALQ/USP, pela oportunidade de cursar o programa de pós-graduação em Recursos Florestais.

Aos funcionários do Departamento de Ciências Florestais, em especial ao Alexandre e a Margareth, pelo apoio.

Ao Laboratório de Educação e Política Ambiental, por me receber e ceder espaço para o desenvolvimento de meus trabalhos.

Aos companheiros e amigos com os quais convivo no LEPA.

Enfim, a todos que me deram alegria; a todos que me ajudaram a crescer; a todos que amo.

Agradeço em especiais à CAPES e à FAPESP, pelo apoio financeiro cedido para a realização da presente pesquisa. 


\section{SUMÁRIO}

Página

LISTA DE FIGURAS................................................................................ viii

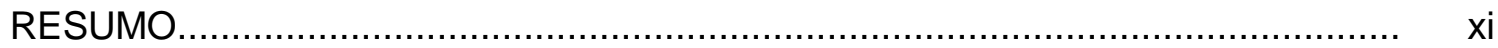

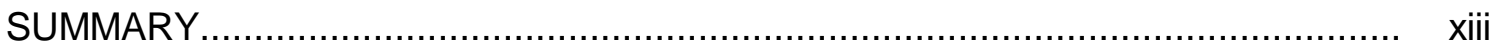

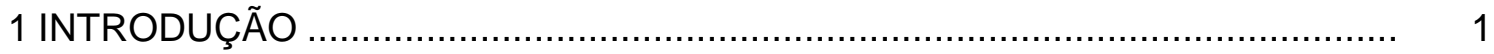

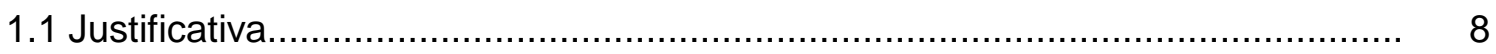

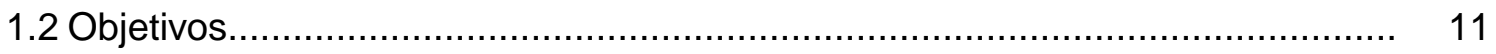

2 REVISÃO DE LITERATURA............................................................. 12

2.1 Um pouco de História - A Floresta e os Humanos......................................... 12

2.2 A Educação Para Um Meio Ambiente Equilibrado....................................... 16

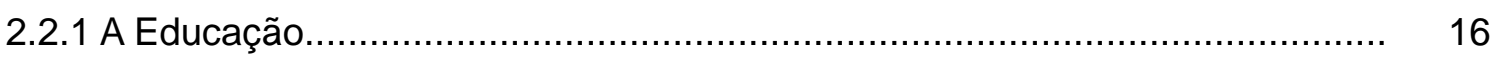

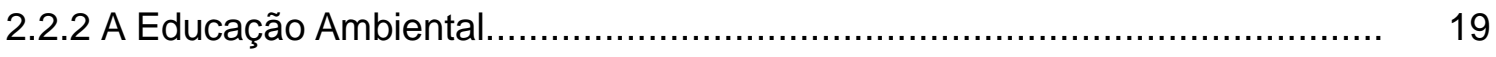

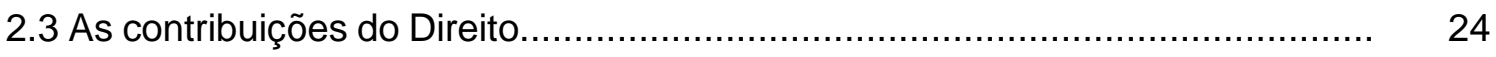

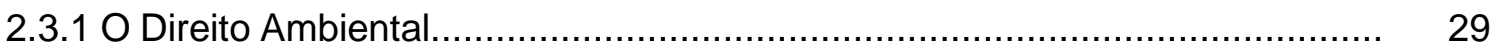

2.3.2 A Participação Política.................................................................... 30

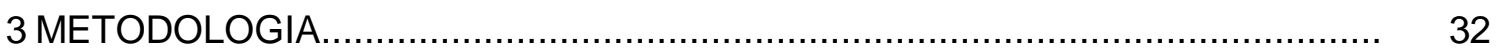

3.1 Fundamentação Teórica............................................................... 32

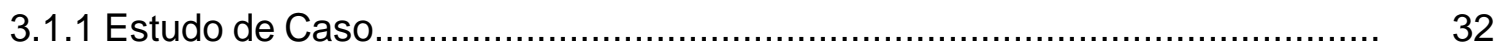

3.1.2 Pesquisa-Ação e Pesquisa Participante................................................ 33

3.1.3 Entrevistas e Questionários............................................................... 34

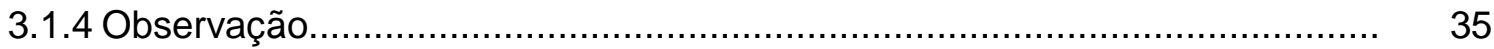

3.1.5. Pesquisa Qualitativa e Quantitativa.................................................... 36

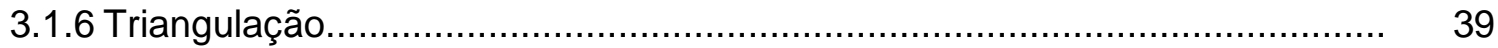

3.2 Escolha do público alvo e da área de estudo............................................. 41

3.3 Diagnóstico de Percepção...................................................................... 45

3.3.1 Procedimentos para Estratificação dos Resultados................................... 49 
3.4 Outras fontes de informação................................................................. 58

3.4.1 Profissionais da área....................................................................... 58

3.4.2 Atividades Complementares............................................................ 59

3.5 Desenvolvimento do processo de intervenção educacional............................ 60

3.5.1 Palestra de Planejamento e Divulgação ................................................... 62

3.5.2 Elaboração de um Cronograma de Palestras ............................................ 62

3.6 Análise dos resultados ............................................................................ 63

4 RESULTADOS E DISCUSSÃO.................................................................. 64

4.1 Público Alvo e área de estudo.................................................................. 64

4.2 Diagnóstico de Percepção................................................................. 66

4.2.1 Gráficos de respostas obtidas nos questionários aplicados pela pesquisadora e pelos estudantes de graduação................................................................. $\quad 75$

4.2.2 Estratificação dos Resultados............................................................... 95

4.2.3 Análises da Percepção ................................................................. 97

4.2.4 Declarações Importantes dos Proprietários Rurais ..................................... 99

4.3 Resultados de outras fontes de informação................................................ 116

4.4 Palestra de divulgação................................................................... 121

4.5 Conjunto de Atividades Educacionais................................................... 124

4.6 Curso Idealizado …….................................................................. 125

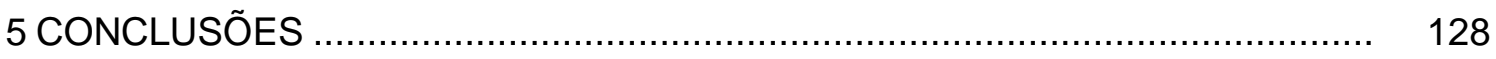

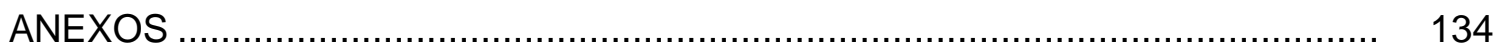

REFERÊNCIAS BIBLIOGRÁFICAS ................................................................. 197 


\section{LISTA DE FIGURAS}

Página

1 Proprietário rural e a mangueira que alimenta a família por gerações................. 12

2 Córrego Tamandupá, bastante degradado................................................... 42

3 Localização da Microbacia Tamandupá........................................................ 43

4 Cana-de-açúcar, paisagem comum na região.............................................. 44

5 Microbacia Tamandupá dividida em quadrantes........................................ 47

6 Alunos e proprietário rural................................................................. 49

7 Margem do rio Corumbataí sem cobertura florestal...................................... 65

8 Área desmatada e com gado nas margens................................................ 66

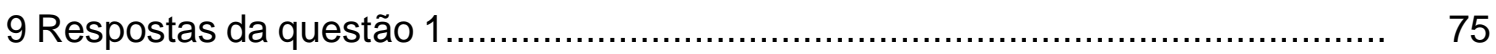

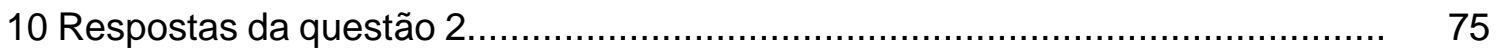

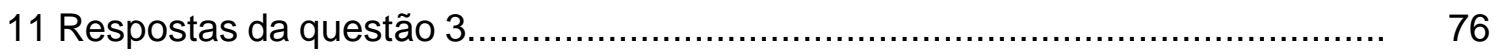

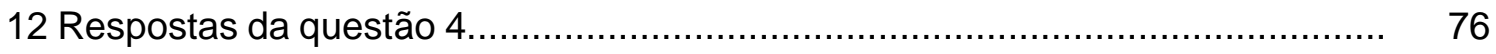

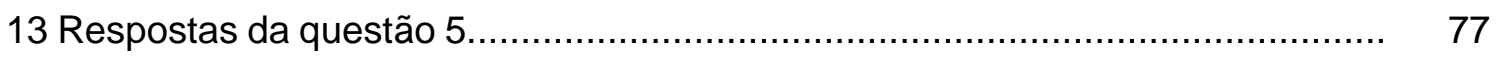

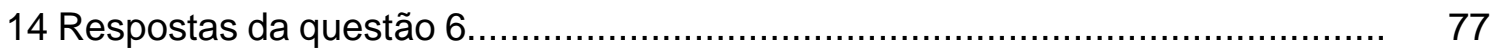

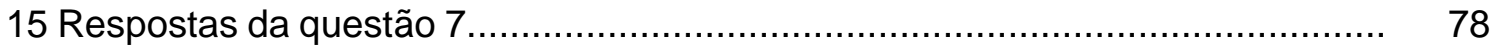

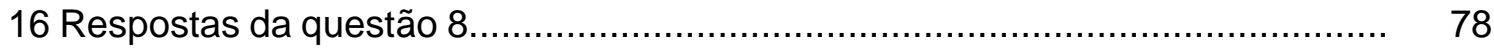

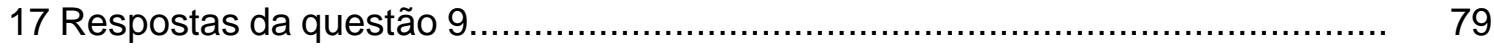

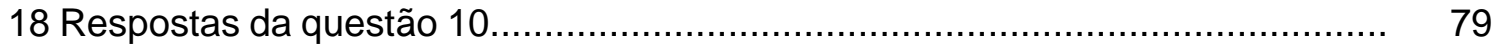

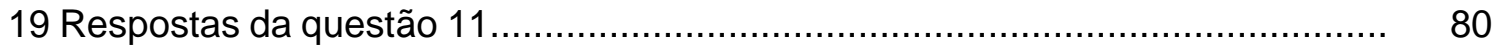

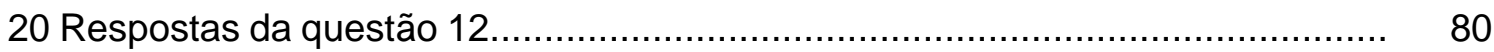

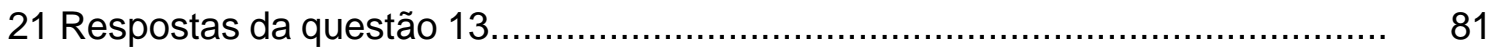

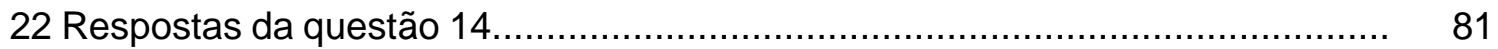

23 Respostas da questão 15................................................................... 82

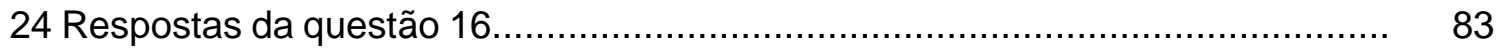

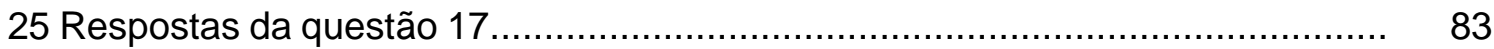




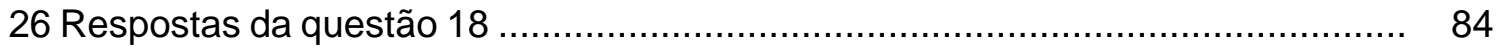

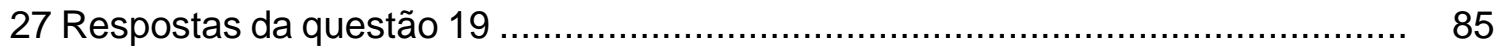

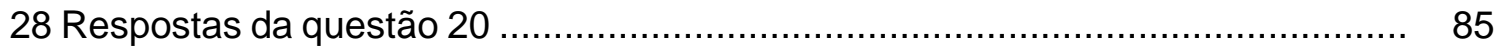

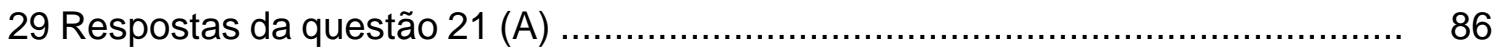

30 Respostas da questão 21 (B) ............................................................. 86

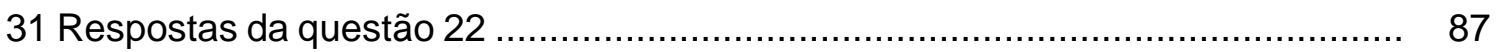

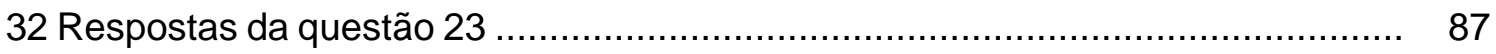

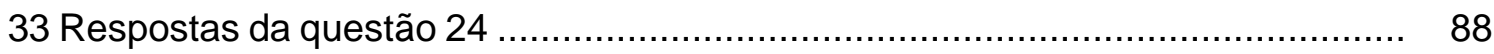

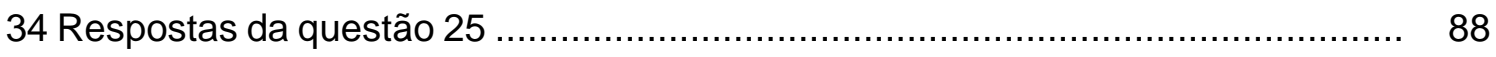

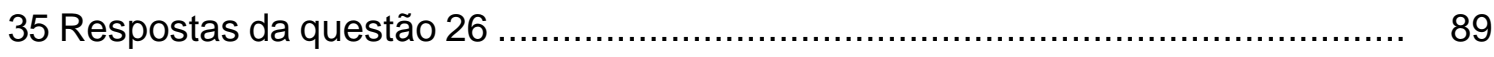

36 Respostas da questão 27 .............................................................. 89

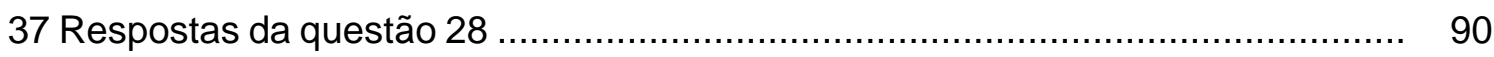

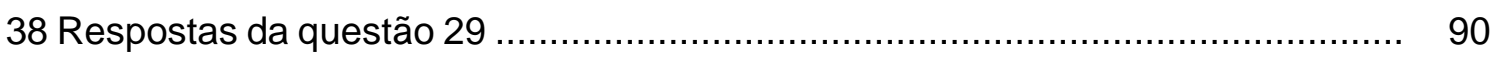

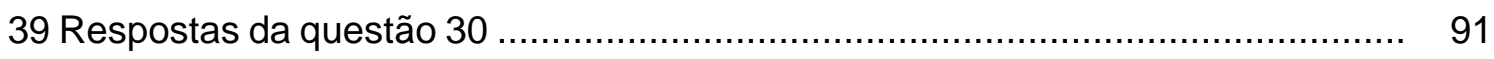

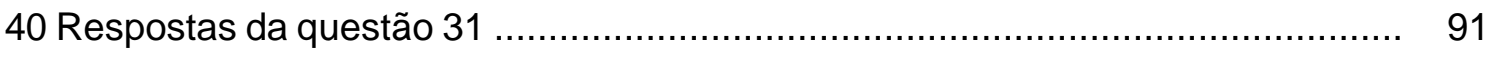

41 Respostas da questão 32 .............................................................. 92

42 Respostas da questão $33(\mathrm{~A})$............................................................ 92

43 Respostas da questão $33(B)$............................................................ 93

44 Respostas da questão $33(C)$............................................................. 93

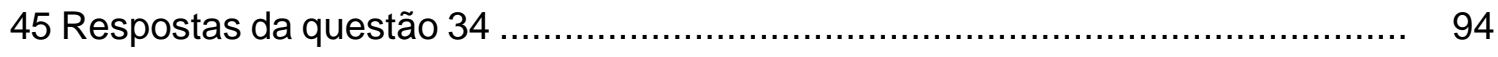

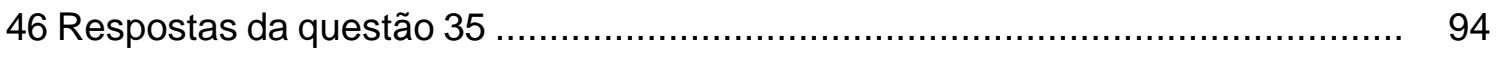

47 Palestra de divulgação........................................................................... 122

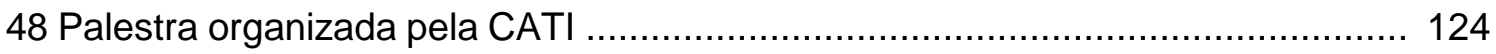

49 Palestra sobre programas de auxílio ao reflorestamento e proteção ao meio

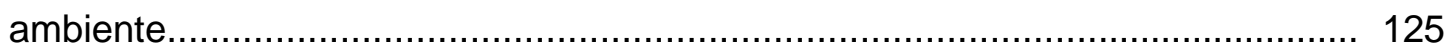




\section{LISTA DE QUADROS}

Página

1 Quadro Síntese da Legislação da Educação Ambiental................................... 27

2 Quadro de Importantes Leis Ambientais........................................................ 28

3 Quadro de distribuição dos proprietários rurais nos quadrantes....................... 47

4 Quadro de resultados do questionário aplicado aos proprietários rurais............ 67

5 Estratificação dos resultados: Percepção X Tamanho da Propriedade.............. $\quad 95$

6 Estratificação dos resultados: Percepção X Grau de Escolaridade.................... $\quad 96$

7 Estratificação dos resultados: Percepção X Idade e Residência......................... 96

8 Características dos entrevistados................................................................. 141 


\section{A ÁRVORE NA PROPRIEDADE RURAL: EDUCAÇÃO, LEGISLAÇÃO E POLÍTICA AMBIENTAL NA PROTEÇÃO E IMPLEMENTAÇÃO DO ELEMENTO ÁRBÓREO NA REGIÃO DE PIRACICABA / SP}

Autora: Isis Akemi Morimoto

Orientador: Prof. Dr. Marcos Sorrentino

\section{RESUMO}

Diante da contínua e crescente degradação das florestas e das dificuldades que a sociedade enfrenta no sentido de protegê-las e recuperá-las, este trabalho foi realizado com o intuito de contribuir para a valorização, proteção e implantação de árvores e florestas em propriedades rurais no município de Piracicaba/SP. Para tanto, efetuou-se uma pesquisa sobre a percepção que os produtores da Microbacia Tamandupá, tributária do Rio Corumbataí, possuem em relação ao elemento arbóreo e aos dispositivos de proteção ao mesmo, para que ao final, fossem propostas diretrizes para intervenções educacionais voltadas ao setor rural. Utilizando-se de contribuições conceituais e metodológicas advindas da educação, legislação e política ambiental, bem como das reflexões obtidas através de entrevistas com profissionais dessas áreas e da extensão rural, procurou-se construir um referencial teórico para analisar os dados de campo. Os resultados obtidos durante as entrevistas realizadas, foram analisados de forma qualitativa e quantitativa. Buscou-se também, realizar a estratificação dos dados, ou seja, a separação das respostas de acordo com características sócio-econômicas dos entrevistados para identificar padrões entre as mesmas. A intenção era avaliar o grau de percepção dos proprietários em relação ao 
elemento arbóreo e às leis, de modo a caracterizá-los de acordo com o grau de escolaridade, a idade, o tamanho das propriedades e o fato dos proprietários residirem ou não no campo. Não foi possível verificar grandes variações de respostas, que demonstrassem um pensamento comum para cada grupo, mas apontaram-se tendências que possibilitaram concluir, por exemplo, que os proprietários que residem no campo possuem maior identificação e afinidade em relação ao elemento arbóreo. Os dados obtidos contribuíram ainda, para a identificação de algumas frases bastante indicativas do pensamento, dos desejos e das opiniões dos agricultores, o que pode auxiliar na compreensão da realidade do setor e orientar trabalhos no sentido de instrumentalizar a tomada de decisões direcionadas à proteção ambiental. Conclui-se que o trato junto ao público alvo da presente pesquisa, é complexo e necessita de dedicação e continuidade. Deve-se sempre propiciar a participação dos mesmos em todas as etapas de trabalho, e observar métodos múltiplos de abordagem e intervenções. Outras formas de aproximação são também sugeridas, como por exemplo, as conversas informais, o contato via sindicato e a participação em eventos comuns aos produtores. Além disto, faz-se necessário o envolvimento de pessoas que podem influenciar na tomada de decisões (como caseiros, cônjuges, crianças, etc.). As intervenções educacionais devem contemplar procedimentos e conteúdos variados. Neste sentido, a promoção da sinergia entre educação, legislação e política, pode trazer grandes contribuições. A educação deve instigar o questionamento, o debate e as atitudes, enquanto que as leis podem representar a efetivação de acordos compactuados entre as pessoas e possibilitar o exercício da crítica, além de direcionar a criação de políticas efetivas de proteção ao meio ambiente. Sendo assim, vale ressaltar que a despeito das dificuldades existentes no processo de busca pela proteção e implementação do elemento arbóreo em propriedades rurais, existem perspectivas concretas de se reverter o quadro de degradação do ambiente que se observa na região e no mundo. 


\title{
THE TREE IN THE COUNTRY PROPERTY: EDUCATION, LEGISLATION AND ENVIRONMENTAL POLITICS FOR THE PROTECTION AND IMPLEMENTATION OF ARBOREAL ELEMENT IN THE REGION OF PIRACICABA/SP
}

\author{
Author: Isis Akemi Morimoto \\ Adviser: Prof. Dr. Marcos Sorrentino
}

\section{SUMMARY}

Due the continuum and increasing degradation of the forests and the difficulties that the society faces to protect and to recover them, this work was made to contribute for the valuation, protection and implantation of trees and forests in country properties of Piracicaba /SP. For in such a way, a research was effected on the perception that the producers of the Microbacia Tamandupá, of the River Corumbataí, have in relation to the arboreal element and the ways of protection, so that to the end, proposals lines of direction to educational interventions. Using of conceptual and methodological contributions from the education, legislation and ambient politics, as well as from the reflections gotten from interviews with professionals of these areas and of the agricultural extension, it was looked to construct a theoretical referential to analyze the field data. The results gotten during the interviews, had been analyzed in a qualitative and quantitative ways. One of the goals was to carry through the stratification of the data, or either, the separation of the results according to the sociological and economic 
characteristics of the interviewees, to identify standards among them. The idea was to evaluate the degree of perception of the owners in relation to the arboreal element and the laws, in order to characterize them according to the scholarship degree, the age, the size of the properties and the fact of the proprietors to inhabit or not in the field. It was not possible to verify great variations of answers, that demonstrated a common thought for each group, but had pointed trends that they make possible to conclude, for example, that the proprietors who inhabit in the field possess greater identification and affinity in relation to the arboreal element. Those data had still contributed, for the identification of some sufficiently indicative phrases of the thought, the desires and the opinions of the agriculturists, what can assist the understanding of the reality of the sector and guide works to the instrumentalization of taking decisions directed to the ambient protection. The treatment to the public of the present research, is complex and needs devotion and continuity. It must be propitiated the participation of same in all the stages of work, and always be observed multiple methods of boarding and interventions. Other forms of approach also are suggested, as for example, the informal colloquies, the contact through union and the participation in common events to the producers. Moreover, the involvement of people who can influence in the taking of decisions (as caretakers, partners, children, etc.) becomes necessary. The educational interventions must contemplate varied procedures and contents. In this direction, the promotion of the synergy between education, legislation and politics, can bring great contributions. The education must instigate the questioning, the debate and the attitudes, while the laws can represent the effectuation of agreements done between the people and make possible the exercise of the criticism, besides directing the creation of effective politics to protect the environment. In spite of the existing difficulties in the process of fetching the protection and implementation of the arboreal element in agricultural properties, there is a real perspective of reverting the picture of degradation of the environment that is seen in the region and in the world. 


\section{INTRODUÇÃO}

A destruição das florestas é uma das maiores preocupações da nossa época. A cada ano, o mundo perde cerca de 15 milhões de hectares de sua cobertura arbórea. Entre os problemas relacionados com o desmatamento estão o esgotamento dos estoques de madeira, graves inundações, destruição acelerada do solo, desertificação gradativa e diminuição da produtividade da terra. Recentes pesquisas sugerem ainda, que a destruição das florestas agrava o efeito estufa, causado pelo dióxido de carbono que, exalado na queima de combustíveis fósseis, se acumula na atmosfera e retém o calor do Sol, contribuindo para o aquecimento global. Além disso, a cura para doenças temidas, como a AIDS e o câncer, pode se encontrar em alguma planta ainda desconhecida na floresta tropical - e se essa floresta for destruída, a humanidade estará para sempre privada desta ajuda (Perlin, 1992, p.15).

O relatório da FAO (Organização das Nações Unidas para Agricultura e Alimentação), apresentado no Congresso Mundial de Florestas em Paris (1991), demonstrou que a América Latina e o Caribe foram as regiões do planeta que mais perderam florestas tropicais, a um ritmo de 7,4 milhões de hectares anuais (Libório, 1994, p.2). Segundo dados do Ministério do Meio Ambiente, obtidos a partir de imagens reunidas pelo Instituto Nacional de Pesquisas Espaciais - INPE, em 20 anos de exploração predatória, o Brasil destruiu $13,5 \%$ da Floresta Amazônica. A área equivale a 675 mil quilômetros quadrados, mais do que a França e a Espanha juntas (Jornal O Globo, 14/05/2000). Em 1995, derrubaram-se $30 \mathrm{mil} \mathrm{km}^{2}$ de vegetação na Amazônia. Em 1999, mais 17 mil km² (Michel, 2000).

Estas ocorrências alarmantes vêm desencadeando diversas discussões a respeito da legislação florestal brasileira e das políticas públicas de proteção às florestas. Em julho de 1996, o presidente da república editou uma Medida Provisória (MP 1.511, de 25/07/1996), que aumentava a área protegida em propriedades rurais na 
Amazônia, de $50 \%$ para $80 \%$ de reserva legal em fitofisionomias florestais. Esta MP foi reeditada mais de 50 vezes e quando representantes da bancada ruralista do Congresso Nacional sugeriram sua conversão em lei com o texto alterado (ameaçando áreas protegidas em nome de expandir as fronteiras agrícolas do país), grande parte da população, destacando-se estudantes, organizações não governamentais e alguns políticos, manifestou-se favorável à proteção das áreas verdes.

A criação do Programa Nacional de Florestas através do Decreto 3.420 , de 20/04/2000, também retrata a crescente preocupação de alguns setores, com a proteção florestal. O programa pretende estabelecer políticas inter-setoriais com o objetivo de: reduzir o desmatamento; diminuir os incêndios florestais; fomentar o reflorestamento em pequenas propriedades; recuperar florestas de preservação permanente e reserva legal; estimular o uso sustentável de florestas nativas e plantadas; apoiar o desenvolvimento das indústrias de base florestal; ampliar os mercados e valorizar economicamente os serviços e benefícios das florestas e apoiar as iniciativas econômicas e sociais das populações que vivem em florestas.

Apesar destas medidas, a análise dos dados apresentados anteriormente, indicam que as florestas brasileiras encontram-se ainda bastante ameaçadas. Alguns autores procuraram explicar esta situação, estudando a eficácia (ou ineficácia) das leis e das políticas florestais existentes no país. Libório (1994, p.5), verificou que "o que se constata é o descumprimento das normas florestais, que vem ocorrendo de modo sistemático não apenas pelo seu desconhecimento, mas também, dentre outras causas, pelo imediatismo com que se costuma desenvolver a exploração econômica das florestas. Tem-se presente, com freqüência, a inoperância, a impotência e o descaso por parte dos poderes públicos competentes, que deveriam fazer cumprir a lei. De outro lado, a grande maioria da população, desinformada e, em conseqüência, desinteressada e descompromissada, assiste a toda espécie de prática predatória sem se manifestar ou colaborar com as autoridades no impedimento do que vem ocorrendo. E por fim, o infrator quase sempre permanece impune e, por isto mesmo, continua insensível ao desequilíbrio que provoca, seja por questão de sobrevivência, seja por desrespeito ou, ainda, por força de ambiciosos interesses pelo lucro a qualquer custo" (Libório, 1994, p.6).

O quadro problemático de efetivação que determinados dispositivos da legislação florestal apresenta, pode ser observado por exemplo, no art. 16 do Código 
Florestal (instituído pela lei 4.771, de 1965), que determina que cada propriedade rural na Região Sudeste deve ter $20 \%$ do total de sua área com reserva florestal, a serem averbados na matrícula do imóvel, no registro de imóveis competente. Porém, na área estudada por Libório em 1994 (pág. 196), constatou-se que apenas 32 das 4.025 propriedades da região, possuíam reserva obrigatória averbada. No Município de Piracicaba, onde realizou-se a presente pesquisa, não há grandes diferenças: das 2345 propriedades rurais, apenas 4 possuem reserva legal averbada, segundo o engenheiro do DEPRN responsável pelo atendimento ao público junto à Casa da Agricultura.

Ainda na tentativa de entender as constantes ameaças às florestas no Brasil e no mundo, buscou-se justificativas históricas. Segundo Perlin (1992, p.25 a 32) as florestas desempenharam importante papel no desenvolvimento das civilizações do passado. "As árvores foram o principal combustível e material de construção de quase todas as sociedades por mais de cinco mil anos, desde a ldade do Bronze até meados do século XIX". Por conseguinte, a abundância ou escassez de madeira modelou, em grande parte, a cultura, o perfil demográfico, a economia, a política e a tecnologia das sociedades antigas. Victor (1975, citado por MARTINS, 2000, p.2) constatou que: "a abertura de novos espaços (implicando no sacrifício da vegetação nativa) marcou profundamente a formação sócio-cultural do povo brasileiro, que passou a relacionar, compulsoriamente, a presença das matas ao atraso, e a sua eliminação ao progresso".

Outros autores, apontaram o distanciamento do homem em relação à Natureza, como principal causa de sua exploração predatória. Segundo Libório (1994, p.14), os povos modernos desenvolveram um sentimento de oposição à Natureza, brilhantemente discutido por Glacken (1974), que procura explicá-lo apresentando duas diferentes tradições no pensamento ocidental: a primeira é derivada do Antigo Testamento, especialmente do Gênesis, cap. 1, e a segunda tem como referência a filosofia dos séculos XVI e XVII. No Gênesis 1, 20-28, existe uma distinção entre os atos de Deus com relação a todas as formas de vida, com exceção do homem, e os atos de Deus com relação exclusivamente ao homem. No primeiro caso, toda vida deve aumentar e multiplicar-se; no segundo, o homem deve fazer o mesmo, mas assumindo a dominação sobre as demais formas de vida. Todavia, a autora acredita que muito maior peso nas relações de oposição, deve ser dado às reflexões filosóficas dos pensadores dos séculos XVI e XVII, dentre os quais são apontados Bacon, 
Descartes e Leibnitz, que viam no conhecimento a chave para o aperfeiçoamento do homem. Neste sentido, o curso da civilização deveria ser visto como uma evolução a partir de um tempo em que o homem estava sob a dependência da Natureza para uma situação inversa, em que ele conseguisse assumir o seu controle através do conhecimento adquirido e acumulado sobre ela. Sempre com o objetivo de melhorar sua condição humana e de humanizar o ambiente, o que, paralelamente, provocou uma relação de distanciamento. Esta proposta filosófica encontrou respostas cada vez mais amplas e eficazes, culminando com o conceito de progresso, conforme o adotado a partir do século XIX. Progresso que foi traduzido em termos de clara separação do homem em relação à natureza e que, por conseqüência, atingiu sua relação com a floresta.

Chaui (2000, p.1), ao comentar o livro "O Longo Amanhecer", de Celso Furtado, ilustra este entendimento de progresso no Brasil: "Depois de um longo período de estagnação, a economia brasileira do século 19 teve um momento de expansão e crescimento, decorrente das exportações de matérias-primas. $O$ excedente não foi investido em atividades produtivas e sim despendido no consumo das classes abastadas, e esse consumismo, com o qual os ricos marcavam a diferença social e o fosso que os separava do restante da população, recebeu o nome de progresso".

Nas palavras de Eco (1987, p.3), também é possível encontrar considerações a respeito do desejo de dominação humana sobre a Natureza: "O saber hermético exerceu considerável influência sobre Bacon, Copérnico, Kepler, Newton, e a ciência moderna quantitativa nasceu dialogando com o saber qualitativo do hermetismo. No fim das contas o modelo hermético sugeria a idéia de que a ordem do universo descrita pelo racionalismo grego poderia ser subvertida, e seria possível descobrir no universo novos nexos, novas relações que permitiriam ao homem agir sobre a natureza e alterar seu curso".

Diante da criticidade da situação de degradação florestal no Brasil, o Estado, enquanto objetivação institucional mais importante da sociedade, depara-se com o dever de enfrentar os problemas ambientais, sendo de sua competência exercer o controle dos diversos segmentos sociais como um todo, buscando seu bem-estar e seu desenvolvimento. Para isto, dispõe de variados mecanismos formais, como a norma legal, que deve regular, entre outros propósitos, as relações entre os cidadãos e entre 
estes e seu ambiente (Libório, 1994, p.4). Outro mecanismo pode ser reconhecido nas políticas ambientais, que visam a utilização sustentada dos recursos para proporcionar tanto a proteção dos processos ecológicos quanto a sobrevivência humana.

Entretanto, segundo Martins (2000, p.3), apenas um conjunto de leis, políticas e princípios de ação, não é suficiente para interromper o curso de depredação dos recursos florestais. $\mathrm{O}$ autor aponta a necessidade do Estado vincular as políticas a uma intervenção na realidade florestal. Ao estudar programas de recuperação de matas nos estados de São Paulo, Minas Gerais e Bahia, ele constata que os instrumentos econômicos mais utilizados (assistência técnica e doação de mudas), não têm sido suficientes para incentivar os proprietários a aderir a tais programas. Esta resistência pode ser resumida em duas causas: a primeira refere-se a oposição à obrigatoriedade legal de manter áreas protegidas em suas propriedades, que não poderão ser alteradas (no caso de áreas de preservação permanente), nem exploradas pelo corte raso (no caso de reserva legal). A segunda baseia-se na idéia de perda de patrimônio e redução da renda por parte dos produtores. "Tal resistência se fundamenta na perda econômica da manutenção destas áreas, tendo em vista o caráter restritivo do uso da terra que esta figura jurídica impõe" (Bacha, 1998, p.73, citado por Martins, 2000, p.3).

Malagodi (1999, p.185) aponta como causa de uma apatia, antipatia e até revolta entre proprietários rurais para com programas de reflorestamento, a baixa qualidade do processo comunicativo, obstruindo o afloramento de críticas e sugestões, que poderiam ser aproveitadas no aperfeiçoamento destes programas.

Diante das constatações feitas pelos autores acima - de que a simples existência de leis ou de políticas públicas não é suficiente para que efetivamente seja cessada a degradação às florestas no Brasil e recuperadas áreas degradadas - e, por outro lado, percebendo que a tomada de medidas se mostra cada vez mais necessária quando se pensa na importância das árvores, em qualidade de vida, preservação da biodiversidade, equilíbrio ecológico, etc..., emerge a seguinte questão: $O$ que poderia incentivar o plantio de árvores em propriedades rurais?

Martins (2000, p.74), cita os instrumentos econômicos, que poderiam transformar áreas protegidas em geradoras de renda. Tal idéia esbarra, atualmente, nas restrições do Código Florestal quanto à utilização econômica das áreas de preservação permanente. $O$ mesmo autor conclui que não se deve adotar estes 
instrumentos econômicos como única solução possível para a questão. "Há situações em que eles não se aplicam e outras em que serão desnecessários. Portanto, tais programas devem tentar identificar se há, e quais são, os fatores (problemas, dificuldades e aspirações) que determinam a resistência por parte dos produtores rurais em implantar florestas, possibilitando desenvolver estratégias que apontem para possíveis soluções".

Buscando facilitar a visualização dos problemas que impedem a incorporação do componente arbóreo por parte do proprietário rural e o desenvolvimento de estratégias, Martins (2000, p.76) sugere o agrupamento de fatores seguindo a classificação apresentada por Galjart em 1973: "sempre que se deseja introduzir alguma alteração ou inovação no sistema de produção do agricultor, e ela não se concretiza, o fator por trás desta resistência pode ser creditado à ignorância, à impotência e ao desinteresse. A ignorância se refere à falta do saber, à ausência de conhecimento por parte do produtor para adotar uma inovação ou mudança tecnológica. A incapacidade diz respeito a não poder, por razões financeiras ou outras razões, adotar uma inovação ou mudança, mesmo tendo o conhecimento de como fazê-lo. E o desinteresse refere-se ao fato do produtor saber o que deve ser feito, objetivamente poder fazê-lo, mas não o querer". Existe um conjunto de valores e atitudes a serem analisados.

Malagodi (1999, p.104), aponta para a imprescindibilidade da superação do mero enfoque punitivo na conservação e resgate da qualidade ambiental, devendo ser substituído por ações educacionais que, de forma coerente diagnostiquem o problema, prezem pela participação da comunidade (como um meio para o fortalecimento da população e para a construção do conhecimento), e cobrem a reestruturação e ação das instituições públicas nas áreas que são de sua responsabilidade.

Ferretti (2000, p.85), indica que diante da dificuldade de efetivar o plantio em propriedades particulares, os programas de reflorestamento deveriam se ater mais às ações de divulgação, sensibilização do produtor rural, e busca de alternativas que possibilitassem a presença do elemento arbóreo na propriedade agrícola, tanto como componente econômico quanto ambiental.

Libório (1994, p.328 a 330) verifica em sua pesquisa, que a interiorização dos valores ambientais e, por decorrência, daqueles que fundamentam a proteção do meio vegetal, ainda não foi concretizada. Para despertar este interesse e superar a relação 
de distanciamento entre o homem e a Natureza, tão evidente na atualidade, a autora afirma que é preciso ampliar o universo de informações e de conhecimento sobre a importância não só do patrimônio florestal como de toda natureza. "Aquele que detêm o conhecimento têm por obrigação irradiá-lo para criar canais de entendimento e de compreensão sobre a interdependência que existe entre o ser humano e o seu meio. Não se pode ignorar que este conhecimento, que implica idéias e juízos de valor, depende de estratégia mercadológica para ser assimilado pela opinião pública. A questão não se resolve ficando limitada aos círculos restritos de intelectuais que insistem em divulgar suas propostas através de linguagem hermética para o grande público. Tendo conhecimento claro da situação, as pessoas tendem a despertar sua afetividade e, com isso, passam a valorizar a paisagem. A valorização implica atribuirse a este recurso da natureza, as qualidades que o tornarão objeto de interesse e de proteção para toda a sociedade. Para tanto, os seus atributos precisam ser conhecidos e este conhecimento deve ser transmitido pelo processo de socialização, que vai, por sua vez, ser alimentado pela cultura ${ }^{1}$, que é quem detém os significados que vão dar a forma à conduta humana".

As sugestões apresentadas pelos autores acima, trazem grandes contribuições ao enfatizarem a importância de superar o enfoque meramente punitivo, de promover ações educacionais, de ampliar o processo comunicativo, de levar informações que despertem a afetividade e a valorização da Natureza, de discutir o potencial econômico e ambiental do elemento arbóreo, etc. $O$ presente estudo, porém, acredita que o diálogo pode ser uma boa maneira de enfrentar o problema, levando em consideração estas sugestões, como também, caminhando na direção da elaboração de uma proposta coletiva / participativa, construída em conjunto com os próprios proprietários rurais da região.

\footnotetext{
1 Uma das definições para o termo cultura, considerada moderna, precisa e abrangente, segundo Libório (pág. 132), é a de Geertz (1978). Este entende cultura como sendo "teias de significados". Não é um poder, algo ao qual podem ser atribuídos casualmente os acontecimentos sociais, os comportamentos, as instituições ou os processos; ela é um contexto, algo dentro do qual eles (os significados) podem ser descritos de forma inteligível. É um conjunto de mecanismos de controle para governar o comportamento.
} 


\title{
1.1 Justificativa
}

\begin{abstract}
"Pelo fato de se constituírem em elementos indispensáveis ao equilíbrio do meio ambiente, as florestas são consideradas, atualmente, como bens de interesse de toda a coletividade. É um patrimônio precioso, com funções múltiplas, que deve ser protegido por todos. Esta compreensão é decorrência dos profundos transtornos causados pelo desmatamento indiscriminado que vem acompanhando a trajetória humana em todas as regiões do planeta e que, no presente, alcança índices alarmantes, os quais devem ser revertidos" (Llibório, 1994, p.12).
\end{abstract}

As constatações elucidadas anteriormente, destacando a grande degradação que as florestas têm sofrido no Brasil e as grandes dificuldades que a sociedade enfrenta no sentido de proteger e recuperar áreas florestadas, inspiraram o presente trabalho. Tais barreiras, segundo diferentes autores, podem ser enfrentadas através da abertura ao diálogo, da troca de informações entre a comunidade científica e os agricultores, do planejamento participativo, da reflexão sobre a posição do ser humano em relação à natureza e do resgate da cidadania.

Deste modo, acredita-se ser de extrema importância a realização de um estudo considerando estas sugestões e, a partir delas, propor diretrizes para uma intervenção direcionada para a região em que está sendo efetuada a presente pesquisa. Vislumbrando, é claro, a proteção ambiental e o respeito a todos os seres envolvidos neste processo.

Buscou-se trilhar um caminho em direção à reflexão sobre os problemas ambientais mais diretamente envolvidos com as propriedades rurais do Município de Piracicaba, procurando fornecer às pessoas do campo, informações que servissem como instrumento de auxílio à tomada de decisão alicerçada em uma nova dimensão cultural e ética, com possível desencadeamento em ações no sentido de implementar o elemento arbóreo em suas propriedades. Para Libório (1994, p.328), a mudança de atitude ocorrerá na medida em que a auto-destruição coletiva venha representar uma ameaça iminente para cada um em particular e para o todo social. No entanto, o processo poderá ser revertido se e quando houver a ampliação do conhecimento, por via da cultura, o que irá interferir na percepção e na valorização das relações interativas do homem com a natureza.

O direito, enquanto complexo de leis ou normas que regem as relações entre os homens (Hauaiss, 1978, p. 278) e, fruto de lutas e conflitos da sociedade organizada (Aguiar, 1994, p.19), pode ser considerado uma valiosa ferramenta conservacionista. 
Deste modo, fornecer informações contextualizadas e propiciar o debate sobre as leis que protegem as florestas, bem como sobre as políticas públicas que buscam sua recuperação, também fizeram parte das metas deste trabalho.

Procurou-se identificar uma maneira na qual a Educação Ambiental e a Legislação Florestal pudessem ser associadas, de modo a contribuir para uma interiorização da preocupação ambiental e das responsabilidades de cada cidadão com a conservação de um ambiente ecologicamente equilibrado.

A importância deste enfoque, foi percebida durante as entrevistas e questionários realizados por Malagodi, Libório e Ferretti. Malagodi (1999, p.283), constatou que o programa de reflorestamento ciliar estudado por ele, gerou inúmeras resistências devido a fatos como os apontados por Ricardo e Romani: "os proprietários desconhecem a legislação; não estão conscientizados para a questão ambiental; colocam o interesse econômico acima da melhoria da qualidade de vida e, estão descapitalizados". Libório (1994, p.278 a 282), da mesma forma, averiguou entre seus entrevistados que, dentre as medidas apontadas para a eficácia da legislação florestal, em primeiro lugar aparece a Educação Ambiental ( $\cong 30 \%$ dos entrevistados); em segundo vem o fim da impunidade tanto para os infratores, quanto para as autoridades omissas (@28\%); logo após, aparece a ampliação dos recursos institucionais, a serem investidos em recursos humanos, materiais e técnicos, junto aos órgãos encarregados da fiscalização (27\%) e em menor escala, mas também importantes, seguem a divulgação e o aperfeiçoamento da Lei, para que esta seja melhor entendida e aplicada. As pesquisas realizadas por Ferretti (2000, p.85), indicaram que a questão legal, aliada ao temor da ação do DEPRN, da Polícia Florestal, Promotoria de Justiça e demais instituições ligadas ao setor ambiental, foi o motivo principal que levou os produtores a participarem do programa de fomento florestal. Por outro lado, a conservação dos recursos hídricos e do solo também motivaram muitos produtores para o plantio de espécies florestais. O autor constatou que, para se restaurar as áreas de matas ciliares não é suficiente apenas a instalação de viveiros e a produção de mudas de boa qualidade: "É preciso conhecer aquele que irá plantar e cuidar destas mudas. Somente recuperando o conhecimento florestal dos agricultores e proprietários de terras, buscando identificar o que os levou a retirar e eliminar as árvores e as florestas de suas terras, é que será possível tentar reverter a situação trazendo o elemento arbóreo novamente para dentro da propriedade rural e da cultura dos 
produtores rurais". Neste contexto, encaixa-se bem a definição de extensão rural presente na obra de Freire (1977): "Extensão rural, segundo Swanson \& Claar, compõe-se de duas dimensões: uma comunicacional e outra educacional, sendo um processo dinâmico que consiste em levar ao produtor rural informações úteis e relevantes (dimensão comunicacional) e ajudá-lo a adquirir conhecimentos, habilidades e atitudes para utilizar com eficiência essas informações (dimensão educacional)".

Para Libório (1994, p.38), a legislação florestal pode ser encarada como uma demonstração da preocupação das sociedades modernas com suas florestas, traduzida na edição de regras com maior ou menor rigor, dependendo da importância que a elas é atribuída. Deste modo, a associação entre o Direito e a Educação Ambiental, torna-se bastante desejável na busca da superação do distanciamento filosófico entre o homem e seu meio, bem como para possibilitar uma reflexão sobre o que é percebido, valorizado, conhecido e protegido na natureza e, dentro dela, na floresta. A autora conclui (p. 334): "É da essência do ser humano conhecer, valorar e querer. E, a partir daí, tomar suas decisões e fazer suas escolhas, dentro de uma escala de preferências, para o atendimento de suas necessidades e interesses. Somente através da assimilação do conhecimento da importância da floresta e outras formas vegetais para a vida humana e para a sobrevivência de nossa espécie é que será ampliada a percepção e realizada a valorização da paisagem florestal, dentro de uma cosmovisão que contemple o reequilíbrio das relações do homem com a natureza. Quando esta valorização ocorrer, todos, políticos e cidadãos comuns, crianças e adultos, homens e mulheres, liberais e assalariados, terão ultrapassado os limites da heteronímia moral e passarão a agir segundo as regras da cooperação, inspirados pelo princípio essencial de defesa do direito à vida, não apenas seu, mas de todos os seres vivos. A partir de então, poderá ser percebida a eficácia plena do Código Florestal e de outras leis que cuidam das relações do ser humano com a base de sua existência: a Natureza". 


\subsection{Objetivos}

A presente pesquisa teve como objetivo geral a contribuição para a geração de conhecimentos que possibilitassem a efetiva valorização, proteção e implantação de árvores e florestas pelo proprietário rural, na Região de Piracicaba / SP. Através da análise sobre a associação entre educação ambiental, legislação florestal e políticas públicas voltadas à incorporação do elemento arbóreo em propriedades rurais, buscava-se não apenas subsidiar plantios e legislações, mas também, instigar uma reflexão sobre a posição do ser humano em relação à Natureza, seus direitos e deveres.

Os objetivos específicos da pesquisa estão enumerados abaixo:

1. Realizar um estudo junto a proprietários rurais de uma microbacia hidrográfica de Piracicaba / SP, sobre a percepção que os mesmos possuem do elemento arbóreo e da legislação florestal;

2. Averiguar a necessidade de implantação de práticas educacionais e de fornecimento de informações contextualizadas, como forma de contribuir para a valorização do elemento arbóreo nas propriedades rurais, e para uma maior eficácia da legislação e dos programas de reflorestamento;

3. Potencializar um processo de intervenção educacional, buscando suprir algumas necessidades do público alvo, de modo a auxiliar na reflexão e no debate sobre a proteção ambiental e a cobertura florestal, bem como, sobre as legislações e políticas relacionadas com as mesmas;

4, Verificar os impactos de uma intervenção educacional e sua contribuição para uma interiorização da preocupação ambiental e das responsabilidades de cada cidadão com a conservação ambiental, resultando em ações;

5. Organizar sugestões para educadores, bem como para elaboradores e implementadores de Políticas Públicas voltadas à incorporação do elemento arbóreo e à recuperação, conservação e melhoria da cobertura vegetal nas propriedades rurais da região e apontar possíveis alterações na redação das leis, de modo a facilitar sua compreensão e execução por parte da sociedade. 


\section{REVISÃO DE LITERATURA}

\subsection{Um pouco de História - A Floresta e os Humanos}

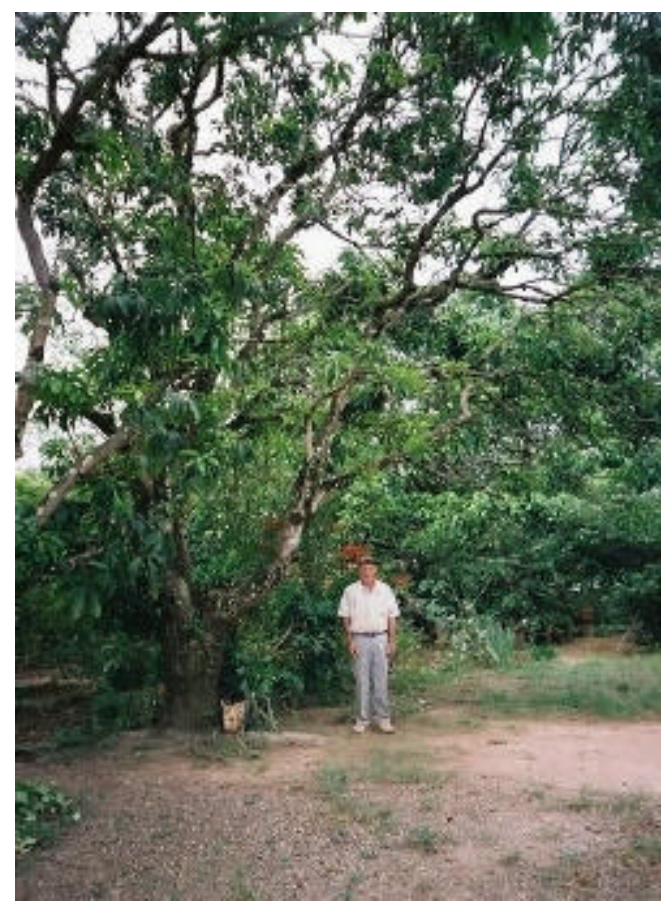

Figura 1 - Proprietário rural e a mangueira que alimenta a família por gerações.

A história das florestas confunde-se com a própria história da Civilização, afirma Jorge Boratto ${ }^{2}$ na apresentação do livro "História das Florestas", escrito por Perlin em 1992 (p. 15). Neste livro, Perlin (1992, p. 25) inicia seu relato declarando que antigos

${ }^{2}$ Ex-presidente da Sociedade Brasileira de Silvicultura. 
escritores já observavam que as florestas sempre retrocediam à medida que as civilizações se desenvolviam e cresciam. "Pode parecer audacioso defender um lugar central para a madeira na evolução da civilização. Porém, consideremos o seguinte: ao longo das eras, as árvores forneceram material para fazer fogo, cujo calor permitiu que a nossa espécie readaptasse o planeta para seu uso. Com o calor proveniente da queima de madeira, climas relativamente frios tornaram-se habitáveis; cereais não comestíveis foram transformados em importante fonte alimentícia; o barro pôde ser convertido em cerâmica, servindo para a fabricação de recipientes úteis para armazenamento de alimentos; as pessoas puderam extrair metais das rochas, revolucionando as ferramentas usadas na agricultura, embarcações e armamentos; e os construtores puderam fabricar materiais de construção duráveis, como tijolos, cimento, cal, argamassa e telhas para facilitar a moradia e a armazenagem de materiais. O carvão vegetal e a madeira também forneceram o calor necessário para fazer evaporar a água do mar e produzir sal; para fundir potassa e areia e fazer vidro; para assar grãos e fazer pão; e para cozer algumas misturas e transformá-las em produtos úteis, tais como tinta e sabão. $O$ transporte também seria impensável sem a madeira. Até o século XIX, todos os navios, desde o navio costeiro da ldade do Bronze até a fragata, foram construídos com madeira de lei (Os materiais alternativos para a construção de navios, tais como as bexigas e o junco, se mostraram frágeis demais para agüentar o peso de grandes cargas). Todas as carroças, carruagens e carretas também eram feitas originariamente de madeira. Nos Estados Unidos, os primeiros barcos a vapor e locomotivas utilizavam madeira como combustível. Embarcações de madeira eram presas a cais e ancoradouros feitos de madeira; carroças, carruagens e carretas de madeira atravessavam pontes de madeira; e os dormentes das ferrovias, é claro, eram de madeira. A madeira também era utilizada nas vigas que sustentavam os poços das minas e formavam o suporte para todo tipo de edificação. As rodas d'água e os moinhos de vento - que eram os principais meios de obtenção de força mecânica antes que a eletricidade começasse a ser utilizada - eram construídos com madeira. Os camponeses não podiam cultivar sem as ferramentas com cabos de madeira ou sem os arados de madeira; os soldados não podiam arremessar suas lanças ou atirar suas flechas sem as hastes de madeira, ou segurar suas armas se não fosse a coronha de madeira. $O$ que teriam feito os arqueiros se faltasse madeira para seus arcos; os cervejeiros e taberneiros sem madeira para seus barris e pipas; ou as 
indústrias de lã sem madeira para seus teares?". Perlin então conclui: "A madeira foi a base sobre a qual as sociedades antigas foram construídas".

Alguns exemplos de reconhecimento da importância da madeira para as civilizações, podem ser encontrados em declarações de personagens históricos: Platão, de acordo com Diógenes Laércio, escreveu que todas as artes e ofícios derivavam da mineração e da silvicultura. Cícero, o famoso estadista romano, explicou: "Nós cortamos árvores para cozinhar nossa comida (...), para fazer moradias (...), para minorar o calor e o frio (...) e também para construir embarcações que navegam em todas as direções para nos trazer as coisas necessárias para nossa subsistência". Ibn Khaldum, escrevendo no século XIV d.C., refletiu sobre o papel crucial que a madeira desempenhava no mundo islâmico: "Deus tornou todas as coisas criadas úteis para os homens, de modo a suprir suas demandas e necessidades. As árvores estão entre essas coisas. Elas possuem inumeráveis utilidades para todas as pessoas". Os venezianos consideravam as florestas como "os verdadeiros músculos da república". Os ingleses também reconheciam o papel crucial da madeira em suas vidas: Gabriel Plattes, escrevendo em 1639, observou que todas as ferramentas e instrumentos eram feitos de madeira e ferro. Porém, depois de avaliar a importância relativa dos dois materiais, ele preferiu a madeira ao ferro porque "sem a lenha não se pode obter o ferro" (Perlin, 1992, p. 29).

A utilização da madeira porém, não trouxe apenas benefícios para a humanidade. Seu uso desenfreado e sem planejamento adequado, ocasionou problemas em seu suprimento e, principalmente, uma grande degradação ambiental.

$\mathrm{Na}$ Messênia/Grécia, cerca de 1500 a.C., a madeira era muito utilizada em construções e para combustível para os trabalhos em bronze. Enquanto a economia se expandia e o número de habitantes crescia rapidamente, intensificava-se a derrubada das florestas para construções, espaço para moradias e expansão agrícola. Sem a devida cobertura florestal, o solo tornava-se mais vulnerável às forças erosivas da Natureza. Além disto, com a ausência das copas de árvores que pudessem fazer uma barreira entre as chuvas e o solo, toda a camada de terra fértil acabava por ser removida, como descreve Perlin (1992, p.64): "A destruição da cobertura de árvores também fez com que o solo perdesse sua capacidade de reter água depois dos temporais, o que resultou em enchentes nos ribeirões e nos rios. A transferência de solo das encostas para o fundo dos vales e para as regiões costeiras deixou muitos 
declives e montanhas com as rochas descobertas. O desmatamento total fez com que a matéria orgânica original do solo se perdesse e, em conseqüência disso, os solos gregos se mostraram deficientes em nitrogênio, que é um importante nutriente do solo. Essa deteriorização do solo, em especial nas encostas desmatadas, sem dúvida causou um declínio da produção agrícola. A perda da matéria orgânica exauriu sua capacidade de "alimentar" as plantas. À proporção que o solo empobrecia, o mesmo acontecia com as colheitas. Esta falta de nutrientes do solo, também serviu para fazer aumentar bastante a demanda de água para as plantações. Para piorar as coisas, pelo fato de nem a cobertura da floresta nem o entulho formado pelas folhas caídas terem sido preservados, os pingos das chuvas bombardeavam a superfície do solo com grande força, vedando-a, o que mais tarde levou à perda da capacidade de absorção de água - este fenômeno foi chamado de erosão de salpico. Uma vez que a água não podia penetrar no solo com tanta facilidade, o escoamento tornou-se um problema, pois acelerava a passagem da água através do ecossistema. Por isso, as condições de aridez prevaleciam, não porque as condições climáticas tivessem mudado no final do último período da idade do Bronze, mas porque o solo não conseguia mais reter a maior parte da água da chuva. Um volume menor de água penetrava no solo e recarregava os sistemas de reserva natural de água. $\mathrm{O}$ que poderia parecer uma mudança no clima era, na verdade, uma importante alteração na condição do solo como resultado da ação humana. Do mesmo modo que as florestas contribuíram para o sucesso da civilização miceniana, o contrário também ocorreu: as conseqüências do desmatamento contribuíram para o seu empobrecimento. Sem as reservas para sustentar esse grande número de pessoas, a população diminuiu rapidamente. Muitos tiveram que abandonar suas terras. Na busca por outras formas de sobrevivência houve agravamento da pobreza, guerras, exploração por províncias mais ricas e a adaptação a uma época de restrições - conformismo com uma situação de ausência de riquezas" (Perlin, 1992, p. 64 - 70).

Leão (2000), que também realizou um estudo sobre a história das florestas, também apresenta exemplos que demonstram os impactos da destruição das mesmas para antigas civilizações: "Em Chipre, aproximadamente em 1300-1200 a.C., o aumento das atividades metalúrgicas pressionou fortemente a estabilidade das florestas, pois o carvão vegetal era largamente utilizado. $O$ efeito cumulativo da devastação nessa escala foi sentido naquela pequena ilha mediterrânea, causando 
inúmeras mudanças na flora, fauna, solo e provocando desastres ambientais, como deslizamentos de terra, inundações, assoreamento dos rios, entre outros. Na Grécia, entre 700 a.C. e 200 a.C., o rápido crescimento populacional e o surgimento de algumas indústrias levaram à extinção das florestas costeiras da Ásia Menor. Com isso, os descendentes dos primeiros colonos foram obrigados a migrar para o interior, estabelecendo-se nas proximidades das bacias dos três maiores rios existentes no Sudoeste da Anatólia. As árvores ali existentes foram substituídas pelo plantio de trigo e, com o decorrer do tempo, esse cultivo provocou a erosão do solo ao longo dos rios. Suas margens ficaram mais vulneráveis, desbarrancavam facilmente e causavam o assoreamento do leito, trazendo graves prejuízos ambientais. A sedimentação na baía de Meandros transformou o mar - antes contíguo a Priena - numa área seca" (Leão, 2000, p. 113, 114).

Com o passar dos anos, as conseqüências da exploração desenfreada das florestas, intensificaram-se. Surgiram diversos problemas graves como o aquecimento global, o efeito estufa, o perigo da ausência de água, a má qualidade do ar, a extinção de espécies, etc. Apesar disto, observa-se que pouco tem sido feito para reverter este quadro. "O que é possível notar, é um aumento da extensão da dominação humana sobre a Terra", como afirma Lubchenco (1998, p. 4).

\subsection{A Educação Para Um Meio Ambiente Equilibrado}

\subsubsection{A Educação}

Para melhor compreensão do que é Educação Ambiental e quais as suas potenciais contribuições para o presente estudo, fez-se necessário realizar uma breve pesquisa sobre educação no sentido mais amplo da palavra.

Diz o Novo Dicionário Aurélio da Língua Portuguesa, que educação é "um processo de desenvolvimento da capacidade física, intelectual e moral da criança e do ser humano em geral, visando a sua melhor integração individual e social; (...); é o aperfeiçoamento de todas as faculdades humanas" (Ferreira, 1986, p.619). No mesmo 
dicionário, o verbo educar aparece com a seguinte definição: "transmitir conhecimento a; (...); cultivar o espírito" (p.619). Conceitos estes, que podem ir além de simplesmente informar. "dar informe ou parecer sobre; instruir, ensinar" (p.945).

Para Freire (1977, p.75 a 77), a educação se define como um processo constante de libertação do homem. "A educação como prática de liberdade, não é a transferência ou transmissão do saber nem da cultura; não é a extensão de conhecimentos técnicos; não é o ato de depositar informes ou fatos nos educando. É um esforço através do qual os homens decifram a si mesmos como homens".

Brandão, em seu livro "O que é Educação", observa que não há uma forma única nem um único modelo de educação. Ela pode ser tanto libertadora, quanto servir às classes dominantes. A educação é, porém, uma invenção humana, e pode ser reinventada. "Quando em alguma parte, setores populares da população começam a descobrir formas novas de luta e resistência, eles redescobrem também velhas e novas formas de 'atualizar' o seu saber, de torná-lo orgânico. Criam por sua conta e risco, ou com a ajuda de agentes-educadores eruditos, outras formas de associação, como os sindicatos, os movimentos populares, as associações de moradores. Estes grupos, que geram outros tipos de mestres entre as pessoas do povo, geram também outras situações vivas de aprendizagem popular. Eu não tenho dúvidas em afirmar que é entre as formas novas de participação popular, nas brechas da luta política, que, hoje em dia, surgem as experiências mais inovadoras de educação no Brasil. (...) A esperança está em acreditar que 0 ato humano de educar existe tanto no trabalho pedagógico que ensina na escola quanto no ato político que luta na rua por um outro tipo de escola, para um outro tipo de mundo" (Brandão, 1995, p.99 a 110).

Para Custódio (2000, p.39), a educação "torna-se cada vez mais essencial, portanto, indispensável ao pleno desenvolvimento humano, como pressuposto básico ao reconhecimento dos direitos, dos deveres, da probidade, das responsabilidades, em todos os setores, perante a sociedade presente e futura".

A educação deve considerar o cotidiano e as características particulares do público alvo. Neste sentido, Libâneo (1984, p.22) considera a educação como sendo "um processo interno, não externo; ela é parte das necessidades e interesses individuais necessários para a adaptação ao meio. A educação é a vida presente, é parte da própria experiência humana". 
Para Rubem Alves, "não existe coisa mais importante que educar. Pela educação o indivíduo se torna mais apto para viver: aprende a pensar e a resolver os problemas práticos da vida. Pela educação ele se torna mais sensível e mais rico interiormente, o que faz dele uma pessoa mais bonita, mais feliz e mais capaz de conviver com os outros. A maioria dos problemas da sociedade se resolveria se os indivíduos tivessem aprendido a pensar. Por não saber pensar tomamos as decisões políticas que não deveríamos tomar" (Alves, 2001). Deste modo, a educação sendo considerada como um processo de desenvolvimento da capacidade de pensamento, pode ser entendida como um valioso instrumento para solucionar problemas da sociedade.

Zuben (1979, p.193) aborda a educação e a existência, como dois fenômenos humanos dialeticamente vinculados. "A compreensão de um é sempre explicitada pela sua articulação com o outro. Não podemos, portanto, pretender interpretar o sentido do fenômeno educação sem, ao mesmo tempo, introduzir a questão do sentido da existência do sujeito como emergência de sua liberdade criadora. Sendo assim, é o esclarecimento da questão da educação o gerador dos elementos constitutivos da estrutura do sujeito como ser existente". O mesmo autor explica que: "a subjetividade ou a emergência do sujeito ao seu sentido de pessoa corporifica-se na constatação da própria finitude de sua existência encarnada. Esta finitude evoca ao sujeito a fragilidade de sua condição (isso o leva a querer afirmar-se). Por esta afirmação o sujeito adquire uma constância na história (duração) e uma extensão no espaço, é precisamente 0 ato de se engajar por uma causa. $O$ sujeito engaja-se no instante em que descobre o sentido de sua existência (dimensão crítico-questionadora) e quer manter-se em vida (que para o homem significa agir, trabalhar). $O$ engajamento prolonga a emergência do sujeito. O engajamento não é o ser do sujeito, mas a permanência conferida à sua identidade através da adesão de sua existência a uma causa. O eu quero vem confirmar o eu sou. Este se completa por aquele" (Zuben, 1979, p.215). Sendo assim, a educação servindo como fortalecedora do sujeito na medida em que possibilita seu engajamento a uma causa, confirmando sua identidade, tem na Educação Ambiental, uma importante aliada. Esta última, propõe como causa, a questão ambiental, e como produto de trabalho, o auto-conhecimento e conhecimento do Universo, o resgate de valores, sentimentos e tradições e o aumento da auto-estima do ser humano. 


\subsubsection{A Educação Ambiental}

Reigota (1994, p.10 e 58) afirma que a Educação Ambiental deve ser considerada como uma grande contribuição filosófica e metodológica à educação em geral. "Ela não está vinculada simplesmente à transmissão de conhecimento sobre a natureza, mas sim à possibilidade de ampliação da participação política das pessoas a medida em que ela reivindica e prepara os cidadãos para exigir justiça social, cidadania nacional e planetária, autogestão e ética nas relações sociais e com a Natureza. Nela está inserida a busca da consolidação da democracia, a solução dos problemas ambientais e uma melhor qualidade de vida para todos". O mesmo autor atenta ainda para a possibilidade da Educação Ambiental promover o diálogo entre gerações e culturas em busca destas cidadanias brasileira e planetária. "A Educação Ambiental deve orientar-se para a comunidade e procurar incentivar 0 indivíduo a participar ativamente da resolução dos problemas no seu contexto de realidade específicas. Os cidadãos do mundo, atuando nas suas comunidades, é a proposta traduzida na frase muito usada nos meios ambientalistas: pensamento global e ação local, ação global e pensamento local". Assim, mesmo que não consiga resolver todos os problemas ambientais planetários e até mesmo os locais de uma hora para outra, pois isto faz parte de um longo processo, a Educação Ambiental estará contribuindo para a formação de cidadãos conscientes dos seus direitos e deveres. E "tendo consciência e conhecimento da problemática global e atuando na sua comunidade, haverá uma mudança no sistema, que se não é de resultados imediatos, visíveis, também não será sem efeitos concretos", afirma Reigota (1994, p.12).

São diversos os objetivos para a Educação Ambiental encontrados na literatura:

Sorrentino (1995, p.16) avaliando as dimensões da questão ecológica abordada por autores como Pádua e Lago, 1984; Huber, 1985 e Guatarri, 1990, e as correntes traçadas pelo Grupo de Estudos do Centro de Educação Ambiental (OCA) da ESALQ/ USP, apresenta quatro grandes conjuntos de temas e objetivos com os quais se identificam diversas práticas de Educação Ambiental no país. São eles:

Biológicos: Proteger, conservar e preservar espécies, ecossistemas e o planeta como um todo; conservar a biodiversidade e o clima; detectar as causas da degradação da natureza, incluindo a espécie humana como parte da natureza; estabelecer as bases corretas para a conservação e utilização dos recursos naturais; 
Espirituais/culturais: Promover o auto-conhecimento e o conhecimento do Universo, através do resgate de valores, sentimentos e tradições e da re-construção de referências espaciais e temporais que possibilitem uma nova ética fundamentada em valores como verdade, amor, paz, integridade, diversidade cultural, felicidade e sabedoria, visão global e holística;

Políticos: Desenvolver uma cultura de procedimentos democráticos; estimular a cidadania e a participação popular; estimular a formação e aprimoramento de organizações, o diálogo na diversidade e a auto-gestão política;

Econômicos: Contribuir para a melhoria da qualidade de vida através da geração de empregos em atividades ambientais, não alienantes e não exploradoras do próximo. Caminhar em direção à auto-gestão do seu trabalho, dos seus recursos e dos seus conhecimentos, como indivíduos e como grupos/comunidades.

"Em síntese, estes quatro conjuntos de temas/objetivos poderiam ser reduzidos, na minha perspectiva, a um grande objetivo geral: Contribuir para a conservação da biodiversidade, para a auto-realização individual e comunitária e para a auto-gestão política e econômica, através de processos educativos que promovam a melhoria do meio ambiente e da qualidade de vida", afirma Sorrentino (1995).

Segundo Troppmair (1997, p.6), os objetivos da Educação Ambiental são muitos, destacando-se apenas 10 itens considerados por ele mais importantes:

1. Formar pessoas (crianças, jovens e adultos) conscientes da responsabilidade que têm para o Meio Ambiente;

2. Estimular atitudes racionais para o uso do Meio Ambiente, visando o ecodesenvolvimento, o desenvolvimento sustentável, ou seja, um desenvolvimento econômico e social que respeite as grandes Leis da Natureza como equilíbrio, recomposição, elasticidade, etc;

3. Observar, indagar e posteriormente entender o funcionamento do Sistema Natureza;

4. Conscientizar que a Terra é um sistema único e dinâmico, chamado GAIA (comparando-a a um ser vivo e associando seus diferentes ecossistemas a órgãos);

5. Deixar claro que pertubações ou destruições de parte da GAIA se refletem de forma negativa sobre TODO o sistema; 
6. Reconhecer que o homem é parte integrante e não dono (e muito menos exterminador) da Natureza;

7. Enfatizar a urgência do redirecionamento do uso dos recursos naturais e de mudança da mentalidade e dos padrões da Sociedade de Consumo. Incentivar os processos de reciclagem;

8. Preservar a biodiversidade entre as diversas espécies e dentro de uma mesma espécie pois não existem dois seres iguais;

9. Manter e, sempre que possível, melhorar a qualidade ambiental e de vida;

10. Formar cidadãos conscientes de suas responsabilidades e que sejam atuantes na sociedade.

Para Brito (2000, p. 32), a Educação Ambiental tem um papel fundamental, não só na possibilidade de percepção do ser humano em seu meio, construindo a sua cidadania, mas na possibilidade de valorizar emoções e sentimentos de amor, carinho, desejos vitais de ver o outro feliz e, assim, ser feliz também.

Pode-se detectar a emergência da questão ambiental ${ }^{3}$ e mais especificamente da Educação Ambiental, através de um breve histórico de eventos sobre o tema.

Em 1968, cientistas de países desenvolvidos se reuniram em Roma e concluíram sobre a necessidade urgente de se buscar meios para a conservação dos recursos naturais e controlar o crescimento da população, além de se investir numa mudança radical na mentalidade de consumo e procriação. Os participantes deste encontro, conhecido como "Clube de Roma", observaram que "o homem deve examinar a si próprio, seus objetivos e valores. O ponto essencial da questão não é somente a sobrevivência da espécie humana, porém, ainda mais, a sua possibilidade de sobreviver sem cair em estado inútil de existência" (Limites do Crescimento, 1978, citado por Reigota, 1994, p.14).

Em 1972, a Organização das Nações Unidas realizou em Estocolmo, a Primeira conferência Mundial de Meio Ambiente Humano. Uma resolução importante desta conferência foi a de que se deve educar o cidadão para a solução dos problemas ambientais. Para Reigota (1994, p.15), surgiu neste momento o que se convencionou chamar de Educação Ambiental.

\footnotetext{
${ }^{3}$ Mais profundamente estudada por Acot (1990), Lago e Pádua (1985), McCormick (1992), Guattari (1991) e Sirkis (1987).
} 
Em 1975, em Belgrado na luguslávia, foi realizada uma reunião de especialistas em educação, biologia, geografia e história, entre outros, em que se definiu os objetivos da Educação Ambiental, publicados na "Carta de Belgrado". Dentre estes objetivos, destaca-se: "Desenvolver um cidadão consciente do ambiente total, preocupado com os problemas associados a esse ambiente e que tenha 0 conhecimento, as atitudes, motivações, envolvimento e habilidades para trabalhar individual e coletivamente em busca de soluções para resolver os problemas atuais e prevenir os futuros".

No ano de 1977, em Tibilissi, na Geórgia (ex-URSS), realizou-se o Primeiro congresso Mundial de Educação Ambiental. Nesta Conferência Intergovernamental de Educação Ambiental foram recomendados alguns princípios que até hoje são referência para quem pratica Educação Ambiental (MEC, 1998):

1. Considerar o meio ambiente em sua totalidade: em seus aspectos natural, tecnológico, social, econômico, político, histórico, cultural, técnico, moral, ético e estético;

2. Construir um processo permanente e contínuo, durante todas as formas do ensino formal, desde o início da educação infantil;

3. Aplicar um enfoque interdisciplinar, aproveitando o conteúdo específico de cada área, de modo a se conseguir uma perspectiva global da questão ambiental;

4. Examinar as principais questões ambientais do ponto de vista local, regional, nacional e internacional;

5. Concentrar-se nas questões ambientais atuais e naquelas que podem surgir, levando-se em conta a perspectiva histórica;

6. Insistir no valor e na necessidade da cooperação local, nacional e internacional, para prevenir os problemas ambientais;

7. Considerar explicitamente os problemas ambientais nos planos de desenvolvimento e crescimento;

8. Promover a participação dos alunos na organização de todas as suas experiências de aprendizagem, dando-Ihes a oportunidade de tomar decisões e aceitar suas conseqüências;

9. Estabelecer para os alunos de todas as idades uma relação entre a sensibilização ao meio ambiente e a aquisição de conhecimentos, habilidades e atitudes, para resolver problemas e clarificar valores, procurando, principalmente, 
sensibilizar os mais jovens para os problemas ambientais existentes na sua própria comunidade;

10. Ajudar os alunos a descobrirem os sintomas e as causas reais dos problemas ambientais;

11. Ressaltar a complexidade dos problemas ambientais (...), a necessidade de se desenvolver o sentido crítico, e as atitudes necessárias para resolvê-los.

12. Utilizar diversos ambientes com a finalidade educativa, e uma ampla gama de métodos para transmitir e adquirir conhecimento sobre o meio ambiente, ressaltando principalmente as atividades práticas e as experiências pessoais.

Em 1987, na então União Soviética, ocorreu o Segundo Congresso de Educação Ambiental, na qual foram reafirmadas as propostas de Tbilisi. Segundo Genebaldo Freire Dias (MEC, 1998), uma das conclusões apresentadas nesta conferência, foi que "os objetivos da Educação Ambiental não podem ser definidos sem que se levem em conta as realidades sociais, econômicas e ecológicas de cada sociedade ou os objetivos determinados para o seu desenvolvimento; deve-se considerar que alguns objetivos da Educação Ambiental são comuns à comunidade internacional".

Nesse mesmo período, a primeira ministra norueguesa, Gro-Brundtland, realizava reuniões em várias cidades do mundo, cujas conclusões foram publicadas em várias línguas no livro chamado O Nosso Futuro Comum, também conhecido como Relatório Brundtland. É a partir desse livro que o conceito de desenvolvimento sustentável se torna mais conhecido. Aí também se enfatiza a importância da Educação Ambiental para a solução de problemas (Reigota, 1994, p.17).

Em 1992, no Estado do Rio de Janeiro / Brasil, acontece a Rio-92. Nesta Conferência das Nações Unidas sobre Meio Ambiente e Desenvolvimento, o conceito de desenvolvimento sustentável é bastante discutido. É traçada a agenda 21 , documento assinado por 170 países com o objetivo de guiar ações do governo e de toda a comunidade que procuram desenvolvimento sem com isto destruir o meio ambiente. Em seu capítulo 36, trata do Fomento da Educação, Capacitação e Conscientização. Destacam-se, segundo Sorrentino (1995, p.22), os seguintes pontos:

- Promover o desenvolvimento sustentável e aumentar a capacidade das populações para abordar questões ambientais e de desenvolvimento; 
- Adquirir consciência, valores e atitudes técnicas e comportamentos ecológicos e éticos em consonância com o desenvolvimento sustentável e que favoreçam a participação pública efetiva no processo de adoção de decisões;

- Ocupar-se da dinâmica do meio físico/biológico, sócio-econômico e desenvolvimento humano (que poderia compreender o desenvolvimento espiritual), integrando-se em todas as disciplinas e utilizando métodos acadêmicos e não-acadêmicos e meios efetivos de comunicação;

- Dar preferência à responsabilidade e ao controle local para as atividades tendentes a fomentar a consciência do público;

- Adquirir conhecimentos que ajudem a conseguir empregos e a participar em atividades relativas ao meio ambiente e ao desenvolvimento.

O Brasil, além de ser um dos países signatários da Agenda 21, possui leis que asseguram a presença da Educação Ambiental em todos os níveis de ensino - como na própria Constituição Federal de 1988 em seu Artigo 225, ou na Lei 9.795 de 27/04/99 que dispõe sobre a Política Nacional de Educação Ambiental ${ }^{4}$.

\subsection{As contribuições do Direito}

Segundo Gonzalez (2000, p.3), ao contrário do que pensam muitos juristas, o Direito não possui vida própria, desvinculada das condições culturais, econômicas e sociais do seu tempo. Desde os primórdios, quando os seres humanos viviam em grupos e passavam a formar pequenas tribos ou comunidades mais elaboradas, logo percebiam a necessidade de um ordenamento jurídico mínimo, que disciplinasse suas condutas e que possibilitasse uma vida social onde não predominasse a guerra de todos contra todos.

No princípio, o direito não era escrito, e sim, consuetudinário (Stuchka, 1972, citado por Gonzalez, 2000, p. 155), ou seja, fundado nos costumes (Ferreira, 1986, p. 461). "Entre revoluções e retrocessos das civilizações e com o descobrimento da

4 Pede-se aprofundar conhecimentos sobre as interfaces entre educação, ambientalismo e educação ambiental com a leitura de autores como Novo (1985), Sorrentino (1995), McCormick (1992), Delors /199?/, Santos (1997), Morin (2000). 
escrita, o homem pôde registrar seus pensamentos e procedimentos e logo passou também a construir normas jurídicas escritas, a fim de que estas pudessem ser impostas, compreendidas e aceitas. Na marcha dos processos civilizatórios, os ordenamentos jurídicos surgiram, ora em decorrência da contribuição de homens sábios e prudentes, ora em decorrência de pressões e exigências populares, ora pela imposição de reis e imperadores que os impunham sob a égide de seu poderio bélico, político ou religioso" (Gonzalez, 2000, p. 4).

$\mathrm{Na}$ Grécia Antiga, o direito iniciou-se com a tragédia ${ }^{5}$. Esta, influenciou diretamente a formação do pensamento jurídico ocidental, embora poucos acreditem que foi por exemplo um poeta grego, Simonedes, quem criou os princípios do direito grego: "viver honestamente, não lesar ao próximo e dar a cada um o que é seu" ("luris praecepta sunt haec: honeste vivere, alterum nom laedere, suum cuique tribuere"). A maneira como se consolidou a justiça grega, influenciou em muitos aspectos na formação do ordenamento jurídico romano e hoje integra a realidade e os fundamentos do direito contemporâneo e da justiça ocidental. Antes disso, antes do advento da civilização e da tragédia grega, os julgamentos e a distribuição de justiça estavam ligados a rituais bárbaros, onde o direito confundia-se com preceitos religiosos e morais (Gonzalez, 2000, p. 14 e 15).

Para Manzine-Covre (1995, p.29), o Estado de Direito, o governo pelas leis, foi uma conquista histórica da humanidade e deve ser irreversível. "As leis são instrumentos importantes para fazer valer nossos direitos, ainda que por meio de inúmeras pressões sociais. E, quanto mais a sociedade evolui, mais os homens serão capazes de lidar com os conflitos pela palavra, conforme o espírito da pólis grega".

No decorrer da evolução do direito, os gregos deram origem também, ao Direito Natural Clássico. Gonzalez (2000, p. 20) afirma que a lição deixada por estes pensadores, é que "a lei justa pode e deve ser extraída da própria natureza. A natureza ensina aos homens o que é certo e o que é errado, o que é bom e o que não é. Como na natureza tudo está em constante evolução e mudança, também o Direito Natural não é estático mas sim mutável". O direito Natural passa então a ser definido por

${ }^{5}$ A tragédia é aqui entendida como poema dramático, cujo assunto é na maioria das vezes tomado como lenda ou história, e que põe em cena personagens ilustres, em ação destinada a promover o terror ou piedade pelo espetáculo das paixões humanas e das desgraças que desencadeiam (Houaiss, 1979, p. 840). 
alguns filósofos como um sistema de princípios que deriva da natureza das coisas e que deve ser aplicado à sociedade para a distribuição da justiça e para a elaboração das leis.

O Direito Ambiental possui convergências com o Direito Natural na medida em que o primeiro, ganha respeito e se fortalece ao reafirmar o conceito de que a Natureza pode e deve ditar o que necessita de proteção.

Um bom exemplo da utilização da Lei para transcrever o que na verdade a própria Natureza indica necessitar ser protegido, é o Código Florestal de 1965. Este foi encaminhado ao presidente da república para aprovação de seu anteprojeto de lei em 1965, acompanhado de uma carta de "Exposição de Motivos". Nela, o então Ministro da Agricultura declarava estar encaminhando um projeto visando encontrar uma solução adequada para o problema florestal brasileiro, cujo progressivo agravamento exigia adoção de medidas capazes de impedir a transformação de vastas áreas do território Nacional em verdadeiros desertos: "A Constituição Federal condiciona o uso da propriedade ao bem-estar social. Com base neste princípio, as leis estabelecem gabaritos, áreas de ventilação, tetos de aluguéis e uma série de restrições ao uso da propriedade, sem qualquer indenização aos proprietários. Ora, se o Poder Público pode criar restrições ao uso da propriedade, que dizer daquelas que são impostas pela própria natureza, antes da existência daquele Poder? Assim como certas matas seguram pedras que ameaçam rolar, outras protegem fontes que poderiam secar, outras conservam o calado de um rio que poderia deixar de ser navegável, etc. São restrições impostas pela própria Natureza ao uso da terra, ditadas pelo bem-estar social. (...) A função protetora da floresta não é restrição indenizável, mas decorrência da própria natureza que preparou terras mais úteis e outras menos. É como se uma lei declarasse que as terras roxas podem produzir café. A lei que considera de preservação permanente as matas nas margens de um rio está apenas dizendo, mutatis mutandi, que um pantanal não é terreno adequado para plantar café. (...) $\mathrm{O}$ dilema é este: ou impõe-se a todos os donos de terras defenderem à sua custa a produtividade do solo, contra a erosão terrível e crescente, ou cruzam-se os braços, ante a incapacidade, pela pobreza do Poder Público na maioria dos Estados do Brasil, para deter a transformação do País num deserto, em que as estações se alternem entre inundações e secas, devoradoras de todo o esforço humano". 
Embora exista clara convergência entre o Direito Natural e o Direito Ambiental, o próprio texto do exemplo acima, aponta para a necessidade de leis escritas e da tomada de atitudes imediatas que garantam a proteção ambiental, indicando neste sentido, uma postura mais positivista.

O Brasil tem adotado a postura de elaborar leis diversificadas no intuito de defender os direitos dos cidadãos e a qualidade de vida das futuras gerações. Como ilustração deste cenário de leis, os quadros abaixo apresentam uma síntese da legislação da educação ambiental e algumas das muitas leis ambientais do país.

\begin{tabular}{|c|l|}
\hline ANO & \multicolumn{1}{c|}{ DISPOSITIVO LEGAL } \\
\hline 1981 & $\begin{array}{l}\text { Lei 6938 - Lei Nacional de Meio Ambiente que dispõe sobre a Política } \\
\text { Nacional de Meio Ambiente. }\end{array}$ \\
\hline 1986 & $\begin{array}{l}\text { Indicação CFE 10/86 - é a primeira indicação para incluir a Educação } \\
\text { Ambiental nos currículos escolares. }\end{array}$ \\
\hline 1987 & Parecer 226/87- aprova a indicação 10/86. \\
\hline 1988 & Constituição Federal. \\
\hline 1990 & Decreto 99.270/90 - regulamenta a Lei 6938/81. \\
\hline 1991 & $\begin{array}{l}\text { Portaria 678 - MEC - determina a inclusão da Educação Ambiental na } \\
\text { educação Escolar. }\end{array}$ \\
\hline 1996 & Lei 9.394 - Diretrizes e Bases da Educação (LDB). \\
\hline 1999 & Lei 9.795 - Política Nacional de Educação Ambiental. \\
\hline 2000 & Plano Nacional de Educação (Projeto de Lei). \\
\hline
\end{tabular}

Quadro 1 - Síntese da Legislação da Educação Ambiental.

Fonte: Leite (2001, p.224). 


\begin{tabular}{|c|c|}
\hline ANO & DISPOSITIVO LEGAL \\
\hline 1965 & LEI N 4.771 - Institui o Código Florestal Brasileiro. \\
\hline 1981 & LEI N 6.938 - Dispõe sobre a Política Nacional do Meio Ambiente. \\
\hline 1985 & $\begin{array}{l}\text { LEI No } 7.347 \text { - Disciplina Ação Civil Pública de Responsabilidade por } \\
\text { Danos Causados ao Meio Ambiente, (...). }\end{array}$ \\
\hline 1986 & $\begin{array}{l}\text { RESOLUÇÃO CONAMA № 001/86 - Dispõe sobre o Licenciamento } \\
\text { Ambiental. }\end{array}$ \\
\hline 1986 & $\begin{array}{l}\text { RESOLUÇĀO CONAMA № 020/86 - Dispõe sobre a Classificação das } \\
\text { Águas. }\end{array}$ \\
\hline 1987 & RESOLUÇĀO CONAMA № 009/87 - Dispõe sobre a Audiência Pública. \\
\hline 1988 & $\begin{array}{l}\text { CONSTITUIÇÄO FEDERAL DE } 1988 \text { - Em especial o artigo 225, trata } \\
\text { do Meio Ambiente. }\end{array}$ \\
\hline 1990 & $\begin{array}{l}\text { RESOLUÇÃO CONAMA № } 003 / 90 \text { - Dispõe sobre os Padrões de } \\
\text { Qualidade do Ar. }\end{array}$ \\
\hline 1990 & $\begin{array}{l}\text { RESOLUÇĀO CONAMA № 008/90 - Dispõe sobre Limites Máximos de } \\
\text { Emissão de Poluentes. }\end{array}$ \\
\hline 1993 & DECRETO FEDERAL 750 - Regulamenta Exploração da Mata Atlântica. \\
\hline 1997 & $\begin{array}{l}\text { LEI N } 9.433 \text { - Institui a Política Nacional de Recursos Hídricos e cria o } \\
\text { Sistema Nacional de Gerenciamento de Recursos Hídricos. }\end{array}$ \\
\hline 1998 & LEI N 9.605 - Institui a chamada Lei de Crimes Ambientais. \\
\hline 2000 & $\begin{array}{l}\text { LEl N N } 9.985 \text { - Dispõe sobre o Sistema Nacional de Unidades de } \\
\text { Conservação da Natureza. }\end{array}$ \\
\hline 2000 & LEI N 9.984 - Cria a Agência Nacional de Águas - ANA. \\
\hline
\end{tabular}

Quadro 2 - Importantes Leis Ambientais.

\subsubsection{O Direito Ambiental}

O Direito Ambiental Brasileiro, apresenta como finalidade principal a defesa do meio ambiente como bem de interesse coletivo. Neste sentido, a Constituição Federal de 1988, em seu Artigo 225, afirma que: "Todos têm direito ao meio ambiente ecologicamente equilibrado, bem de uso comum do povo e essencial à sadia qualidade de vida, impondo-se ao poder público e à coletividade o dever de defendê-lo e preservá-lo para as presentes e futuras gerações". Também o Código Florestal Brasileiro, instituído pela Lei nำ.771 de 15 de setembro de 1965, demonstra em seu artigo primeiro este objetivo: "As florestas existentes no território nacional e as demais formas de vegetação, reconhecidas de utilidade às terras que revestem, são bens de interesse comum a todos os habitantes do País, exercendo-se os direitos de 
propriedade, com as limitações que a legislação em geral e especialmente esta Lei estabelecem".

Para Machado (1999, p.7), o artigo 1ํ da Lei 4.771/65, além de antecipar-se à noção de interesse difuso quando conceituou meio ambiente como bem de uso comum do povo, trouxe outro avanço ao dizer que "as ações ou omissões contrárias às disposições deste Código na utilização e exploração das florestas são consideradas uso nocivo da propriedade" (Art. 1ํㅗㄹ parágrafo único). O mesmo autor complementa: "O interesse comum na existência e no uso adequado das florestas está ligado, com forte vínculo, à função social da propriedade". Essa função não é faculdade, mas uma obrigação indeclinável como se vê na Constituição Federal de 1988, Art. 5º, XXIII "a propriedade atenderá a sua função social" e Art. 170, que diz que a ordem econômica tem por fim assegurar a todos existência digna, observados, dentre outros, os princípios da função social da propriedade e da defesa do meio ambiente. Assim, a ausência de florestas ou a destruição das mesmas pode configurar um atentado à função social e ecológica da propriedade. "O ser humano, por mais inteligente e mais criativo que seja, não pode viver sem as outras espécies vegetais e animais. Conscientes estamos que sem florestas não haverá água, não haverá fertilidade do solo, enfim, sem florestas não viveremos" (Machado, 1999, p.8).

Além das leis propriamente ditas, que fazem com que a legislação ambiental brasileira seja considerada uma das mais avançadas do mundo, vale destacar alguns princípios gerais do Direito Ambiental - Princípio do Acesso Eqüitativo aos Recursos Naturais; Princípio Usuário-pagador e Poluidor-pagador; Princípio da Precaução; Princípio da Prevenção; Princípio da Reparação; Princípio da Informação; Princípio da Participação - que segundo Machado (2000, p.43) "estão formando e orientando a geração e a implementação do Direito Ambiental".

Não se pode negar, porém, que o Direito Ambiental no Brasil apresenta alguns problemas. Principalmente no que diz respeito à sua aplicabilidade, divulgação, compreensão e aceitação popular. Muitas vezes, as normas são consideradas exageradas ou são desconhecidas para a maioria da população.

A existência de leis em grande número, a complexidade dos seus termos e as constantes alterações que as leis ambientais tem sofrido, somando-se ao despreparo e à dificuldade de acesso e interpretação que a população em geral possui em relação 
às normas escritas, fazem com que o Direito Ambiental seja ainda muito pouco conhecido e respeitado pela grande maioria dos brasileiros.

Deste modo, o exercício da cidadania, o reconhecimento das responsabilidades individuais e coletivas e a participação popular promovidos pela Educação Ambiental, podem auxiliar o Direito Ambiental a cumprir sua função primordial: proteger os interesses da coletividade, garantindo a preservação e conservação da Natureza e dos recursos necessários para uma boa qualidade de vida para as presentes e futuras gerações.

\subsubsection{A Participação Política}

Brito (2000, p. 29) afirma que a educação ambiental tem um papel importante a cumprir na relação entre os diferentes grupos sociais, tentando, através da participação popular, buscar na história local, perceber, sentir, modificar, criar formas de ações conjuntas que possibilitem uma melhoria da qualidade de vida e do meio ambiente. Para a autora, o "estímulo à participação deve propiciar uma sintonia entre os desejos individuais e os anseios coletivos, propiciando a cada pessoa envolvida incluir-se em ações que estejam em sinergia com o todo, ainda que pontuais". Esta participação é compreendida não apenas como participação efetiva em termos de ações concretas, mas também como participação afetiva e participação política, sedo que esta última, caracteriza-se pela compreensão do indivíduo da sua ação na coletividade, da cidadania local e planetária, em que a necessidade organizacional perpassa a necessidade de discussão dos problemas individuais tratados como do coletivo e os do coletivo tratados como pertencentes a cada indivíduo da comunidade. (Brito, 2000, p. 30).

Para Dallari (1984, p.10) "política é a conjunção das ações de indivíduos e grupos humanos, dirigindo-as a um fim comum", portanto a participação política implica numa organização de grupos sociais em torno de problemas comuns, da coletividade. O mesmo autor afirma ainda: "A participação política é uma necessidade da natureza humana" (Dallari, p.89).

Sung (2000, p.80) acredita que só através da participação da sociedade civil na política do país, poderá ocorrer uma transformação no sistema burocrático e serão 
corrigidos excessos de formalização que acabam por dificultar o acesso e a contribuição da população na tomada de decisões.

$\mathrm{Na}$ definição de Ribeiro (1998, p.11) política pode ser entendida "como um processo através do qual interesses são transformados em objetivos e os objetivos são conduzidos à formulação e tomada de decisões efetivas". O mesmo autor acrescenta: "A política não é apenas uma coisa que envolve discursos, promessas, eleições e, como se diz freqüentemente, 'muita sujeira'. Não é uma coisa distinta de nós. É a condução de nossa própria existência coletiva, com reflexos imediatos sobre nossa existência individual, nossa prosperidade ou pobreza, nossa educação ou falta de educação, nossa felicidade ou infelicidade. (...) Se não gostamos do comportamento dos políticos e do funcionamento do sistema e não fazemos nada quanto a isso, estamos sendo políticos: estamos contribuindo para a perpetuação de uma situação política indesejável ou inaceitável. Se queremos fazer alguma coisa para melhorar a situação, também estamos sendo políticos, pois a única via de ação possível, nesse caso, é a Política" (Ribeiro, 1998, p.20 e 21).

Como visto, a participação política está diretamente ligada à tomada de decisões e atitudes, o que converge com um dos principais objetivos da educação, que é fornecer condições para que as pessoas possam fazer escolhas conscientes e se sintam motivadas a agirem em busca de uma vida melhor. Este enfretamento político, faz parte do exercício da cidadania: "Só existe cidadania se houver a prática da reivindicação, da apropriação de espaços, da luta para fazer valer os direitos das pessoas, para a construção de uma sociedade melhor (Manzine-Covre, 1995, p.10). A mesma autora, na medida em que aborda os direitos dos cidadãos, também faz referência às leis: "A lei entra como um valioso instrumento para o cidadão que souber utilizá-la, ajudá-la e construí-la da melhor forma possível para que a humanidade seja capaz de lidar com conflitos pela palavra. (...) Os cidadãos devem fazer uso público da própria razão e estarem num processo contínuo de crítica às leis ". (Manzine-Covre, 1995, p.29).

Deste modo, com o exercício da cidadania, com a educação e com a participação política, busca-se também, garantir a informação, o debate, a coerência e a eficácia da legislação florestal, contribuindo assim, para a proteção e implementação de florestas no país. 


\section{METODOLOGIA}

\subsection{Fundamentação Teórica}

A presente pesquisa trata-se de um estudo exploratório que visa subsidiar uma intervenção educacional. Dialoga com os seguintes métodos e técnicas de pesquisa: estudo de caso; pesquisa-ação e pesquisa participante; entrevistas; questionários; observação; pesquisa qualitativa e quantitativa; e triangulação. Utilizando-se de método idiossincrático ("maneira própria de ver, sentir, reagir, de cada indivíduo", Ferreira, 1993, p.292), foram percorridos caminhos e realizadas análises bastante singulares, buscando enquanto pesquisa, promover o relato fiel e a sugestão de procedimentos para futuros pesquisadores, levando-se em consideração as experiências vivenciadas.

Esta peculiaridade do caminho seguido, teve como objetivo principal colher informações que permitissem compreender melhor a realidade do proprietário rural e sua forma de perceber as questões ligadas à árvore (passando pela visão utilitarista, estética, legal e/ou conservacionista).

Para um melhor entendimento dos fundamentos teóricos das áreas de conhecimento aqui enunciadas, segue uma breve consideração sobre as mesmas.

\subsubsection{Estudo de Caso}

Para Stake (1994, p.236) o Estudo de Caso não é uma escolha metodológica, mas a escolha de um objeto a ser estudado de diversas formas. "O nome Estudo de 
Caso, visa chamar atenção para o que pode ser especificamente aprendido de um único caso", afirma o mesmo autor.

Atualmente, a comunidade científica tem se interessado mais em estudar casos envolvendo fenômenos ou populações, do que um único indivíduo. As pesquisas têm se concentrado em entender a complexidade destes grupos e este processo acaba por envolver o aprendizado sobre o caso, e a geração de conhecimento. A proposta do estudo de caso não é produzir uma teoria (embora isto possa acontecer em alguns casos), mas realizar um estudo contextualizado, aprofundado e detalhado sobre o caso em questão.

\subsubsection{Pesquisa-Ação e Pesquisa Participante}

Brito (2000, p. 45), fundamentada em Thiollent (1985), afirma que o termo pesquisa participante está contido na pesquisa-ação. Este último, é mais amplo pois apresenta um compromisso com a transformação do contexto social, político, ecológico e cultural de uma comunidade, no que tange à melhoria da qualidade de vida e do meio ambiente.

Segundo Thiollent, (1986, p.9) este tipo de pesquisa está voltado para a "descrição de situações concretas e para a intervenção ou a ação orientada em função da resolução de problemas efetivamente detectados nas coletividades consideradas".

Deste modo, pode-se dizer que o presente trabalho buscou dialogar com a pesquisa-ação e com a pesquisas participante na medida em que, desde o seu início, propunha-se a auxiliar os participantes a dialogarem e a refletirem sobre a melhoria de sua qualidade de vida. Procurou-se suprir algumas necessidades de informação apontadas pelos próprios pesquisados, rever a relação dos mesmos com o elemento arbóreo de suas propriedades, apontar para a potencialidade de diversidade de cultivos (saindo do trivial da região: o plantio de cana-de-açúcar) e promover debates a respeito da importância da proteção do meio ambiente. 


\subsubsection{Entrevistas e Questionários}

Para Denzin \& Lincoln (1994, p.353), a entrevista é uma das melhores ferramentas metodológicas de pesquisa qualitativa. "A entrevista é uma conversa, a arte de fazer perguntas e ouvir respostas". Ela não perde o seu valor por não ser neutra. "Seu método é influenciado por características pessoais do entrevistador, incluindo raça, classe, etnia e gênero". Ann Oakley (1981), socióloga britânica citada por Denzin \& Lincoln (1994, p.353), afirma ter encontrado um maior número de contradições em pesquisas científicas positivistas, que requerem objetividade e neutralidade, do que em pesquisas que utilizam entrevistas abertas, com envolvimento emocional e relações baseadas na verdade entre entrevistadores e sujeitos.

Cruz Neto (1996, p.57) afirma que através da entrevista, o pesquisador busca obter informes contidos na fala dos atores sociais. Para ele, "ela não significa uma conversa despretensiosa e neutra, uma vez que se insere como meio de coleta dos fatos relatados pelos atores, enquanto sujeitos-objeto da pesquisa, que vivenciam uma determinada realidade que está sendo focalizada. Suas formas de realização podem ser de natureza individual e/ou coletiva". O mesmo autor acrescenta que através desse procedimento, pode-se obter dados objetivos e subjetivos. "Os primeiros podem ser também obtidos através de fontes secundárias, tais como censos, estatísticas e outras formas de registros. Em contrapartida, o segundo tipo de dado se relaciona aos valores, às atitudes e às opiniões dos sujeitos entrevistados".

Segundo Sorrentino (1995, p.8), com as anotações feitas durante as entrevistas realizadas numa determinada pesquisa, procura-se construir o discurso do pesquisador fundamentado no discurso dos entrevistados. O mesmo autor, citando Geertz (1978, p.19), acrescenta: "O que chamamos de nossos dados são realmente nossa própria construção das construções de outras pessoas (...). A análise é, portanto, escolher entre as estruturas de significação (...) e determinar sua base social e sua importância".

Fontana \& Frey (1994, p.361) afirmam que questionar é muito mais complicado do que possa parecer à primeira vista. "Palavras faladas ou escritas carregam sempre um resíduo de ambigüidade, não importando o quão cuidadosamente as questões sejam elaboradas e reportadas ou as respostas sejam codificadas. Todavia, este é um dos caminhos mais comuns e mais poderosos utilizados para tentar entender os seres humanos". Os mesmos autores diferenciam entrevistas estruturadas e não- 
estruturadas caracterizando a primeira como sendo uma situação em que um entrevistador utiliza um questionário com perguntas pré-estabelecidas e um número limitado de respostas; e a segunda (não-estruturada) como um tipo de entrevista que apresenta muito mais flexibilidade, dando aos questionamentos, uma natureza qualitativa 6 . "A interação entre entrevistador e entrevistado, embora seja impensável em pesquisas sociológicas tradicionais, é a principal essência da pesquisa nãoestruturada", afirma Spradley (1979), citado por Fontana \& Frey (1994, p.366).

Para Cruz Neto (1996, p.58), a diferença entre entrevista estruturada e semiestruturada, corresponde ao fato de serem mais ou menos dirigidas. Assim, torna-se possível trabalhar com questionário aberto ou não-estruturado, onde o informante aborda livremente o tema proposto; bem como trabalhar com os estruturados, que pressupõem perguntas previamente formuladas. "Há formas, no entanto, que articulam estas duas modalidades, caracterizando-se como entrevistas semi-estruturadas" (Cruz Neto, 1996, p.2).

A opção feita na presente pesquisa, foi a de utilizar questionários préestabelecidos, porém com perguntas abertas, de modo a possibilitar ao entrevistado fazer comentários diversificados. Pode-se dizer que o método adotado caracteriza-se pela utilização de questionário semi-estruturado.

\subsubsection{Observação}

"A observação de uma situação social é mais uma importante maneira de se coletar informações do mundo social”, afirmam Denzin e Lincoln (1994, p.354).

Para Adler \& Adler (1994, p.377), "a observação não é apenas uma das primeiras e triviais formas de pesquisa, mas é a preferida a ser usada em conjunto com outras técnicas, tais como pesquisa participativa, planejamento experimental e entrevistas. O pesquisador deve escolher entre se colocar no meio do grupo que quer observar, ou apenas observá-lo à distância. Um dos problemas apontados é que o observador é forçado a confiar mais exclusivamente em sua própria percepção, dando

${ }^{6}$ Os autores citam como exemplo,o método de Malinowski, que prega a imersão do pesquisador na cultura nativa estudada, tirando suas conclusões interagindo com os nativos ou simplesmente "estando lá". 
espaço a uma interpretação subjetiva (Denzin, 1989; Schatzman \& Strauss, 1973; Webb et al, 1966). Este é um dos fatores pelo qual a observação é raramente utilizada como única técnica de coleta de dados em pesquisas científicas, mesmo naquelas exclusivamente qualitativas".

Schwartz \& Schwartz, citados por Haguette (1992, p. 69), concebem a observação participante não só como um instrumento de captação de dados mas, também, como instrumento de modificação do meio pesquisado, ou seja, de mudança social.

Na presente pesquisa, as observações foram efetuadas durante a participação, como ouvinte, em eventos envolvendo proprietários rurais promovidos pela prefeitura e pela Casa da Agricultura de Piracicaba/SP, e pela observação de comportamentos, situações peculiares e características das propriedades durante a fase de visitas e entrevistas no campo. Estes dados não foram objeto de sistematização, mas propiciaram uma maior aproximação e conhecimento sobre a realidade estudada. Após as visitas e eventos, foram anotadas as principais e mais marcantes situações vivenciadas.

\subsubsection{Pesquisa Qualitativa e Quantitativa}

Publicações feitas nas décadas de 1920 e 1930 na "Escola de Chicago", apresentaram grandes contribuições às pesquisas sociológicas ao afirmarem a importância da pesquisa qualitativa. No mesmo período, o método qualitativo de trabalho foi largamente utilizado também em pesquisas antropológicas por diversos autores como Boas, Mead, Benedict, Baterson, Evans-Pritchard, Radcliffe-Brown e Malinowski (Denzin \& Lincoln, 1994, p.1). No entanto, até os dias de hoje, não é fácil definir o que seria uma pesquisa qualitativa, isto porque, seu significado varia de acordo com o momento histórico, afirmam Denzin \& Lincoln (1994, p.1). Na tentativa de apresentar uma definição genérica, os mesmos autores indicam que a pesquisa qualitativa "enfoca métodos variados, envolvendo uma interpretação e uma maneira naturalística de abordagem. Isto significa que pesquisadores qualitativos estudam as coisas em seu conjunto natural, num esforço de fazer sentido, ou interpretar fenômenos, de acordo com os significados que as pessoas atribuem a eles". Existe 
uma multiplicidade de metodologias para a pesquisa qualitativa, que pode ser vista como uma "bricolagem", ou seja, um agrupamento de práticas utilizadas para solucionar um problema numa situação concreta ${ }^{7}$.

Com o intuito de diferenciar a pesquisa qualitativa da pesquisa quantitativa, os autores Denzin e Lincoln (1994, p.4) afirmam que a palavra "qualitativa" enfatiza processos e significados que não são rigorosamente examinados ou mensurados em termos de quantidade, soma, intensidade ou freqüência, enquanto que, estudos quantitativos priorizam a mensuração e análise de relações causais entre variáveis, e não entre processos.

Haguette (1992, p.63) afirma que o método qualitativo fornece uma compreensão profunda de certos fenômenos sociais apoiados no pressuposto da maior relevância do aspecto subjetivo da ação social face à configuração das estruturas societais, seja a incapacidade da estatística de dar conta dos fenômenos complexos e dos fenômenos únicos. Para a autora, os métodos quantitativos supõem uma população de objetos de observação comparável entre si e os métodos qualitativos enfatizam as especificidades de um fenômeno em termos de suas origens e de sua razão de ser.

Patton (1980, p.11), citado por Brito (2000), afirma que a metodologia de pesquisa qualitativa contribui para as comunidades desenvolverem programas que auxiliem no entendimento da realidade, no afloramento de conflitos e na busca de soluções para os problemas.

Para Minayo (1996, p. 28), freqüentemente, a dicotomia entre métodos qualitativos e quantitativos que se estabelece na prática, de um lado, deixa à margem relevâncias e dados que não podem ser contidos em números, e de outro lado, às vezes contempla apenas os significados subjetivos, omitindo a realidade estruturada. Neste sentido, a busca pelo equilíbrio entre os dois métodos pode trazer grandes contribuições para o ramo da pesquisa científica. A mesma autora cita Mannheim, considerado o fundador da sociologia do conhecimento, dizendo que o mesmo opõe-se ao positivismo que tenta tornar mensuráveis e discerníveis sem ambigüidade todos os

\footnotetext{
${ }^{7}$ A bricolagem muda e toma nova forma conforme novas ferramentas, métodos e técnicas são somadas ao 'quebra-cabeças'. "A escolha das ferramentas a serrem usadas ou qual técnica de pesquisa utilizar, não é feita com antecedência. Esta escolha de práticas de pesquisa depende da pergunta feita, e esta questão depende do contexto", afirma Nelson et al. (1992), citados por Denzin \& Lincoln (1994, p.2).
} 
fatos sociais, pois há certos termos tão carregados de valores que só um participante do sistema social estudado pode compreendê-lo. Mannheim chama atenção para a participação do sociólogo como observador da realidade que pesquisa e diz-nos que isso pode significar o sacrifício do que às vezes se considera como necessária "neutralidade e objetividade científica". Para ele, "o desprezo pelos elementos qualitativos e a completa restrição da vontade não constitui objetividade e sim negação da qualidade essencial do objeto".

Minayo (1996) acrescenta ainda que "a fenomenologia, defende a idéia de que as realidades sociais são construídas nos significados e através deles, e só podem ser identificadas na medida em que se mergulha na linguagem significativa da interação social. A linguagem, as práticas e as coisas são inseparáveis na abordagem fenomenológica. Ela enfatiza os significados gerados na interação social. (...) Esta abordagem, na medida em que acredita que a realidade vai mais além dos fenômenos percebidos pelos nossos sentidos, trabalha com dados qualitativos que trazem para o interior da análise, o subjetivo e o objetivo, os atores sociais e o próprio sistema de valores do cientista, os fatos e seus significados, a ordem e os conflitos. (...) A questão da objetividade é então colocada em outro nível. Dada a especificidade das ciências sociais, a objetividade não é realizável. Mas é possível a objetivação que inclui o rigor no uso de instrumental teórico e técnico adequado, num processo interminável e necessário de atingir a realidade. $O$ que se pode ter dos fenômenos sociais, é menos um retrato e mais uma pintura conforme a imagem usada por Demo $\left(1985\right.$, p.73) ${ }^{8}$. (...) Portanto, a objetivação, isto é, o processo de construção que reconhece a complexidade do objeto das ciências sociais, seus parâmetros e suas especificidades é o critério interno mais importante de cientificidade. É preciso aceitar que o sujeito das ciências sociais não é neutro ou então se elimina o sujeito no processo de conhecimento. Da mesma forma, o "objeto" dentro dessas ciências é também sujeito e interage permanentemente com o investigador. A "objetivação" nos leva a repudiar o discurso ingênuo ou malicioso da neutralidade, mas nos diz que é necessário buscar formas de reduzir a incursão excessiva dos juízos de valor na pesquisa. Os métodos e técnicas de preparação do objeto de estudo, de coleta e tratamento dos dados ajudam o pesquisador, de um lado a ter uma visão crítica de seu trabalho e, de outro, de agir

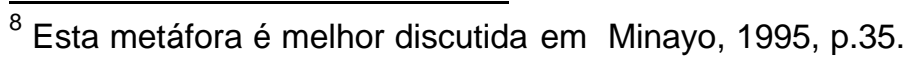


com instrumentos que lhe indicam elaborações mais objetivadas. Conforme adverte Demo, no labor de investigação, a prática não substitui a teoria e vice-versa (1985, p. 75)" (Minayo, 1996, p.34).

Muitas são também as críticas que podem ser feitas à abordagem qualitativa. Vêm dos mais diferentes pontos e atacando flancos variados. As mais freqüentes seriam: a) o empirismo de que são acometidos muitos pesquisadores que passam a considerar ciência a própria descrição dos fatos que lhes são fornecidos pelos atores sociais. Dele estão imbuídos aqueles que consideram a versão das pessoas sobre os fatos como a própria verdade. Já Durkheim chamava atenção para este problema (1978, 27); b) a ênfase na descrição dos fenômenos em detrimento da análise dos fatos; c) o envolvimento do pesquisador com seus valores, emoções e visão de mundo na análise da realidade; d) a dificuldade em si de trabalhar com "estados mentais". A críticas em relação à abordagem qualitativa na verdade são constatações das falhas e das dificuldades na construção do conhecimento. Mas as "ciências sociais não podem deixar de estar permanentemente engajadas num discurso com seu próprio objeto de estudo: um discurso, no qual tanto o investigador quanto o assunto compartilham dos mesmos recursos" (Giddens, 1978, p.234).

\subsubsection{Triangulação}

Para facilitar a análise dos resultados, optou-se por utilizar a técnica de triangulação ${ }^{9}$. Sua escolha, reflete uma tentativa de assegurar o entendimento mais aprofundado do estudo em questão. Os autores Denzin \& Lincoln (1994, p.2), acreditam que a realidade objetiva nunca pode ser capturada, porém, a triangulação apresenta-se como uma alternativa de validação dos resultados encontrados. "A combinação de métodos múltiplos, dados empíricos, perspectivas e observações em um único estudo é melhor entendido, então, como uma estratégia que soma rigor, abrangência, e profundidade a qualquer investigação". Segundo Flick (1992), citado

${ }^{9}$ Segundo o Manual de Técnicas para o Diagnóstico (Participativo) Rápido Rural, a triangulação consiste no uso de várias e diferentes fontes e meios de coleta de informação (Witeside, 1998, p.6). 
por Stake (1994, p.241), a triangulação tem sido genericamente considerada como um processo de utilização de percepções múltiplas, com o intuito de esclarecer significados, verificar repetições de uma observação ou interpretação. Sabendo-se que uma observação ou interpretação não pode se repetir exatamente da mesma forma, a triangulação serve também para clarear significados através da identificação de diferentes maneiras de se observar um fenômeno.

Para Huberman \& Miles (1994, p.438), a triangulação surge também para promover a convergência entre diferentes pesquisas e diferentes teorias.

Patton (1990), citado por Diniz (1999), define triangulação como a combinação de metodologias no estudo do mesmo fenômeno ou programa de pesquisa. Pode incluir abordagens qualitativas ou quantitativas. O mesmo autor, citando Smith \& Kleine (1986), detalha a triangulação de dados qualitativos, afirmando que a mesma pode contemplar a comparação de dados de observação com dados de entrevistas; o confronto entre o que as pessoas dizem em público e o que dizem em privado; a variação do que elas dizem sobre a mesma coisa ao longo do tempo; e a comparação das perspectivas destas pessoas a partir de diferentes pontos de vista, dos vários envolvidos e de pessoas de fora do programa.

Janesick (1994, p.209) apresenta as quatro modalidades básicas de triangulação identificadas por Denzin $(1978)^{10}$, e sugere a adição de uma nova categoria: a triangulação intedisciplinar, que segundo o autor, surge para evitar que uma área de conhecimento se sobreponha a outra durante o processo de triangulação.

Patton (1980, p.330), citado por Sorrentino (1995, p.90), declara que da mesma forma que na triangulação de métodos, a triangulação de fontes de dados raramente leva a um quadro único e totalmente consistente: "É melhor não se esperar que tudo chegue ao mesmo ponto. A questão é estudar e entender quando e porque existem diferença. $O$ fato de que dados de observação produzem resultados diferentes dos dados obtidos através de entrevistas não significa que um ou ambos os tipos são válidos, apesar de que pode ser este o caso. É mais provável que diferentes tipos de

\footnotetext{
${ }^{10}$ Os quatro tipos de triangulação apresentados por Denzin (1978) sâo: triangulação de dados que consiste na utilização de múltiplas estratégias de amostragem; a triangulação de pesquisadores - baseada no uso de diversos pesquisadores ou avaliadores; a triangulação de teorias - que utiliza variadas perspectivas de interpretação para um único tipo de dado; e a triangulação metodológica - que consiste na utilização de múltiplos métodos para estudar um único problema.
} 
dados capturem coisas diferentes e desta forma cabe ao analista entender as razões destas diferenças. Ao mesmo tempo, a consistência de dados provenientes de fontes diversas, além de explicações razoáveis para as diferenças entre eles contribuem significativamente para a credibilidade da descoberta".

\subsection{Escolha do público alvo e da área de estudo}

Refletindo a respeito do público alvo, optou-se pela abordagem junto a proprietários rurais, visto que, em geral, são eles quem decidem as culturas ${ }^{11}$, as regiões de plantio, as áreas a serem preservadas, etc, em suas propriedades e conhecem bem as realidades e possibilidades do setor. São eles também, que optam por participar ou não de programas de reflorestamento e respondem pelas irregularidades legais que possam existir em suas propriedades.

A escolha da área de estudo - a Microbacia do Tamandupá, pertencente à SubBacia do Rio Corumbataí e à Bacia do Rio Piracicaba - foi efetuada considerando-se cinco dos critérios para escolha de bacias hidrográficas prioritárias, presentes nas seguintes publicações: "Terra Amiga: Programa Estadual de Microbacias Hidrográficas" (CATI, 1998) e "Relatório do Projeto Corumbataí - Convênio IPEF / SEMAE" (IPEF / SEMAE, 1999). São eles: existência de mananciais destinados ao abastecimento humano; ocorrência de intensa degradação ambiental; boa receptividade por parte do município e dos produtores; proximidade de nascentes e notória pressão legal para a recuperação florestal.

\footnotetext{
$\overline{11}$ As decisões também podem ser influenciadas pelo mercado (oferta e procura). Entende-se porém, que ainda assim, cabe ao proprietário rural tomar a decisão final.
} 


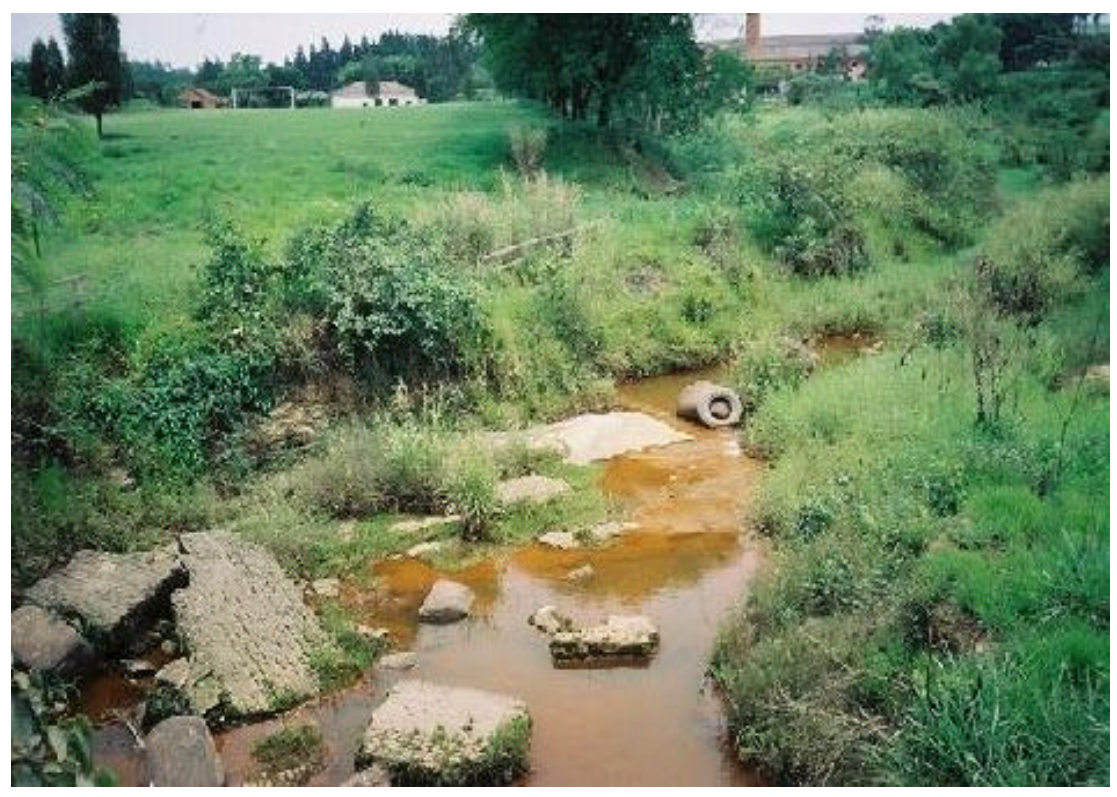

Figura 2 - Córrego Tamandupá, bastante degradado.

A legislação ambiental mais recente, reconhece o termo "bacia hidrográfica" e também demonstra a importância de utilizá-lo como unidades de estudo e gestão, pois, segundo a Lei № 9.433/97, que institui a Política Nacional de Recursos Hídricos: "a bacia hidrográfica é a unidade territorial para implementação da Política Nacional de Recursos Hídricos e atuação do Sistema Nacional de Gerenciamento de Recursos Hídricos". A Lei No 9.984/00, que cria a Agência Nacional de Águas, considera os estudos feitos pelos Comitês de Bacias Hidrográficas e os mecanismos quantitativos sugeridos por eles, para a determinação dos valores para a cobrança pelo uso da água. A Medida Provisória No 2166/01, utiliza-se do termo "microbacia", para disciplinar sobre a compensação de área de Reserva Legal.

Como pretendia-se realizar o trabalho na região de Piracicaba devido a sua carência em intervenções como a proposta neste trabalho, optou-se pela Bacia do Rio Piracicaba. Dentro desta Bacia, a Sub-Bacia do Rio Corumbataí foi escolhida por possuir características correspondentes aos critérios mencionados anteriormente: apresenta grande importância no abastecimento de água de municípios como Analândia, Corumbataí, Rio Claro e Piracicaba, e apesar disto, encontra-se bastante degradada em vários trechos, com quadros de poluição, assoreamentos, mortalidade de peixes, ausência de mata ciliar, etc. (Jornal de Piracicaba, 11/05/2000). Além disto, 
tem sido objeto de estudo e trabalho de diversas instituições que se esforçam no sentido de conservar sua capacidade de geração de recursos hídricos, o que pode contribuir para o aumento de receptividade por parte dos municípios. Também tem sofrido pressões legais para sua adequação ambiental, principalmente depois da promulgação da lei de Crimes Ambientais - Lei 9.605, de 1998. Esta Sub-Bacia, porém, apresenta grande dimensão, sendo que apenas o Rio Corumbataí possui 136,5 quilômetros de comprimento e atravessa oito municípios: Analândia, Corumbataí, Itirapina, Ipeúna, Charqueada, Rio Claro, Santa Gertrudes e Piracicaba), o que dificultaria um trabalho mais aprofundado em toda a sua extensão. Por isto, optou-se pelo trabalho em uma área menor, uma microbacia denominada Tamandupá (Figura 3).

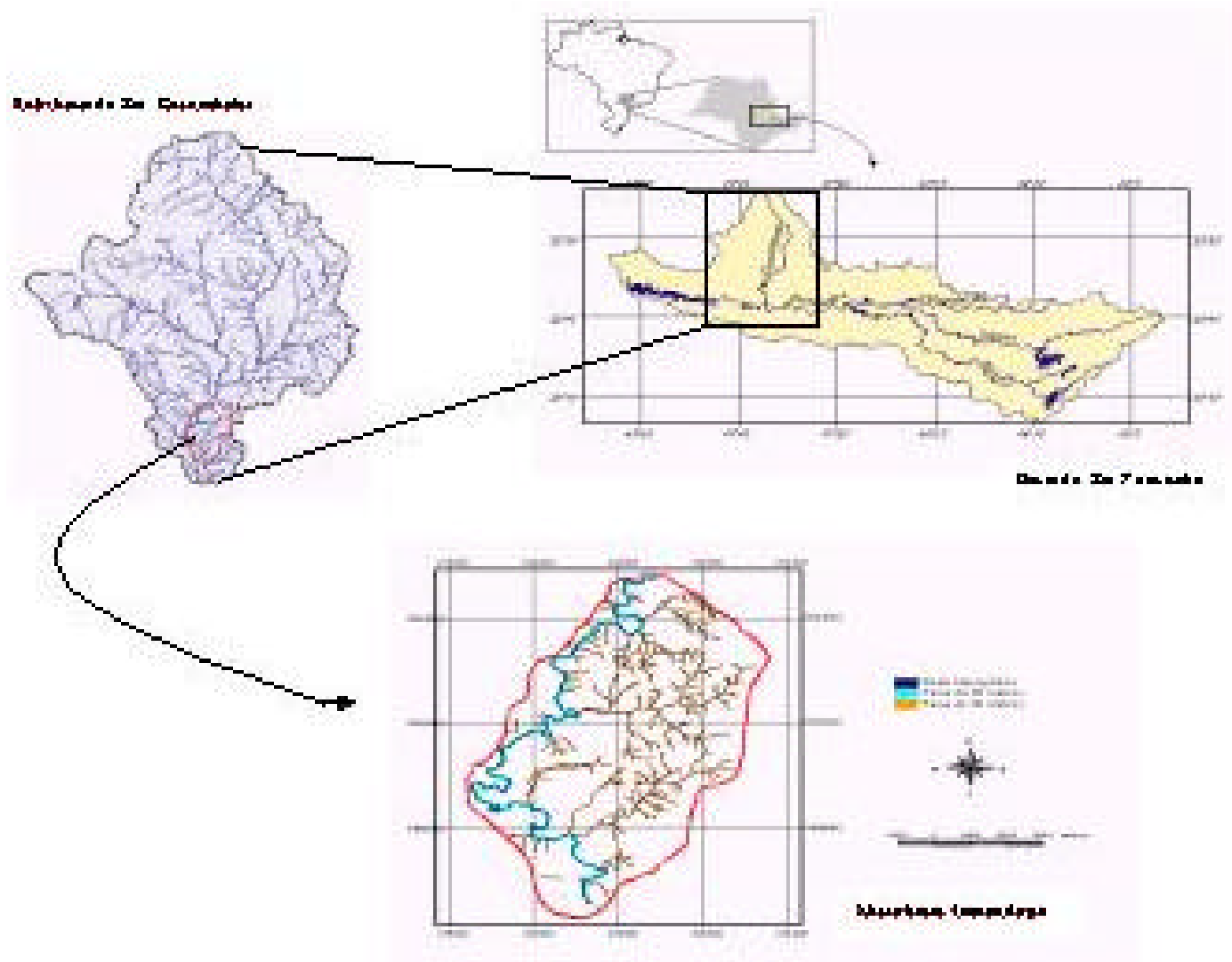

Figura 3 - Localização da Microbacia Tamandupá.

Mapas adaptados do Projeto Corumbataí (IPEF/SEMAE, 2001) e do Site do Projeto PiraCena. 
A região denominada Microbacia do Tamandupá está localizada na porção final da bacia do rio Corumbataí entre as coordenadas UTM 749400 e 750500 de latitude Norte e 221800 e 229000 de latitude oeste, totalizando uma área de aproximadamente 5000 ha, ocupados principalmente por culturas de cana-de-açúcar (51\%), cobertura florestal pouco alterada (23\%) e pastagens (17\%) (Lima \& Zákia, 2000). Esta microbacia possui especial importância dentro da bacia do Rio Corumbataí, pois nesta região é feita a captação de água que abastece o município de Piracicaba. Atualmente, $100 \%$ da água destinada à área urbana de Piracicaba, é captada da bacia do Rio Corumbataí (Merli, 1999, p.5). Além disto, a região é relativamente próxima ao centro urbano de Piracicaba, o que facilita o acesso às propriedades rurais e reduz os custos da pesquisa.

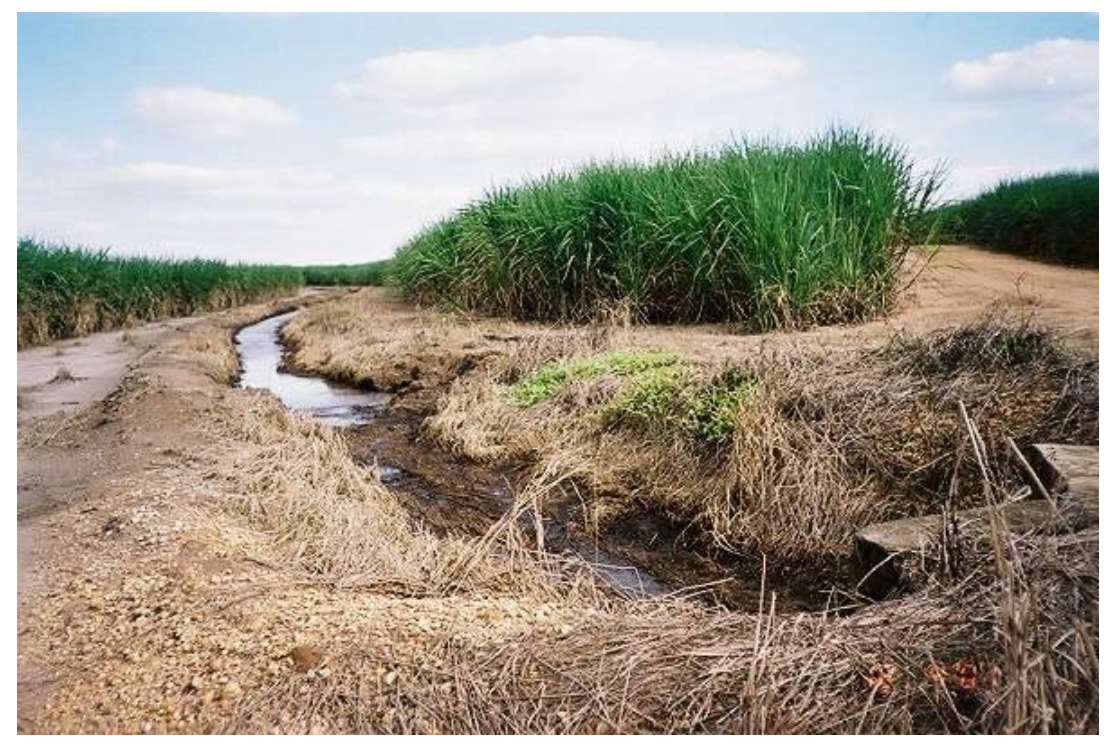

Figura 4 - Cana-de-açúcar, paisagem comum na região.

Vale ainda ressaltar, que a região onde se encontra a microbacia Tamandupá, foi também escolhida como área piloto do Projeto Corumbataí - Convênio IPEF / SEMAE. Deste modo, diversos levantamentos como tipo de solo, cobertura vegetal, declividade, etc., estão sendo realizados na região, o que auxiliará na contextualização de informações disponibilizadas ao proprietários rurais, bem como, poderá contribuir para a viabilização de projetos de reflorestamento caso exista interesse por parte dos proprietários. 


\subsection{Diagnóstico de Percepção}

Nesta etapa de trabalho, foi efetuado um estudo buscando verificar a repetição na microbacia Tamandupá, de algumas das constatações apresentadas nas teses de Libório (1994), Malagodi (1999) e Ferretti (2000). A metodologia utilizada por eles, orientou a realização de um diagnóstico de percepção e valorização do elemento arbóreo e do grau de conhecimento da legislação florestal e dos princípios que regem a proteção das florestas, por parte dos proprietários rurais desta região. Foi possível então, avaliar as possibilidades de serem acatadas as sugestões apontadas por estes autores.

A pesquisa de Libório (1994) apresentou uma analise das relações entre a eficácia do Código Florestal brasileiro e a valorização da paisagem florestal no Sudoeste Paulista. Foram obtidos dados pessoais, aspectos perceptivos, valorativos e atitudinais, utilizando como instrumento de medida um questionário contendo questões abertas e fechadas, aplicado por terceiros. Seguiu-se um encadeamento lógico de questões mais amplas e abstratas no início do questionário, até chegar a situações concretas e cotidianas.

Malagodi (1999), abordou as relações entre extensão rural e educação ambiental, refletindo sobre um programa de reflorestamento ciliar realizado em uma microbacia do Rio Capivari / SP. Seu trabalho apresentou depoimentos de proprietários rurais, que inspiraram o autor a avaliar os caminhos percorridos entre as motivações e as ações. Foram realizadas entrevistas pessoalmente, utilizando roteiro de questões dando maior enfoque ao tema 'reflorestamento ciliar', porém o autor procurou verificar também o modo como os proprietários rurais se relacionavam com o elemento arbóreo.

Ferretti (2000) avaliou o Programa de Fomento da CESP de Porto Primavera, levantando junto aos proprietários rurais os motivos de participação ou desistência do Programa, as opiniões e sugestões para o mesmo. Enviou um formulário com questões de múltipla escolha pelo correio.

Utilizando-se as conclusões e experiências apresentadas por estes três autores, optou-se pelo emprego de entrevistas. Estas foram orientadas por um questionário (Anexo A) compactando aspectos levantados nos três estudos citados, através da adaptação das questões consideradas mais relevantes. 
Durante a elaboração do questionário, contou-se com o auxílio da responsável pela Casa da Agricultura do Município de Piracicaba, que realizou um trabalho de adequação de linguagem do questionário, chegando a um modelo mais simplificado (Anexo B). No entanto, optou-se por aplicar o questionário do Anexo A devido ao fato de se tratar de perguntas feitas pelos entrevistadores diretamente para os entrevistados, sendo que os aplicadores é que eram incumbidos de ler as perguntas e anotar suas respostas. Deste modo, as questões deveriam estar em linguagem que propiciasse melhor entendimento por aqueles que estavam questionando, para que pudessem explicar as perguntas para os entrevistados. Durante este processo, as sugestões vindas da Casa da Agricultura foram muito úteis para que os entrevistadores realizassem alterações de linguagem no momento de efetuar as perguntas para os proprietários rurais.

Foram aplicados 4 questionários em áreas contíguas à Microbacia Tamandupá, servindo como testes (pilotos).

A aplicação do questionário consistiu nas seguintes etapas:

1. Apurou-se os nomes dos proprietários rurais da Microbacia através das coordenadas presentes no Levantamento de Unidades de Produção Agrícola - LUPA de 1995, realizado pela Casa da Agricultura do Município de Piracicaba. Estas coordenadas correspondiam a 24 quadrantes da Carta do IBGE de 1969 (Figura 5); 


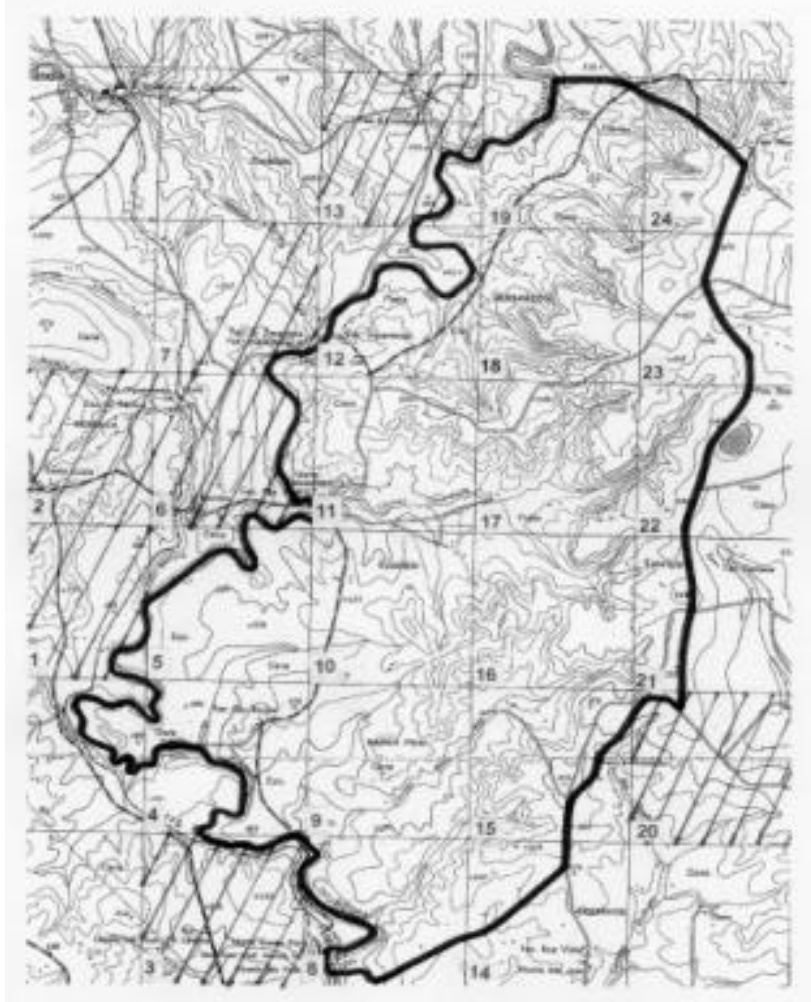

$\nabla / 7$ Quadrantes eliminados.

Figura 5 - Microbacia Tamandupá dividida em quadrantes.

2. Eliminou-se os 7 quadrantes cujas áreas pertencentes à Microbacia eram muito pequenas (Em destaque na Figura 5), atingindo o número de 61 proprietários assim distribuídos:

\begin{tabular}{|c|c|}
\hline Quadrante & № de proprietários \\
\hline 4 & 9 \\
\hline 5 & 2 \\
\hline 8 & 5 \\
\hline 9 & 5 \\
\hline 10 & 2 \\
\hline 11 & 1 \\
\hline 12 & 7 \\
\hline 14 & 16 \\
\hline 15 & 6 \\
\hline 19 & 6 \\
\hline 23 & 1 \\
\hline 24 & 1 \\
\hline
\end{tabular}

Quadro 3 - Distribuição dos proprietários rurais nos quadrantes. OBS.: Optou-se aqui, por não divulgar os nomes dos proprietários. 
3. Procurou-se os números de telefone destes proprietários na Casa da Agricultura e na Lista Telefônica.

4. Efetuou-se contato por telefone com alguns proprietários com o intuito de marcar dia, hora e local para aplicação do Questionário, porém, constatando-se o insucesso deste primeiro contato pois os proprietários mostraram-se desconfiados e não quiseram marcar a entrevista, optou-se por ir direto a campo;

5. Em campo, na área rural da Microbacia, foram entrevistados pessoalmente pela pesquisadora 16 proprietários no período de 4 meses. Este baixo número deveu-se à dificuldade de locomoção e de localização dos proprietários, visto que, muitos não residem na área da Microbacia (66 \%);

6. Optou-se também, por envolver 40 alunos de uma disciplina de graduação da ESALQ/USP na aplicação dos questionários junto aos 45 proprietários que ainda não haviam sido entrevistados. Eles estudaram previamente as perguntas e foram instruídos sobre a maneira de abordar os proprietários rurais. Obtiveram sucesso em aplicar o Questionário junto a 14 pessoas. Os outros 31 proprietários não foram encontrados ou se recusaram a responder às perguntas propostas;

7. Efetuou-se então a transcrição destas 30 entrevistas (Anexo C) e analisouse quantitativamente as respostas, agrupando-as em categorias e calculando suas porcentagens. Qualitativamente, foram destacadas algumas respostas mais indicativas da percepção dos proprietários rurais frente ao elemento arbóreo de suas propriedades e à legislação florestal vigente;

8. Realizou-se também a análise separada dos resultados dos questionários aplicados pela pesquisadora e pelos alunos da disciplina de graduação, buscando detectar se havia alguma diferença relevante entre os dois grupos de respostas;

9. Buscando estratificar os dados obtidos, ou seja, separá-los de acordo com as informações fornecidas pelos mesmos para que fossem efetuadas comparações categorizadas, foram atribuídos conceitos relativos ao grau de percepção que os proprietários rurais possuíam sobre árvore e sobre legislação florestal, que permitiram a construção da uma tabela de 
Estratificação dos Resultados (Item 4.2.2 dos Resultados). Os procedimentos para a atribuição destes valores, encontram-se descritos abaixo.

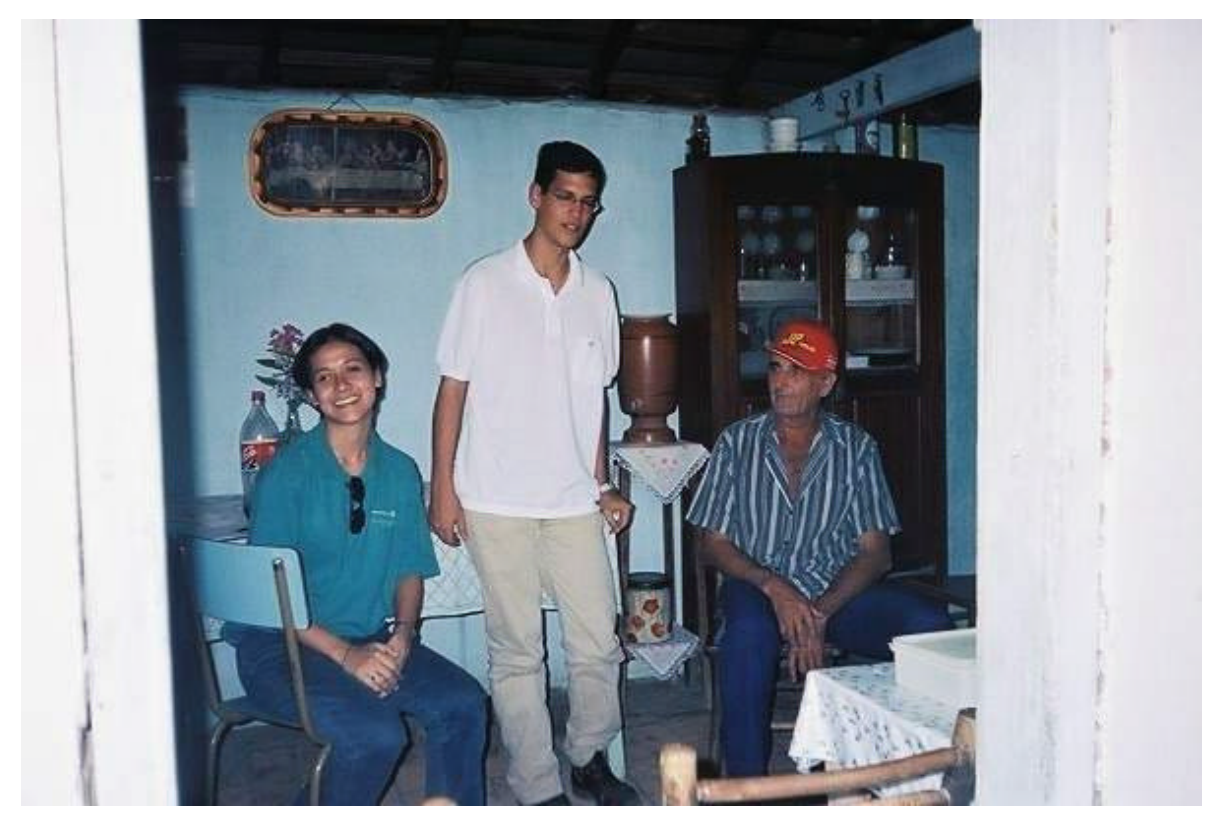

Figura 6 - Alunos e proprietário rural.

\subsubsection{Procedimentos para Estratificação dos Resultados}

Para atender ao primeiro objetivo específico apresentado na presente pesquisa, ou seja, realizar um estudo sobre a percepção que os proprietários rurais possuem do elemento arbóreo e da legislação florestal, utilizou-se como um dos instrumentos de trabalho, a estratificação dos resultados obtidos junto ao questionário aplicado.

Para isto, foram adotados os seguintes procedimentos:

1. Separação das questões relacionadas à árvore na propriedade rural, daquelas ligadas à percepção sobre a legislação florestal:

A) Questões relacionadas à árvore: 5, 7, 10, 11,12, 13, 15, 18, 19, 20, 21, 22, 32.

B) Questões relacionadas à legislação: 6, 24, 25, 26, 27, 28, 29, 30, 31. 
2. Atribuição de valores numéricos relativos a determinados graus de percepção*:

Percepção Ruim: 1

Percepção Regular: 2

Percepção Média: 3

Percepção Boa: 4

Percepção Ótima: 5

3. Análise das respostas dadas pelos indivíduos para as questões das duas categorias (relacionadas à percepção sobre árvores e relacionadas à percepção sobre legislação) e atribuição de um conceito para cada pessoa de acordo com a somatória das notas obtidas em cada questão.

4. Agrupamento das pessoas de acordo com o conceito obtido.

5. Realização de comparações entre os grupos de pessoas com determinado grau de percepção e as características de cada grupo de entrevistados: tamanho da propriedade, grau de escolaridade, idade e o fato de residir ou não na propriedade rural.

\section{* Detalhamento do item 2:}

\section{A) Atribuição de notas relacionadas à Percepção sobre Árvores:}

Questão 5: Para atribuir valores relacionados ao grau de percepção sobre a atual cobertura de árvores nas propriedades dos entrevistados, optou-se por conceder as seguintes notas:

1 - Para aqueles que não sabem (não observaram, não perceberam);

2 - Para aqueles que diminuíram a quantidade de árvore;

3 - Para aqueles que declararam ser igual a quantidade encontrada ao adquirir a propriedade;

4 - Para aqueles que promoveram um acréscimo de árvores; 
5 - Para aqueles que demonstraram motivação espontânea para promover aumento da quantidade de árvores em sua propriedade.

Questão 7: A percepção em relação a mudanças no ambiente, foi trabalhada da seguinte forma:

1 - Para aqueles que não perceberam mudanças ou não sabem dizer se perceberam ou não;

2 - Para aqueles que perceberam algo mas não comentaram o que;

3 - Para aqueles que perceberam mudanças não relacionadas a árvores;

4 - Para aqueles que perceberam mudanças positivas ou negativas relacionadas a árvores, mas cuja associação à ausência ou presença de elemento arbóreo, não foi declarada;

5 - Para aqueles que perceberam mudanças positivas e negativas relacionadas a árvores e declararam esta relação causa-efeito.

Questão 10: A respeito de já terem ou não plantado árvores na propriedade, atribuiuse:

1 - Para aqueles que não plantaram;

2 - Para aqueles que plantaram por obrigação;

3 - Para aqueles que plantaram por motivos utilitaristas;

4 - Para aqueles que plantaram por motivos diversos;

5 - Para aqueles que declaradamente plantaram para promover a recuperação ambiental.

Questão 11: Questionando a possibilidade de vir a plantar árvores na propriedade, e qual a motivação para isto, foram atribuídas notas semelhantes à questão 10 , acreditando que a motivação ambiental mostra uma percepção mais positiva do que a 
motivação utilitarista/financeira (que pode mudar a qualquer momento de acordo com o mercado).

Questão 12: A respeito dos motivos que levariam a não plantar árvores na propriedade, atribuiu-se:

1 - Para aqueles que apontaram a falta de fiscalização como motivo para não plantar; 2 - Para aqueles que declararam motivos operacionais (Mão de obra, tempo, etc.); 3 - Para quem levantou motivos financeiros;

4 - Para aqueles que alegaram existência de barreiras físicas (espaço, sombra, etc.); 5 - Para aqueles que declararam não haver motivo que impediriam o plantio de árvores em suas propriedades.

Obs.: Atribuiu-se maior nota para aqueles que alegaram motivos físicos porque acredita-se que muitas vezes, estes são mais difíceis de solucionar (falta de espaço, por exemplo), enquanto que, motivos operacionais poderiam ser resolvidos com a adesão a algum programa de auxílio ao florestamento. A falta de fiscalização demonstra total desmotivação para o plantio voluntário.

Questão 13: Questionados sobre a importância das árvores isoladas (espalhadas pela propriedade), atribuiu-se:

1 - Para aqueles que declaram não observar qualquer importância para árvores isoladas;

2 - Para aqueles que declararam haver pouca importância;

3 - Para aqueles que consideram a importância média, relacionada a alguma utilidade;

4 - Para aqueles que vêem muita importância;

5 - Para aqueles que vêem muita importância, descrevendo-a com sentimento. 
Questão 15: Sobre a existência de faixa de floresta ao longo dos rios, atribuiu-se as seguintes notas:

1 - Para inexistência de faixa de mata ciliar;

2 - Para existência menor que a exigida por lei;

3 - Para propriedades cuja área está em processo de regeneração natural;

4 - Para propriedades com faixa equivalente à exigida por lei;

5 - Para propriedades com faixa maior que a exigida por lei.

Questão 18: A respeito dos sonhos para a propriedade no futuro, atribui-se as seguintes notas de acordo com a pretensão:

1 - Para aqueles que não tem qualquer pretensão para o futuro;

2 - Para aqueles que desejam vender a propriedade ou ampliar área de plantio de cana;

3 - Para aqueles que desejam construir pesqueiro ou diversificar culturas;

4 - Para quem busca paz e tranqüilidade ou pretende desenvolver o ecoturismo e o lazer;

5 - Para quem visa promover a adequação ambiental.

Questão 19: Questionados sobre a serventia de árvores e florestas, atribuiu-se:

1 - Para aqueles que não vêem serventia ou não sabem dizer;

2 - Para aqueles que acreditam que as árvores só servem para adequar a propriedade às exigências legais;

3 - Para aqueles que acham que as árvores só servem para trazer benefícios pessoais;

4 - Para aqueles que acreditam que as árvores trazem benefícios ambientais;

5 - Para aqueles que relacionam as árvores a benefícios pessoais e ambientais. 
Questão 20: Questionados sobre a necessidade de proteção das florestas e matas, atribuiu-se:

1 - Para quem respondeu que não há necessidade;

2 - Para quem respondeu que sim, mas apenas se der lucro;

3 - Para quem respondeu que sim, mas desde que não o prejudique;

4 - Para quem respondeu que sim, pelo bem de todos;

5 - Para quem respondeu que sim, para a preservação ambiental.

Questão 21: Questionados sobre o tipo de árvore deve ser protegido e que tipo deve ser derrubado, atribuiu-se:

1 - Para aqueles que não sabem dizer;

2 - Para os que declaram que depende do fato de atrapalhar ou não o ser humano;

3 - Para aqueles que declaram de pode derrubar de acordo com a necessidade;

4 - Para aqueles que acham que as ameaçadas de extinção devem ser protegidas de qualquer maneira;

5 - Para aqueles que todas as árvores devem ser protegidas.

Questão 22: Opinando sobre a função da Mata Ciliar em os cursos d'água, atribui-se:

1 - Para aqueles que acreditam que a mata não protege os cursos d'água;

2 - Para quem acredita que protege, mas não na propriedade dele;

3 - Para quem acha que sim, mas em parte;

4 - Para quem acha que sim e justifica a forma de proteção;

5 - Para quem acha que sim e detalha a forma de proteção de maneira convicta.

Questão 32: Questionados sobre o conhecimento de reflorestamentos em outras propriedades e quais os seus efeitos, atribuiu-se: 
1 - Para quem não conhece nenhuma propriedade que tenha sido reflorestada;

2 - Para quem demonstra conhecimento do reflorestamento, mas não das conseqüências;

3 - Para quem demonstra conhecimento do reflorestamento, com impressões ruins;

4 - Para quem demonstra conhecimento do reflorestamento, com boas impressões;

5 - Para quem demonstra conhecimento do reflorestamento, com boas impressões e justificativas.

\section{B) Atribuição de notas relacionadas à Percepção sobre a Legislação Florestal:}

Questão 6: Questionados sobre a existência de reserva legal florestal averbada, atribuiu-se:

1 - Para os que não possuem;

5 - Para os que possuem.

Questão 15: Questionados sobre a existência de faixa de floresta ou mata ao longo dos cursos d'água, atribuiu-se:

1 - Para quem declarou que em sua propriedade não existe esta faixa;

2 - Para quem declarou que existe, mas é menor que a exigida por lei;

3 - Para quem declarou que a mata está em processo de regeneração natural;

4 - Para quem declarou que a faixa de mata é igual à exigida por lei;

5 - Para quem possui faixa maior que a exigida por lei.

Questão 24: Opinando a respeito da necessidade de punição das pessoas que cometem infrações contra o meio ambiente, atribuiu-se:

1 - Para quem não sabe dizer se deve haver punição;

2 - Para aqueles que declaram que não deve haver punição; 
3 - Para aqueles que acreditam que as pessoas não devem ser punidas se agirem em caso de necessidade;

4 - Para aqueles que acreditam que as pessoas não devem ser punidas se agirem em caso de acidente;

5 - Para aqueles que acreditam que as pessoas devem ser punidas.

Questão 25: Questionados sobre o conhecimento da existência de leis que protegem a Natureza, atribuiu-se:

1 - Para aqueles que não sabem da existência;

2 - Para aqueles que apenas sabem que existem leis mas não conhecem o conteúdo; 3 - Para aqueles que sabem que existem leis, mas apontam para a necessidade de maior orientação para a aplicação das mesmas;

4 - Para aqueles que sabem da existência das leis e acreditam que tem coisas boas ou ruins;

5 - Para aqueles que sabem da existência das leis e fazem comentários a respeito das mesmas.

Questão 26: Questionados sobre o conhecimento do Código Florestal, atribuiu-se:

1 - Para aqueles que declararam não conhecê-lo;

2 - Para aqueles que apenas sabem que o Código Florestal existe;

3 - Para aqueles que conhecem o Código, mas não entendem muito bem seu conteúdo;

4 - Para aqueles que conhecem o Código e o acham adequado ou inadequado;

5 - Para aqueles que conhecem o Código, declaram se o acham adequado ou não, e fazem comentários a respeito.

Questão 27: Questionados sobre o que deve ser feito para que as leis florestais sejam cumpridas, atribuiu-se: 
1 - Para aqueles que não sabem dizer;

2 - Para quem acredita que nada deve ser feito pois as leis já são cumpridas;

3 - Para quem acredita que deve ser dado incentivo em dinheiro para que haja o respeito às leis;

4 - Para quem declara que deve-se adequar/melhorar as penas ou a fiscalização;

5 - Para quem declara que deve-se melhorar as leis ou a divulgação.

Questão 28: Opinando sobre a obrigação de proteger a Natureza, atribuiu-se:

1 - Para quem acha que ninguém tem esta obrigação;

2 - Para quem acredita que é dos aplicadores da Lei;

3 - Para quem acredita que é do governo ou dos proprietários rurais;

4 - Para quem diz que é do governo e dos proprietários;

5 - Para quem acha que é de todos.

Questão 29: Questionados sobre a questão de propriedade e responsabilidade sobre a água, atribui-se:

1 - Para quem não sabe dizer de quem é a água ou a responsabilidade sobre ela;

2 - Para quem acha que a água pertence e é responsabilidade da cidade;

3 - Para quem acha que a água pertence e é responsabilidade do proprietário ou do governo;

4 - Para quem acha que a água pertence e é responsabilidade do governo $\underline{e}$ dos proprietários;

5 - Para quem acha que a água pertence e é responsabilidade de todos.

Questão 31: Questionados sobre a maneira que os proprietários percebem os programas de florestamento da região, atribuiu-se: 
1 - Para quem não conhece nenhum programa;

2 - Para quem apenas ouviu falar de algum programa;

3 - Para quem conhece, e não gostaria de participar;

4 - Para quem conhece, e gostaria de participar;

5 - Para quem já está participando.

Atribuídas as notas para as respostas dadas às questões acima, foi possível ainda acrescentar uma pontuação relacionada a observações diretas feitas em campo pela pesquisadora, para os primeiros 16 entrevistados. Deste modo, pode-se dizer que os dados provenientes destas entrevistas, receberam melhor tratamento e puderam ser analisados em maior profundidade no que diz respeito à identificação da percepção.

Obs.: Embora este procedimento de atribuição de notas fundamente-se em opções possíveis de questionamentos, o mesmo foi adotado com o intuito de melhor visualizar as tendências perceptivas do público alvo, para que fossem realizadas análises que possibilitassem diagnosticar algum padrão entre as respostas e as características dos diversos grupos de entrevistados.

\subsection{Outras fontes de informação}

\subsubsection{Profissionais da área}

Buscando valer-se da experiência de pessoas que já atuam na área, foram feitas entrevistas junto a diversos profissionais, solicitando sugestões e respostas para os seguintes questionamentos:

1. Como você vê a possibilidade de adesão do proprietário rural para o plantio de árvores em sua propriedade (possível, fácil, difícil, ...)? 
2. Qual seria a porta de entrada para o diálogo e adesão dos proprietários? Quem (homem, mulher, criança)? Como (curso, palestra, visita, fiscalização,...)?

3. Como despertar o interesse dos proprietários rurais? Quais os pontos motivadores (dinheiro, lei, amor, conhecimento, ...?

4. Na sua opinião, a lei estimula ou não o plantio de árvores? Você tem alguma sugestão para melhorar a sua redação, conteúdo e/ou eficácia?

Os entrevistados foram:

O Secretário da Agricultura do Município de Piracicaba; uma engenheira agrônoma da Casa da Agricultura do Município; uma educadora ambiental que trabalha em escolas rurais; uma técnica do Consórcio Intermunicipal de Bacias Hidrográficas; o presidente do Sindicato Rural e da Cooperativa dos Plantadores de Cana; uma consultora do Instituto de Pesquisas e Estudos Florestais - IPEF; um professor da ESALQ/USP e um engenheiro do DEPRN.

\subsubsection{Atividades Complementares}

Diversas atividades complementares foram desenvolvidas acreditando-se que o enfrentamento de questões como a árvore na propriedade rural e a relação do proprietário rural com o meio ambiente e com a legislação florestal, é bastante complexo. Assim, procurou-se participar de eventos, encontros, congressos, projetos, trabalhos de campo e atividades didáticas, para uma maior compreensão da realidade do setor rural e ambiental e para adquirir maior propriedade no trato das atividades propostas pela presente pesquisa.

Essas atividades encontram-se descritas no Anexo F. 


\subsection{Desenvolvimento do processo de intervenção educacional}

"O resgate/manutenção da qualidade ambiental no meio rural deve incluir o resgate/manutenção das responsabilidades mútuas entre proprietários e instituições que atuam no meio ambiente rural, e a intervenção educativa apresenta lugar na atual problemática através de seus componentes estruturais como a comunicação, participação, construção de conhecimento e capacitação para a ação" (Malagodi, 2000, p.104).

O presente trabalho apresentou como um de seus objetivos principais, a elaboração de uma proposta de intervenção educacional. Este produto da pesquisa, teve desde o início dos trabalhos, a intenção de levar em consideração as informações obtidas em campo, nas entrevistas, nos levantamentos secundários e nos trabalhos de autores que já desenvolveram pesquisas correlatas.

Dentre as considerações julgadas importantes nesta pesquisa, destacam-se a imprescindibilidade do planejamento participativo, levantada por Martins (2000, p.92 a 95); a necessidade do planejamento contemplar as dimensões de continuidade, coordenação, integração, participação e flexibilidade, abordadas por Costa (1986, p.1); a importância de estabelecer o diálogo entre as partes, ressaltada por Tassara \& Damergian (1996, p.307) ${ }^{12}$; o conhecimento da realidade concreta, descrita por Freire $\left(1990\right.$, p.34) ${ }^{13}$; dentre outras.

Ainda para auxiliar na elaboração de uma intervenção educacional, os questionários junto aos 30 proprietários rurais pertencentes à Microbacia Tamandupá

\footnotetext{
12 "É preciso pensar as conseqüências da ausência de diálogo, da uniformização do discurso e sua propagação através da mídia na tentativa de padronizar, sabotando os limites definidores das identidades. Assim como a troca de experiências é fundamental para a construção da subjetividade, a aceitação do outro como singular, como ser desejante, inscrito em um sistema simbólico, portador de uma identidade psíquica e de uma identidade cultural, é crucial para a sobrevivência do humano".

13“"A realidade concreta de uma certa área, não se reduz a um conjunto de fatos e dados materiais. Inclui também a percepção que deles esteja tendo a população neles envolvida". Assim, a realidade concreta se dá na relação dialética entre objetividade e subjetividade. "Simplesmente, não posso conhecer a realidade de que participam a não ser com eles como sujeitos também deste conhecimento. Fazendo pesquisa, educo e estou me educando com os grupos populares" (Freire, 1990, p.34 a 36). Freire (1990 - pág. 37), cita ainda, declarações do Presidente Nyerere da Tanzânia: "Assim como não posso desenvolver um homem, uma mulher, uma pessoa, se ele ou ela não se desenvolverem, tampouco posso desenvolver uma nação sem a sua gente". Para Nyerere, não há desenvolvimento sem a presença curiosa e responsável das massas populares na reconstrução da sua sociedade. "Daí que o seu projeto educativo se oriente sempre neste sentido", aconselha Freire.
} 
continham uma questão em que era solicitada a sugestão de assuntos a serem discutidos durante um curso a ser oferecido aos proprietários rurais e a maneira mais adequada para a realização do mesmo. Os entrevistados opinaram sobre o conteúdo deste curso, os horários e locais mais apropriados e a melhor época para sua realização.

Seguindo estas orientações, planejou-se a realização de um conjunto de palestras sobre árvores em propriedades rurais abordando questões como legislação florestal, programas de auxílio ao reflorestamento, alternativas econômicas envolvendo árvores e participação popular na tomada de decisões que viabilizem o seu plantio em propriedades rurais. O horário apontado como mais apropriado foi o período noturno, à partir das 19 horas. A época do ano sugerida foi o período da entressafra da cana-deaçúcar, de novembro a janeiro, pois este é o principal produto cultivado na região. $O$ local indicado pela proximidade das propriedades e conhecimento de todos, foi a Usina Costa Pinto.

Somando-se a estas indicações e para que houvesse uma maior participação do público alvo na preparação desta intervenção, foi realizada uma Palestra de Planejamento e Divulgação no mês de outubro, quando discutiu-se como seria este conjunto do palestras, confirmou-se os assuntos de maior interesse dos proprietários, colheu-se inscrições e marcou-se as primeiras datas para a realização de palestras.

A idéia de efetuar todos os encontros em uma única semana, realizando palestras todos os dias, foi apontada como inviável pelos proprietários. Os mesmos sugeriram um intervalo maior de tempo entre uma palestra e outra, para não ficar cansativo e não sobrecarregar os participantes.

Estas palestras tiveram o intuito de subsidiar a elaboração da proposta de Intervenção Educacional. 


\subsubsection{Palestra de Planejamento e Divulgação}

Para a realização da primeira palestra, foram considerados o horário e local sugeridos pelos proprietários rurais da Microbacia Tamandupá: às 19:30h, na Usina Costa Pinto.

Foram distribuídos 16 convites pessoalmente e 14 pelo correio, a todos os proprietários entrevistados. Para aqueles convidados via correspondência, foram efetuados telefonemas para confirmação do endereço e adiantamento do convite. Foi solicitado ainda, que estes proprietários convidassem vizinhos e conhecidos e que alguns fixassem cartazes nos locais considerados de maior circulação na região.

Planejou-se a abordagem de diversos assuntos como: o histórico de degradação ambiental no país e no mundo, os motivos pelos quais se deve proteger as florestas, quais os dispositivos legais para isto, quais os direitos e obrigações dos proprietários rurais, quais as características da região em que suas propriedades estão inseridas e como estas características interferem na conservação dos recursos naturais, qual a importância de atitudes individuais e coletivas, etc.

\subsubsection{Elaboração de um Cronograma de Palestras}

A partir dos resultados dos questionários aplicados, das observações de campo e da palestra de planejamento e divulgação, foi elaborado um cronograma de atividades objetivando subsidiar a elaboração de uma propostas de intervenção educacional. Propunha-se não apenas a promover palestras, mas também a divulgar eventos que estavam por ocorrer no Município e a buscar maneiras de envolver familiares e pessoas do convívio dos proprietários rurais, como mulheres, crianças e caseiros. 


\subsection{Análise dos resultados}

Conforme descrito anteriormente, optou-se pela realização de análise qualitativa e quantitativa das respostas obtidas nas entrevistas, bem como, considerouse aspectos observados e anotados pela pesquisadora em seu diário de campo. Para a triangulação das informações, utilizou-se também as respostas das entrevistas feitas pelos alunos da ESALQ/USP, os dados secundários sistematizados por outros pesquisadores que atuam na área, as reações dos proprietários rurais nos contatos telefônicos e pessoais, o comparecimento e comportamento nas palestras e as reflexões dos técnicos entrevistados que atuam no setor rural.

Deste modo, o contato com proprietários rurais através de visitas de campo ${ }^{14}$, a familiarização com as questões relacionadas à extensão rural e a participação em eventos como encontros na Casa da Agricultura, na Prefeitura, em reuniões realizadas pelas usinas canavieiras da região, palestras promovidas por diversas instituições e destinadas aos proprietários rurais, etc, apresentaram destacada importância.

A sistematização destes dados, permitiu a utilização de um método de leitura e análise baseado na multireferencialidade. Segundo Ardoino (1990, p.119), "a multireferencialidade é esta pluralidade de olhares e de esclarecimentos que supõe, por sua vez, diferentes linguagens descritivas e interpretativas que não devem ser confundidas ou reduzidas umas às outras porque derivam, de fato, normalmente, de paradigmas bem distintos".

Para Minayo (1996), existem três finalidades para a etapa de análise: estabelecer uma compreensão dos dados coletados, confirmar ou não os pressupostos da pesquisa e/ou responder às questões formuladas, e ampliar o conhecimento sobre o assunto pesquisado, articulando-o ao contexto cultural da qual faz parte.

\footnotetext{
14 "Edgar Morin e Albert Meister - e muitos outros sociólogos de campo - notaram que a informação era maximizada quando eram convidados pelos observados a beber uma xícara de café ou um copo de vinho" (Laurau, 1998).
} 


\section{RESULTADOS E DISCUSSÃO}

\subsection{Público Alvo e área de estudo}

Definidos o público alvo (proprietários rurais) e área de estudo (Microbacia Tamandupá, pertencente à Bacia do Rio Corumbataí), procurou-se detectar quais eram, quantas existiam e onde se localizavam as propriedades da região de interesse. Constatou-se então, a dificuldade em adquirir estes dados, pois eles não se encontravam disponíveis em nenhum dos órgãos consultados: Secretaria do Meio Ambiente, Secretaria de Agricultura e Abastecimento, Casa da Agricultura, DEPRN e IBGE. Havia sim, a lista de proprietários rurais do município como um todo (em ordem alfabética), mas não existia separação por bairros, muito menos, por microbacias. A opção encontrada foi a de consultar todas as fichas de proprietários cadastrados pela Casa da Agricultura de Piracicaba (2345 proprietários, até o ano de 1995) e verificar as coordenadas geográficas dos mesmos (latitude e longitude), separando aquelas que coincidiam com as coordenadas da Microbacia em questão. $O$ problema encontrado neste procedimento, foi que a localização das propriedades existentes nas fichas, não eram exatas, e sim, por quadrantes de $4 \mathrm{~km}^{2}$ cada. Além disto, os dados eram de 1995, e segundo a engenheira agrônoma responsável pela Casa da Agricultura, estavam bastante desatualizados. De qualquer forma, foi possível chegar ao número de 61 proprietários espalhados por 24 quadrantes.

Numa primeira etapa de trabalho, foram entrevistados 16 proprietários, priorizando-se aqueles que estivessem mais próximos ao Rio Corumbataí. Num segundo momento, com o envolvimento de estudantes de graduação (já citado no item 5.2.2. da Metodologia), foi tentado o contato com os outros 45 proprietários da 
Microbacia, porém foi obtido sucesso de localização e realização de entrevista, com apenas 14 deles. Somou-se assim, 30 entrevistas realizadas, correspondendo a aproximadamente $50 \%$ dos proprietários que se acreditava pertencer a Microbacia Tamandupá. Vale acrescentar que alguns dos nomes encontrados no levantamento feito na Casa da Agricultura, na realidade não eram mais de proprietários da região. Houve por exemplo, a verificação de que algumas propriedades foram vendidas recentemente para um único dono, proprietário de um Porto de Areia da região, podendo justificar uma diminuição do número de proprietários encontrados.

Com relação à Microbacia Tamandupá, foram levantados diversos dados secundários com o intuito de contextualizar as informações a serem transmitidas aos proprietários da região, destacando-se: a Microbacia Tamandupá possui 4.675,67 hectares, com três cursos d'água principais, contribuintes do Rio Corumbataí; suas nascentes estão distribuídas numa região com 1075,00 ha $(22,99 \%)$ de cobertura florestal pouco alterada; 44,86 ha $(0,96 \%)$ com cobertura florestal alterada; 99,82 ha $(2,14 \%)$ de várzeas; 92,84 ha $(1,98 \%)$ com cobertura florestal exótica; 802,22 ha $(17,16 \%)$ de pastagens e 2400,76 ha $(51,35 \%)$, a maior parte da área, revestidos por plantações de cana-de-açúcar. Estes dados foram obtidos através da análise do Mapa de Uso do Solo do Projeto Piloto Tamandupá, apresentado no Relatório Bimestral Abril / Maio de 2000 (IPEF / SEMAE, 2000). Existem outros mapas com distribuição hídrica, tipo de solo, cobertura vegetal, declividade, etc, disponíveis para fins didáticos.

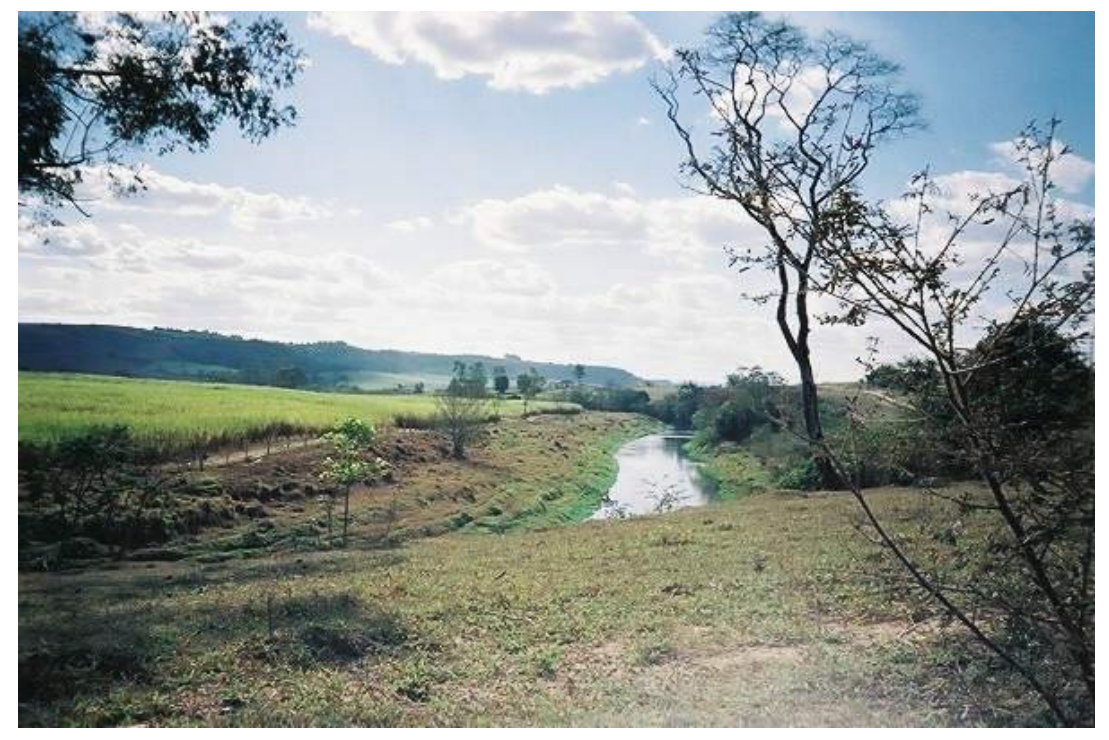

Figura 7 - Margem do rio Corumbataí sem cobertura florestal. 


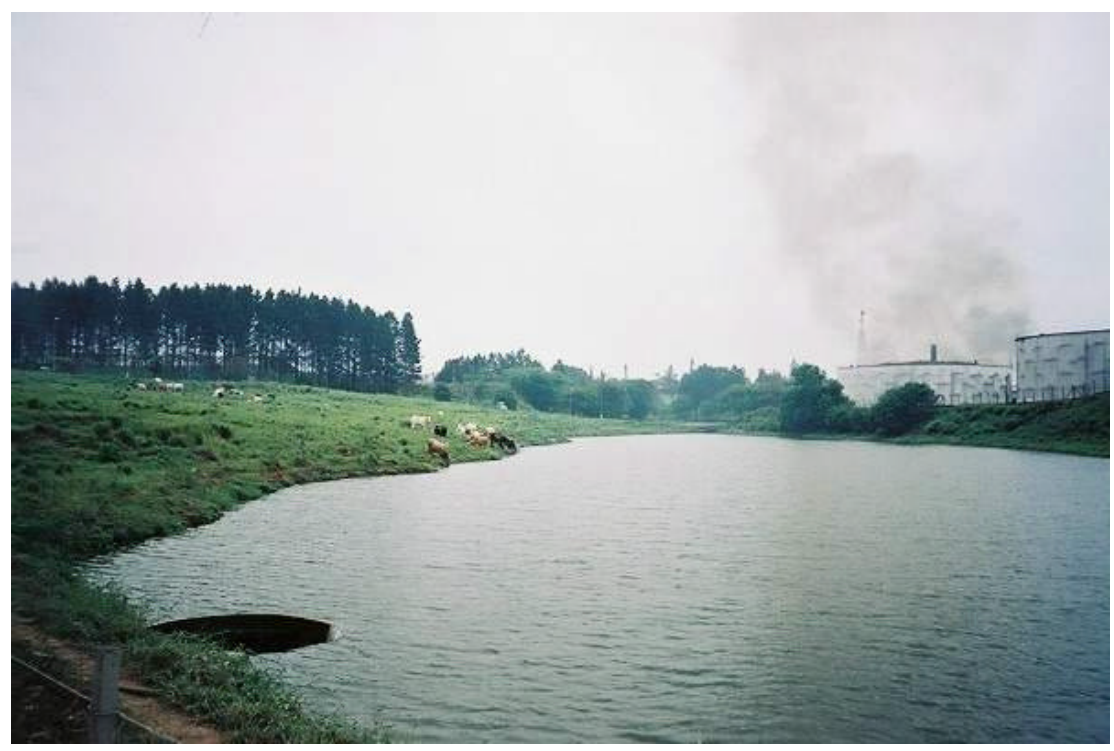

Figura 8 - Área desmatada e com gado nas margens.

\subsection{Diagnóstico de Percepção}

Foram formuladas 35 questões para cada um dos proprietários entrevistados, sendo 18 mais voltadas à caracterização do proprietário e respectiva área, e 17 sobre opiniões dos mesmos a respeito da proteção da natureza, legislação florestal, dentre outros assuntos.

$\mathrm{Na}$ tentativa de melhor visualizar os resultados das entrevistas, optou-se por separar as respostas obtidas, em categorias que permitissem o agrupamento de opiniões semelhantes e o cálculo das respectivas porcentagens. O Quadro a seguir, apresenta os resultados obtidos neste processo. 


\begin{tabular}{|c|c|}
\hline Questões & Total de Respostas (\%) \\
\hline \multicolumn{2}{|c|}{ Q.1. Há quanto tempo a propriedade pertence a este dono? } \\
\hline$<20$ anos & 30 \\
\hline $21-40$ anos & 23,3 \\
\hline $41-60$ anos & 23,3 \\
\hline$>61$ anos & 23,3 \\
\hline \multicolumn{2}{|l|}{ Q.2. Reside na área? } \\
\hline Sim & 36,7 \\
\hline Não & 63,3 \\
\hline \multicolumn{2}{|l|}{ Q.2. Possui outra propriedade? } \\
\hline Sim & 43,3 \\
\hline Não & 56,7 \\
\hline \multicolumn{2}{|c|}{ Q.3. Alguma ativi dade econômica é desenvolvida na propriedade? Qual? } \\
\hline Apenas cana & 30 \\
\hline Cana e subsistência & 16,7 \\
\hline Cana e outra ativ. Econômica & 16,7 \\
\hline Pasto & 23,3 \\
\hline Porto de areia e pasto & 6,7 \\
\hline Sem atividade econômica & 6,7 \\
\hline \multicolumn{2}{|c|}{ Q.4. Quando o senhor adquiriu (comprou) a propriedade, existia mata? } \\
\hline Sim & 20 \\
\hline Pouca coisa & 40 \\
\hline Não & 36,7 \\
\hline Não sei dizer & 3,3 \\
\hline \multicolumn{2}{|c|}{$\begin{array}{l}\text { Q.5. Como a propriedade é hoje em relação à cobertura de árvores (quanto e } \\
\text { onde)? }\end{array}$} \\
\hline Aumentou/Aumentando & 53,3 \\
\hline Igual & 33,3 \\
\hline Diminuiu & 6,7 \\
\hline Não sei dizer & 6,7 \\
\hline \multicolumn{2}{|c|}{$\begin{array}{l}\text { Q.6. Existe alguma mata em sua propriedade, que tenha sido averbada como } \\
\text { Reserva Legal? }\end{array}$} \\
\hline Sim & 10 \\
\hline Não & 90 \\
\hline \multicolumn{2}{|c|}{$\begin{array}{l}\text { Q.7. Você tem percebido alguma mudança no ambiente? A que você atribui } \\
\text { esta mudança? }\end{array}$} \\
\hline Sim, neg. (+calor, -chuva, solo fraco) & 60 \\
\hline Sim, positiva (mais peixes) & 3,3 \\
\hline Sim, positivas e negativas & 10 \\
\hline Não & 20 \\
\hline Não sei dizer & 6,7 \\
\hline
\end{tabular}


Questões

|Total de Respostas (\%)

Q.8. Usa água de poço? Por que?

Sim, para beber

53,3

Não

40

Não sei dizer

6,7

Q.9. Tem nascentes na propriedade? Você utiliza esta água?

\begin{tabular}{|l|l}
\hline Sim, para beber & 23,3 \\
\hline
\end{tabular}

\begin{tabular}{|l|l}
\hline Sim, para criação & 20 \\
\hline Sim, sem uso
\end{tabular}

\begin{tabular}{l|l} 
Sim, sem uso & 10
\end{tabular}

\begin{tabular}{|l|l|}
\hline Não & 43,3 \\
\hline Nă
\end{tabular}

\begin{tabular}{|l|l|}
\hline Não sei dizer & 3,3 \\
\hline
\end{tabular}

Q.10. Você já plantou árvores em sua propriedade? Com que finalidade?

\begin{tabular}{l|l} 
Sim, frutíferas & 23,3 \\
\hline
\end{tabular}

\begin{tabular}{|l|l}
\hline Sim, para embelezar & 3,3 \\
\hline Sim,
\end{tabular}

\begin{tabular}{l|l}
\hline Sim, para ter madeira & 6,7
\end{tabular}

\begin{tabular}{|l|l|}
\hline Sim, para recuperação ambiental & 36,7 \\
\hline
\end{tabular}

\begin{tabular}{|l|l|}
\hline Não & 30 \\
\hline
\end{tabular}

Q.11. Plantaria (outras, caso já tenha plantado)? Por quê, para quê e de que tipo?

\begin{tabular}{l|l} 
Sim, frutífera & 10 \\
\hline Sim, para emberar & 3,3
\end{tabular}

\begin{tabular}{l|l}
\hline Sim, para embelezar & 3,3 \\
\hline Sim,
\end{tabular}

\begin{tabular}{l|l}
\hline Sim, para ter madeira & 10
\end{tabular}

\begin{tabular}{|l|l|}
\hline Sim, para recuperação ambiental & 26,7 \\
\hline
\end{tabular}

\begin{tabular}{|l|l}
\hline Sim, para turismo & 3,3 \\
\hline
\end{tabular}

\begin{tabular}{|l|l|}
\hline Sim, sem explicação & 20 \\
\hline
\end{tabular}

\begin{tabular}{|l|l|}
\hline Não & 20 \\
\hline Nă & 6,7
\end{tabular}

\begin{tabular}{|l|l|}
\hline Não sei & 6,7 \\
\hline
\end{tabular}

Q.12. O que o levaria a não plantar árvores nativas na propriedade?

\begin{tabular}{|l|l|}
\hline Nada & 23,3 \\
\hline Tempo & 3,3 \\
\hline Espaço & 13,3 \\
\hline Mão de obra & 20 \\
\hline Dinheiro & 16,7 \\
\hline Sombra na lavoura & 3,3 \\
\hline Falta de Mudas adequadas ao solo & 16,7 \\
\hline Descaso da Polícia & 3,3 \\
\hline & \\
\hline Q. 13. Qual a importância que as árvores isoladas têm para o senhor? \\
\hline Madeira & 2,5 \\
\hline Rebate o Vento & 5 \\
\hline Animais & 10 \\
\hline Cheiro & 2,5 \\
\hline Sombra & 22,5 \\
\hline (continua) & \\
\hline
\end{tabular}




\begin{tabular}{|c|c|}
\hline Questões & Total de Respostas (\%) \\
\hline \multicolumn{2}{|l|}{ Q.13. (continuação) } \\
\hline $\mathrm{Ar}$ & 5 \\
\hline Refresca & 2,5 \\
\hline Fruta & 15 \\
\hline Beleza & 17,5 \\
\hline Preserva Espécies & 2,5 \\
\hline Importante em geral & 7,5 \\
\hline Sem importância & 7,5 \\
\hline \multicolumn{2}{|c|}{ Q.14. Sua propriedade apresenta problema de erosão? Como é esta área? } \\
\hline Sim & 26,7 \\
\hline Não & 73,3 \\
\hline \multicolumn{2}{|c|}{ Q.15. Sua propriedade possui faixas de floresta ao longo dos rios? } \\
\hline Menor que a legal & 23,3 \\
\hline Igual à legal & 30 \\
\hline Maior que a legal & 3,3 \\
\hline Em processo de regeneração natural & 16,7 \\
\hline Não possui & 16,7 \\
\hline Não sei/ Não há rio & 10 \\
\hline \multicolumn{2}{|c|}{$\begin{array}{l}\text { Q.16. Você se sente prejudicado por algum dano ao meio ambiente praticado } \\
\text { por vizinhos? }\end{array}$} \\
\hline Sim, Agrotóxico & 16,7 \\
\hline Sim, Cavalo Solto & 3,3 \\
\hline Sim, Desmatamento & 10 \\
\hline Sim, Restilo da usina & 3,3 \\
\hline Não & 66,7 \\
\hline \multicolumn{2}{|c|}{$\begin{array}{l}\text { Q.17. É bom estar numa bacia de abastecimento de água para Piracicaba? Por } \\
\text { que? }\end{array}$} \\
\hline Bom (água mais limpa, valor) & 53,3 \\
\hline Indiferente & 20 \\
\hline Ruim (+ pressão legal, - água) & 16,7 \\
\hline Não sei & 10 \\
\hline \multicolumn{2}{|c|}{ Q.18. O que você sonha para a sua propriedade no futuro (2, 10 e 30 anos)? } \\
\hline Diversificar culturas & 13,3 \\
\hline Pesqueiro & 10 \\
\hline Ecoturismo e lazer & 10 \\
\hline Melhorar, construir, arrumar & 10 \\
\hline Paz e tranqüilidade & 6,7 \\
\hline Vender & 10 \\
\hline Ampliar área de plantio & 3,3 \\
\hline Não tenho sonho para o futuro & 33,3 \\
\hline Não sei & 3,3 \\
\hline
\end{tabular}


Questões

|Total de Respostas (\%)

Q.19. Na sua opinião, para que servem as florestas e as matas?

\begin{tabular}{|l|l|}
\hline Frutos/Alimentos & 3,8 \\
\hline Beleza & 3,8 \\
\hline Madeira & 3,8 \\
\hline Clima & 1,9 \\
\hline Evitar erosão & 18,9 \\
\hline Sombra & 1,9 \\
\hline Biodiversidade & 18,9 \\
\hline Ar & 5,7 \\
\hline Água & 15,1 \\
\hline Meio Ambiente & 13,2 \\
\hline Controle de pragas & 1,9 \\
\hline Lei & 1,9 \\
\hline Serve para tudo & 3,8 \\
\hline Não sei & 1,9
\end{tabular}

Q.20. Elas (florestas e matas) devem ser protegidas? Por que?

\begin{tabular}{|l|l|}
\hline Sim & 16,7 \\
\hline Sim, para o bem de todos & 30 \\
\hline Sim, desde que não me prejudique & 3,3 \\
\hline Sim, para a preservação ambiental & 43,3 \\
\hline Sim, para obter lucros/recursos & 6,7 \\
\hline Não & 0
\end{tabular}

Q.21. Que tipo de árvore deve ser protegido?

\begin{tabular}{|c|c|}
\hline Nativas & 20 \\
\hline Protetivas/APP & 13,3 \\
\hline Ameaçadas de extinção ou de Lei & 3,3 \\
\hline Todas & 30 \\
\hline Frutíferas & 6,7 \\
\hline Que não atrapalha & 6,7 \\
\hline Não sei & 20 \\
\hline \multicolumn{2}{|c|}{ Q.21. Que tipo de árvore pode ser derrubado? } \\
\hline O que for necessário & 16,7 \\
\hline Pequeno porte ou sem Qualidade & 10 \\
\hline Nenhuma & 16,7 \\
\hline Eucalipto & 30 \\
\hline Que atrapalha (cana ou pasto) & 13,3 \\
\hline Mortas & 3,3 \\
\hline Não sei & 10 \\
\hline \multicolumn{2}{|c|}{$\begin{array}{l}\text { Q.22. Você acha que a mata ciliar realmente protege os cursos d'água? } \\
\text { Como? }\end{array}$} \\
\hline Sim & 80 \\
\hline (continua) & \\
\hline
\end{tabular}




\begin{tabular}{|c|c|}
\hline Questões & |Total de Respostas (\%) \\
\hline \multicolumn{2}{|l|}{ Q.22. (continuação) } \\
\hline Sim, mas não na minha propriedade & 6,7 \\
\hline Sim, mas deveria ser menor & 3,3 \\
\hline \begin{tabular}{|l|} 
Não \\
\end{tabular} & 3,3 \\
\hline Não sei & 6,7 \\
\hline \multicolumn{2}{|c|}{ Q.23. Você acredita que a fauna silvestre deve ser protegida? Por que? } \\
\hline Sim & 76,7 \\
\hline Sim, desde que não me prejudique & 20 \\
\hline Sim, liberando caça às vezes & 3,3 \\
\hline Não & 0 \\
\hline \multicolumn{2}{|c|}{$\begin{array}{l}\text { Q.24. O que você acha de quem põe fogo proposital ou derruba árvores } \\
\text { protegidas? Punir? }\end{array}$} \\
\hline Sim, devem ser punidas & 70 \\
\hline Não, devem ser conscientizadas & 10 \\
\hline Não, se foi por necessidade & 3,3 \\
\hline Não, em caso de acidente & 13,3 \\
\hline Não sei & 3,3 \\
\hline \multicolumn{2}{|c|}{$\begin{array}{l}\text { Q.25. Você sabe que existem leis que cuidam das matas? O que você pensa } \\
\text { sobre estas leis? }\end{array}$} \\
\hline Sim, mas não conheço o conteúdo & 30 \\
\hline Sim, acho que são boas & 6,7 \\
\hline Sim, acho que são ruins & 23,3 \\
\hline Sim, tem coisas boas e ruins & 6,7 \\
\hline Sim, mas não são obedecidas & 16,7 \\
\hline Sim, mas tem que orientar e fiscalizar & 13,3 \\
\hline Não & 3,3 \\
\hline \multicolumn{2}{|c|}{ Q.26. Você conhece o Código Florestal Brasileiro? Você o acha adequado? } \\
\hline Sim & 10 \\
\hline Sim, acho adequado & 0 \\
\hline Sim, acho exagerado / inflexível & 16,7 \\
\hline Sim, mas preciso entender melhor & 6,7 \\
\hline Sei que existe & 23,3 \\
\hline Não & 43,3 \\
\hline \multicolumn{2}{|c|}{$\begin{array}{l}\text { Q.27. O que você acha que deve ser feito para que as leis florestais sejam } \\
\text { cumpridas? }\end{array}$} \\
\hline Aumentar fiscalização & 16,3 \\
\hline Prepara melhor a polícia flor. & 16,3 \\
\hline Melhorar as leis & 4,7 \\
\hline Dar incentivo em dinheiro & 2,3 \\
\hline Aumentar as penas/ rapidez na apl. & 7 \\
\hline Diminuir as penas (abrandar) & 2,3 \\
\hline (continua) & \\
\hline
\end{tabular}




\begin{tabular}{|c|c|}
\hline Questões & Total de Respostas (\%) \\
\hline \multicolumn{2}{|l|}{ Q.27. (continuação) } \\
\hline Deixar o proprietário agir & 2,3 \\
\hline Fazer valer para todos & 14 \\
\hline Divulgar, orientar, informar, dar ex. & 25,6 \\
\hline Já são cumpridas & 2,3 \\
\hline Não sei & 77 \\
\hline \multicolumn{2}{|c|}{ Q.28. De quem você acha que é a obrigação de proteger a Natureza? } \\
\hline De todos & 76,7 \\
\hline Dos proprietários & 6,7 \\
\hline Dos proprietários, com ajuda do Gov. & 6,7 \\
\hline Do governo & 6,7 \\
\hline Dos aplicadores da Lei & 3,3 \\
\hline \multicolumn{2}{|c|}{ Q.29. De quem deveria ser a água presente na propriedade? } \\
\hline Todos & 40 \\
\hline Proprietário & 46,7 \\
\hline Governo & 3,3 \\
\hline Cidade & 6,7 \\
\hline Não sei & 3,3 \\
\hline \multicolumn{2}{|l|}{ Q.29. Quem deveria cuidar desta áqua? } \\
\hline Todos & 23,3 \\
\hline Proprietário & 56,7 \\
\hline Governo & 10 \\
\hline Cidade & 6,7 \\
\hline Não sei & 3,3 \\
\hline \multicolumn{2}{|c|}{$\begin{array}{l}\text { Q.30. E a faixa na beira dos cursos d'água? Quem deveria conservar / } \\
\text { recuperar? }\end{array}$} \\
\hline Proprietário & 26,7 \\
\hline Governo & 13,3 \\
\hline Proprietário, com ajuda do governo & 43,3 \\
\hline Todos & 16,7 \\
\hline \multicolumn{2}{|c|}{$\begin{array}{l}\text { Q.31. Você já ouviu falar de programas de auxílio ao florestamento? Qual? O } \\
\text { que achou? }\end{array}$} \\
\hline Sim & 10 \\
\hline Sim, e estou participando & 20 \\
\hline Sim, e gostaria de participar & 3,3 \\
\hline Sim, mas não gostaria de participar & 13,3 \\
\hline Apenas ouvi falar & 20 \\
\hline Não & 10 \\
\hline Não, mas gostaria de participar & 10 \\
\hline Não, talvez participe & 3,3 \\
\hline Não, e não gostaria de participar & 10 \\
\hline
\end{tabular}


Questões

Total de Respostas (\%)

Q.32. Você conhece alguma propriedade que tenha sido reflorestada? Qual o efeito disto?

Sim

Sim, foi ou está sendo bom

20

Sim, foi ou está sendo ruim

33,3

Sim, mas não sei o resultado

13,3

Não

13,3

20

Q.33. Gostaria de participar de um curso enfocando preservação da natureza e legislação?

Sim

63,3

Talvez

10

Não, porque não tenho interesse

13,3

Não, porque não tenho estudo

3,3

Não, porque sou velho, sem saúde

3,3

Não preciso, é bom para os outros

3,3

Não, porque não sou de Piracicaba

3,3

Q.33. Qual seria o melhor local?

\begin{tabular}{l|l}
\hline Qualquer lugar & 6,7
\end{tabular}

\begin{tabular}{|l|l}
\hline Usina Costa Pinto & 20
\end{tabular}

\begin{tabular}{|l|l}
\hline Bairro Tamandupá & 10
\end{tabular}

\begin{tabular}{|l|l}
\hline Igreja de Santa Olímpia & 3,3 \\
\hline
\end{tabular}

\begin{tabular}{|l|l|}
\hline Cooperativa & 3,3 \\
\hline
\end{tabular}

\begin{tabular}{|l|l}
\hline Sindicato em Rio Claro & 6,7 \\
\hline
\end{tabular}

\begin{tabular}{|l|l|}
\hline Tanquinho & 3,3 \\
\hline
\end{tabular}

\begin{tabular}{|l|l|}
\hline ESALQ & 10 \\
\hline Na
\end{tabular}

\begin{tabular}{l|l} 
Na cidade & 6,7
\end{tabular}

\begin{tabular}{|l|l}
\hline Não se manifestou & 30
\end{tabular}

Q.33. Qual seria o melhor horário?

\begin{tabular}{|l|l|}
\hline Diurno & 10 \\
\hline Noturno & 23,3 \\
\hline Sábado & 6,7 \\
\hline Na entre-safra & 33,3 \\
\hline Qualquer horário & 10 \\
\hline Não se manifestou & 16,7 \\
\hline
\end{tabular}

Q.34. Qual a melhor forma de contactá-lo?

\begin{tabular}{|l|l|}
\hline Telefone & 86,7 \\
\hline Pessoalmente & 6,7 \\
\hline Correspondência & 3,3 \\
\hline Associação de Bairro & 3,3
\end{tabular}

Q.35. Você gostaria de receber mais informações sobre:

\begin{tabular}{l|l}
\hline Legislação Florestal & 23,2
\end{tabular}

(continua) 


\begin{tabular}{|l|l|}
\hline Questões & Total de Respostas (\%) \\
\hline Q.35. (continuação) & \\
\hline Lei sobre caça e pesca & 1,8 \\
\hline Licenciamento & 1,8 \\
\hline Alternativas econômicas & 17,9 \\
\hline Programas de auxílio & 14,3 \\
\hline Tecnologia de plantio & 8,9 \\
\hline Proteção à Natureza & 14,3 \\
\hline Conservação do solo & 1,8 \\
\hline Como valer para todos (denúncias) & 3,6 \\
\hline Diversos assuntos & 7,1 \\
\hline Não tenho interesse & 5,4 \\
\hline
\end{tabular}

Quadro 4 - Resultados do questionário aplicado aos proprietários rurais.

Utilizou-se como critério para a categorização, o agrupamento das respostas mais freqüentes.

As respostas na íntegra, podem ser encontradas na Tabela de Resultados dos Questionários, em anexo (Anexo C).

Conforme elucidado no item 5.3 da metodologia, as entrevistas foram realizadas em duas etapas diferentes. A primeira consistiu na aplicação de 16 questionários pela pesquisadora e a Segunda, contou com o auxílio de estudantes na aplicação de outros 14 questionários. Com o objetivo de comparar os resultados das entrevistas nestes dois momentos, a construção dos gráficos de respostas foi efetuada separando os dois grupos de respostas. 


\subsubsection{Gráficos de respostas obtidas nos questionários aplicados pela pesquisadora e pelos estudantes de graduação}

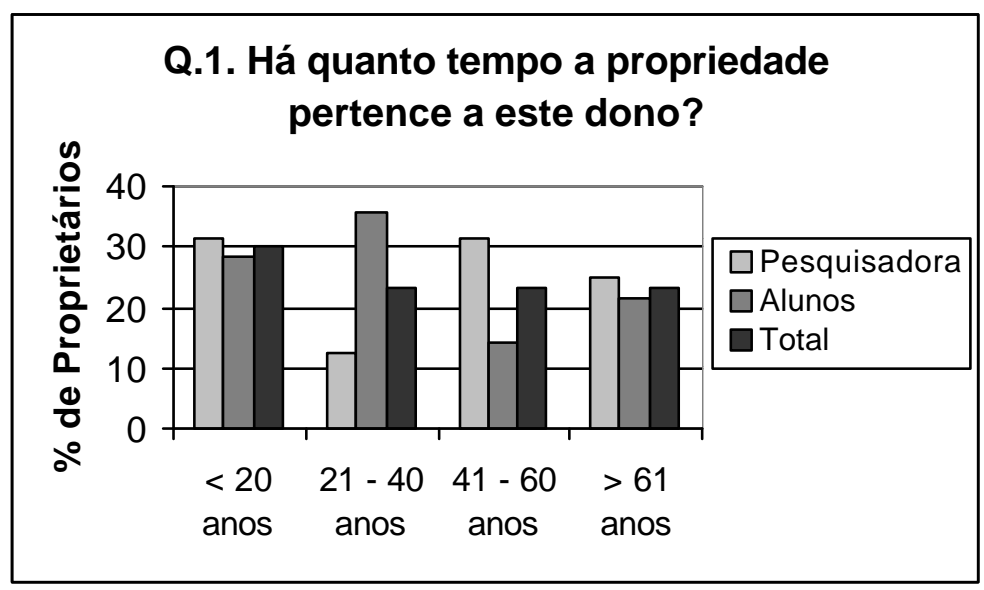

Figura 9 - Respostas da questão 1.

Este primeiro gráfico demonstra que a maioria dos proprietários entrevistados, possui suas propriedades a menos de 20 anos. Este fator é importante quando pretende-se diferenciar o comportamento daqueles que nasceram na propriedades, dos que a adquiriram através da compra.
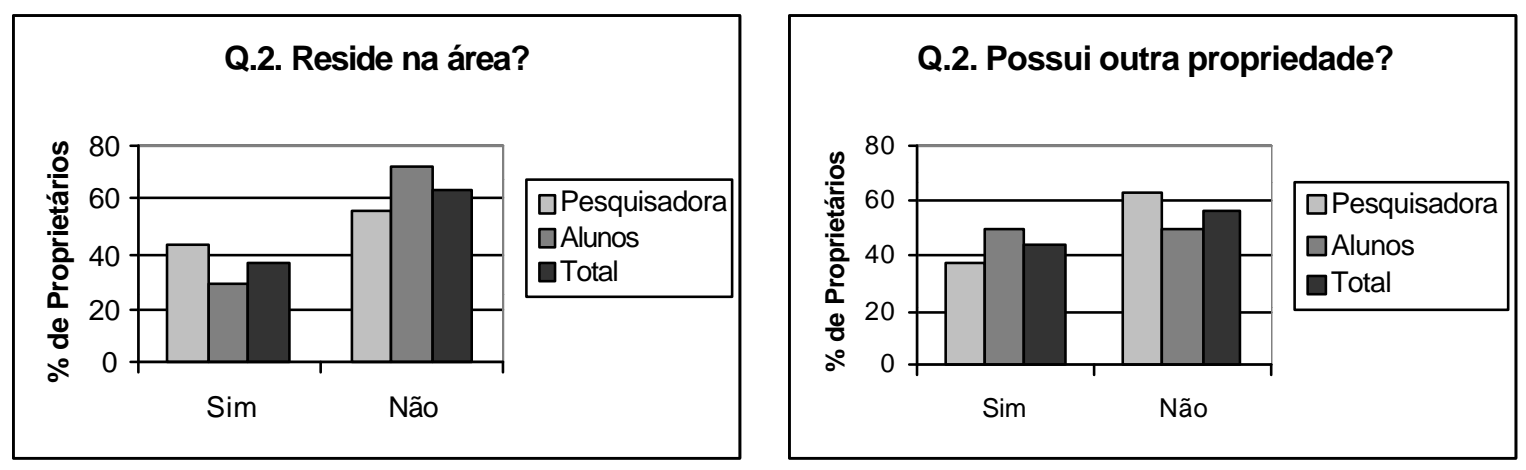

Figura 10 - Respostas da questão 2.

Observa-se que grande parte dos proprietários não reside na área (63\%). Com base neste dado, é possível por exemplo, definir quantos são os pequenos proprietários rurais da região (que segundo a legislação atual, Medida Provisória que altera o Código Florestal, devem residir na propriedade). 


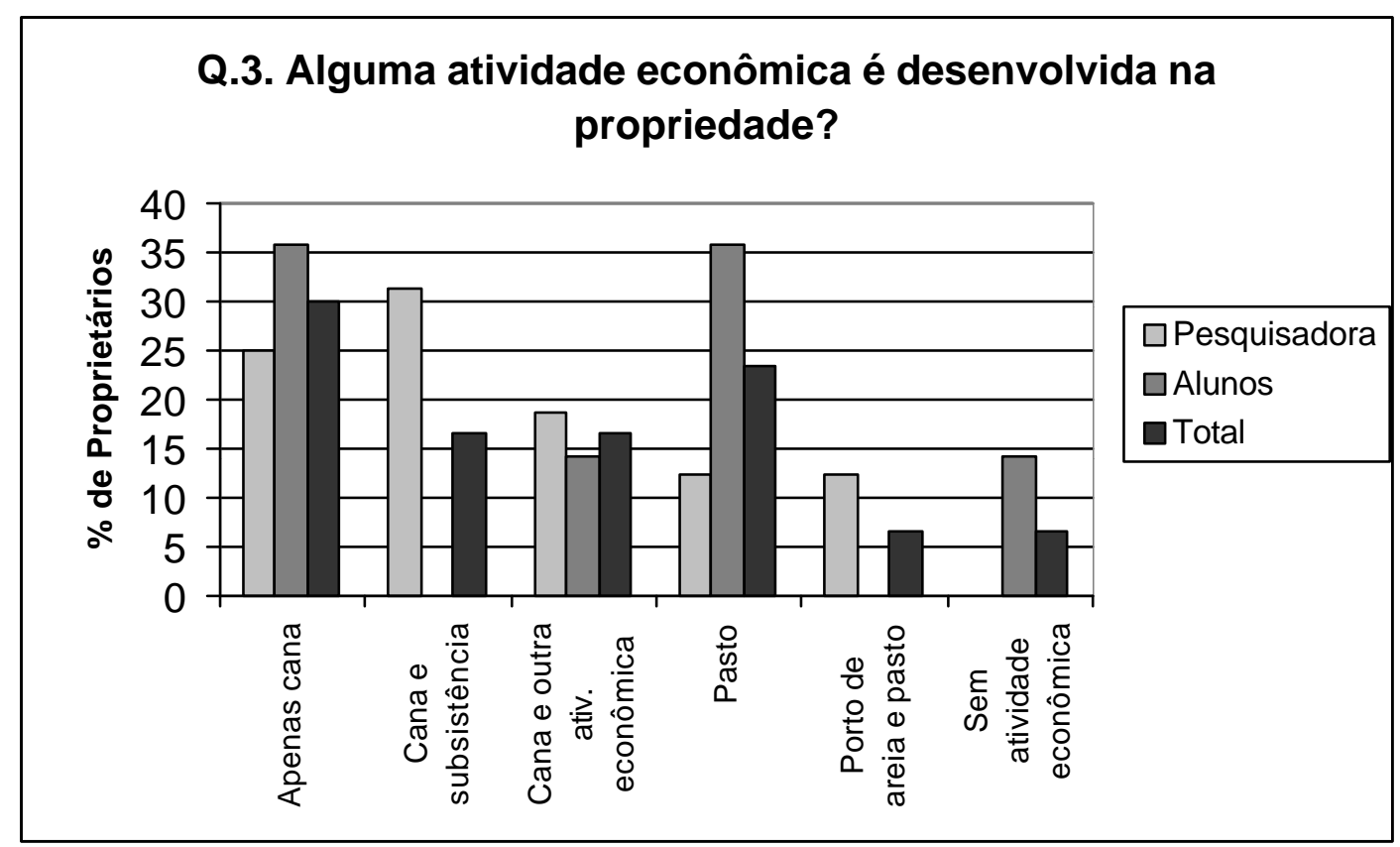

Figura 11 - Respostas da questão 3.

A maior parte dos entrevistados produz cana-de-acúcar (somando 63\% dos questionados). Em seguida vem o pasto ( que soma $30 \%$ ). Esta sequência de culturas coincide com aquela encontrada na literatura, embora os valores sejam diferentes.

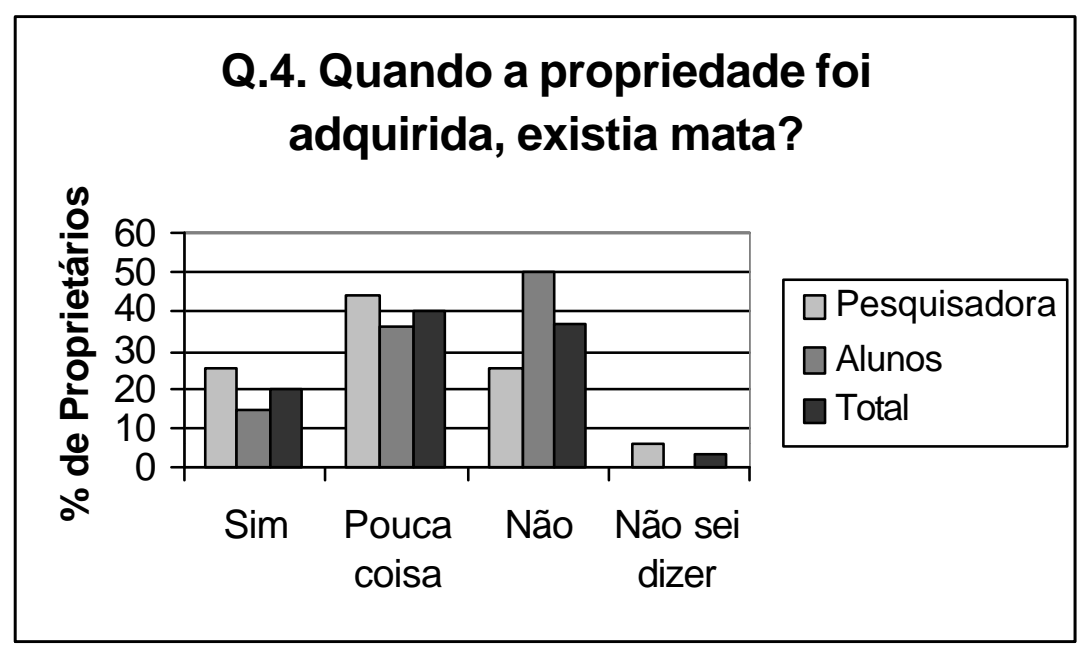

Figura 12 - Respostas da questão 4.

Um grande número de proprietários afirma ter encontrado suas propriedades com pouca ou nenhuma mata no momento em que as adquiriram. Obs.: O objetivo da presente pesquisa não foi verificar a veracidade destes dados (o que poderia ser feito 
analisando antigas fotos aéreas e imagens de satélite), mas sim, saber como os proprietários se colocam frente a uma pergunta como esta.

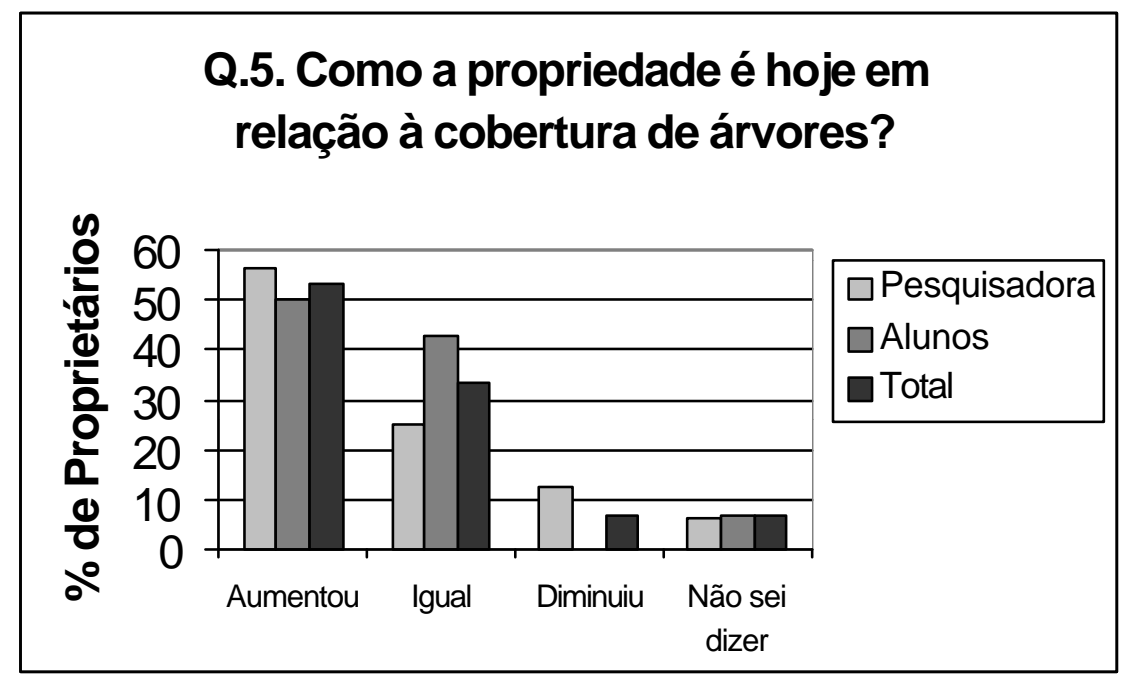

Figura 13 - Respostas da questão 5.

A maioria diz que aumentou a cobertura de árvores, principalmente pelo fato de terem cessado o cultivo em áreas de preservação permanente.

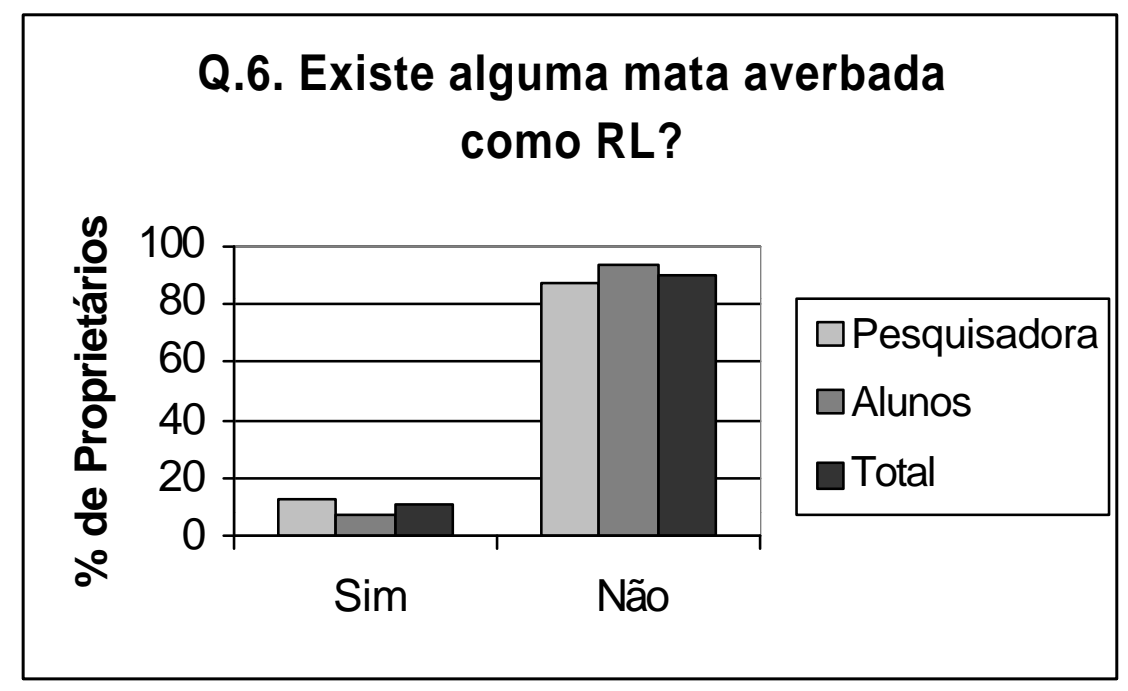

Figura 14 - Respostas da questão 6.

Confirmando a informação fornecida pelo DEPRN, a grande maioria das propriedades não possui reserva legal florestal averbada. 


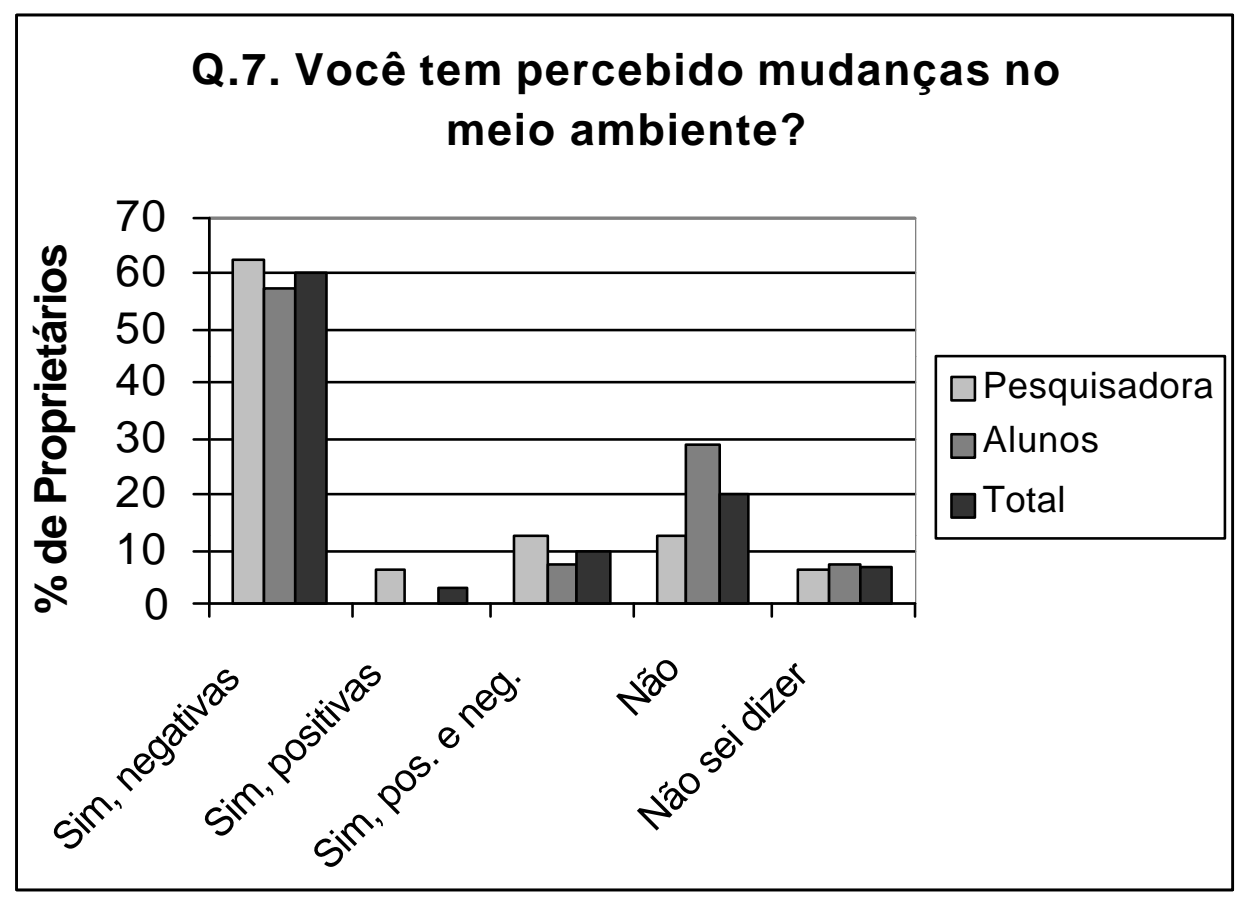

Figura 15 - Respostas da questão 7.

A maior parte das mudanças no ambiente percebida pelos entrevistados, são negativas. Eles reclamam do calor excessivo, da ausência de chuvas e das tempestades esporádicas, do enfraquecimento do solo, etc. Apenas algumas pessoas notaram uma melhoria na qualidade de água do Rio Corumbataí, com a diminuição de poluentes despejados pela Usina Costa Pinto.

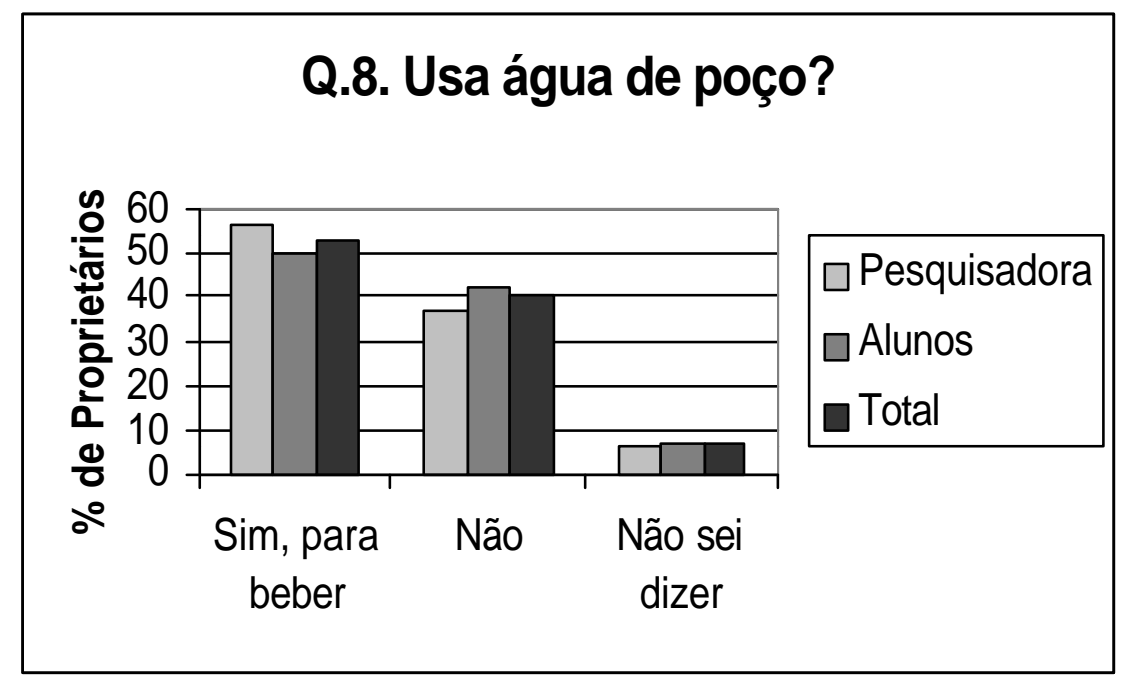

Figura 16 - Respostas da questão 8.

Muitos proprietários utilizam água de poço em suas propriedades. 


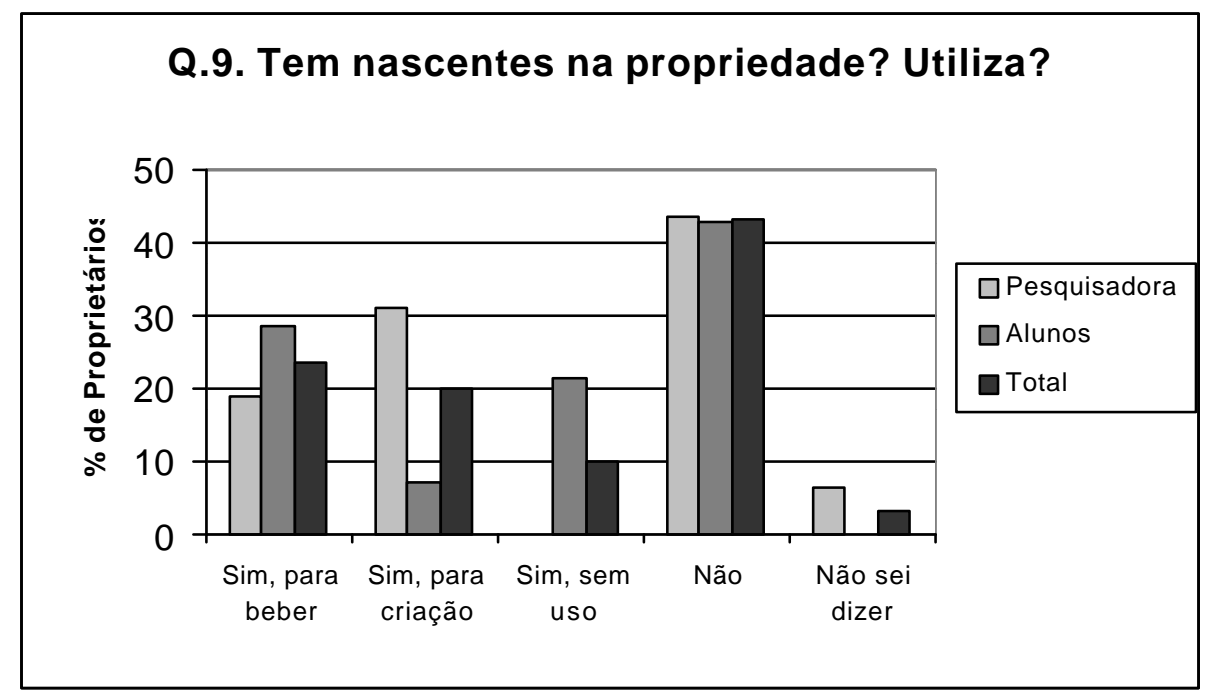

Figura 17- Respostas da questão 9.

A maior parte dos entrevistados declara não possuir nascentes em suas propriedades, dado este, que não coincide com mapas da região (O mapa da rede hídrica pode ser observado no Anexo D).

Este fato pode demonstrar algum temor em declarar a existência de nascentes, pelo possível temor em relação à legislação ambiental, ou alienação em relação às características de sua propriedade.

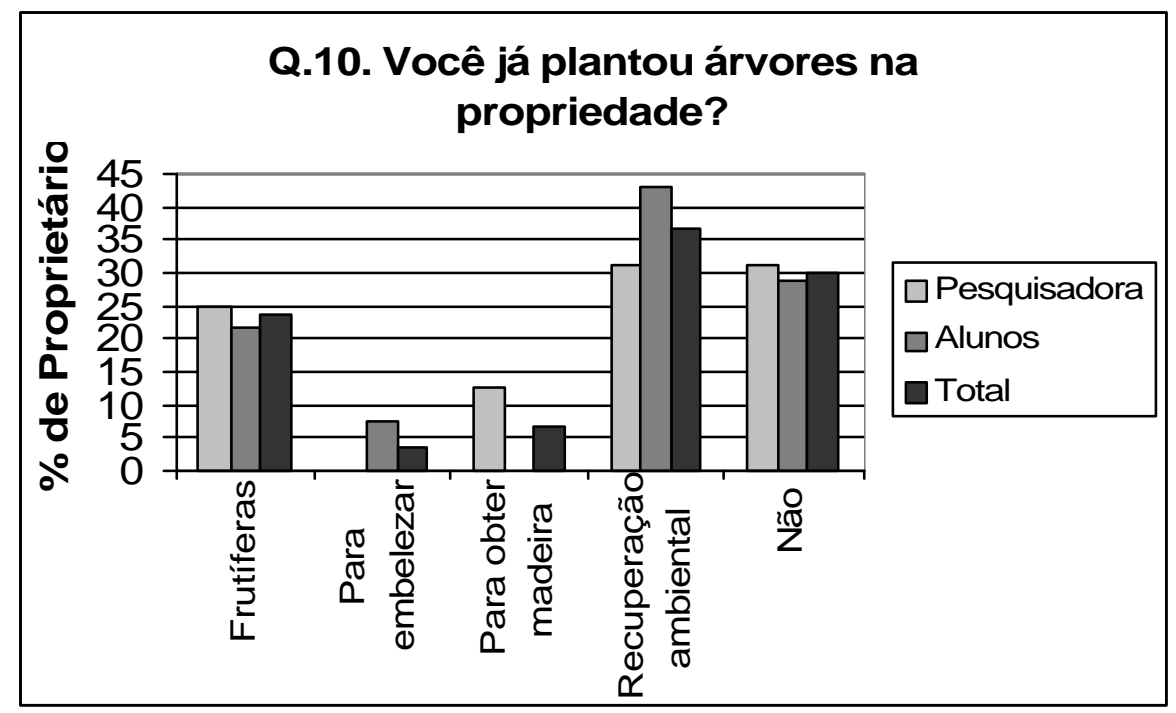

Figura 18 - Respostas da questão 10.

A maioria dos proprietários declara já ter plantado árvores, principalmente com o intuito de promover a recuperação ambiental. 


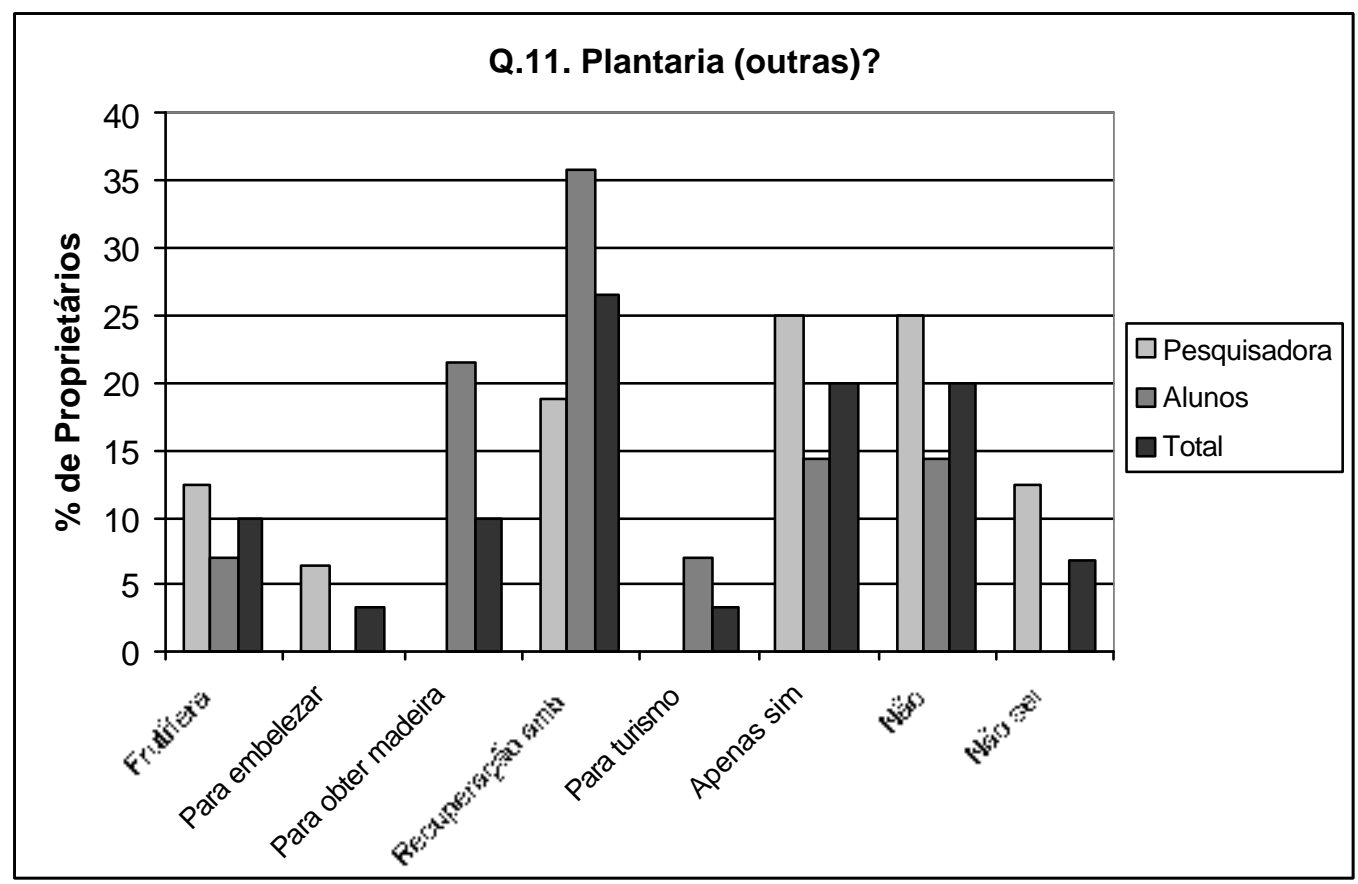

Figura 19 - Respostas da questão 11.

Muitos declaram ainda, que plantariam mais árvores visando a recuperação ambiental, porém, vale ressaltar que o número daqueles que não plantariam, não é baixo ( $\cong 20 \%$ dos entrevistados).

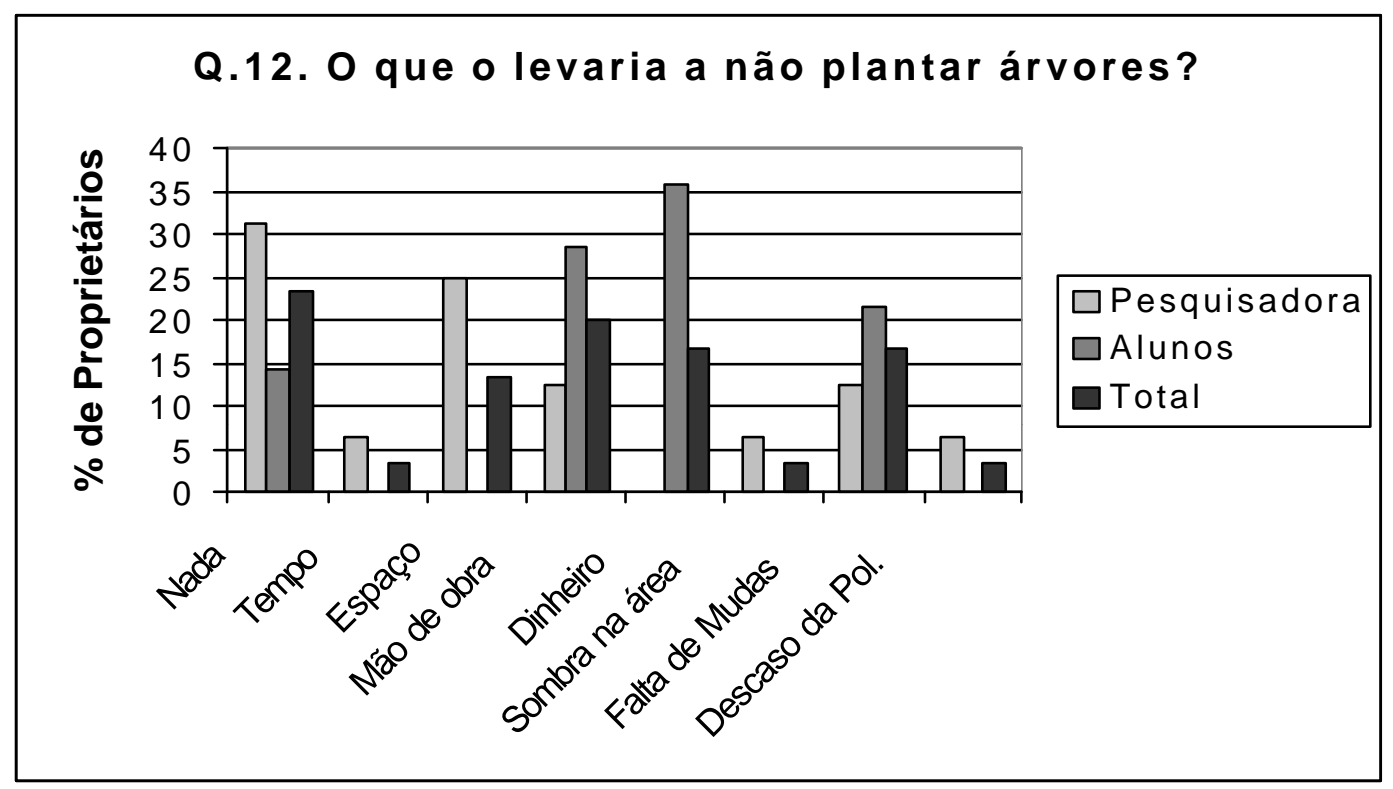

Figura 20 - Respostas da questão 12.

Dentre os motivos que poderiam levar proprietários a não plantar árvores, destacam-se a falta de mão-de-obra, dinheiro e mudas adequadas. 


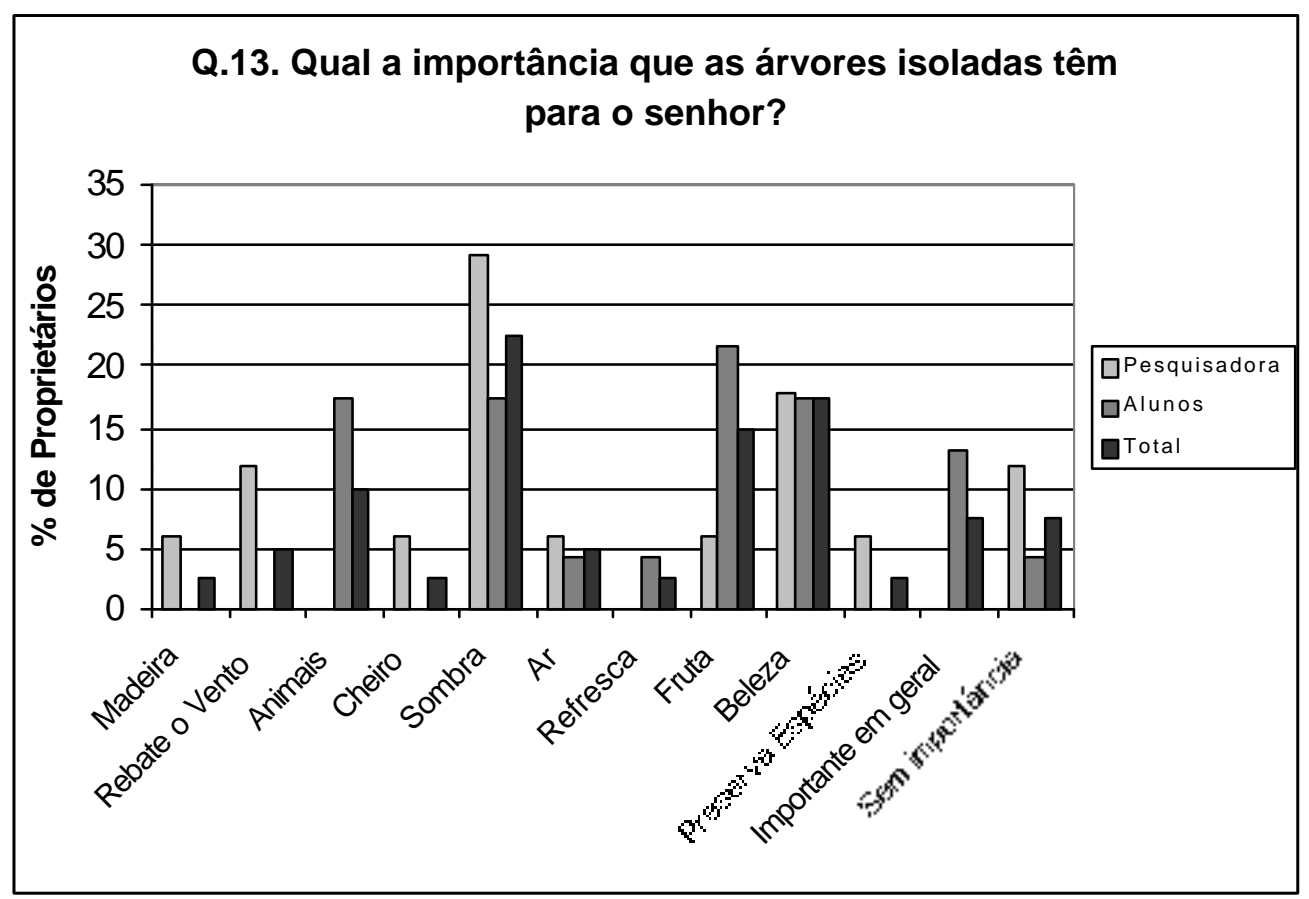

Figura 21 - Respostas da questão 13.

Para muitos entrevistados, as árvores espalhadas pela propriedade (que não formam matas) são importantes para dar sombra, embelezar a área e fornecer frutos, etc. A valorização dada a estas árvores, demonstra que muitos proprietários possuem afetividade pelas árvores. Valor este, que poderá/deverá ser resgatado na relação dos mesmos também com as florestas.

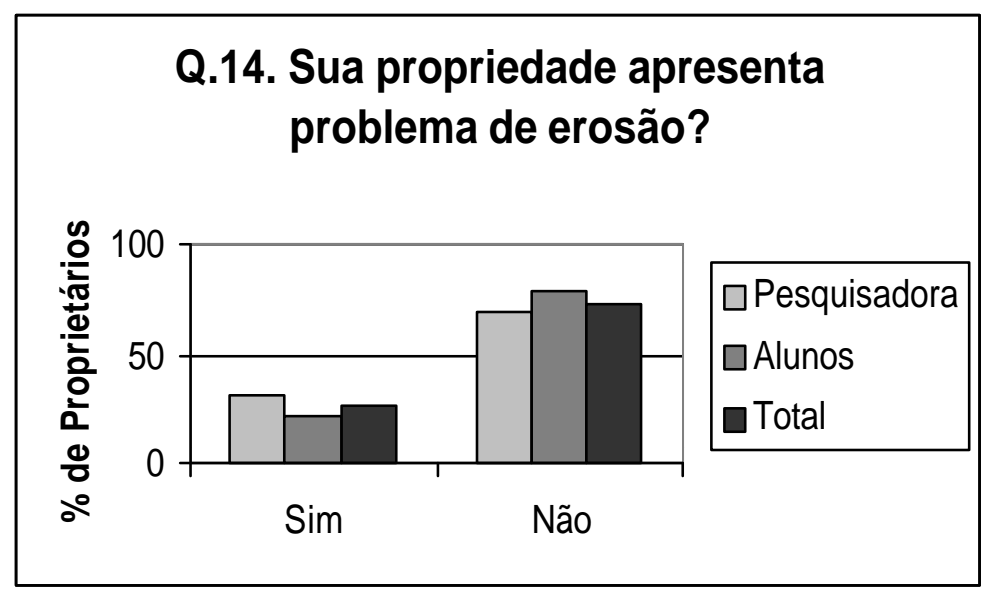

Figura 22 - Respostas da questão 14.

Com relação à erosão, a maioria declara estar controlando as ocorrências seguindo orientações da Usina Costa Pinto e fazendo curvas de nível. Nenhum 
proprietário declarou enfrentar problemas com deslizamentos de terra próximos aos rios.

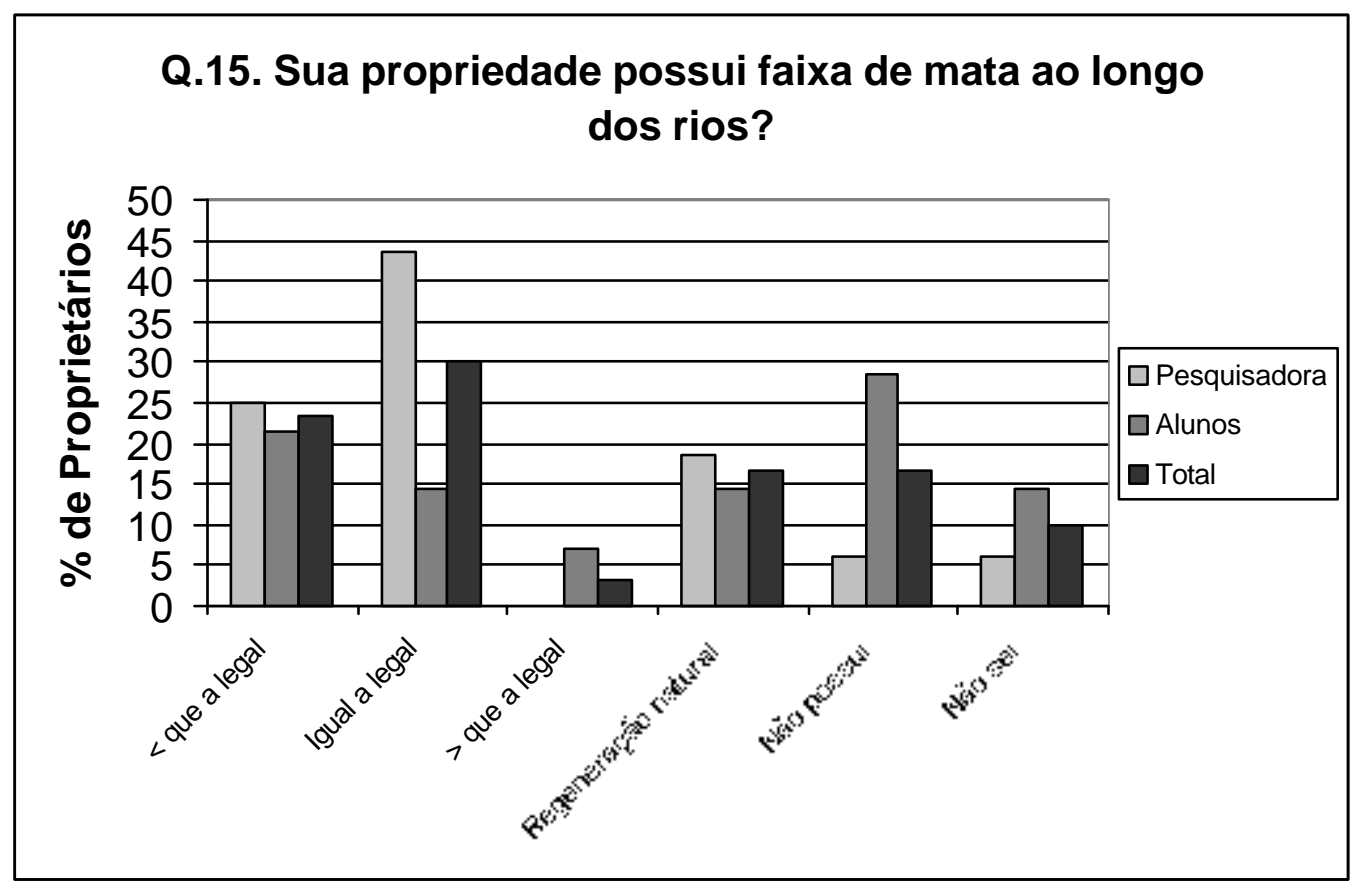

Figura 23 - Respostas da questão 15.

Muitos proprietários afirmam possuir a faixa de mata no entorno dos rios, com as medidas determinadas por lei, porém, muitos se confundem sobre quais seriam estas medidas. Há novamente a demonstração de certo receio ao responder perguntas que podem comprometê-los de alguma forma, mesmo havendo sempre a explicação de que não há qualquer intenção de denúncia por parte da pesquisa.

O mapa de cobertura florestal da região, produzido pelo IPEF / SEMAE 2001 (Anexo E), demonstra também alguma incoerência entre as respostas dadas pelos proprietários, e a realidade encontrada na Microbacia Hidrográfica. 


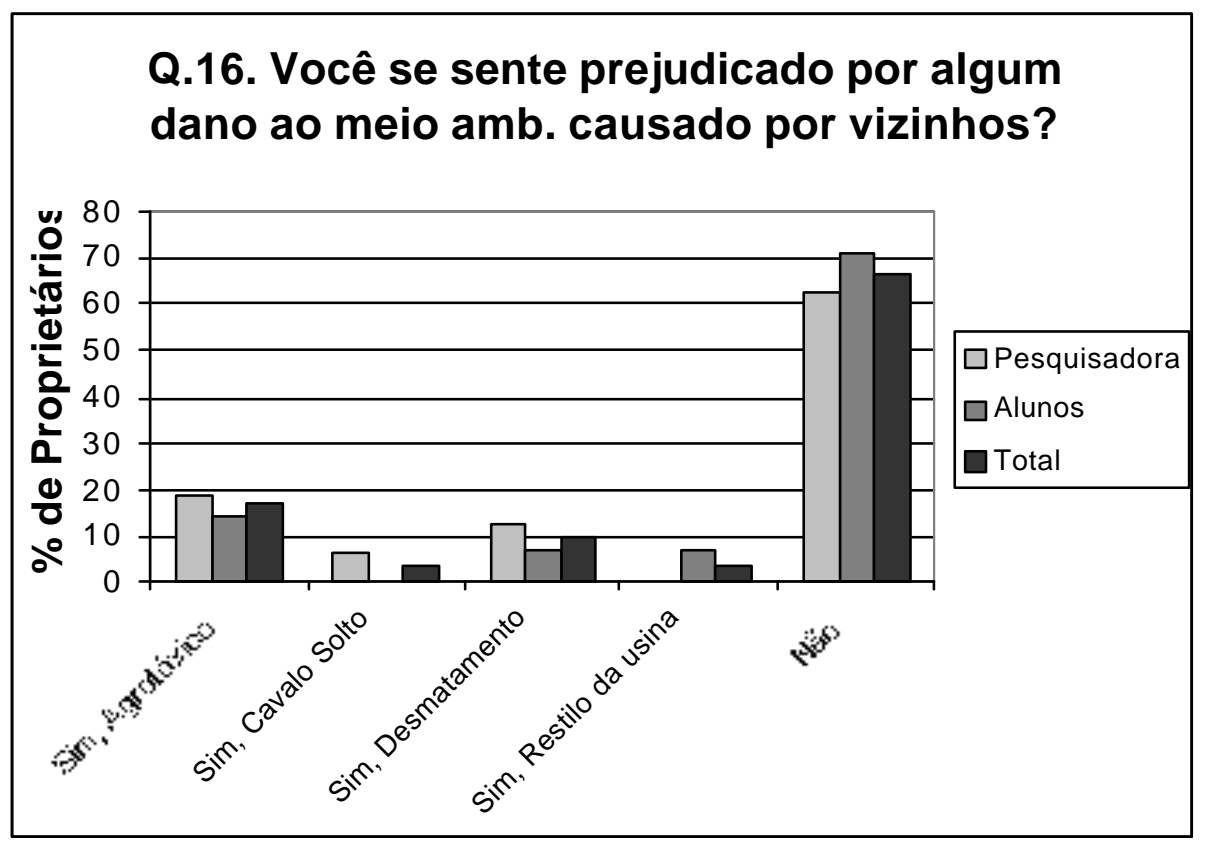

Figura 24 - Respostas da questão 16.

A maior parte dos proprietários não se sente prejudicado por danos ambientais causados por vizinhos, embora muitos declarem ser mais esclarecidos do que os outros e afirmem que o não cumprimento da legislação em propriedades ao redor, justifica sua própria omissão em relação às leis.

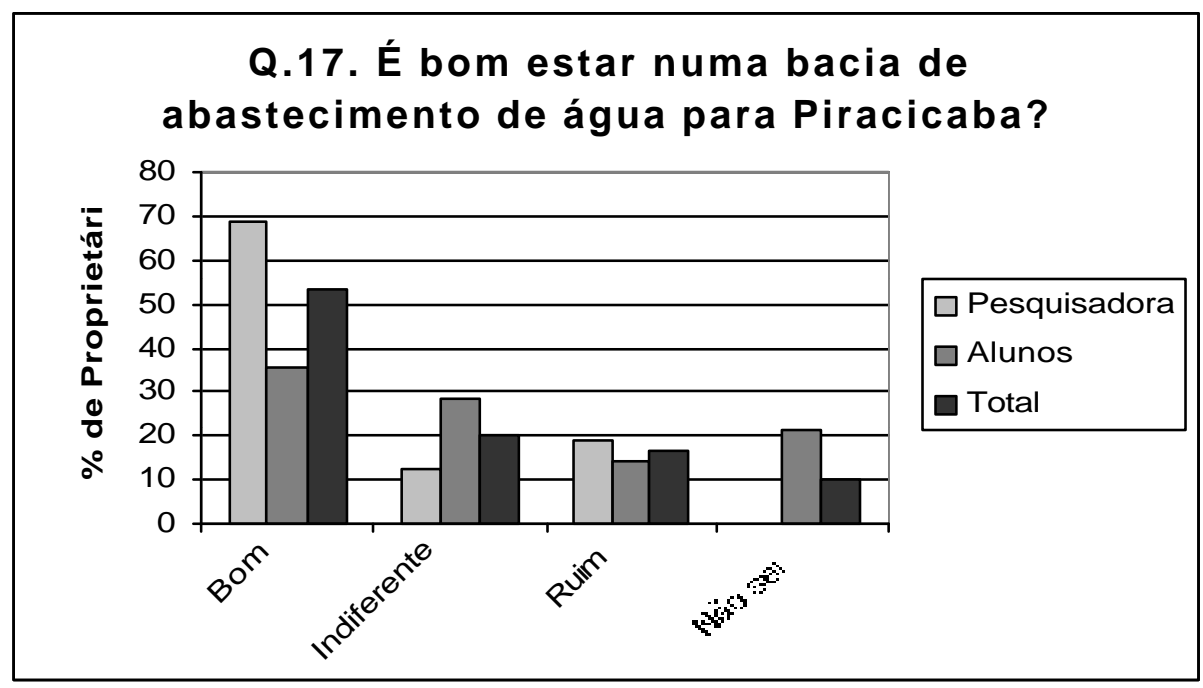

Figura 25 - Respostas da questão 17.

Diversos proprietários afirmam ser melhor estar inserido numa Bacia Hidrográfica que abasteça a cidade, mesmo que isto desperte maior atenção dos 
órgãos fiscalizadores, do que não ter água na propriedade. Alguns ainda vislumbram benefícios que esta condição (a de existir água nas proximidades) pode trazer para eles no futuro (valorização econômica, maior qualidade da água,...).

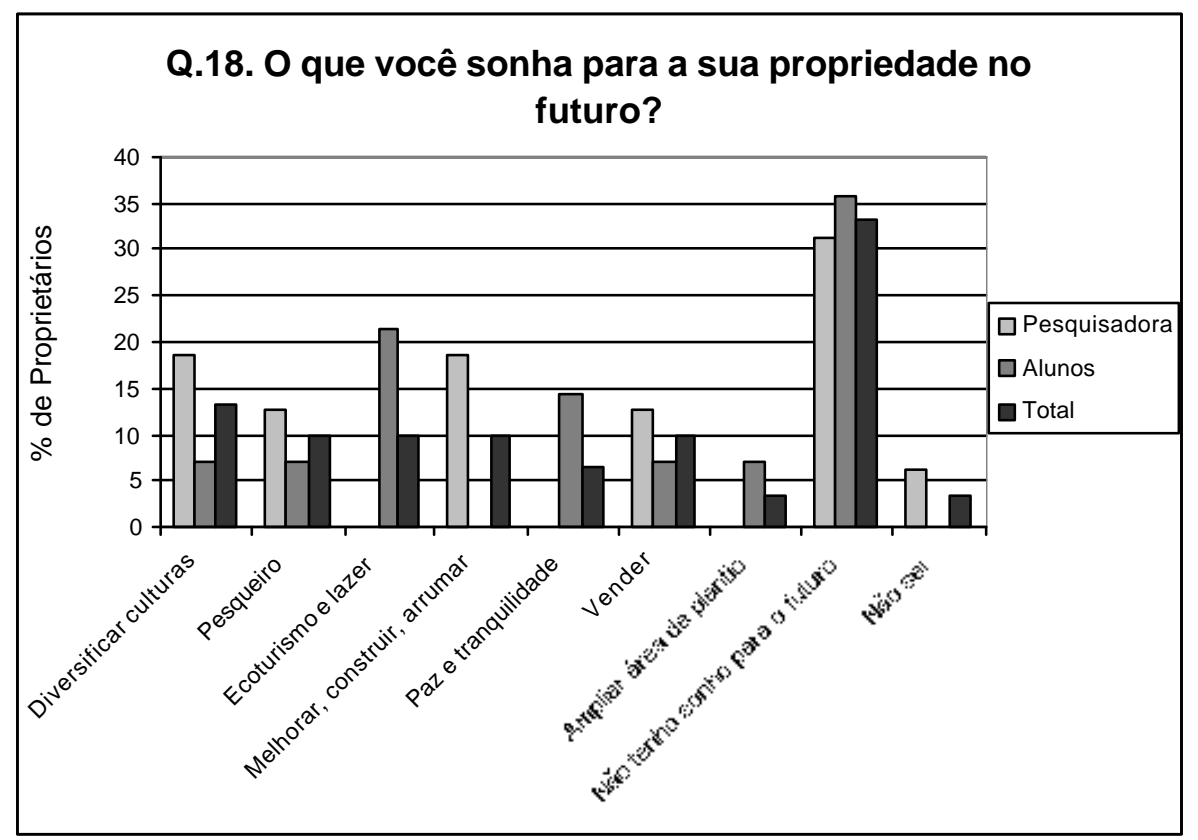

Figura 26 - Respostas da questão 18.

A ausência de sonhos para o futuro, declarada por grande parte dos proprietários rurais entrevistados, confirma a observação do presidente do Sindicato dos Trabalhadores Rurais, que afirma ser grande o desânimo no setor. Os problemas financeiros que se prolongam por vários anos e a grande migração para a cidade, geram uma ausência de esperança e perspectivas para o futuro dos poucos que permanecem no campo. 


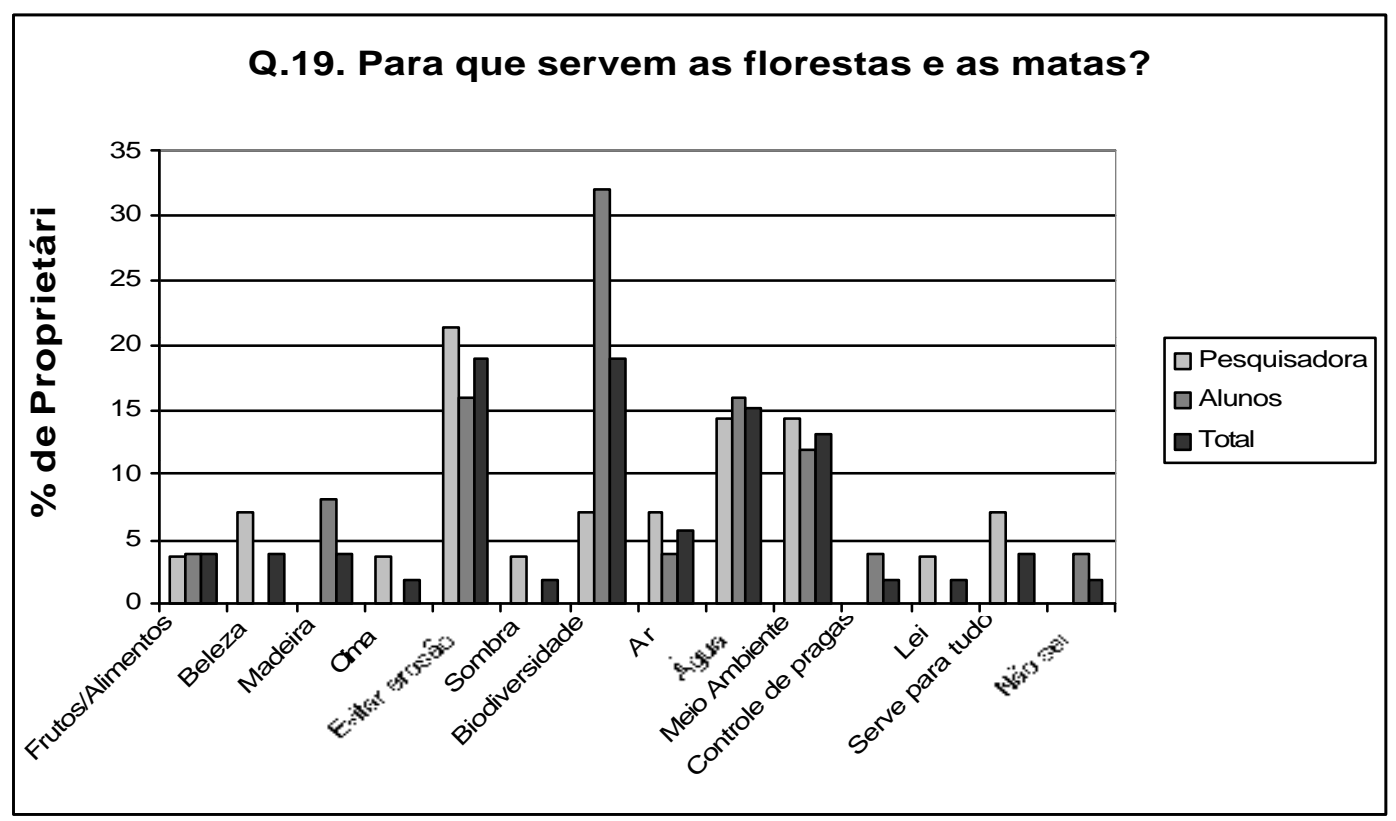

Figura 27 - Respostas da questão 19.

Muitos proprietários acreditam que as principais funções das matas são garantir a diversidade de animais e plantas, e evitar a erosão. Em seguida, vem a proteção da água e do meio ambiente como um todo.

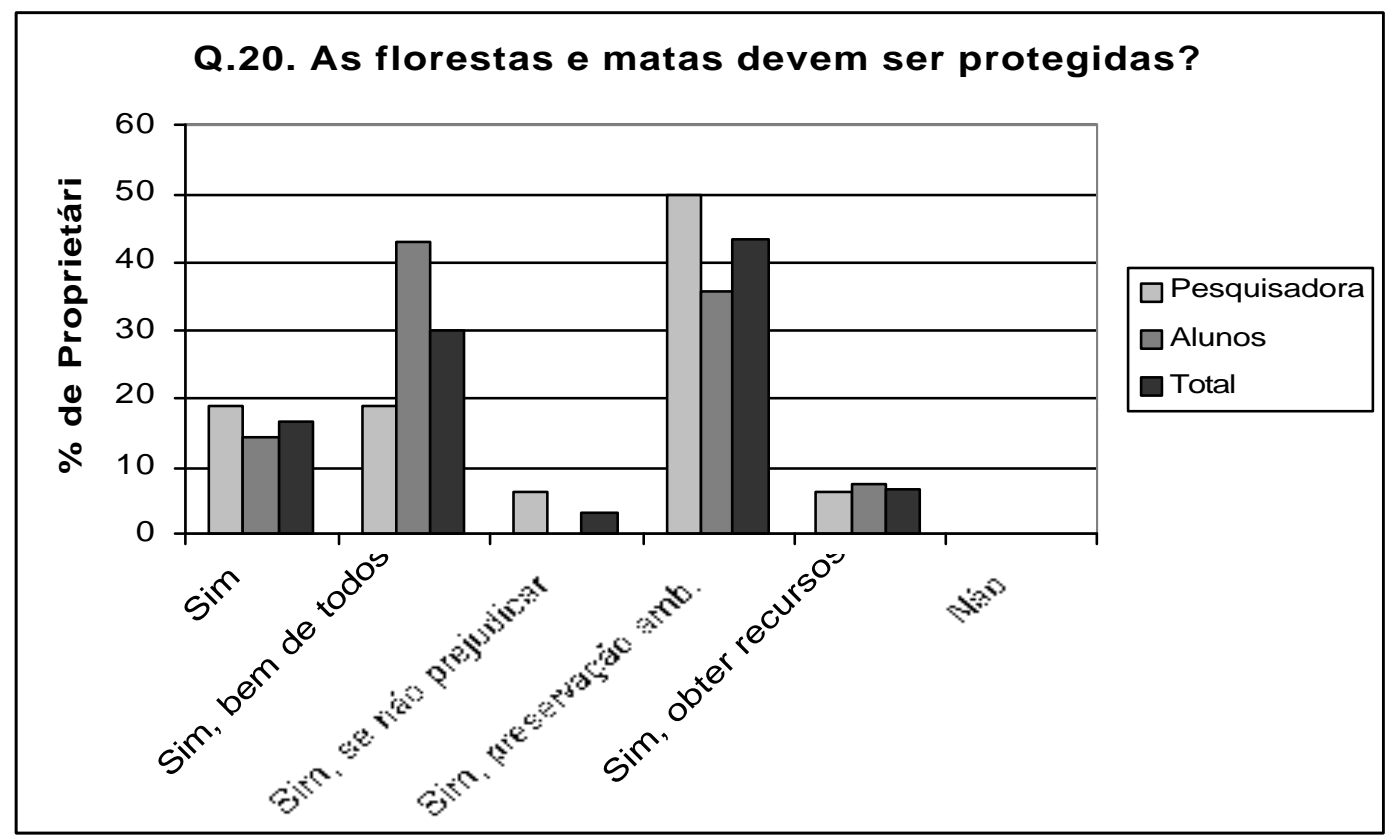

Figura 28 - Respostas da questão 20.

A maioria dos proprietários apoia a proteção das florestas para a preservação do meio ambiente e para assegurar o bem de todos. 


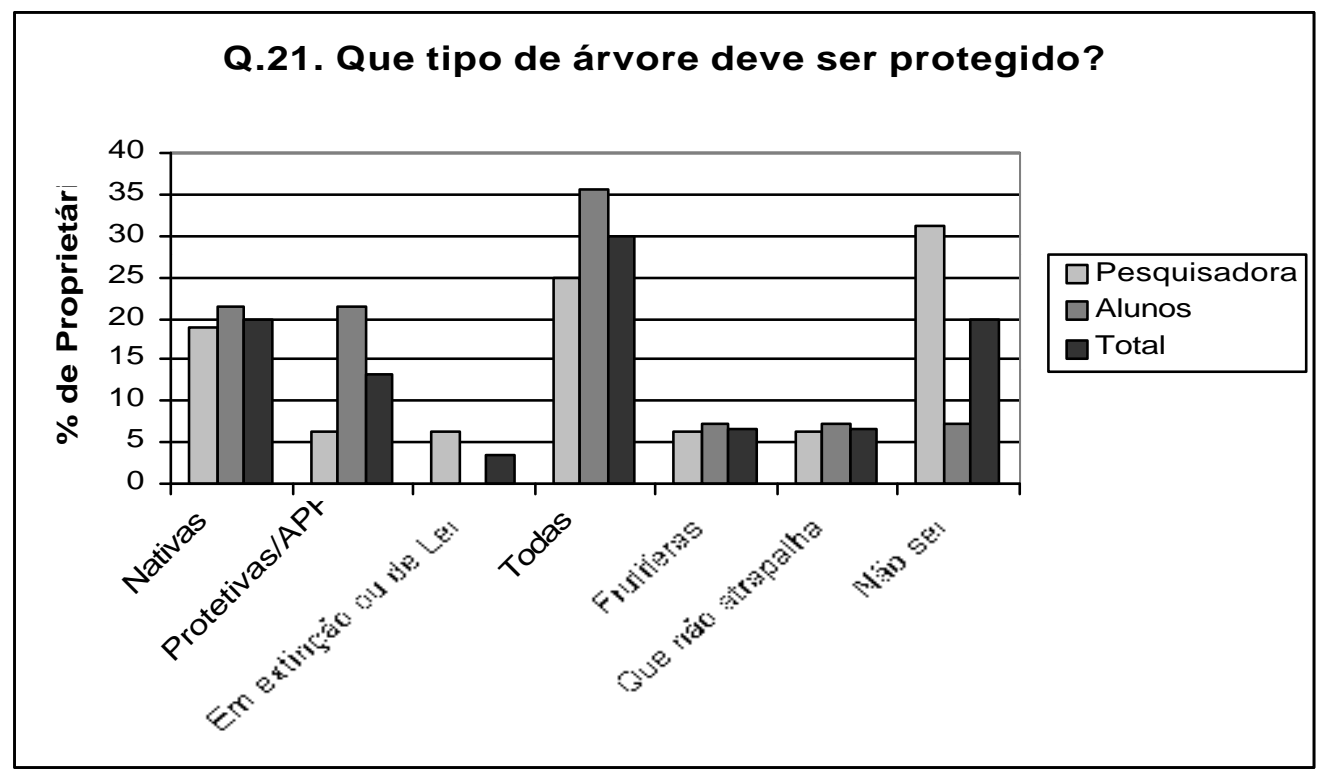

Figura 29 - Respostas da questão 21 (A).

Para muitos dos entrevistados, todos os tipos de árvores devem ser protegidos, principalmente as árvores nativas.

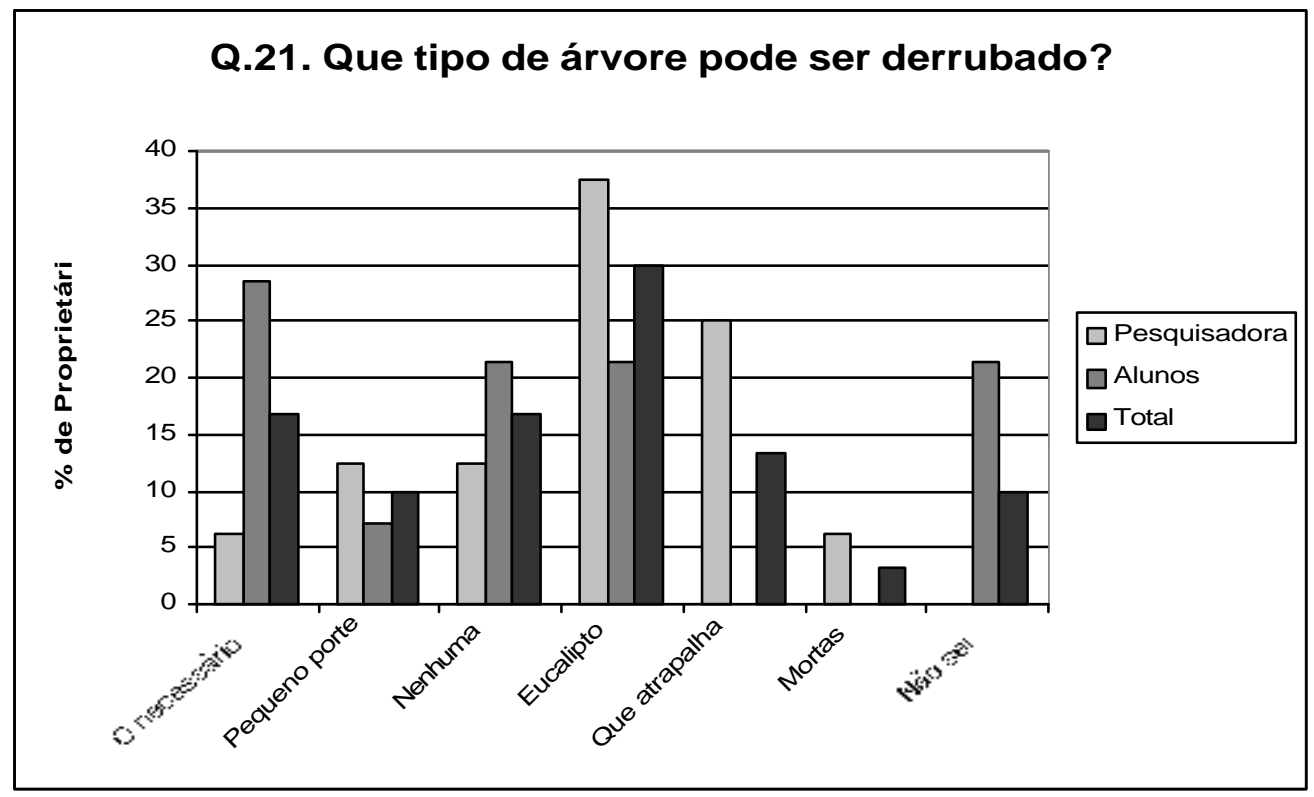

Figura 30 - Respostas da questão 21 (B).

Os proprietários afirmam de deve-se derrubar Eucaliptos plantados para essa finalidade, e outras árvores apenas quando for necessário. 


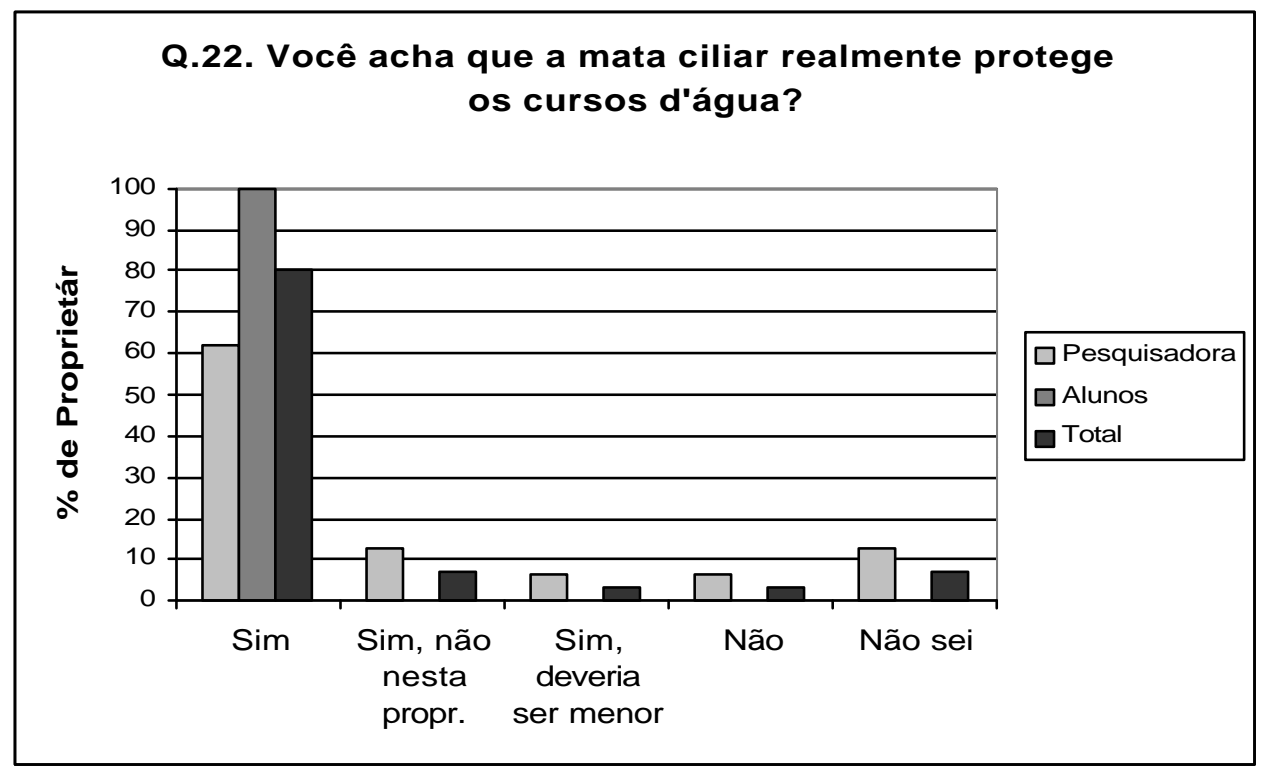

Figura 31 - Respostas da questão 22.

A maior parte dos proprietários acredita que a mata ciliar realmente protege os cursos, alguns porém, afirmam que isto não acontece em suas propriedades. Esta declaração soa como uma tentativa de se esquivar da obrigação legal de destinar estas áreas à preservação permanente.

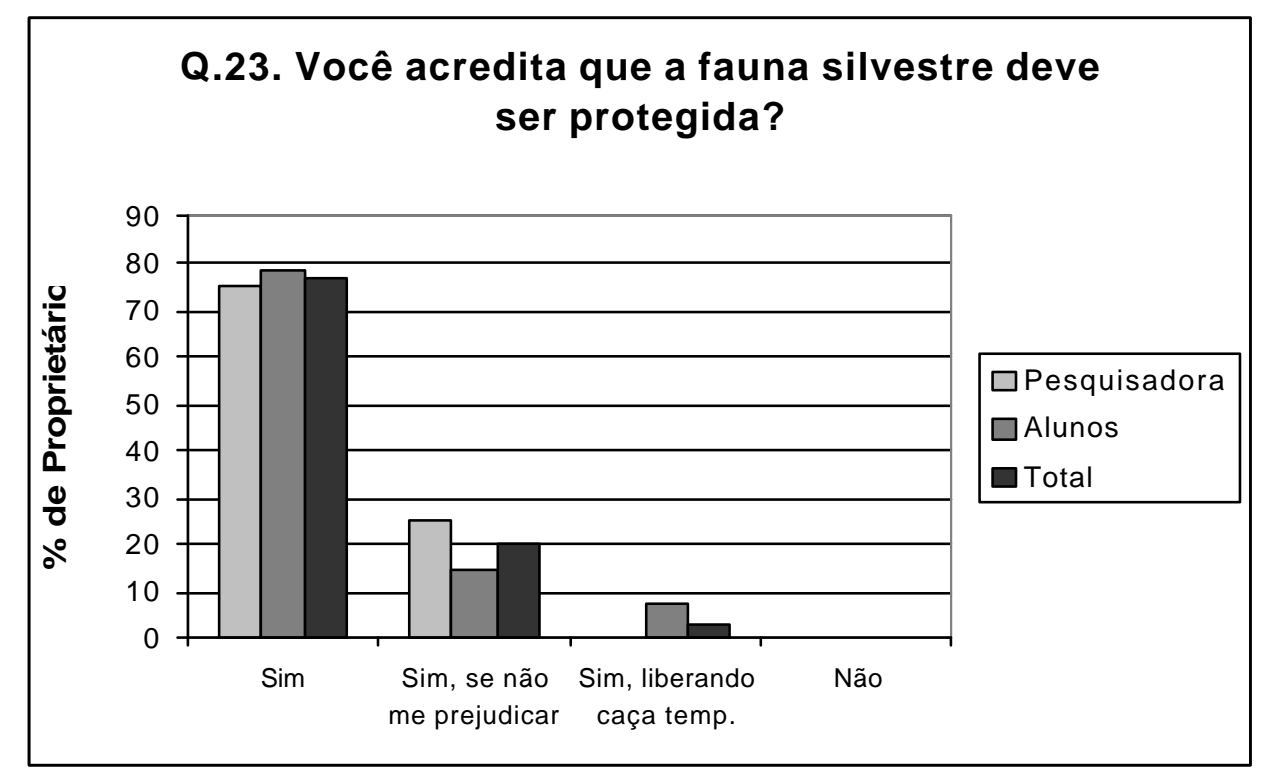

Figura 32 - Respostas da questão 23.

Para os entrevistados, a fauna silvestre deve ser protegida, porém, alguns impõe a condição de que ela não os prejudique. 


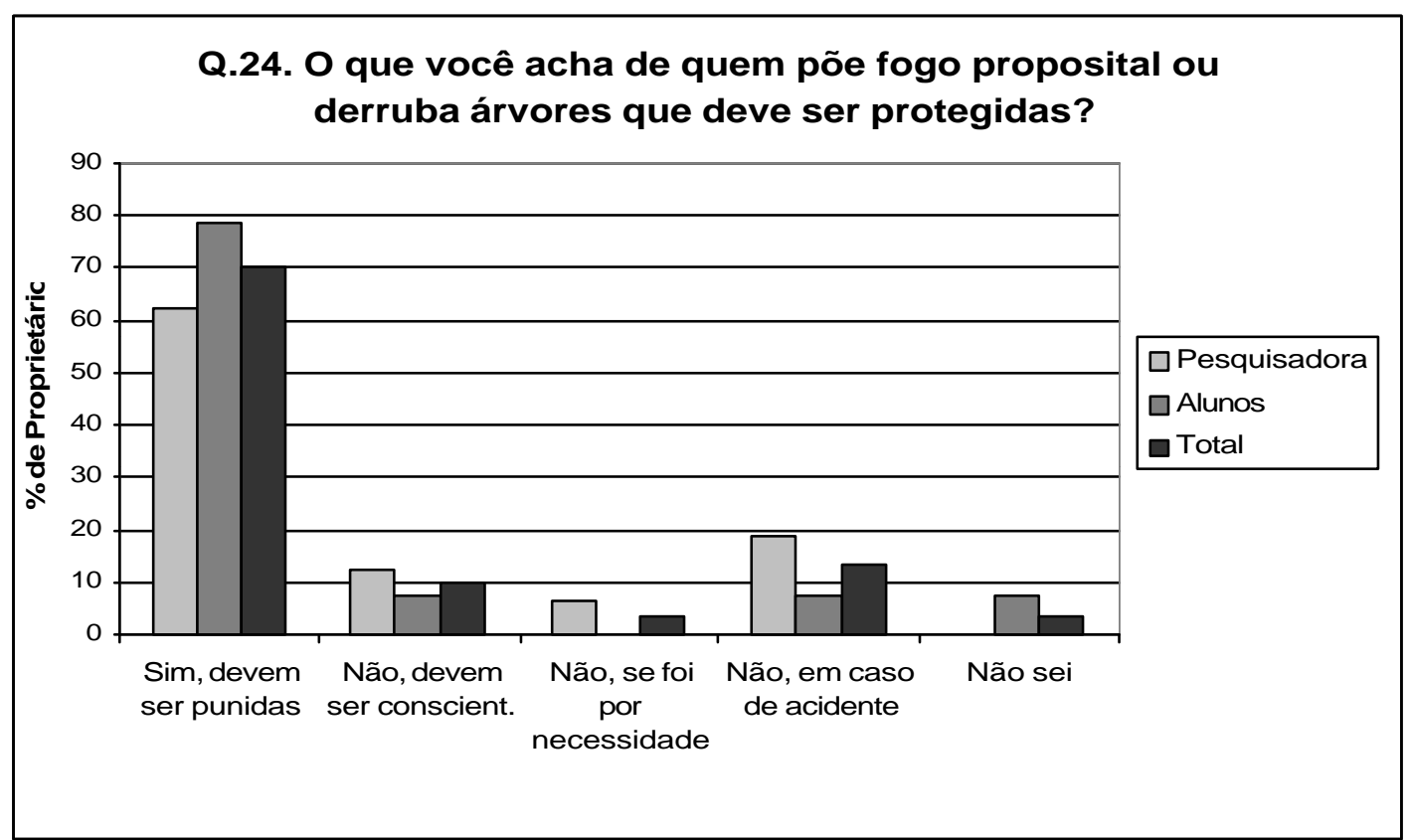

Figura 33 - Respostas da questão 24.

Nesta questão, que busca saber a opinião dos entrevistados sobre alguns dispositivos da legislação ambiental, nota-se que a grande maioria concorda com a punição para determinadas infrações prejudiciais ao meio ambiente.

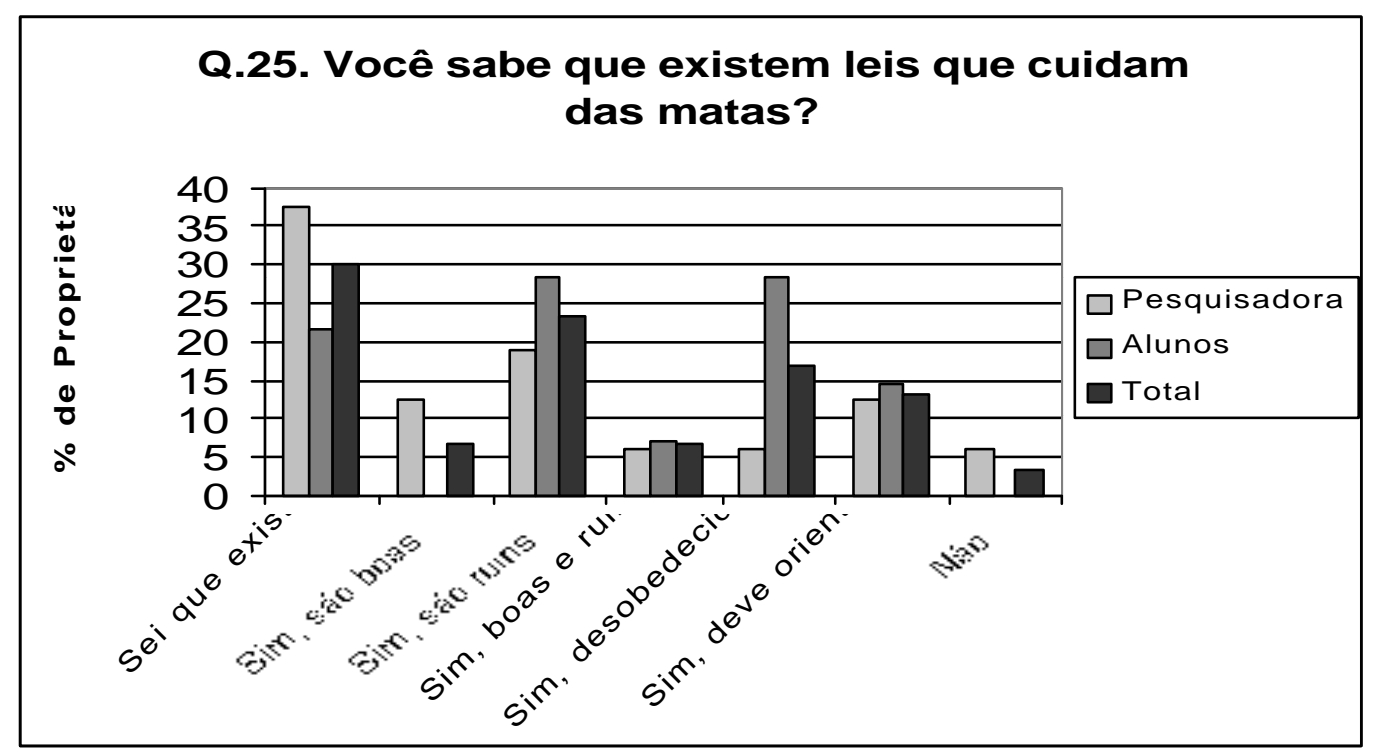

Figura 34 - Respostas da questão 25.

Questionados sobre o conhecimento que possuem das leis que protegem a Natureza, a maioria dos entrevistados declarou saber da existência das mesmas, porém, alegaram desconhecer seu conteúdo. 


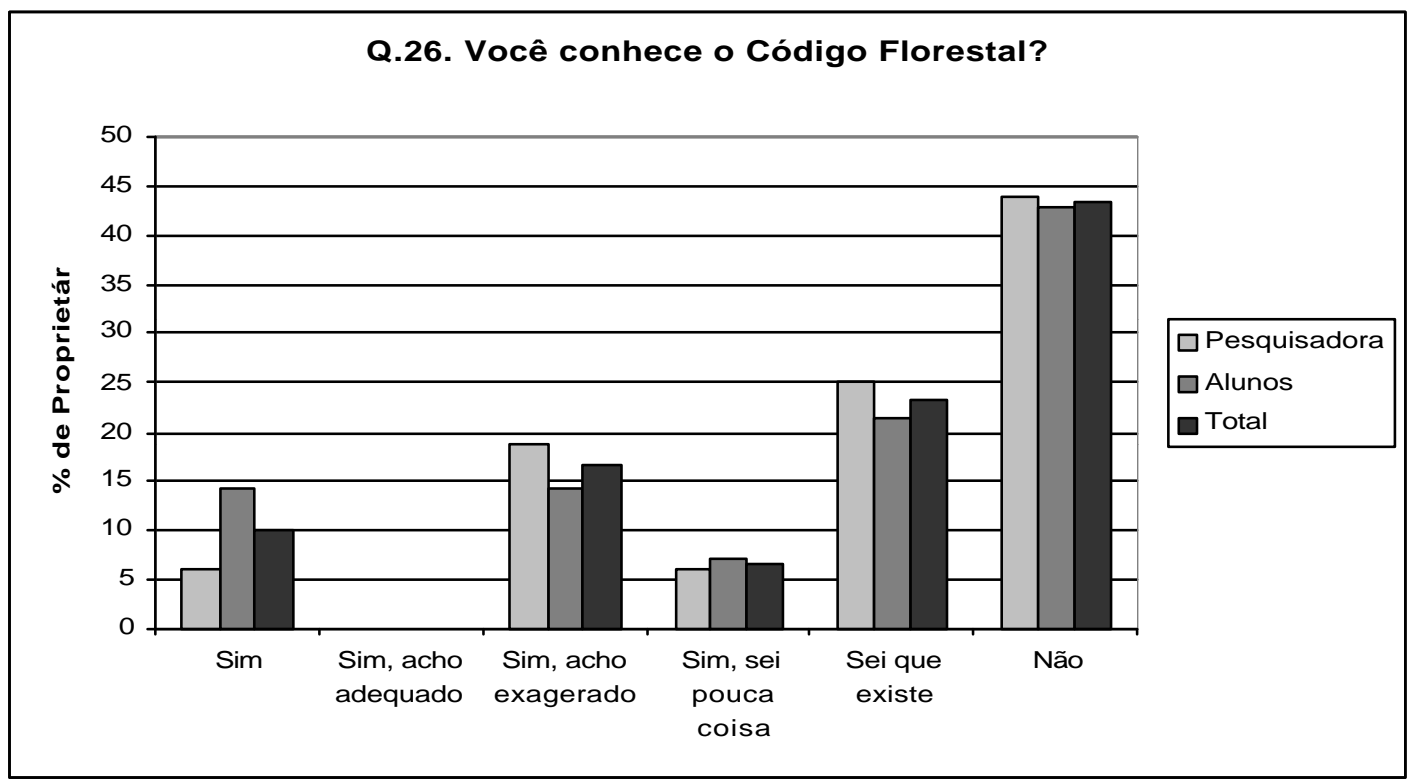

Figura 35 - Respostas da questão 26.

Com relação ao Código Florestal, não há grandes diferenças da questão anterior: a maior parte dos entrevistados declaram não conhecêlo.

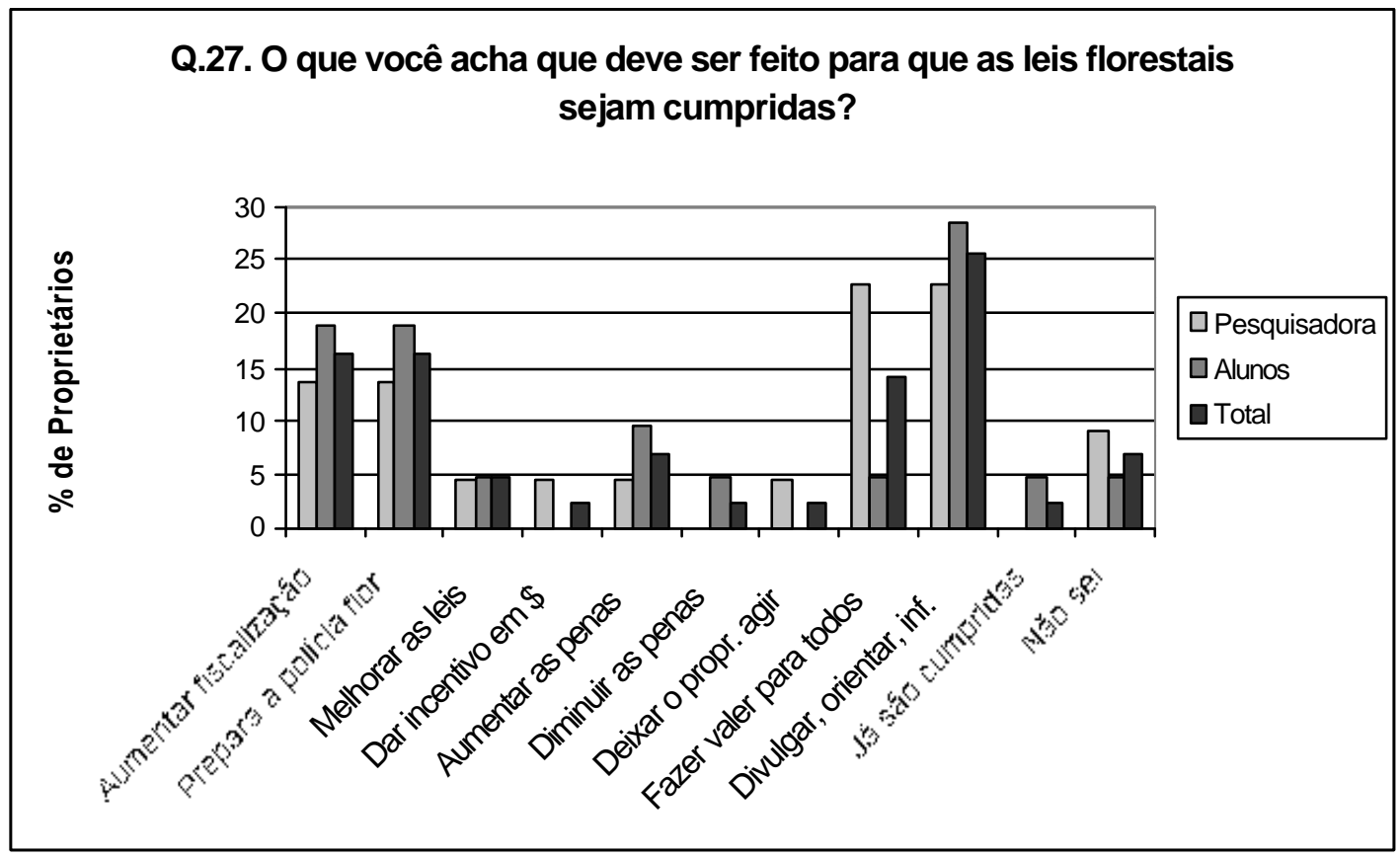

Figura 36 - Respostas da questão 27.

Muitos dos proprietários entrevistados acreditam que divulgando melhor as leis, aumentando a fiscalização e capacitando os policiais florestais para instruir ao invés de multar, as leis passarão a ser cumpridas de forma mais efetiva. 


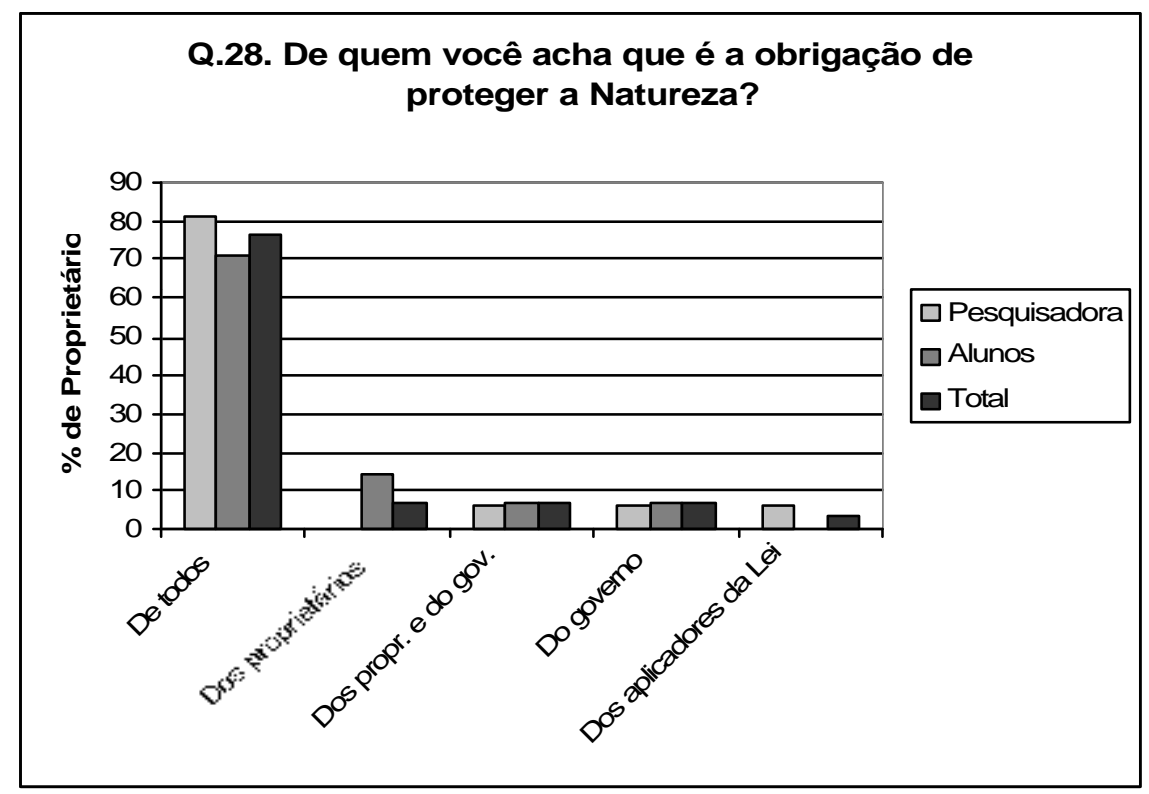

Figura 37 - Respostas da questão 28.

Todos tem obrigação de proteger a Natureza, segundo a maioria dos entrevistados.

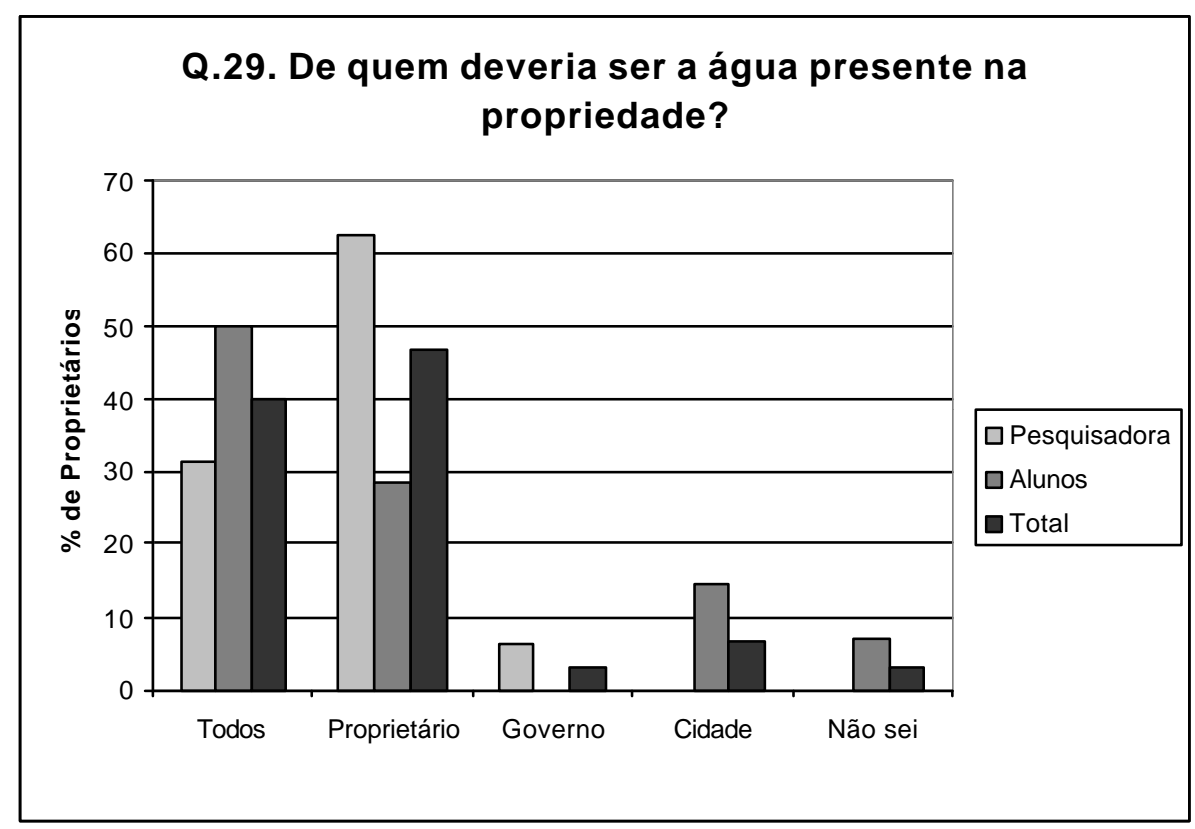

Figura 38 - Respostas da questão 29.

Para a maior parte dos entrevistados, a água deveria pertencer aos proprietários rurais em primeiro lugar. No entanto, não é pequena a porcentagem de pessoas que acreditam que a água é de todos, um bem de uso comum do povo. 


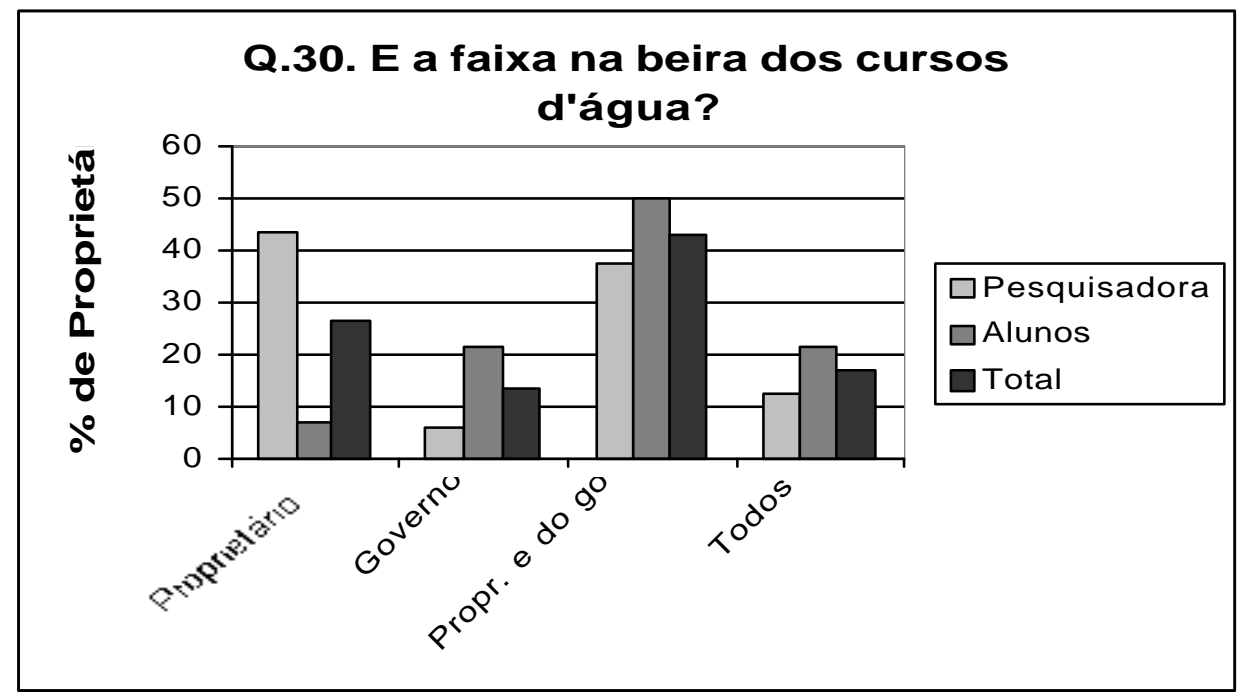

Figura 39 - Respostas da questão 30.

A conservação da mata ciliar, no entanto, deve ser promovida pelos proprietários com a ajuda do governo (incentivos fiscais, mão de obra, mudas, manutenção, projetos, etc., estão entre as reivindicações dos proprietários rurais).

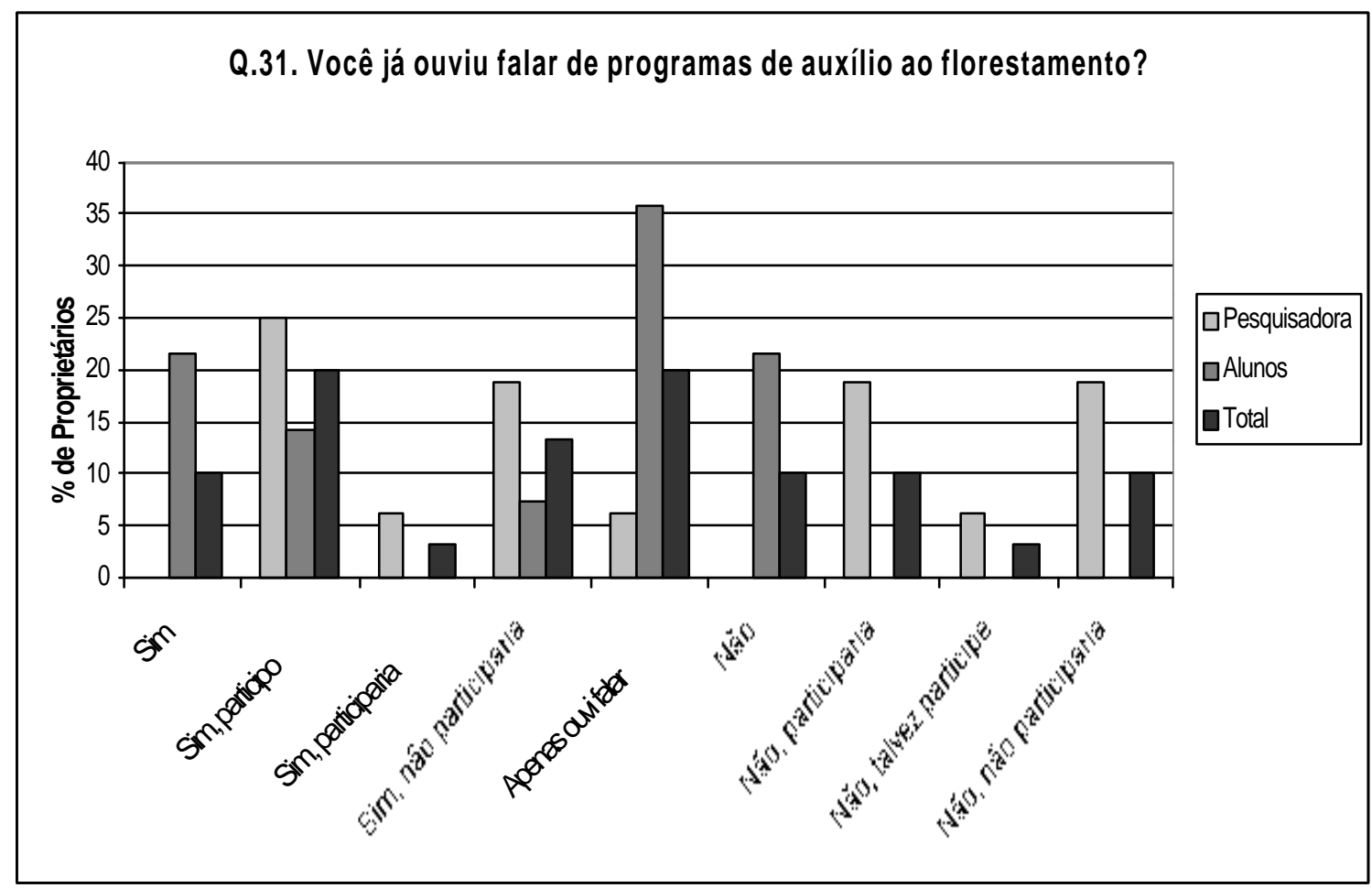

Figura 40 - Respostas da questão 31.

Grande parte dos entrevistados já ouviu falar de programas de auxílio ao reflorestamento. Cerca de $20 \%$ deles afirmam já ter participado de algum destes programas (recebendo mudas, fazendo projetos, recebendo orientações,...). 


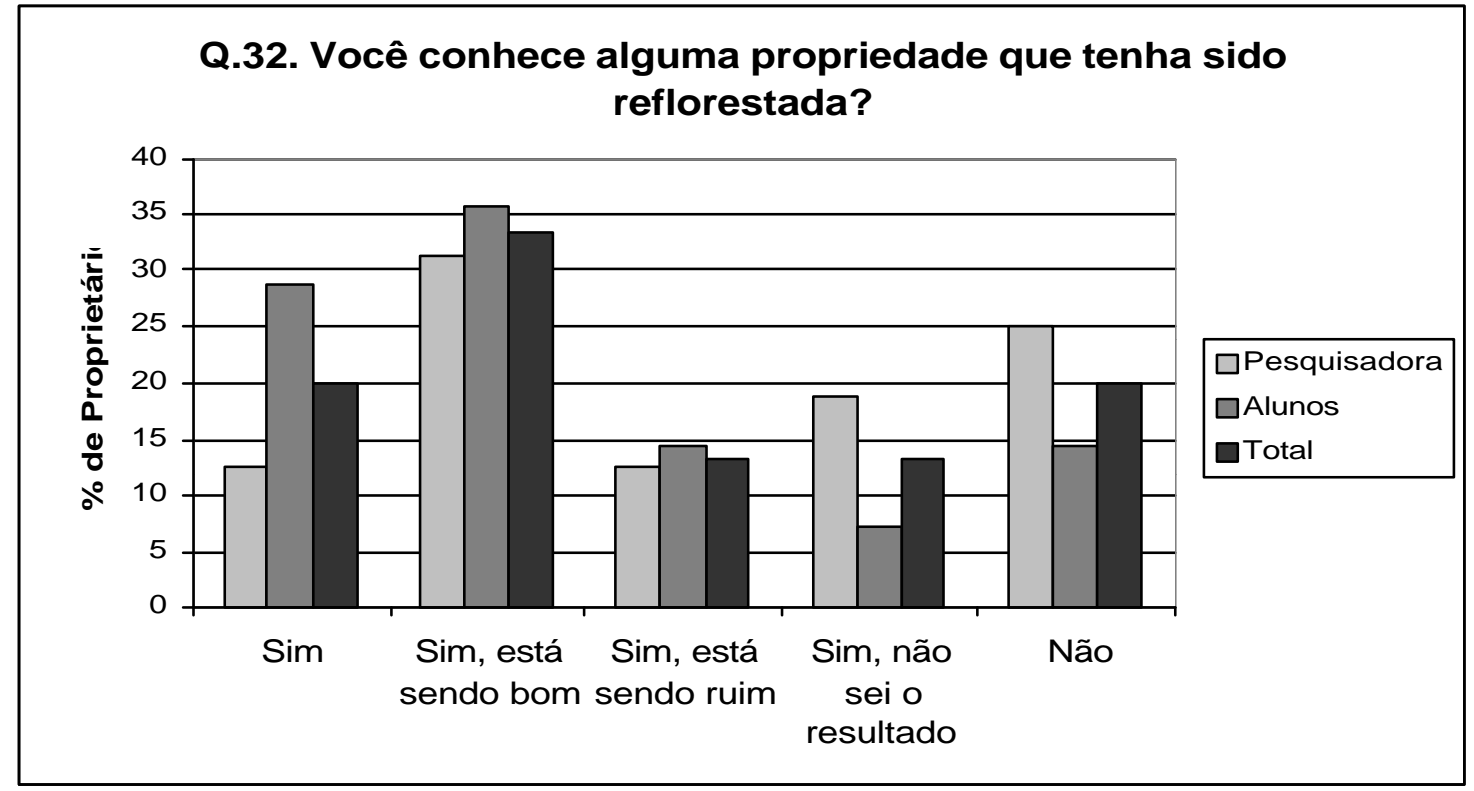

Figura 41 - Respostas da questão 32.

A maioria dos entrevistados que conhecem propriedades reflorestadas, acreditam que o plantio beneficiou os proprietários.

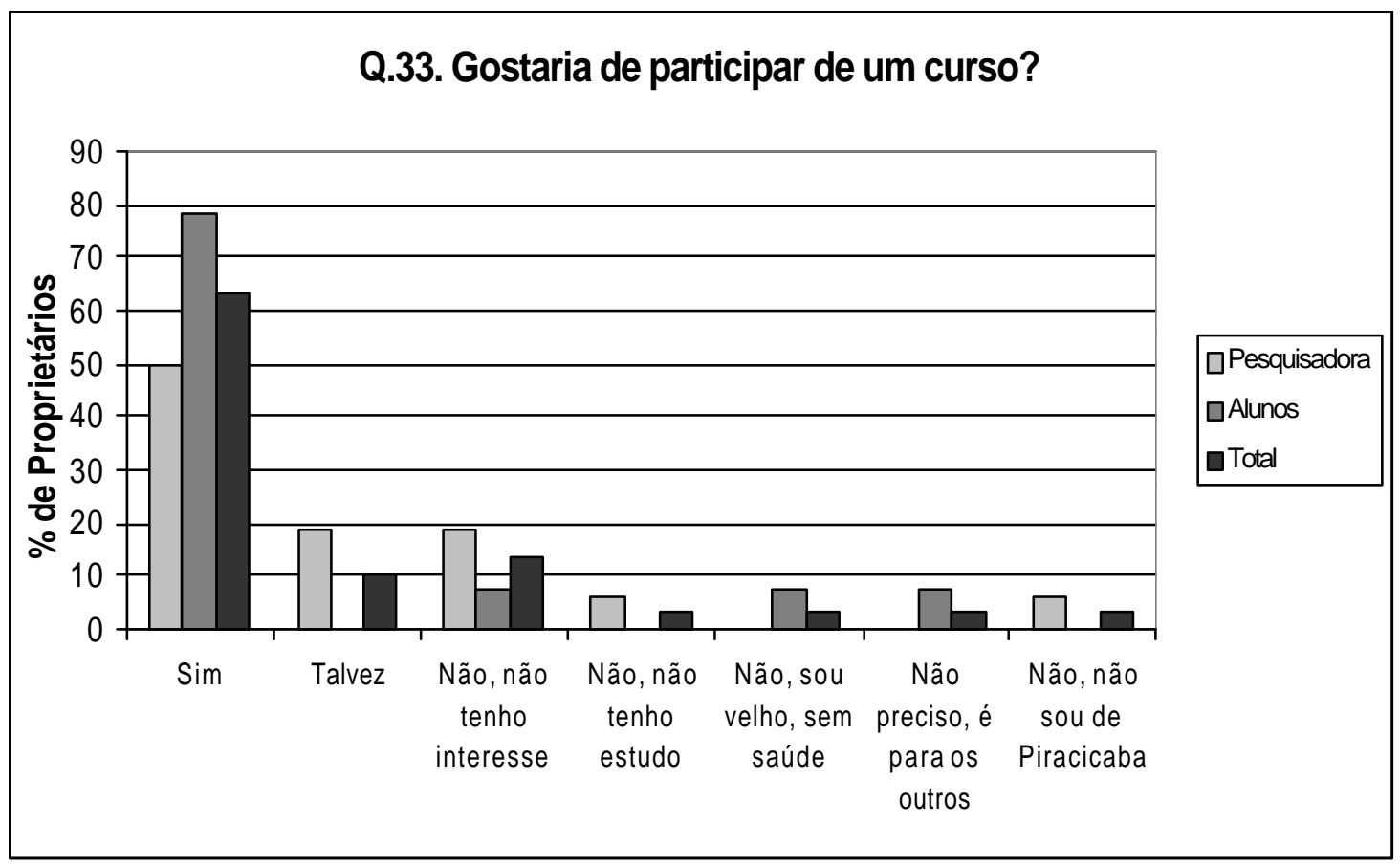

Figura 42 - Respostas da questão 33 (A).

Cerca de $63 \%$ dos proprietários entrevistados, demonstraram interesse em participar de um curso abordando aspectos da Legislação Florestal e da proteção à Natureza. 


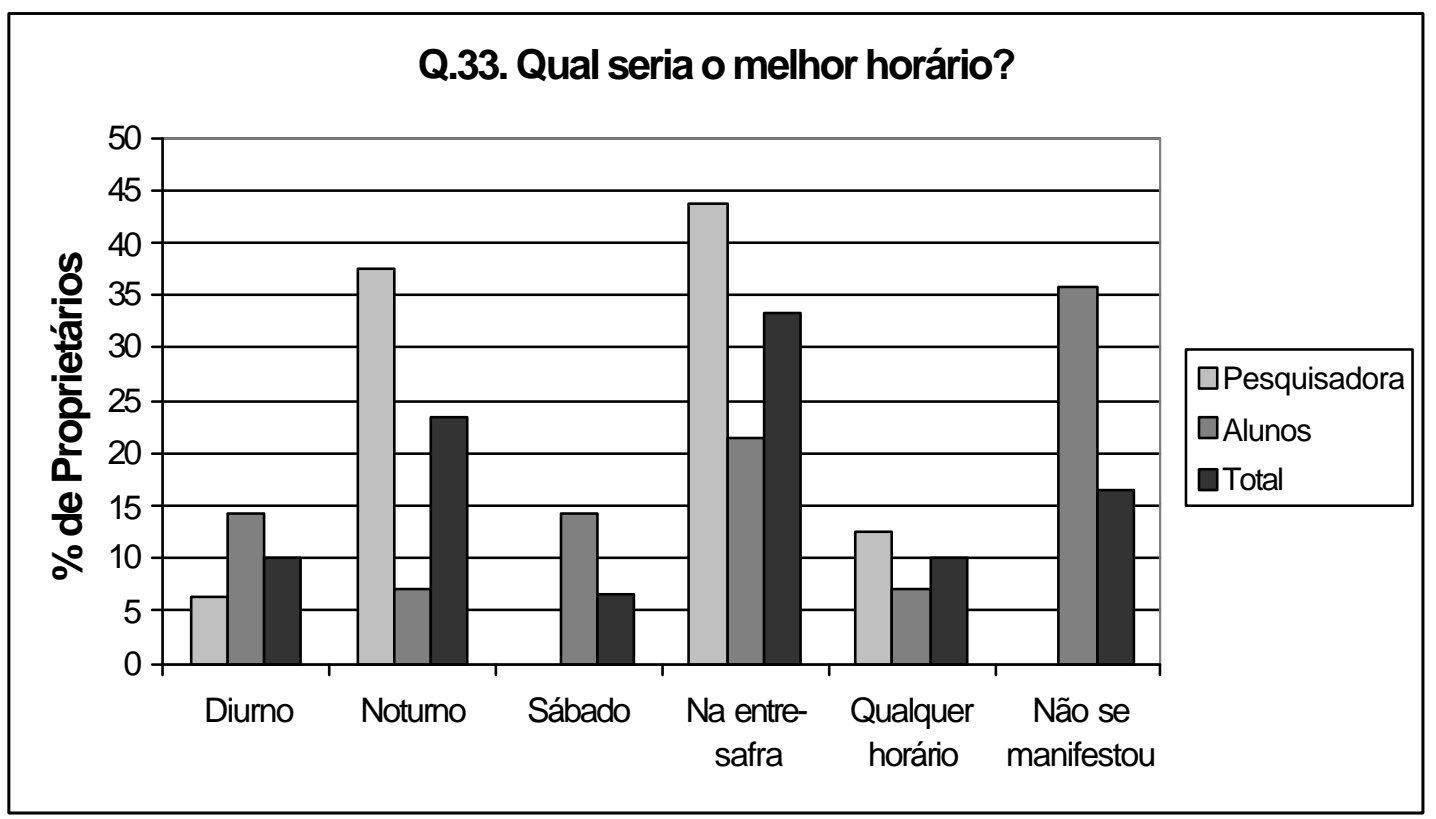

Figura 43 - Respostas da questão 33 (B).

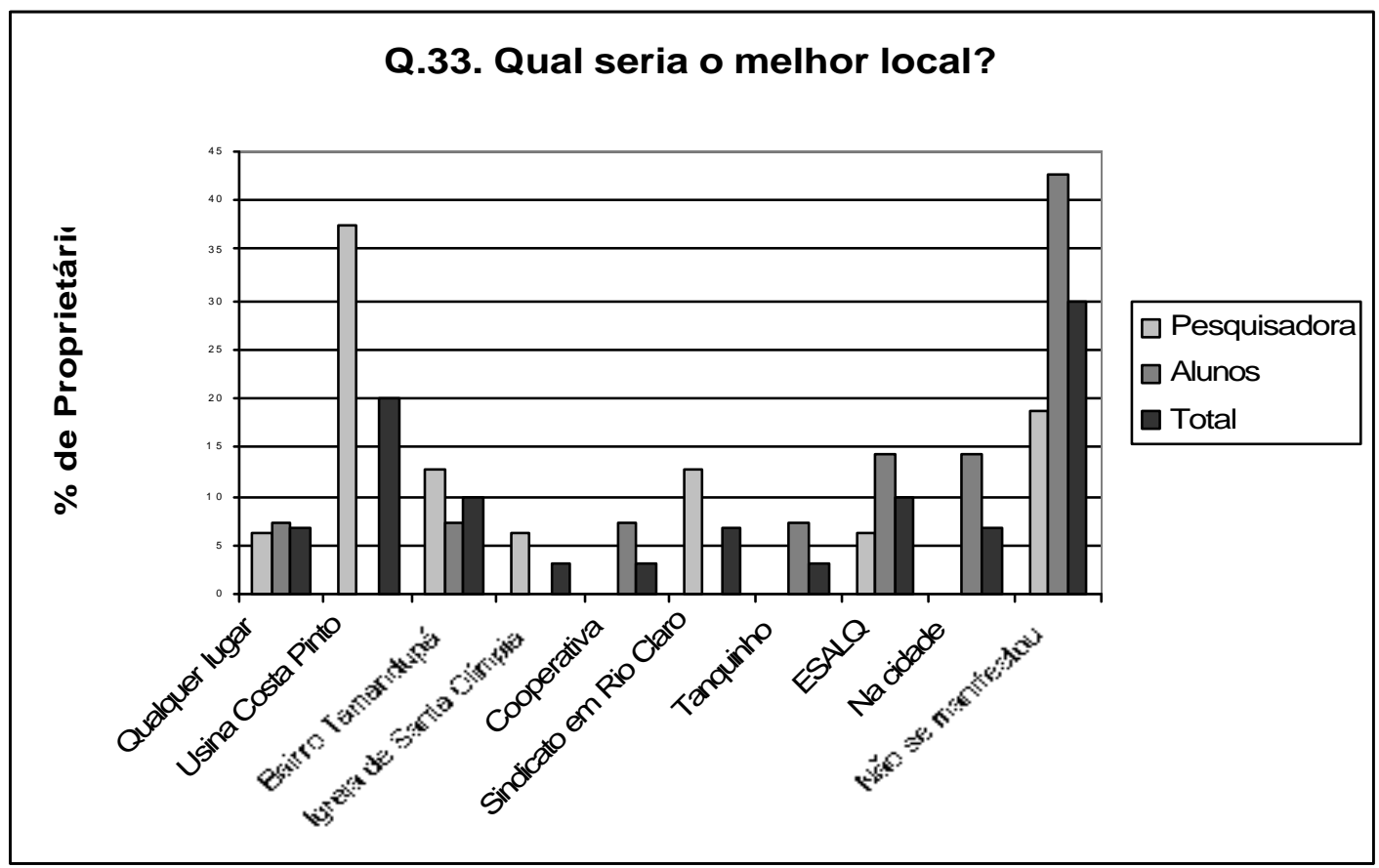

Figura 44 - Respostas da questão 33 (C).

Os entrevistados apontaram como melhor horário e local para a realização do curso, o período noturno, durante a entre-safra de cana-de-açúcar, na Usina Costa Pinto. 


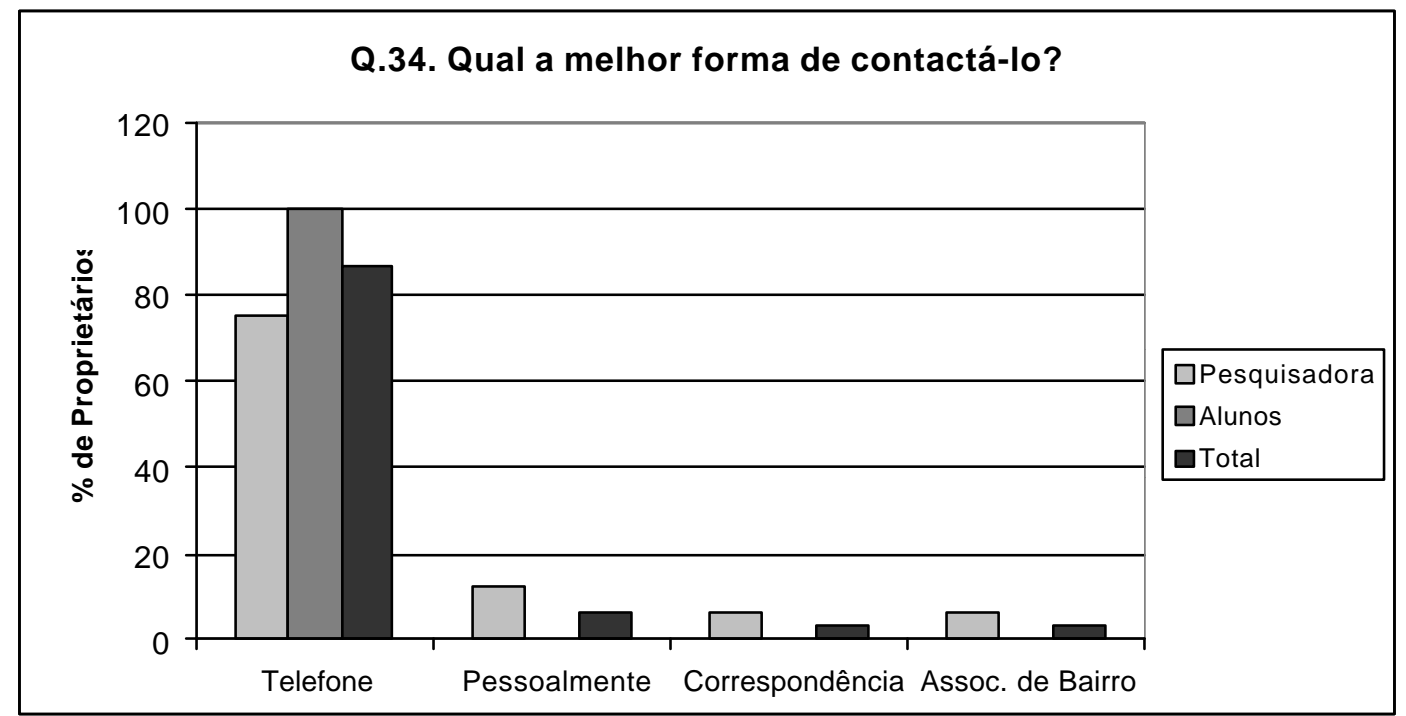

Figura 45 - Respostas da questão 34.

A melhor forma de contatar os entrevistados é através do telefone.

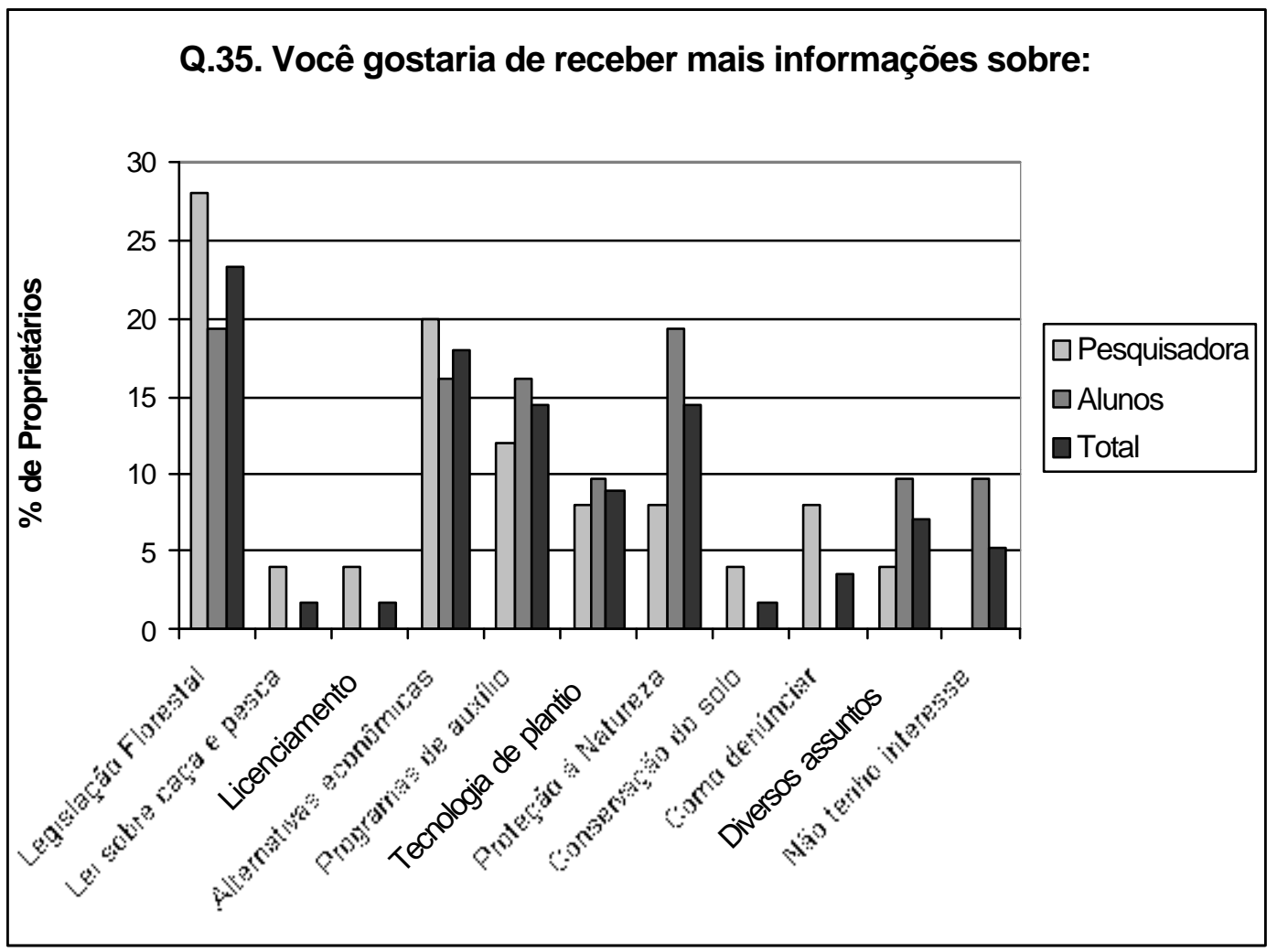

Figura 46 - Respostas da questão 35.

Os assuntos pelos quais os proprietários rurais demonstraram maior interesse são, pela ordem, Legislação Florestal, Alternativas Econômicas Envolvendo Árvores, Programas de Auxílio ao Florestamento e Proteção à Natureza. 
Analisando os gráficos acima, observa-se que em geral não há grande discrepância entre os resultados obtidos através de entrevistas feitas pela pesquisadora, daquelas feitas pelos alunos. A grande vantagem do primeiro procedimento, é a maior aproximação da pesquisadora com os proprietários rurais, o aumento de confiança devido ao maior convívio entre pesquisadora e público alvo e a possibilidade de coleta de informações baseadas nas observações e percepção da responsável pelo estudo.

\subsubsection{Estratificação dos Resultados}

Com o intuito de melhor caracterizar os proprietários rurais de acordo com as respostas obtidas com a aplicação dos questionários, optou-se por agrupar suas respostas de acordo com as indicações de percepção do elemento arbóreo e da legislação florestal.

Obteve-se então os quadros abaixo, que buscam caracterizar pessoas com determinado nível de percepção, de acordo com o tamanho de sua propriedade, seu grau de escolaridade, sua idade e o fato de residir ou não na propriedade rural.

\begin{tabular}{|l|c|c|c|c|c|c|c|c|c|c|}
\hline \multicolumn{2}{|l|}{ Percepção } & \multicolumn{9}{|c|}{ Tamanho da propriedade } \\
\hline ARVORE. & $\mathrm{N}$ & $\%$ & Peq. & $\%$ & Méd. & $\%$ & Grd. & $\%$ & Usina & $\%$ \\
\hline Otima & 0 & 0,0 & 0 & 0 & 0 & 0,0 & 0 & 0,0 & 0 & 0,0 \\
\hline Boa & 5 & 16,7 & 4 & 80 & 1 & 20,0 & 0 & 0,0 & 0 & 0,0 \\
\hline Média & 14 & 46,7 & 9 & 64,3 & 2 & 14,3 & 2 & 14,3 & 0 & 0,0 \\
\hline Regular & 10 & 33,3 & 6 & 60,0 & 2 & 20,0 & 1 & 10,0 & 1 & 10,0 \\
\hline Ruim & 1 & 3,3 & 0 & 0,0 & 1 & 100 & 0 & 0,0 & 0 & 0,0 \\
\hline & & & & & & & & & & \\
\hline LEl. & $\mathrm{N}$ & $\%$ & Peq. & $\%$ & Méd. & $\%$ & Grd. & $\%$ & Usina & $\%$ \\
\hline Ötima & 0 & 0,0 & 0 & 0,0 & 0 & 0,0 & 0 & 0,0 & 0 & 0,0 \\
\hline Boa & 0 & 0,0 & 0 & 0,0 & 0 & 0,0 & 0 & 0,0 & 0 & 0,0 \\
\hline Média & 17 & 56,7 & 9 & 52,9 & 3 & 17,6 & 3 & 17,6 & 1 & 5,9 \\
\hline Regular & 11 & 36,7 & 8 & 72,7 & 3 & 27,3 & 0 & 0,0 & 0 & 0,0 \\
\hline Ruim & 2 & 6,7 & 2 & 100 & 0 & 0,0 & 0 & 0,0 & 0 & 0,0 \\
\hline
\end{tabular}

Quadro 5 - Estratificação dos resultados: Percepção X Tamanho da Propriedade. 


\begin{tabular}{|l|c|c|c|c|c|c|c|c|}
\hline \multicolumn{7}{|l|}{ Tabulação Geral } & \multicolumn{2}{l|}{ Escolaridade } \\
\hline ÁRVORE. & $\mathrm{N}$ & $\%$ & $\begin{array}{c}\text { Fund } \\
.\end{array}$ & $\%$ & Méd. & $\%$ & Sup. & $\%$ \\
\hline Ótima & 0 & 0,0 & 0 & 0,0 & 0 & 0 & 0 & 0 \\
\hline Boa & 5 & 16,7 & 4 & 80,0 & 0 & 0 & 1 & 20 \\
\hline Média & 14 & 46,7 & 6 & 42,9 & 5 & 35,7 & 3 & 21,43 \\
\hline Regular & 10 & 33,3 & 4 & 40,0 & 3 & 30 & 3 & 30 \\
\hline Ruim & 1 & 3,3 & 0 & 0,0 & 0 & 0 & 1 & 100 \\
\hline & & & & & & & & \\
\hline LEl. & $\mathrm{N}$ & $\%$ & Fund & $\%$ & Méd. & $\%$ & Sup. & $\%$ \\
\hline Ótima & 0 & 0,0 & 0 & 0,0 & 0 & 0 & 0 & 0 \\
\hline Boa & 0 & 0,0 & 0 & 0,0 & 0 & 0 & 0 & 0 \\
\hline Média & 17 & 56,7 & 8 & 47,1 & 4 & 23,5 & 5 & 29,41 \\
\hline Regular & 11 & 36,7 & 4 & 36,4 & 4 & 36,4 & 3 & 27,27 \\
\hline Ruim & 2 & 6,7 & 2 & 100 & 0 & 0 & 0 & 0 \\
\hline
\end{tabular}

Quadro 6 - Estratificação dos resultados: Percepção X Grau de Escolaridade.

\begin{tabular}{|l|c|c|c|c|c|c|c|c|c|c|c|c|}
\hline Percepção & \multicolumn{1}{|c|}{ Idade } & \multicolumn{10}{|c|}{ Reside na área } \\
\hline ARVORE. & $\mathrm{N}$ & $\%$ & $30-50$ & $\%$ & $51-70$ & $\%$ & $71-90$ & $\%$ & Sim & $\%$ & Não & $\%$ \\
\hline Ótima & 0 & 0,0 & 0 & 0 & 0 & 0,0 & 0 & 0 & 0 & 0,0 & 0 & 0,0 \\
\hline Boa & 5 & 16,7 & 2 & 40 & 1 & 20,0 & 2 & 40 & 4 & 80,0 & 1 & 20,0 \\
\hline Média & 14 & 46,7 & 4 & 29 & 7 & 50,0 & 3 & 21 & 6 & 42,9 & 8 & 57,1 \\
\hline Regular & 10 & 33,3 & 5 & 50 & 5 & 50,0 & 0 & 0 & 0 & 0,0 & 10 & 100,0 \\
\hline Ruim & 1 & 3,3 & 1 & 100 & 0 & 0,0 & 0 & 0 & 0 & 0,0 & 1 & 100,0 \\
\hline & & & & & & & & & & & & \\
\hline LEl. & $\mathrm{N}$ & $\%$ & $30-50$ & $\%$ & $51-70$ & $\%$ & $71-90$ & $\%$ & Sim & $\%$ & Não & $\%$ \\
\hline Otima & 0 & 0,0 & 0 & 0 & 0 & 0,0 & 0 & 0 & 0 & 0,0 & 0 & 0,0 \\
\hline Boa & 0 & 0,0 & 0 & 0 & 0 & 0,0 & 0 & 0 & 0 & 0,0 & 0 & 0,0 \\
\hline Média & 17 & 56,7 & 5 & 29 & 11 & 64,7 & 1 & 5,9 & 7 & 41,2 & 10 & 58,8 \\
\hline Regular & 11 & 36,7 & 5 & 45 & 3 & 27,3 & 3 & 27 & 2 & 18,2 & 9 & 81,8 \\
\hline Ruim & 2 & 6,7 & 0 & 0 & 1 & 50 & 1 & 50 & 1 & 50,0 & 1 & 50,0 \\
\hline
\end{tabular}

Quadro 7 - Estratificação dos resultados: Percepção X Idade e Residência.

Os procedimentos para a atribuição de conceitos à percepção que os proprietários rurais tem sobre árvore esobre legislação florestal, que permitiram a construção da tabela acima, encontram-se descritos no Item 3.3.1 da Metodologia. 


\subsubsection{Análises da Percepção}

Os gráficos apresentados no item 4.2.1, exibiram separadamente as respostas obtidas pela pesquisadora e pelos alunos que auxiliaram nas entrevistas com o intuito de detectar diferenças entre os dois métodos de aplicação de questionários. No entanto, não houve diferença significativa entre os dois momentos de entrevistas no que diz respeito às respostas tabuladas. Por outro lado, durante a realização das análises sobre a percepção dos proprietários rurais em relação ao elemento arbóreo e à legislação florestal, foi possível diferenciar os dois grupos devido a aplicação do método observacional de coleta de dados, aplicado pela pesquisadora. Deste modo, o grupo dos 16 primeiros entrevistados pôde ser analisado com um pouco mais de profundidade, apresentando graus de percepção mais variados do que o grupo dos 14 proprietários entrevistados pelos alunos, cujas respostas giraram em torno de um grau de percepção mediano.

O processo de caracterização dos entrevistados de acordo com o grau de percepção, foi efetuado a partir da estratificação dos resultados da entrevista. Notou-se uma clara repetição de padrões, facilmente observados nas Tabelas 3, 4 e 5 dos Resultados, o que dificultou um pouco as análises. Algumas considerações no entanto, puderam ser inferidas:

De acordo com os dados coletados sobre a percepção em relação ao elemento arbóreo, nota-se que o número de pessoas com percepção "boa" é pequeno, representando apenas $16 \%$ do total de respostas dos entrevistados. Esta ocorrência pode ser considerada como um dos indicativos do baixo comparecimento dos proprietários às atividades educacionais realizadas durante a pesquisa, isto porque, uma "boa" percepção poderia significar um maior interesse sobre o tema a árvore na propriedade rural. Acrescenta-se que um dos proprietários presentes na primeira atividade realizada, chegou a declarar explicitamente a falta de interesse em discutir sobre o elemento arbóreo por parte dos vizinhos, ao ser questionado sobre os motivos do baixo comparecimento ao evento. É importante ressaltar porém, que estes indivíduos com boa percepção sobre árvores, caracterizam-se por serem pequenos proprietários, com escolaridade baixa (apenas ensino fundamental), com idade variada e que residem em suas propriedades rurais. 
Ainda sobre a percepção com relação à árvore, observa-se que a maior parte dos entrevistados, 46\%, possuem percepção média, sendo que estes podem ser caracterizados como sendo em sua maioria pequenos proprietários, com ensino fundamental, idade entre 51 e 70 anos, e não residentes na propriedade. Aqueles com percepção regular, possuem em geral, as mesmas características. O único indivíduo com percepção ruim, é um médio proprietário, com ensino superior, pouca idade (entre 30 e 50 anos) e que não reside na área. Este último dado nos leva a crer que mesmo aqueles com melhor grau de instrução e condições financeiras mais favoráveis, podem ter uma percepção sobre a importância das árvores, bastante ruim, atribuindo valores pequenos à existência das mesmas.

É interessante observar que a percepção daqueles que residem na propriedade, é em geral, melhor do que a dos proprietários que residem na cidade. Além disto, os pequenos proprietários também se destacaram como sendo aqueles com melhor percepção sobre o elemento arbóreo, o que demonstra uma maior aproximação e valorização da árvore em suas propriedades. Este dado coincide com a afirmação de alguns proprietários que indicam ser melhor a conduta ambiental daqueles que residem na propriedade, do que a daqueles que não residem.

Com relação à legislação, 17 pessoas possuem percepção média, 11 regular e 2 pessoas possuem percepção nuim. Nenhum dos entrevistados apresenta visão boa ou ótima do assunto. Observa-se assim, que a percepção sobre legislação é mais deficiente do que sobre o elemento arbóreo, demonstrando um menor interesse para as questões legais. Este dado coincide com declarações de alguns autores como Aguiar (1994), que afirma ser a legislação, algo desconhecido para grande parte da população brasileira.

Nestes grupos com percepção média, regular e ruim sobre a legislação, observa-se coincidências em características como tamanho da propriedade, grau de escolaridade e residência, sendo que a maior parte das pessoas desses grupos são pequenos proprietários, que só freqüentaram o ensino fundamental, e que não residem na propriedade. Apenas a idade das pessoas destes grupos é que varia, sendo que os indivíduos mais moços possuem uma percepção regular sobre a legislação florestal, e aqueles com mais de 50 anos, possuem percepção variando de média a ruim. 


\subsubsection{Declarações Importantes dos Proprietários Rurais}

Além do agrupamento e da tabulação dos resultados obtidos durante as entrevistas, foram destacadas algumas declarações feitas pelos entrevistados, que somadas a observações feitas em campo, auxiliaram no conhecimento e caracterização desses proprietários, refletindo opiniões (destacadas em negrito) que podem caracterizar o entendimento deste grupo e , muitas vezes, o de setores rurais mais amplos. São elas:

\section{a) É necessário igualdade de condições e de tratamentos entre pequenos, médios e grandes produtores.}

"As leis devem ser cumpridas por todos. Grandes e pequenos. Quem está em cima (cabeceira) e quem está embaixo".

"Os programas de reflorestamento tinham que atingir todos juntos para dar certo. As vezes refloresta um e deixa o outro".

"As leis devem existir para todos, não só para alguns. Os pequenos produtores estão sendo muito prejudicados (punidos com multa) por causas injustas".

"Devido à extração de areia, tenho que ter toda a documentação em ordem. Acho que todos devem seguir o meu exemplo. Florestal interdita outros portos, mas o pessoal volta quando o IBAMA distrai".

"Quem tem dinheiro consegue fazer tudo rápido".

"Há diferenciação de tratamento da polícia florestal para determinados grupos (corrupção). Tem comportamento diferente com certos proprietários. É muito mais fácil punir usina que fica mais exposta".

A necessidade de participar de uma ação integrada, exposta nestas declarações feitas pelos proprietários entrevistados, somadas a observações de 
profissionais que atuam na área, dão indícios de uma possível vinculação da ação à observação de exemplos positivos e da percepção de uma igualdade de tratamento entre os diversos tipos de proprietários (pequeno, médio e grande).

Nota-se ainda, que a motivação para a reivindicação de igualdade de tratamentos é diferente para grandes e pequenos proprietários: Os pequenos querem ver os grandes punidos e precisam ter a certeza de que os fiscais não são comprados; enquanto que, os grandes, querem que os pequenos sejam tão pressionados quanto eles, e que tenha as mesma obrigações legais (para que possam competir igualmente, isto porque, os grandes costumam dizer que precisam encarecer seus produtos pois gastam mais com impostos e com a adequação à lei).

\section{b) Não se deve esquecer que o agricultor precisa viver. A questão econômica deve estar presente.}

"Todo mundo que usa (recursos naturais) está prejudicando (o ambiente). Não dá para parar porque todo mundo tem que viver".

"Com as máquinas ficou mais difícil para as pessoas terem trabalho. E não tem como voltar atrás. A gente carpia agora usa herbicida. Se tivesse que voltar a carpir, não dava conta".

"Deve dar um incentivo em dinheiro para as pessoas plantarem".

"Acho bom que tenha programas de reflorestamento, pois vai ter que fazer mesmo (referindo-se a recuperar áreas degradadas). Mas tem que deduzir esta área dos impostos. E um ano não dá para formar a mata (formiga, enchente, pescador). Como ficam estes custos?".

Com estas declarações, os proprietários rurais refletem uma realidade que não pode ser ignorada: o setor está, em geral, descapitalizado. Não se pode, porém, admitir que esta situação sirva como justificativa para a degradação ou para a não recuperação ambiental. $\mathrm{O}$ que se discute freqüentemente no meio acadêmico, político 
e social, é a criação de uma política de incentivos para a recomposição florestal. Esta deve favorecer os pequenos proprietários e tornar exeqüíveis as determinações legais sem que se tornem beneficiadoras daqueles que até então só degradaram o meio ambiente.

Uma reflexão sobre a atual lógica do mercado, valorizando mais a quantidade do que a qualidade e a forma de obtenção dos produtos, deve ser revista. Um caminho para isto pode ser os chamados "selos verdes".

c) A observação de maus exemplos dados por vizinhos, turistas, usina, cidade, etc. acaba por desmotivar os proprietários rurais a protegerem o meio ambiente.

"Não pesco mais. Fiquei aborrecido porque teve uma época que só tinha peixe morto".

"Perto da cidade não pode plantar muito. O pessoal põe fogo".

"Os rios das cidades estão pior do que os nossos. Por que ninguém faz nada?".

"O rio, depois que veio a usina, não deu mais para usar devido à quantidade de agrotóxico jogado nele".

"Porque eu não posso usar a beira do rio se na cidade tem até rodovia no lugar de árvore?".

Estas declarações reafirmam a importância de ações gerais, amplas. Apontam também, para a necessidade de uma reflexão sobre as responsabilidades individuais, para que os erros do passado (ou até mesmo do presente) não impeçam as pessoas de tomarem atitudes positivas. 


\section{d) Há uma tendência a não assumir para si a responsabilidade sobre os danos ao} meio ambiente. "O outro é sempre o culpado".

"Meu vizinho acabou com tudo de mata. Isso afeta até as águas pra cima. As nascentes sentem".

"Meu vizinho da direita, detesta estas coisas. Diz que morre, mas não planta árvore. Ele diz: 'Nasci aqui, nunca fiz mal a ninguém, por que querem fazer isto na minha propriedade?'”.

"Quem mais precisa não vêm aos cursos".

"Tinha menos mata quando eu comprei a propriedade, do que hoje. Já tava tudo derrubado".

"O povo diz que árvore atrapalha o pasto".

"O meu vizinho não quer nem saber de plantar. Para ele não interessa pois beneficia só os que estão rio abaixo".

"É ruim estar numa bacia que abastece Piracicaba, porque a cidade suja o rio. As pessoas da cidade falam que quem está prejudicando o rio são as pessoas do sítio, mas quem está prejudicando, na verdade, são as pessoas da cidade".

"Acredito que a mata protege o rio. Mas na minha propriedade, a falta de mata não prejudica o rio".

As declarações acima são de duas naturezas: algumas refletem a postura de não observar erros nas próprias propriedades e sim nas dos vizinhos e de achar que apenas os outros precisam receber informações; e outras parecem indicar opiniões pessoais, mas por medo ou desejo de não se comprometer, alguns entrevistados preferiram se referir a outras pessoas (como por exemplo os vizinhos) como possuidoras daqueles pensamentos. 


\section{e) Há diversas motivações para plantar árvores.}

"Se continuar como está, os filhos não vão ver (determinadas árvores), como eu não vejo Pau Brasil".

"A mata é uma boniteza!".

“Já foram plantadas árvores para a recuperação da mata com espécies nativas".

"Plantaria espécies nativas para utilizar a área para o ecoturismo".

"Plantaria mata, pois gosto muito de árvores. Para alimentação, sombra, proteção do solo, etc.".

"Plantaria árvores com o objetivo de preservação das espécies vegetais, dos animais e para melhorar o ambiente".

"Plantaria eucalipto para vender".

"Tenho estima pelas árvores. Jatobá é muito bonita. Tem as que rebate o vento. As para sombra. As de fruta. E também é bom para o ar".

"Sombra e Beleza. É tão gostoso a árvore, o cheiro dela! Árvore tem uma mais bonita que a outra. Como flor. Muitas ainda são frutíferas".

"Árvore na propriedade deixa mais bonito e serve para os pássaros criarem seus ninhos".

"Para conservar o solo e a natureza. Dá outro ar, outra vida. Sem calor".

"Para conservar os rios, evitar erosão, evita levar sujeira para dentro do rio". 
"A Mata influi em tudo. Serve mais para criar passarinhos, bichos. O que será do mundo sem uma borboleta? Nada. Muita planta e passarinho é bom porque controla muita coisa. Formiga, se Deus fez, alguma utilidade tem. E se acabar mata, acaba tudo isto. Café e laranja até que não, mas lavoura mecânica acaba com tudo".

"A mata segura a umidade e regula as chuvas, além disso evita voçorocas na beira do rio e fornece matéria orgânica para o solo".

"A floresta equilibra o meio ambiente, preserva a fauna e o ecossistema. O homem não sabe disso!".

"As matas devem ser protegidas porque são fontes de recursos".

"Serve para a proteção de rios, abrigo de animais e se todos que tivessem uma pequena florestas preservassem, não iria faltar árvores mesmo para uso pessoal".

"Tendo mato no terreno de cima, o mato segura toda a terra e não desbarranca".

"Nossa vida depende da existência das matas".

"Conheço uma propriedade que depois que foi reflorestada, aumentou água, fauna, a propriedade ficou mais bonita, houve controle de erosão".

"As árvores na beira do rio protege os peixes. Eu acho bonito e serve pros peixes".

"A mata ciliar protege o rio, mas tem que deixar do tamanho adequado para impedir a poluição".

"Mata é importante por causa dos animais. Porque aonde tem mais bicho tem mais controle de pragas. Em 100 ha com árvores há menos pragas que em 100 ha sem árvores". 
$\mathrm{Na}$ fala dos entrevistados, nota-se que inúmeros benefícios trazidos pelas árvores, florestas e matas, são percebidos entre os proprietários rurais. Alguns demonstram ainda, grande afetividade por estes elementos da Natureza.

Estas declarações possuem grande potencial para serem utilizadas em intervenções educacionais, pois trazem conhecimentos semelhantes aos encontrados em livros e revistas científicas, porém, estão na linguagem utilizada pelos próprios proprietários rurais.

\section{f) Há também motivações para não plantar árvores.}

"Eucalipto demora muito tempo para dar dinheiro".

"Deixei algumas nativas crescerem. Agora tem muita mata. A terra ficou pouca".

"Foram plantadas 1800 mudas na beira do Corumbataí, mas quando o rio encheu, morreu metade".

"A prefeitura plantou por duas vezes, mas por falta de cuidado as árvores não foram para frente".

"Não plantaria árvores na minha propriedade pois tem que haver muita responsabilidade, que o capinzal da usina fica próximo e apresenta alto risco de fogo".

"O descaso do Florestal faz com que eu não plante árvores. Todos os marginais põem fogo e a polícia não faz nada".

"Onde tem cana só atrapalha".

"Não planto mais árvores por causa do gado que come ou pisa na muda. O custo do plantio fica muito alto se eu quiser cercar a área para proteger dos animais". 
"Não plantaria árvores na minha propriedade pois poderia faltar incentivo e tudo acabar em nada".

As declarações sobre motivos que levariam os proprietários rurais a não plantar árvores em suas propriedades, devem ser levadas em consideração principalmente durante a elaboração de políticas de fomento ao reflorestamento. $O$ debate, 0 esclarecimento de dúvidas e a organização política dos setores interessados, podem também trazer grandes contribuições para a solução dos problemas levantados.

g) Algumas declarações demonstram preconceitos do proprietário para com as árvores (herança da revolução verde?) e para com determinados movimentos sociais, além de trazer alguns conceitos equivocados.

“Quando comprei, a terra já tava limpa”. (Referindo-se à ausência de mata).

"Os sem terra estão destruindo tudo e a polícia não faz nada".

"Eucalipto puxa água e seca a vertente”.

"Se eu plantar, vou estar perdendo área e dinheiro".

"O Jatobá não desenvolve por causa do Eucalipto".

"Acho que no perímetro urbano a APP é de 10 metros".

"Não sou obrigado a ler jornal ou Diário Oficial".

"Eucalipto seca a água da nascente e as outras árvores não”.

"Deve-se proteger as nativas porque equilibram o meio ambiente e derrubar as de pequeno porte, de campo e cerrado, porque a derrubada não prejudica o meio ambiente". 
"A água dentro da propriedade é da família. E de algum vizinho que necessita. Os outros de fora não resolvem nada".

"A água é do proprietário porque é ele que abre o poço. A água é deixada por Deus para nós".

Estas declarações reafirmam a necessidade de promoção de debate sobre legislação, movimentos sociais, silvicultura, dentre outros. Conceitos como "terra boa é terra limpa (sem árvores)" devem ser repensados.

h) Observa-se, algumas vezes, incoerência entre o que é declarado pelos proprietários rurais e o que é observado em campo na região.

"Existe uma larga faixa (acima das medidas mínimas) ao longo do rio e várias árvores na propriedade".

"Nós não cortamos árvores. São os vândalos que vem da cidade".

"Toda a erosão está controlada".

"Deve proteger os animais. Mas gato atrapalha (eu mato) e capivara não é bom. Tem que soltar rojão para espantar pomba do milho".

Estes são apenas alguns dos exemplos de diferenças entre o que é declarado e o que é observado. Muitos dizem que não cortam árvores, que tem a faixa de mata ciliar bem conservada e acima da exigência legal, que protegem os animais, porém, durante as visitas de campo, foi possível averiguar que a maior parte das áreas de preservação permanente da região se encontra em situação irregular, que muitos animais são mortos pelos próprios proprietários rurais, etc. 


\section{i) Alguns proprietários percebem mudanças negativas no ambiente, mas não associam à ação humana, enquanto outros percebem nitidamente a influência antrópica diante dos problemas ambientais.}

"A terra está ruim porque a chuva vem como tromba d'água. Antes chovia mais fraco e por vários dias seguidos. Agora vem tudo de uma vez".

"Acho que chove diferente. Vem como temporal. Mudou. Pode ser que em alguns anos volte. A culpa é dos astros, das estrelas. O cruzeiro do sul virou de uma noite para a outra. Pode ter alguma ligação!".

"Só piorou o clima. O tempo não é mais como antigamente. A chuva não vem na hora certa. Deve-se ao desmatamento".

"Cada ano tá diminuindo a chuva. O pessoal fala que é desmatamento, mas não sei não".

"As terras estão cansadas, são 70 anos plantando".

"Solo fica fraco como pessoa. Falta de meio ambiente, árvore. Onde tem mata é fresco, mas lá, foi surgindo cidades".

"Quando a usina passa veneno para amadurecê a cana, mata mamão".

"Derrubaram muita mata e então diminuiu as águas. Tem lugar que derrubaram até vertente. Plantio de cana estraga a barroca e entope tudo. Estora curva de nível. Eu pego o risco da água e faço curva de nível. Depois que começaram a passar máquina, afundou o caminho e não tem mais jeito".

"Está mais quente. Porque faltam árvores". 
"Tem menos peixe do que havia alguns anos no rio e é mais difícil ver alguns bichos na mata do que antes (capivara, por exemplo). É porque tem muita gente caçando e pescando em épocas inadequadas".

"O grande problema da região é a utilização de agrotóxicos. Seca a terra. Todos usam. Ainda que o "Roud Up" não faz isto (não estraga muito a terra)".

É interessante observar que muitos proprietários associam a ação humana aos problemas ambientais que vêm enfrentando. Eles mesmos declaram que o desmatamento é prejudicial e pode ter ligação com as mudanças climáticas. Este pode ser um bom elemento motivador para o plantio de árvores em propriedades rurais.

\section{j) Alguns acreditam ser bom ter sua propriedade na Bacia Hidrográfica que abastece Piracicaba de água. Outros acreditam que só há desvantagens.}

"Estou contente porque a água (do Corumbataí) limpou muito”.

"É bom porque propriedade sem rio perto não tem valor. É um dom da Natureza. Coisa mais linda!".

"Bom, ótimo. Fica mais respeitado".

"É ruim. Tenho porto de areia e toda hora vem fiscalização. A Sedeplama e a polícia florestal não dão sossego. Ficam em cima. Fiz 5 lagoas, agora não faço mais”.

"Não é bom. Puxam a água e o rio diminui o nível".

"Não ajuda do jeito que tá, estão exigindo muito. A água é boa mas a faixa é demais. Deveria começar com 5 metros, depois ir aumentando". 
"Mais para ruim do que para bom. Dá medo de causar um dano e a lei vir para cima e não ter como se defender. Se alguém tocar fogo próximo a gente é que paga. Antes davam valor a água no sítio. Hoje ninguém mais quer".

O medo dos proprietários em relação às leis, demonstra a necessidade de maior conhecimento das mesmas para que haja maior segurança e participação dos mesmos nos debates que visam a alteração destas leis (como por exemplo, as audiências públicas sobre as modificações no Código Florestal).

\section{I) Grande parte dos proprietários desconhece as leis.}

"Sei que existe mas não sei o conteúdo".

"Já ouvi falar".

Este dado já era esperado, pois repete-se em quase todos os setores da sociedade. Não se deve esquecer porém, que não é possível se esquivar do cumprimento da lei através desta declaração, assim, o melhor é conhecer as leis existentes e, se possível, participar do processo de elaboração das mesmas. Por isto as medidas educacionais são então, indispensáveis.

m) A maioria dos proprietários declara que as leis deveriam ter mais flexibilidade, bom senso.

"A lei a gente respeita. Mas tem que ter flexibilidade".

"Deve ter bom senso. Hoje não pode cortar um capim sem autorização! Como a pessoa vai saber?!". 
"Deveria poder cortar as árvores sem qualidade no meio da lavoura para deixar mais livre. Se tiver árvore no meio, fica ruim queimar a cana. Deveria proteger as árvores boas (nativa, com frutas)".

"Deve proteger em volta das nascentes e cursos d'águas, pois o vento seca as nascentes e as árvores protegem as nascentes do vento. Mas deveria pode ser explorada de acordo com a necessidade do ser humano. Porque o homem vem em primeiro lugar".

"As pessoas que causam danos ao meio ambiente, devem ser punidas com certeza. Menos em caso de acidente".

"Deve ter uma lei para proteger as matas. Mas, se precisa de madeira, seria bom poder cortar na beira do rio. No rio deveria dar árvore em galeiro".

"Conheço alguma coisa da lei. Acho 30 metros muito para um córrego de 2 metros. 10 ou 15 metros tava bom. Até 20. Se não, acaba a lavoura, faz sombra. E acho que deveria punir todos igualmente. A polícia deveria tratar todos igual. Tem muita lei que deixa com medo. Prejudica e desanima quem já nem tem muito ganho".

"Tem coisa que é boa e coisa que é ruim (na lei). Brejo, não pode fazer valeta, melhoramento. É difícil conseguir autorização para fazer represa".

"Deve ter leis mas tem que existir o bom senso. Hoje não tem conversa. Primeiro faz multa, não fala como deveria ser. Não se pode cortar um fio de capim sem autorização. Como a pessoa vai saber? A promotora fala um monte. Xinga. Já tenho uma condenação. Não posso sair por dois anos".

"Multas muito altas são impossíveis de se pagar e colocam o agricultor na marginalidade".

"Seria bom produzir nas margens, mas lei é lei”. 
"Deveria ter lei que protege a Natureza, a não ser se for a maioria mata e precisar plantar, daí poderia tirar um pouco".

"Deve haver bom senso".

"Antes, só os rios grandes eram da marinha. O proprietário deveria ter um pouco de autoridade para correguinho pequenininho. Quem quer a água deve cuidar. Se unir".

Os proprietários levantam questões como flexibilidade da lei e bom senso no momento de sua aplicação. É importante que estes assuntos sejam discutidos para que esclarecimentos sejam feitos e o motivo da criação destas leis sejam conhecidos. Com isto poderá haver menor revolta dos proprietários com relação a instrumentos de defesa dos interesses da coletividade, inclusive os deles próprios.

\section{n) Alguns acham que a lei deveria ser mais severa.}

"A lei deveria ser severa. Se não der pena dura para o sujeito, eles vão continuando. Multa não pagam".

"A lei tem que ser mais severa para punir esta turma de 16 anos. Eles acostumam a não trabalhar. Tinha que começar a trabalhar com 8 anos. Se não eles não tem o que fazer e vem atrapalhar a gente no campo".

"Quem põe fogo na mata merece cadeia perpétua! Quem põe fogo em cana fora do tempo também deveria pegar cadeia".

"Teria que ter uma lei severa para punir quem põe fogo ou corta mata e fazer pagar. Hoje, fica por isto mesmo. Quem tem dinheiro manda. Deveriam ser presos e multados".

"O governo deveria agir com mais rigor". 
"Deveria ter penas maiores para quem polui o ambiente".

Alguns proprietários, em especial aqueles que conhecem e cumprem as leis, concordam com o seu conteúdo e acreditam que leis mais severas poderiam proteger melhor o meio ambiente.

\section{o) Alguns descumprem a lei por opção.}

"Não averbo a Reserva Legal Florestal, porque gosto de ter liberdade. Quero preservar por vontade, não porque sou obrigado. E mesmo que seja descontado o imposto da área, é tão pouco que não vale a pena".

"Acho 30 metros na beira do rio, muito exagerado. Deixo só uns 10 que já tá bom".

Alguns proprietários estão tão convictos da inadequação das leis, que as descumprem por opção. A falta de uma fiscalização mais rigorosa, também contribui par este fato (atualmente, as autuações são feitas principalmente através de denúncias, e não por via de visitas de controle aos estabelecimentos rurais).

\section{p) Muitos afirmam que deveria haver orientação antes da punição e que a fiscalização deveria ser mais eficaz e coerente.}

“Deveria divulgar mais a lei. Não dá para punir se o cara não conhece”.

"Tem que estar sempre conscientizando".

"A polícia florestal só vem para punir, não orienta!".

"A polícia florestal está prejudicando o agricultor. Não deixa mais trabalhar". 
"Antes da punição deveria ter orientação. Principalmente para quem utiliza queima onde é proibido. Estamos cortando crua próximo ao perímetro urbano, estrada ou reserva".

"As pessoas que põe fogo na mata não devem ser punidas, mas orientadas/instruídas. A fiscalização governamental é necessária”.

"Não faltam leis, a lei está certa, mas deve ter mais fiscalização e orientação. A fiscalização não deve ser radical (bruta/impositora). Deve haver mais orientação pois a lei não é clara".

"Acho que seria muito importante recebermos orientações antes de sermos punidos com multa".

"A polícia florestal atualmente só vem punir. Não orienta".

"Fiscalização honesta e principalmente esclarecer antes de multar"

"Deve haver maior preparo das pessoas que fiscalizam, conscientizar os cidadãos".

"Sou a favor de conscientização nas escolas".

"As leis são boas, mas as pessoas não conhecem as leis e não há divulgação e nem fiscalização".

"Estão fazendo revisão das leis. Queria saber o porquê de 100, 50, 30 m em torno do rio. E sobre o tamanho da reserva florestal, mas ninguém esclarece".

"A imprensa deveria divulgar mais a lei. Não dá para punir se o cara não conhece".

A necessidade de orientação e esclarecimentos com relação às leis demonstrada pelos proprietários rurais, dão subsídios para afirmar que uma 
intervenção educacional abordando este tema, torna-se cada vez mais importante para a promoção da proteção ao meio ambiente.

\section{q) O proprietário está desanimado, desmotivado, descrente, desarticulado.}

"Não tenho sonho na minha idade".

"Apenas mantenho a propriedade para ter convênio médico com o hospital dos plantadores de cana".

"Ta difícil. Não tenho nenhum sonho. Ninguém mora mais aqui. Estamos muito sozinhos".

"Não tenho sonhos, provavelmente a minha propriedade será vendida".

"Embora a cana não esteja mais compensando, acho que vou continuar plantando ela mesmo".

Os proprietários refletem aqui, as conseqüências de anos sem receber a devida atenção do poder público brasileiro. A falta de investimentos, tecnologias ou alternativas diferenciadas e mais viáveis economicamente para a vida no campo, faz com que os poucos que não migraram para a cidade, muitas vezes vejam neste ato drástico, a solução para seus problemas pois sentem-se abandonados.

\section{r) O interesse em participar de intervenções educacionais não é incondicional.}

"É difícil pois não tenho tempo e saúde. O ideal é vir alguém ensinar aqui".

"Se todos forem a gente vê".

"Não porque não tive estudo. Mas gostaria de ler sobre assuntos de interesse". 
"É melhor na entresafra e à noite".

"Melhor que seja na Usina".

"Não posso ir. Fale com meu funcionário".

"Deve ser fora da época de plantio e colheita".

Estas declarações serviram para dar indícios de como conduzir uma intervenção educacional de modo a envolver um maior número de pessoas.

\subsection{Resultados de outras fontes de informação}

O questionário aplicado junto a profissionais que atuam na área rural/ambiental na região Piracicaba (encontrado no item 3.4.1 da Metodologia), possibilitou uma visualização da grande diversidade de opiniões entre estas pessoas.

Questionado sobre qual seria sua visão pessoal sobre a possibilidade de adesão de proprietários rurais para o plantio de árvores em suas propriedades, o Secretário da Agricultura do Município de Piracicaba declara que, "de forma geral, o proprietário rural tem uma visão muito clara da importância das árvores. Mas é fundamental que ele seja incentivado a agir nesta direção"; a engenheira agrônoma da Casa da Agricultura afirma ser "difícil a adesão. Apenas uma minoria já está conscientizado"; a engenheira florestal que possui projeto de Educação Ambiental em escolas rurais da região, acredita que para tratar estas questões com proprietários rurais, deve-se primeiramente diferenciar as espécies de árvores a serem introduzidas. "Pinus e Eucaliptos dificilmente eles plantam pois tem medo de cair a árvore, de um raio queimar, etc. Gostam mais de ornamentais (tipo Ipê e Flamboiam). Eles têm medo de árvores que chamam abelhas. A substituição da cultura da cana por árvores, também é muito difícil de conseguir, mas plantar algumas no pasto para fazer sombra para o gado, é mais fácil"; a técnica do setor de reflorestamento do Consórcio Intermunicipal de Bacias Hidrográfica, afirma que "sendo feito contato pela casa da agricultura, fica mais fácil. Daí, tem bastante procura mais o Consórcio não tem 
condições de atender a todos os cadastrados. A saída agora tem sido incentivar os proprietários a estarem plantando por conta própria. O Consórcio dá a muda e o proprietário planta"; o presidente do Sindicato e Cooperativa dos Plantadores de Cana, acredita que "o plantio da árvore é a coisa mais fácil, o difícil é a condução dela. Deveria ser dada assistência por pelo menos dois anos, exigir de alguém, responsabilizar. Se não, não há interesse"; a consultora do Instituto de Pesquisas e Estudos Florestais - IPEF, declara que "os produtores estão convencidos da importância das matas ciliares. O que atrapalha um pouco é a proibição do uso. Se houvesse parcerias, ia facilitar bastante"; o professor da disciplina "Política, Legislação e Administração Florestal" da ESALQ/USP, acredita que a adesão é possível; o analista de projetos ambientais do DEPRN, afirma que "não é fácil a tarefa de fazer com que os proprietários de terra plantem árvores com a intuito de recuperação de áreas de preservação permanente e servir de alimento para a fauna. $O$ objetivo principal deles é trabalhar a terra para produzir alimentos. E muitas das vezes as melhores terras agricultáveis estão nas baixadas acompanhando os cursos d'águas, áreas estas consideradas de preservação permanente conforme lei federal no 4771/65 alterada pela 7.803/89 e medida provisória. Portanto, o plantio de árvores visando a recuperação das faixas de preservação permanente e áreas degradas por erosão geralmente é realizado em situações que exigem um compromisso maior do agricultor, como é o caso de processos administrativos. Mesmo assim, após o Termo de compromisso cumprido a tendência é o abandono destas áreas e a degradação por fogo, formigas saúva e competição por espécies invasoras".

Opinando sobre a melhor forma de abordagem para estabelecer o diálogo junto aos proprietários rurais, o Secretário da Agricultura destaca a importância da "educação, políticas de fomento e demonstrações da realidade atual comparada com a realidade no passado"; a engenheira agrônoma da Casa da Agricultura afirma ser preciso "muita insistência de várias formas, com várias abordagens. Por exemplo, deve ser aproveitado o momento em que surge um problema ambiental em uma propriedade, para mostrar os motivos do problema e dizer que é conseqüência da falta de cuidado. Mas mudar a cabeça de quem age daquela forma a 50 anos, é muito difícil. E os proprietários não participam de nada!"; a engenheira florestal que possui projeto de Educação Ambiental em escolas rurais da região, acredita que deve ser feito contato com a Secretaria do Meio Ambiente, com a Casa da Agricultura, com 
Centros Comunitários, com a Pastoral e com Centros de Saúde. "Abordar temas como saúde e educação, atrai mais do que meio ambiente. Portanto, deve-se começar com eles. E acho melhor ir direto no proprietário porque mulheres e crianças não vão interferir na hora de passar informação para os proprietários."; a técnica do Consórcio afirma que "deve-se trabalhar o sentimento de nostalgia, fazer o agricultor falar de como era a área quando ele era criança. Procurar a Casa da Agricultura, a Associação e a Cooperativa, também são boas opções para uma primeira abordagem, pois é com estas instituições que os agricultores tem mais contato" ; o presidente do Sindicato e Cooperativa dos Plantadores de Cana, aconselha fazer uma convocação dos proprietários rurais através da Associação e do Sindicato, e dar esclarecimentos. Ele acredita também, na importância do trabalho com crianças em escolas rurais: "Se a criança aceitar a idéia, ela cobra dos pais!"; a consultora do IPEF, afirma que através do Sindicato Rural, é possível uma ação centralizada, que busque a gestão integrada de floresta e água; o professor da ESALQ/USP, acredita que trabalhos junto a homens, mulheres e crianças, são igualmente importantes, e que devem ser realizados "através de processos diversificados que guardem coerência entre si e façam parte de um programa maior"; e o analista do DEPRN, afirma que o trabalho deve ser feito com proprietários rurais, dividindo-os em três classes: pequeno, médio e grande proprietário".

Os entrevistados foram também convidados a apontar pontos motivadores, que pudessem despertar o interesse dos proprietários rurais para a implementação de árvores em suas propriedades. A sugestão do Secretário da Agricultura baseia-se no envolvimento de uma instituição ou técnico que seja de confiança para os produtores, e que esta pessoa promova a extensão rural para que, no momento apropriado, seja elaborada uma proposta de ação in loco; a engenheira agrônoma da Casa da Agricultura acredita que o caminho seja tratar assuntos atuais, como "o fantasma da falta de água e a cobrança pelo uso da mesma"; a engenheira florestal que possui projeto de Educação Ambiental em escolas rurais da região, afirma que a promoção da Educação Ambiental em escolas é importante e que, para os aos proprietários rurais, é preciso mostrar números que demonstrem o quanto se ganha preservando uma boa água, um ambiente saudável para o gado, etc.; a técnica do Consórcio declara que deve ser apresentados exemplos de pessoas que se deram bem reflorestando, de preferência vizinhos, e ampliar o diálogo com uma linguagem 
adequada (se possível, envolvendo engenheiros da Casa da Agricultura); o presidente do Sindicato e Cooperativa dos Plantadores de Cana, aconselha tratar problemas como a erosão e falar da importância da preservação da Natureza, do solo e da água, que são fundamentais para os agricultores; a consultora do IPEF, afirma que devem ser promovidas parcerias: "incentivos financeiros e possibilidade de manejo bastante leve na Área de Preservação Permanente, pois atualmente são muitas imposições que acabam por promover o benefício de todos (coletividade), com ônus para um (o proprietário rural)"; o professor da ESALQ/USP, declara que "são diversos os pontos motivadores para diferentes pessoas e mesmo para uma mesma pessoa. $O$ fundamental é o diálogo."; e o analista do DEPRN, diferenciando as classes de pequenos e grandes proprietários rurais, afirma que "o pequeno proprietário rural já vive em dificuldade na terra e a forma adequada de incentivá-los a plantar árvores seria através de um retorno direto à sua propriedade, através de implantação de projetos com verbas de instituições internacionais ou nacionais. As associações de bairros seriam o contato ideal para apresentação de tal projeto. O projeto deveria associar agricultura com preservação do meio ambiente. Já para o grande produtor e principalmente aquele voltado às grandes culturas como cana-de-açúcar, soja, café etc. o grande motivador para o plantio de árvores seria o ISO 14.000 casado com uma imposição dos órgãos licenciadores e dos aplicadores da lei (MP e Poder Judiciário).

Finalmente, respondendo ao questionamento sobre o fato da legislação estimular ou não o plantio de árvores e qual seria a sugestão dos entrevistados para melhorar a redação e o conteúdo das leis florestais, o Secretário da Agricultura afirma que o plantio de árvores independe da existência de leis "A lei serve para disciplinar e detalhar a execução. Para os proprietários rurais, falar de lei pode gerar uma reação contrária pois eles ficam apreensivos e pensam logo em proibição e prejuízo. A questão depende mais da educação, convencimento e políticas de fomento"; a engenheira agrônoma da Casa da Agricultura também acredita que a lei não estimula o plantio de árvores: "pelo contrário, as pessoas não querem saber de lei. Só quando são penalizados. Quando isto acontece, eles reclamam que ninguém avisou nada". E acrescenta: "O problema é que a lei é aplicada da forma que está no papel. Ao pé da letra. Isto às vezes atrapalha. Deve haver bom senso, mas os legisladores não saem do escritório! Ficam discutindo vírgula e não a realidade.", a engenheira florestal que possui projeto de Educação Ambiental em escolas rurais 
da região, diz que na verdade a lei não estimula, impõe. Para ela, "deve ser feito um trabalho educacional para mostrar a importância da árvore. Dessa forma, é mais fácil de convencer. A Educação Ambiental é fundamental!"; a técnica do Consórcio declara que para ela, lei é pressão, e não incentivo. Porém, é importante: "Acho triste mas parece que é o jeito."; o presidente do Sindicato e Cooperativa dos Plantadores de Cana, acredita que do jeito que está, não está estimulando: "Não adianta só fazer lei sem fazer um esclarecimento embasado, dando orientação. Deve ser feito um trabalho de base antes de lançar a lei, para que ela seja auto-aplicável"; a consultora do IPEF, afirma que o instrumento legal pode ser interessante, pois instiga a discussão, como no caso da Lei de Crimes Ambientais e o Código Florestal; o professor da ESALQ/USP, acredita que "a lei tem poucos itens voltados ao estímulo para o plantio através de estratégias educacionais. A lei hoje, pode ser aprimorada em termos de seus fundamentos, no entanto o trabalho maior deve estar reservado a um coletivo de agentes educacionais e extensionistas de um município que irão estabelecer estratégias de diálogo com os agricultores para todos se responsabilizarem (cada um fazendo a sua parte) com as árvores, florestas, biodiversidade, água, clima, saúde, etc. do Planeta e de cada pessoa"; e o analista do DEPRN, afirma que "A lei não estimula o plantio de árvores. Existe um decreto estadual do Deputado Ivan Valente obrigando a recuperação de todas as áreas de preservação de uma propriedade. A exigência não pegou e não foi para frente. O código florestal lei 4771/65 em seu artigo 16 diz que toda propriedade tem que ter $20 \%$ e isto desde 65 . Também, não pegou. Acho que deveria existir incentivos estaduais e federais para plantio de árvores. É um trabalho vagaroso de convencimento, de educação ambiental, de incentivos, etc. Leis ambientais, o Brasil tem bastante. Basta aplicá-las corretamente através dos órgãos fiscalizadores (Polícia Ambiental), licenciadores ( DEPRN) e dos órgãos aplicadores da lei (MP, Poder Judiciário e Delegacia de Policia). A iniciativa, também de ONGs sérias seria um porta de entrada muito importante. O plantio de árvores isoladas não é a solução para a melhoria das condições ambientais de uma propriedade. O manejo correto do solo, mediante curva de nível, uso de adubos orgânicos, praguicidas naturais, diversidades de culturas e uma política voltada aos interesses sociais e ambientais poderiam melhorar sobremaneira a situação caótica que atualmente se verifica nas cidades e no campo". 
A discrepância explícita de opiniões entre estes diversos profissionais, certamente desencadeia diferentes ações e posturas junto aos proprietários rurais, 0 que pode gerar confusões para os mesmos: Em quem acreditar? Qual a orientação a seguir? O que é melhor para minha propriedade?

Não se pretende aqui, pregar a igualdade de discurso e combater a divergência, mas certamente pode-se afirmar que há um dilema a ser enfrentado: Como o proprietário pode reagir diante desta situação?

Para responder a esta indagação, faz-se necessário se reportar à Revisão Bibliográfica sobre Educação (Item 2.2.1), em especial, às palavras de Freire (1977, p.75 a 77) que afirma que a educação não deve se restringir "depositar informes ou fatos nos educando", mesmo porque, muitas vezes as informações podem ser levadas ao público de maneira tendenciosa, mas deve sim, fornecer elementos para que as pessoas possam fazer suas escolhas de maneira consciente.

\subsection{Palestra de divulgação}

Durante o decorrer da pesquisa, tanto ao aplicar os questionários como em conversas informais com os proprietários rurais, questionou-se quando e qual seria 0 melhor ugar para se realizar a intervenção educacional pretendida. A maioria das pessoas indicou a Usina Costa Pinto, como a melhor localidade por estar sediada próxima às propriedades da Microbacia e por ser conhecida por todos. A princípio, houve receio por parte dos responsáveis pela pesquisa, devido a possibilidade de resistência ao comparecimento por parte de proprietários que não tivessem um bom relacionamento com a usina, porém, interrogando algumas lideranças locais, houve a informação de que não havia oposição à Usina na região, pois a maioria absoluta dos proprietários era fornecedor de cana-de-açúcar para a mesma.

Deste modo, a primeira palestra foi realizada no dia 26 de outubro de 2001, com a intenção de apresentar a proposta de intervenção educacional aos agricultores, marcar as datas para a realização da mesma e colher inscrições. Contou-se com a participação de seis proprietários rurais e dois alunos da Escola Superior de Agricultura "Luiz de Queiroz" - ESALQ / USP interessados no tema e colaboradores. 


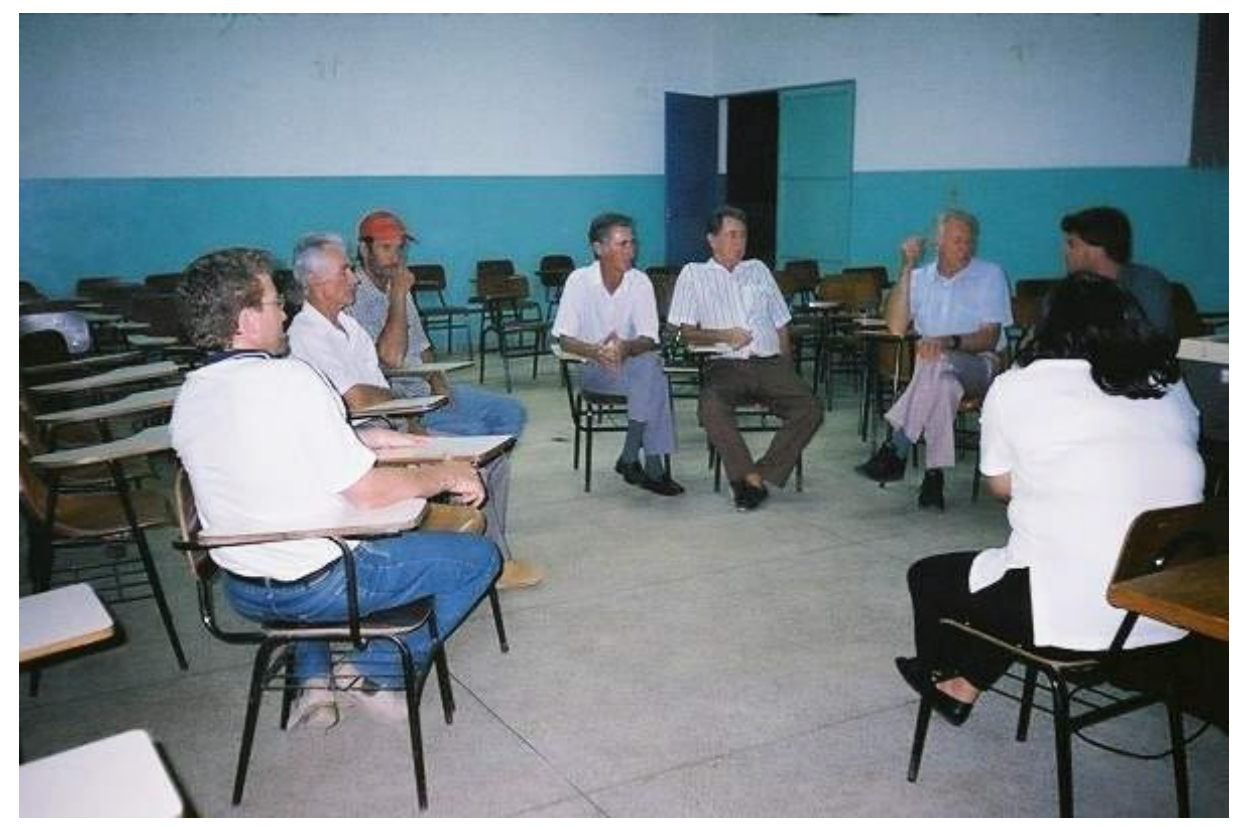

Figura 47 - Palestra de divulgação.

Foram abordados diversos assuntos, iniciando-se pelo questionamento sobre a importância das árvores e florestas; seguindo-se pela exibição de dois vídeos mostrando exemplos de iniciativas que têm dado certo (o primeiro produzido em Conceição do Araguaia/PA, no qual agricultores mostram a importância das árvores para a proteção dos rios e solos; o segundo exibido no programa Globo Rural, em outubro de 2000, em que um professor da ESALQ descreve uma pareceria entre a Universidade e uma Usina de álcool, desenvolvendo ações para a recuperação de áreas degradadas pelo plantio de cana-de-açúcar); realizando-se logo após, um debate sobre a degradação ambiental e o surgimento de leis florestais, seus objetivos, importância e conteúdos; qual a importância de atitudes individuais e coletivas num contexto de bacias hidrográficas, etc. Foram deixadas várias perguntas em aberto, para despertar o interesse dos agricultores em participar das próximas palestras, cujas datas foram marcadas antes do encerramento da palestra, e cujos temas surgiram de questionamentos do participantes no decorrer do encontro. Deste modo, ficou agendada duas outras reuniões, uma com o DEPRN, visando esclarecer questões sobre a legislação florestal, e uma com o Consórcio Intermunicipal de Bacias Hidrográficas para esclarecer dúvidas sobre programas de auxílio ao reflorestamento. 
Apesar do esforço em fazer uma divulgação personalizada, com entrega de convites pessoalmente e telefonemas, além da realização do encontro em horário e local sugeridos pelos proprietários rurais da Microbacia estudada, observou-se um pequeno comparecimento nesta primeira palestra.

Questionados sobre os motivos desta baixa participação, um dos proprietários presentes declarou que o ocorrido não se devia ao horário, nem ao local e divulgação. Segundo ele, existe entre os proprietários rurais, total falta de interesse pelo assunto abordado na reunião: árvores na propriedade rural. "Ninguém quer saber de plantar árvores e eles têm medo que se vierem aqui, terão que se comprometer a plantar. Assinar alguma coisa..." .

Outras declarações feitas após a realização do encontro, auxiliaram na compreensão sobre o baixo comparecimento: o extensionista da Casa da Agricultura, o engenheiro agrônomo Bovi, declarou que trabalhar com proprietários rurais e conseguir sua adesão para propostas como o plantio de árvores, é muito difícil: "É como dar murro em ponta de faca!", exclamou. O responsável pelo Sindicato dos Trabalhadores Rurais, Sr. Antônio, afirmou que têm notado uma grande apatia e desinteresse dos proprietários rurais em participar de reuniões e cursos. Ele acredita que isto se deve a crise da baixa rentabilidade das culturas, que o setor rural vem enfrentando. Segundo ele, os trabalhadores só tem obtido prejuízos após um ano inteiro de trabalho, o que gera a vontade de mudar de ramo e causa um grande desânimo.

Constatando-se o pouco sucesso no diálogo com os proprietários rurais da Microbacia Tamandupá, optou-se por envolver outros proprietários do município, além de pessoas que atuam e/ou residem na propriedade rural mas não são proprietárias, para que fosse possível avaliar outras alternativas de abertura ao diálogo e influência na tomada de decisões. 


\subsection{Conjunto de Atividades Educacionais}

Este conjunto de atividades buscou subsidiar a elaboração de uma proposta de Intervenção Educacional para proprietários rurais. Para isto, contou-se com a colaboração da Casa da Agricultura de Piracicaba e de Pesquisadores do Laboratório de Educação e Política Ambiental - LEPA, do Departamento de Ciências Florestais da ESALQ/USP.

Atividades realizadas:

08/11/2001: Convite aos proprietários rurais da Microbacia Tamandupá, a participarem de um debate sobre o Código Florestal Brasileiro, promovido pela ESALQ Júnior Florestal. Duração: 4 horas. Local: ESALQ/USP. Convites feitos por telefone.

20/11/2001: Envolvimento de proprietários rurais da Microbacia Tamandupá, com agricultores da Microbacia Campestre (área de trabalhos intensivos da Casa da Agricultura). Os proprietários do Tamandupá foram convidados a participarem de uma palestra sobre Legislação Ambiental, realizada no Centro Comunitário do Bairro Campestre, com a colaboração de técnicos da CATI, da CETESB e do DEPRN. Duração: 4 horas. Os convites foram distribuídos pessoalmente, com oferecimento de transporte para aqueles que não tinham como se deslocar até o local da palestra.

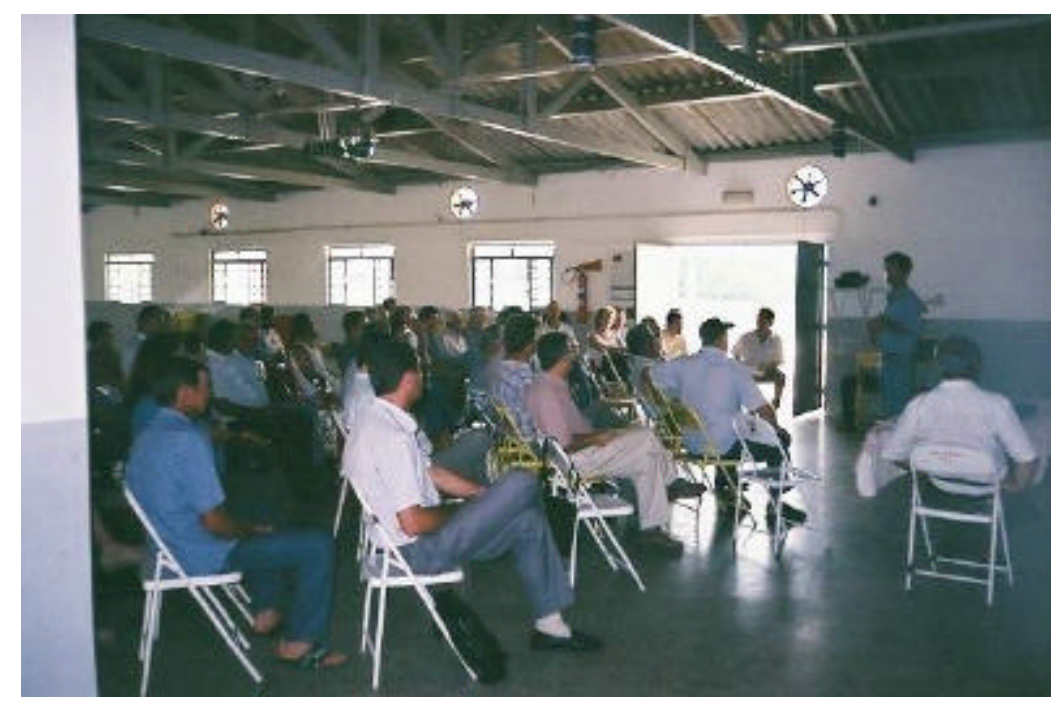

Figura 48 - Palestra organizada pela CATI. 
03/12/2001: Palestra sobre Programas de Auxílio ao Reflorestamento e Proteção ao Meio Ambiente, realizada na Cooperativa dos Plantadores de Cana-de-açúcar, contando com a participação do Consórcio Intermunicipal de Bacias Hidrográficas e de proprietários rurais de outras regiões que participam de programas de reflorestamento. Duração: 4 horas.

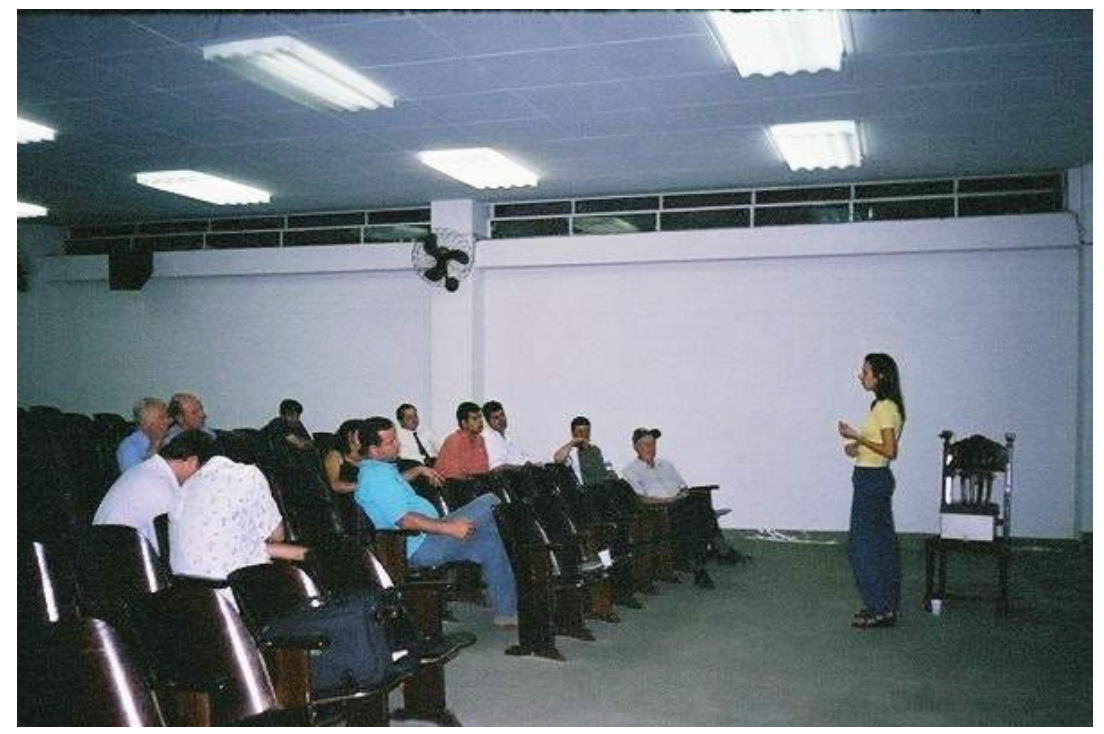

Figura 49 - Palestra sobre Programas de Auxílio ao Reflorestamento e Proteção ao Meio Ambiente.

17/12/2001: Palestra sobre Legislação Florestal e Participação Pública. Participação do Prof. Dr. Marcos Sorrentino. Local: Auditório da Cooperativa dos Plantadores de Canade-açúcar. Duração: 4 horas. (Este evento foi cancelado devido ao não comparecimento dos proprietários rurais).

\subsection{Curso Idealizado}

Após a realização das atividades citadas no item anterior, buscou-se elaborar uma proposta de intervenção educacional em forma de curso abordando os principais assuntos de interesse dos proprietários rurais. Os objetivos gerais traçados especialmente para este curso encontram-se abaixo enumerados: 
1. Disponibilizar informações contextualizadas sobre legislação florestal e proteção ambiental;

2. Instigar a atuação voluntária dos proprietários na recuperação e conservação de ambientes naturais, através da sensibilização dos mesmos;

3. Incentivar o exercício da cidadania e auxiliar a organização popular;

4. Auxiliar os proprietários a observarem sua realidade e a importância de suas propriedades num contexto mais amplo: bacia hidrográfica, país, planeta, futuras gerações;

5. Ampliar os dados e enriquecer as análises sobre a percepção que os participantes possuem a respeito da problemática ambiental e da legislação florestal;

6. Oferecer subsídios para a geração de diretrizes para políticas públicas voltadas à participação dos agricultores na incorporação de árvores em suas propriedades;

7. Procurar instigar o resgate do ânimo, da auto-estima e da esperança das pessoas que vivem na área rural, através da valorização dos indivíduos e do potencial de ação de cada um, utilizando como instrumento para isto, a Educação Ambiental.

Os procedimentos idealizados com o intuito de satisfazer a estes objetivos são:

- Disponibilizar informações sobre a Bacia Hidrográfica em que estão inseridas as propriedades das pessoas presentes no curso e confrontar estes dados com os problemas ambientais observados pelos proprietários entrevistados;

- Incentivar debates e adoção de posicionamentos através do enfrentamento de uma situação problema associado a uma dinâmica conhecida como Inversão de papéis ${ }^{15}$;

- Efetuar trabalho de campo com o intuito de entender o conceito de Bacia Hidrográfica e as implicações que podem ter os pequenos atos realizados em uma propriedade;

- Exercitar a interpretação de leis florestais, com o objetivo de conhecer e entender as normas, além dos motivos que levaram à sua criação;

- Discutir questões como Direito de Propriedade e Função Social da Propriedade;

- Instigar a organização e a participação dos proprietários em debates sociais sobre assuntos de interesse dos mesmos (Ex.: Alterações no Código Florestal);

\footnotetext{
${ }^{15}$ Nesta dinâmica conhecida como Inversão de Papéis, os participantes são incentivados a se colocarem no lugar dos governantes, dos ambientalistas, dos degradadores, dos legisladores, dos moradores à montante ou à jusante, etc.
} 
- Produzir material didático/informativo em equipes, para que haja maior divulgação das conclusões dos debates e para que seja avaliado o aproveitamento das informações disponibilizadas durante todo o processo. 


\section{CONCLUSÕES}

A presente pesquisa caracterizou-se pela busca por alternativas que auxiliassem na proteção e implementação do elemento arbóreo em uma microbacia da região de Piracicaba. Neste sentido, preocupou-se em relatar os procedimentos adotados para estabelecer contato com proprietários rurais, de modo a promover a aproximação junto aos mesmos e a abordá-los com o intuito de conhecê-los e caracterizá-los. Estes procedimentos visaram fornecer elementos para intervenções educacionais que pudessem auxiliar o público alvo num processo de reflexão e prática em direção à implementação e proteção das árvores e florestas em seus sítios, chácaras e fazendas.

Durante os primeiros contatos junto aos pesquisados, detectou-se algumas dificuldades, principalmente no sentido de localizá-los. A aproximação e o estabelecimento de uma relação de confiança, também não foi fácil. Para isto, foi fundamental a solicitação do auxílio de instituições como a Casa da Agricultura, sindicatos e a cooperativa de plantadores de cana-de-açúcar, além da identificação de moradores mais antigos que forneceram contatos e referências para esta detecção. Notou-se que quanto maior o número de visitas feitas a um proprietário, e quanto mais informal se tornassem as conversas com os mesmos, maior era a qualidade e confiabilidade das informações obtidas: eles se sentiam mais à vontade para dar opiniões e fazer sugestões.

Estas observações levaram à conclusão de que o trato com este público, é complexo e necessita de dedicação e continuidade. Não se pode simplesmente abordar e fazer solicitações, sem dar-lhes o devido retorno.

Quanto às alternativas de aproximação, a aplicação de questionários apresentou méritos, porém, não deve ser considerada como técnica exclusiva neste sentido. 
No decorrer da pesquisa, percebeu-se a necessidade de outras formas de abordagem, como por exemplo, as conversas informais, o contato via sindicato, a participação em eventos comuns a este público (que vão desde congressos até missas e festas). Além disto, acredita-se necessário o envolvimento de outras pessoas e situações que podem influenciar na tomada de decisões. A dedicação de um caseiro, as informações trazidas da escola pelas crianças, o empenho dos cônjuges, podem representar importantes canais de aproximação, motivação e informação.

Os próprios proprietários também devem auxiliar no envolvimento de seus companheiros. Isto porque, muitos demonstram orientar suas ações através da observação de exemplos dos vizinhos ou de experiências positivas de outras regiões. Eles podem ainda, auxiliar na divulgação de eventos e na condução de reuniões. Neste sentido, observa-se que os proprietários que residem no campo, mostram-se mais dispostos e abertos ao diálogo. As perguntas que permitiram diferenciar os proprietários de acordo com sua percepção sobre as árvores e sobre as leis que as protegem, possibilitaram esta detecção. Embora estes agricultores familiares sejam poucos hoje em dia (pois grande parte migrou para as cidades), eles estão mais próximos, mais envolvidos com suas propriedades e, como o questionário aplicado durante a pesquisa demonstrou, possuem melhor percepção e demonstram maior afetividade pelo elemento arbóreo do que aqueles que residem na cidade.

Vale ressaltar, que os proprietários rurais não representam uma categoria homogênea. Possuem características variadas e opiniões diversas.

Neste sentido, propõe-se que as intervenções educacionais sejam amplas, contemplando diversos públicos e procedimentos.

Esta diversidade de abordagens deve incluir, dentre outros conteúdos, mudanças culturais, compreensão da saúde do planeta, dependência das ações integradas, necessidade de fortalecimento dos proprietários rurais, reconhecimento por parte da sociedade e auto-valorização destas pessoas como guardiãs da Natureza. Temas esses, que necessitam ser trabalhados de diferentes maneiras, de acordo com as características de cada grupo.

Para a construção de uma proposta neste sentido, identificam-se alguns procedimentos e sugestões que podem auxiliar a conduzir um projeto de intervenção educacional junto a agricultores. Partindo da experiência adquirida nesta pesquisa, pode-se afirmar que o conhecimento mais aprofundado das pessoas presentes na área 
de estudo é fundamental, mas não deve ficar centrado apenas nos administradores das propriedades. A realização de um diagnóstico participativo voltados às diversas categorias sociais, pode ser uma boa alternativa. A construção de um projeto de extensão direcionando atividades específicas para cada grupo, é também aconselhável.

Um projeto de intervenção deve ainda, buscar parcerias com profissionais que atuam no setor rural e promover a aproximação do público junto aos mesmos, bem como incentivar a integração entre os produtores para exigir a eficácia das instituições relacionadas com o setor. Deve-se identificar problemas e traçar caminhos para a solução dos mesmos. A elaboração de um projeto coletivo que aponte para a organização setorial e para a busca de maior participação de agricultores e proprietários rurais em geral, em processos de tomada de decisões é um produto desejável, que pode ser sugerido por um facilitador ou mediador do encontro.

Além disto, a despeito dos dados advindos da pesquisa de campo não fornecerem elementos objetivos para estas afirmações, vale ressaltar a importância de um trabalho educacional que prepare os proprietários rurais para o trato de questões políticas associadas à legislação. Neste sentido, uma intervenção educacional deve, por exemplo, auxiliar os proprietários rurais no enfrentamento das divergências entre os setores ambientalistas e ruralistas, buscando eliminar preconceitos e caminhando para a parceria. Nota-se um grande movimento no sentido de promover a inimizade entre estes setores, afirmando que os mesmos encontram-se em lados opostos. Deste modo, torna-se imprescindível o bom discernimento de ambas as partes, no sentido de avaliar o trabalho em conjunto como uma possibilidade de benefício mútuo. Com a promoção do debate, com o estabelecimento de críticas construtivas e com a adoção da consciência e coerência nas negociações, aumenta-se a possibilidade de entendimento e de superação dos conceitos pré-estabelecidos. É claro que o meio ambiente não é moeda de troca, como afirmou-se durante as discussões sobre as alterações no Código Florestal em vigor, e não pretende-se aqui, afirmar que é preciso ceder de uma lado para conseguir o que se quer do outro. Ao contrário, propõe-se que sejam avaliadas as reais necessidades de proteção lembrando-se que todos serão beneficiados, inclusive os proprietários rurais.

No caso de necessidade de recuperação de uma mata ciliar, por exemplo, os proprietários rurais devem considerar o fato de estarem utilizando uma área que nunca 
deveria ter sido desmatada, pois a própria Natureza indica a necessidade de sua existência (como abordado na Revisão da Literatura), e que, o fato de terem adquirido uma propriedade em determinado grau de degradação, não os isenta da responsabilidade sobre seu melhoramento e manutenção. Por outro lado, a sociedade como um todo, deve também assumir seu interesse nesta recuperação, podendo apontar maneiras de auxiliar e recompensar os proprietários que estejam beneficiandoa. Pode-se dizer, que este dilema não possui soluções mágicas, mas existem discussões no sentido de estabelecer algumas alternativas de compensação aos proprietários rurais que contribuem para a conservação de águas e florestas.

Dentre estas alternativas que buscam incentivar os proprietários para 0 reflorestamento, destacam-se algumas que têm sido amplamente discutidas (ressaltando-se aqui, que não se pretende defender qualquer uma destas idéias, apenas chamar a atenção para sua existência): a possibilidade de se identificar os "produtores de água" e de utilizar verba proveniente da cobrança pelo uso da água, para incentivá-los; atribuir valor pelo "seqüestro de carbono", ou seja, pela contribuição que as florestas trazem na transformação de gás carbônico em oxigênio; fortalecer uma economia florestal regional, trazendo renda àqueles que cultivarem árvores com fins comerciais ou que substituírem suas culturas temporárias por culturas perenes florestais; potencializar o turismo ecológico; possibilitar a compensação de Reserva Legal Florestal em outras propriedades, dentro de limitações ecológicas e econômicas, devidamente regulamentadas trazendo renda aos proprietários que possuírem áreas florestadas excedentes ao exigido por lei; realizar ações experimentais que permitam a utilização de espécies exóticas plantadas œm finalidade econômica, para servirem como primeira etapa de sucessão florestal em processos de reflorestamento e recuperação de áreas degradas (reconhecendo que este procedimento seja ainda bastante polêmico); diferenciar pequenos e grandes proprietários no que tange à disponibilização de benefícios e auxílios à implantação de árvores em propriedades rurais (dando maior apoio aos pequenos); facilitar a comercialização e promover a valorização de produtos florestais obtidos através de manejo adequado de Reservas Legais.

Estas medidas citadas acima, podem trazer benefícios ou prejuízos ao meio ambiente e às pessoas do campo, de acordo com a maneira em que sejam adotadas. Por isto, devem ainda ser bem discutidas e implementadas apenas quando as dúvidas 
quanto aos seus riscos estiverem esclarecidas e quando os procedimentos para sua aplicação forem descritos claramente. Para que isto ocorra, torna-se cada vez mais necessária a promoção da sinergia entre as áreas de educação, legislação e política no trato destas questões.

A educação pode contribuir para o questionamento e para as atuações no sentido de promover a adequação das leis, enquanto estas, devem direcionar a criação de políticas que visem a real proteção e implementação do elemento arbóreo.

Para exemplificar, pode-se dizer que o direito ambiental, com seus princípios, leis e normas, pode ser considerado um valioso instrumento na defesa do meio ambiente. Porém, ele não terá a mesma eficácia se aplicado sem o acompanhamento de medidas educacionais sérias. Isto porque, sem o conhecimento da Lei e sem a clara noção de sua importância para a promoção do bem comum e dos motivos de sua criação, pode ocorrer o efeito contrário ao desejado pelos legisladores ao elaborar as leis ambientais. O desconhecimento da lei, a punição sem o devido esclarecimento (surpreendendo o proprietário rural) e a desigualdade no trato entre pequenos e grandes produtores, pode desencadear uma revolta, um desagrado em relação à legislação e às políticas ambientais, como demonstrado em depoimentos feitos pelos entrevistados. Deste modo, as pessoas acabam por não se sentirem motivadas a contribuir para um mundo melhor, e muitas vezes são levadas a buscar meios de sobreviver se esquivando de compromissos maiores com a coletividade e com as futuras gerações.

Neste sentido, cabe ressaltar que não é apenas a promoção da informação, valorização da Natureza e da proteção ambiental, que bastará para que a qualidade de vida das presentes e futuras gerações seja assegurada: deve haver condições dignas de vida, que possibilite o acesso à educação e à cultura, que leve as pessoas a quererem e a batalharem pela qualidade de suas relações, de seus alimentos, do seu ambiente, etc., para que estas não fiquem "cegas" na ânsia de conseguirem as condições mínimas de sobrevivência. Deve-se também, trabalhar questões como o imediatismo que leva a sociedade a pensar no lucro rápido, não valorizando ações que visem benefícios a longo prazo.

Este tipo de comportamento, pode propiciar o uso de questões econômicas como desculpa para se ignorar medidas sociais que não apresentem resultados 
instantâneos ou que não estejam diretamente relacionadas à superação da miséria e da fome. É claro que este atos são importantes. Esquece-se porém, que não adianta ter comida e segurança, se não houver ar para respirar e água para beber! Assim, a busca pela melhoria das condições de vida e de trabalho (tanto no campo como na cidade), deve andar paralelamente à luta por um mundo saudável e um ambiente sustentável.

Nesta direção, a educação, a informação contextualizada e a participação, podem ser consideradas uma excelente opção. As pessoas precisam ter acesso ao conhecimento sobre alternativas que possam trazer mudança em suas condições de vida, devem também, ser motivadas a buscar estas alternativas e merecem receber auxílio para sua organização social. Além disto, precisam potencializar-se para realizar escolhas e a tomar decisões e atitudes. A realização de intervenções educacionais pode e deve auxiliar neste busca.

Porém, não se pode esquecer de ir além da demonstração da importância da proteção ambiental para a sobrevivência dos seres humanos, e, promover a valorização da biodiversidade, dos ecossistemas, da interação entre animais e plantas, do simples direito à sobrevivência que todos os seres possuem, etc. Pede-se ainda, o incentivo à reflexão sobre as responsabilidades de cada indivíduo, a necessidade de participação política, o exercício da cidadania e o sentimento de pertencimento à Natureza, auxiliando na interiorização da preocupação ambiental.

Com isto, pode-se dizer que apesar do processo de busca por alternativas que auxiliem na promoção da proteção e implementação do elemento arbóreo em propriedades rurais seja árduo, é possível e pode ser extremamente gratificante se encarado com seriedade, coragem e, sobretudo, amor. 
ANEXOS 


\section{ANEXOS}

Página

Anexo A: Questinário aplicado................................................................... 136

Anexo B: Questionário sugerido pela engenheira agrônoma responsável pela Casa da Agricultura de Piracicaba..................................................................... 139

Anexo C: Transcrição das entrevistas........................................................ 141

Anexo D: Mapa da Rede Hídrica da Microbacia Tamandupá............................... 171

Anexo E: Mapa de Cobertura Florestal da Microbacia Tamandupá........................ 172

Anexo F: Atividades realizadas durante o desenvolvimento da pesquisa.............. 173

Anexo G: Sugestão de Programa de Educação Ambiental para a Bacia do Rio Corumbataí, apresentado ao IPEF / SEMAE em junho de 2001.................... 177 


\section{ANEXO A. Questionário Aplicado}

Nome do proprietário:

Escolaridade:

Nome da propriedade:

Endereço para correspondência:

Roteiro de acesso:
Data de nascimento:

Município:

Área da propriedade:

Telefone:

\section{* Sobre a propriedade:}

1. Há quanto tempo a propriedade pertence a este dono?

2. O proprietário reside na área? Possui outras propriedades (total das outras propriedades)?

3. Alguma atividade econômica é desenvolvida na propriedade? Qual?

4. Quando o senhor adquiriu a propriedade, existia mata? Como era (as espécies de árvores, a localização, ...)?

5. Como a propriedade é hoje em relação à cobertura de árvores (quanto, onde e por que)?

6. Existe alguma mata em sua propriedade, que tenha sido averbada (declarada ao poder público) como Reserva Legal?

7. Você tem percebido alguma mudança (transformações) no ambiente (Clima, solo, qualidade de água, animais, vegetação, ...)?

Caso positivo: A que você atribui esta(s) mudança(s)?

8. Usa água de poço? Por que?

9. Tem nascentes na propriedade? Como elas estão hoje (quantidade / qualidade)? Você utiliza esta água?

10. Você já plantou árvores em sua propriedade? Isoladas ou formando matas? Com que finalidade? Com espécies nativas ou exóticas?

11. Plantaria (outras, caso já tenha plantado)? Por que, para que e de que tipo?

12. O que o levaria a não plantar árvores nativas na propriedade? (espaço, dinheiro, mão de obra, etc).

13. Qual a importância que as árvores isoladas (aquelas espalhadas próximo às casas, na entrada, frutíferas, etc) tem para o senhor? 
14. Sua propriedade apresenta problema de erosão (tipo voçoroca)? Como é esta área?

15. Sua propriedade possui faixas de floresta ao longo dos rios? Por que? Qual a metragem?

16. Você se sente prejudicado por algum dano ao meio ambiente praticado em alguma propriedade próxima (vizinho)? O que você acha que deveria ser feito a este respeito?

17. É bom estar numa bacia de abastecimento de água para Piracicaba? Por que?

18. O que você sonha para a sua propriedade no futuro ?

\section{*Opiniões:}

19. Na sua opinião, para que servem as florestas e as matas?

20. Elas (florestas e matas) devem ser protegidas? Por que?

21. Qual é o tipo de vegetação que deve ser protegido e qual o tipo que pode ser derrubado? Por que?

22. Você acha que a mata ciliar realmente protege os cursos d'água? Como?

23. Você acredita que a fauna silvestre deve ser protegida? Por que?

24. O que você acha das pessoas que põe fogo proposital na floresta ou mata, ou derrubam árvores que devem ser preservadas? Elas devem ser punidas?

25. Você sabe que existem leis que cuidam das matas?

( ) Sim. ( ) Não.

Para as respostas afirmativas: O que você pensa sobre estas leis (são boas, ruins, têm sido obedecidas, ,...)?

26. Você conhece o Código Florestal Brasileiro?

Para aqueles que conhecem o Código Florestal:

Você o acha adequado? O que lhe chama mais atenção?

27. O que você acha que deve ser feito para que as leis florestais sejam cumpridas?

28. De quem você acha que é a obrigação de proteger a Natureza?

29. Na sua opinião, de quem deveria ser a água que está dentro de sua propriedade (direito)? E de quem deveria ser a responsabilidade sobre ela (dever)?

30. E a faixa na beira dos cursos d'água? De quem deveria ser a responsabilidade de preservá-la / plantá-la? 
31. Você já ouviu falar de alguma campanha ou programa de auxílio ao florestamento em propriedades rurais? Qual?

Para as respostas positivas:

Este programa Ihe pareceu bom? Você aderiu ou gostaria de aderir a ele?

32. Você conhece alguma propriedade que tenha tido alguma área reflorestada? Caso positivo, você sabe no que isto ajudou ou atrapalhou a propriedade e o proprietário?

33. Você gostaria de participar de algum curso sobre preservação da natureza e legislação do meio ambiente? Onde e quando gostaria que fosse o curso? (Época do ano e horário).

34. Qual a melhor forma de contactá-lo?

35. Você gostaria de receber mais informações sobre:

( ) Programas de auxílio ao florestamento.

( ) Legislação florestal.

( ) Proteção à Natureza.

( ) Alternativas econômicas envolvendo árvores.

( ) Técnicas de plantio de árvores.

( ) Outros: 


\section{ANEXO B. Questionário Sugerido pela Responsável pela Casa da Agricultura de Piracicaba}

Nome do proprietário:

Escolaridade:

Nome da propriedade:

Endereço para correspondência:

Roteiro de acesso:

Data de nascimento:

Município:

Área da propriedade:

Telefone:

1) Reside na propriedade?

2) Há quanto tempo adquiriu a propriedade?

3) Quais as culturas existentes na propriedade?

4) Existia mata quando a propriedade foi comprada?

5) Com o tempo, o mato diminuiu? Como e quando aconteceu?

6) Hoje você percebe alguma mudança?

( ) Na terra de plantio;

() Com peixes, aves ou animais;

() Na mata de Barroca ou mata ciliar;

( ) Nos ribeirões ou no rio Corumbataí;

( ) Outra mudança

7) Porque você acha que aconteceu esta mudança?

8) Existe alguma reserva florestal (legal) na sua propriedade? (Averbada?)

9) Tem água na propriedade?

10) A água é usada para:

( ) Beber;

( ) Limpeza;

( ) Irrigação;

( ) Criação;

( ) Piscicultura;

( ) Outros

11) Na sua opinião a mata deve ser protegida? Por que?

12) Existem árvores que podem ser derrubadas? Por que?

13) Você acha que a mata ciliar e os animais silvestres devem ser protegidos? Por que? 
14) O que você acha sobre as pessoas que queimam ou derrubam a mata? Devem ser punidas?

15) Você sabe que existem leis que protegem a mata? Conhece o Código Florestal Brasileiro?

16) As leis devem ser obedecidas? Qual sua sugestão para que sejam cumpridas?

17) De quem é a obrigação de proteger a natureza?

18) Na sua opinião de quem é a água existente na sua propriedade e quem deveria cuidar dela?

19) Quem deveria plantar e cuidar da mata ciliar?

20) Você conhece algum programa que ajuda o florestamento na propriedade?

( ) Sim. Qual?

( ) Não

21) Se conhece, o que acha do programa? Gostaria de participar dele?

22) Você conhece alguma propriedade que foi florestada? Acha que ajudou o proprietário?

23) Você plantaria árvores nativas na sua propriedade?

24) Já fez algum reflorestamento na sua propriedade? Com que finalidade?

25) Você já se sentiu prejudicado por algum vizinho em questão do meio ambiente? O que você fez ou faria se isso acontecesse?

26) Você acha interessante morar nas margens do rio que abastece água para Piracicaba? Por que?

27) O que você espera fazer no futuro (na propriedade)?

28) Você gostaria de participar de algum curso sobre preservação da natureza e legislação do meio ambiente? Onde gostaria que fosse o curso? 


\section{ANEXO C. Transcrição das entrevistas}

PROPRIETÁRIOS RURAIS / TAMANDUPÁ - RIO CORUMBATAÍ

\begin{tabular}{|c|c|c|c|}
\hline PROP. & IDADE & ESCOLARIDADE & ÁREA (alq.) \\
\hline 1 & 60 & Superior. & 6,4 alq. \\
\hline 2 & 66 & 4a série. & 5 alq. \\
\hline 3 & 52 & Superior (Adm.) & 11 alq. \\
\hline 4 & 43 & Superior. & 4,5 alq. \\
\hline 5 & 81 & 1a Série. & 6 alq. \\
\hline 6 & 31 & 2o. Colegial. & 3,5 alq. \\
\hline 7 & 77 & 40. Ano primário. & 11 alq. \\
\hline 8 & 44 & 10. Grau. & 40 alq. \\
\hline 9 & 75 & 40. Ano primário. & 12 alq. \\
\hline 10 & 59 & 40. Ano primário. & 17 alq. \\
\hline 11 & 54 & Colegial. & 18 alq. \\
\hline 12 & 40 & 40. Ano primário. & 11 alq. \\
\hline 13 & 67 & Ginásio. & 122 alq. \\
\hline 14 & 54 & Eng. Agrônomo. & 13223,2 alq. \\
\hline 15 & 60 & Médio. & 170 alq. \\
\hline 16 & 50 & Superior. & 32 alq. \\
\hline 17 & 44 & Médio. & 7 alq. \\
\hline 18 & 44 & Superior. & 10 alq. \\
\hline 19 & 61 & 4a. Série. & 4,5 alq. \\
\hline 20 & 41 & 4a. Série. & 3.5 alq. \\
\hline 21 & 53 & Superior. & \\
\hline 22 & 84 & 3o. Colegial. & 10 alq. \\
\hline 23 & 41 & 3o. Colegial. & 7 alq. \\
\hline 24 & 44 & 4a. Série. & 8 alq. \\
\hline 25 & 67 & Magistério. & 8 alq. \\
\hline 26 & 48 & 10. Grau Completo. & 15,7 alq. \\
\hline 27 & 52 & 10. Grau. & 31,4 alq. \\
\hline 28 & & & 9,2 alq. \\
\hline 29 & 63 & 4a. Série. & 6,7 alq. \\
\hline 30 & 50 & Superior. & 80 alq. \\
\hline
\end{tabular}

Quadro 8-Características dos entrevistados.

Q.1. Há Quanto tempo a propriedade pertence a este dono?

1. +-50 anos.

2. +- 50 anos.

3. Ao meu pai, 70 anos.

4. 10 anos.

5. Nasci em outro sítio e vim para este em 1924.

6. 6 anos.

7. Toda vida. Foi do meu pai. 
8. +- 60 anos.

9. 64 anos.

10.Desde 1955.

11. 1 ano e meio.

12. 40 anos.

13. 32 anos. Nasci em Rio Claro.

14. Entre 40 e 50 anos.

15. 15 anos.

16. +- 1 ano.

17. Há 20 anos.

18. 8 anos.

19. 30 anos. Há três gerações minha família está no local.

20. 3 gerações.

21. 29 anos.

22. Há 50 anos.

23. Desde 1986, a aproximadamente 15 anos.

24. Há muitos anos (mais de 60).

25. Há mais de quarenta anos.

26. 25 anos.

27. +- 25 anos.

28. Muitos anos (mais de 60).

29. A propriedade foi herdada do meu sogro a 25 anos.

30. 18 anos.

\section{Q.2. O proprietário reside na área? Possui outras propriedades rurais?}

1. Não. / Não.

2. Sim. / Sim.

3. Sim. / E tenho mais quatro sítios somando 42 alq..

4. Não. / Arrendo a mais de 10 anos só para pagar ITR. Não dá lucro nenhum./ Possuo outras propriedades junto com irmãos.

5. Sim. / Possuo outros sítios.

6. Não. / Não.

7. Morei mais de 50 anos. A 10 anos moro na cidade. / Sim.

8. Não. Moro em Charqueada. / Mas tenho a casa na propriedade também.

9. Sim. / Não. $90 \%$ da minha renda vem do sítio. $10 \%$ aposentadoria.

10. Sim. / Não.

11. Não. / Não.

12. Sim. / Não.

13. Sim. / Tenho outras propriedades. Somando todas, dá 950 alq. Uma delas é em Altinópolis.

14. Não. / Não.

15. Não. / Não.

16. Não. / Não.

17. Não. / Possuo outra propriedade em Goiás.

18. Não/ Não.

19. Sim, moro aqui. / Não possuo outras propriedades.

20. Sim. / Sim. Três lotes, somando-se ao total 25 alqueires.

21. Não. / Não.

22. Sim, resido na área. / Possuo um sítio com dois alqueires. 
23. Não. / Não.

24. Não. / Não.

25. Não. / Possuo mais duas propriedades no município de Iracemápolis.

26. Não. / Possuo outra propriedade. Meu irmão é quem cuida da propriedade.

27. A proprietária não residia no local. / Possuía outras propriedades.

28. Não. / Não.

29. Não. / Possuo outra propriedade em Cachoeira Comprida.

30. Não. / Não.

\section{Q.3. Alguma atividade econômica é desenvolvida na propriedade? Qual?}

1. Cana (com adubo).

2. Cana. O resto é só para o gasto. Vassoura, milho. Tem algum gado para limpar a terra. Fiz pasto onde a máquina não passa.

3. Cana (10 alq.). E um pastinho de leite.

4. Só cana. Tem algumas árvores frutíferas para consumo da família.

5. Só cana (2 alq.). Tenho um pouco de pasto. Perto da cidade não pode plantar muito. $O$ pessoal pões fogo.

6. Cana.

7. Só cana. Arrendo para terceiros. Fornecedores de cana.

8. Porto de areia e agropecuária (gado de corte e leite).

9. Possuo 3 alq. de milho e um pouco de pasto. Mas como não está dando renda, vou arrendar para cana.

10. Cana. Vassoura, bem pouco (para quebrar galho).

11. Pasto. Pretendo plantar cana, já foi arrendado. Possuo 1 alq. de milho, 1/2 alq. de mandioca. Pretendo investir em carneiro e apicultura. $O$ eucalipto foi arrancado.

12. 8 alq. de cana (planto 6, deixo 2 descansando). 1,5 alq. De pasto. 1/4 de eucalipto. 1/8 alq. de mato.

13. Cana e leite. Milho para consumo da fazenda.

14. Cana.

15. Cana. Um pouco de gado e um pouco de milho ( Em 2000 deu 300 sacas, em 2001 deu 200 sacas).

16. Porto de Areia e Pasto.

17. Gado e carneiro, mas é somente para os custos de mão-de-obra do caseiro.

18. Pequena produção de gado de corte.

19. Plantio de cana de açúcar com objetivo de venda para a usina Costa Pinto.

20. Cana para venda à usina e para caldo-de-cana, cereais (feijão, milho) e pesqueiro.

21. Não.

22. Principais atividades econômicas são olaria e cana-de-açúcar.

23. Produção de cana-de-açúcar.

24. Produção de cana-de-açúcar.

25. Sim. Cana-de-açúcar.

26. Há apenas pastagem nas propriedades, com pequena atividade pecuarista.

27. Boi para engorda e venda.

28. Não são desenvolvidas atividades econômicas na área.

29. A propriedade possui cana que é vendida para a Usina Costa Pinto.

30. Sim, crio gado.

\section{Q.4. Quando o senhor adquiriu (comprou) a propriedade, existia mata?}


1. Não, sempre teve cana.

2. Não. Só perto das nascentes e nas barrocas.

3. Quando meu pai comprou tinha nas partes altas. Não tinha madeira de lei.

4. Tinha do lado do córrego. E alguns eucaliptos junto com o pasto. +- 200 pés (3/4 de alq.).

5. Tinha pouca: 1 alq. num pedaço mais para o alto. Eu e meus quatro irmãos limpamos para plantar.

6. Quando comprei, não existia mata, só cana.

7. A mais de 50 anos tinha mato na beira do rio. Acabou tudo. O rio levou.

8. Já era limpo. (O antigo prop. criava carneiro de lã).

9. Sim. Tinha 3 alqueires sem, o resto era mata. Com madeira de toda variedade.

10. Tinha menos mata do que hoje. Já tava tudo derrubado.

11. Tinha um talhão com 3 alq. de mata. Próximo a casa não tinha nem pé de manga.

12. Não.

13. O que tinha está preservado. No morro. 12 alq..

14. São muitas propriedades diferentes. Cada uma com uma situação particular.

15. Sim. Mas eu plantei bastante muda também.

16. Um pouquinho na área inclinada (+- $500 \mathrm{~m} 2)$. Só cana na beira do rio.

17. A propriedade era utilizada para plantio de cana-de-açúcar.

18. Sim, a mesma que ainda existe nos dias atuais, mata nativa. Nunca foi explorada.

19. Não, desde os tempos do meu avô, a área já se encontrava em estado de degradação.

Havia uma matinha que pertencia a um espanhol foragido da polícia.

20. Sem mata, tal como atualmente.

21. Sim, ocorre uma mata localizada ao longo do rio.

22. Não havia mata quando adquiri a fazenda.

23. Não. Não conheço.

24. Não. Existia apenas alguns brejos.

25. Não. Não existia árvores.

26. Após a compra, houve melhoria da mata na propriedade. Não mexi na mata desde a compra, houve recuperação natural da floresta.

27. Um pouco, houve melhora.

28. Um pouco, próximo ao córrego.

29. Não.

30. Só nas nascentes e na beira do rio. Menos de $1 \mathrm{~m}$.

\section{Q.5. Como a propriedade é hoje em relação à cobertura de árvores (quanto e onde)?} 1. A mais ou menos 4 anos, deixei a beira do ribeirão sem mexer. 30 metros. Já tem algumas árvores.

2. Hoje tem $3 / 4$ de alqueire de mata. Deixamos a área e está reflorestando sozinha.

3. Cana. Na margem do rio, cerquei uma parte e meu filho plantou mudas feitas por ele mesmo. Mas o pessoal vai e destroi tudo.

4. Cana e pasto. O sítio não faz fronteira com o rio. Tem um córrego com pasto ao lado. Tem gado. Em um dos outros sítios, tem 4 ha de mata nas baixadas.

5. Hoje tem mais ou menos $1 / 4$ de alq. de mata na beradinha do rio. Tem 3,5 alq. de pasto (45 cabeças) e o resto é cana. / Tem também uns 100 pés de eucalipto. As árvores na beira do rio, a turma põe fogo para usar a prainha.

6. Sem árvores.

7. Deixei os 50 metros ( 1,5 alq.), mas quando tá saindo alguma árvore, os bandidos tacam fogo. Antes o povo tinha educação. Hoje ninguém respeita mais. As pessoas põe fogo (maconheiro, etc.). Vândalos. Para dar prejuízo para a gente. A lei tem que ser mais severa para punir esta turma de 16 anos. Eles acostumam a não trabalhar. Tinha que começar a trabalhar com 8 anos. 
8. Tem uns paus-d'álho, cedrinho. Do lado de lá do rio, é da usina. Tem uma ponta de reserva ( 0,2 ha) deixada por causa do Plano de Preservação porque fiz Eia/Rima para conseguir licença do porto de areia.

9. Hoje tem capoeira, barroca e alguma mata, somando 3 alq.. 2 capão e a beira do ribeirão.

10. Já formou mata onde não pode plantar. Na barroquinha.

11. Igual. Plantei algumas frutíferas.

12. Só os $1 / 8$ de alq..

13. Plantei na margem do rio, nos açudes. Com projeto.

14. São muitas propriedades diferentes. Cada uma com uma situação particular.

15. Deixamos $50 \mathrm{~m}$ e estamos reflorestando.

16. Foi plantado devido a exigência legal.

17. Existe um pomar e algumas árvores para arborização.

18. Existe uma larga faixa (acima das medidas mínimas) ao longo do rio e várias árvores na propriedade.

19. Há um pomar e bastante árvores plantadas próximo à sede.

20. Há mais cobertura vegetal que antigamente.

21. Um alqueire e meio de mata.

22. Tem eucalipto, Ipê, Manga, Jabuticaba, Goiabas.

23. Precária, quase não existe.

24. Do mesmo jeito, só que tomamos mais cuidado.

25. Não existe em relação a arborização. Existe somente uma nascente no sítio.

26. A propriedade, basicamente é composta por pastagem, porém há bastante floresta na beira do Corumbataí.

27. Tem bastante.

28. A cobertura vegetal já está sendo recuperada.

29. Houve duas tentativas de recuperação da área. Mas atualmente não há cobertura arbórea.

30. O que tinha antes está preservado.

\section{Q.6. Existe alguma mata em sua propriedade, que tenha sido averbada (declarada ao poder público) como Reserva Legal?}

1. Não.

2. Existe floresta em terreno acidentado (0,5 alq. nesta propriedade e juntando todas, 1,5 alq. de mata num total de 18 alq.). Mas não foi averbada.

3. Não. Em um dos outros sítios, tem 0,5 alq. de mata, mas não averbei.

4. Não.

5. Não.

6. Não.

7. Não. Declarei 2 alqueires que é só mata em outro sítio.

8. Não.

9. Não. Porque não medi.

10. Não.

11. Não.

12. Não.

13. Já declarei.

14. Sim.

15. Não.

16. Não.

17. Não.

18. Não. 
19. Não. Gostaria de saber mais sobre reposição florestal, metragens, espécies, etc.

20. Não.

21. Sim.

23. Não.

24. Não.

25. Não.

26. Não há nada registrado em cartório.

27. Não.

28. Não.

29. Não.

30. Não. Porque gosto de ter liberdade. Quero preservar por vontade, não porque sou obrigado. E mesmo que seja descontado o imposto da área, é tão pouco que não vale a pena.

\section{Q.7. Você tem percebido alguma mudança (transformações) no ambiente? A que você atribui esta(s) mudança(s)?}

1. Tenho problema com mosquito. / Por causa do restilo da usina.

2. Hoje tem muito sol e tempestade. Antes chovia 3 dias seguidos. Melhorou a água porque a usina não joga mais restilo. Herbicida e adubo já são usados a mais de 20 anos e tem que usar cada vez mais. / Não sei porque mudou o clima.

3. De forma geral, no clima. / Deve-se à falta de chuvas.

4. Não.

5. A terra foi enfraquecendo. Plantava sem arar. Hoje está ruim porque deixei passar a rede de esgoto pela propriedade. Quando rompe, espalhama pelo pasto. / A terra está ruim porque a chuva vem como tromba d'água. Antes chovia mais fraco e por vários dias seguidos. Agora vem tudo de uma vez.

6. Não.

7. Sim. Falta de chuva. Mais calor. As terras estão cansadas, são 70 anos plantando. Não pesco

mais. Fiquei aborrecido porque teve uma época que só tinha peixe morto. / Solo fica fraco como pessoa. Falta de meio ambiente. Mata árvore. Onde tem mata é fresco, mas lá, foi surgindo cidades.

8. A água do Corumbataí está boa. Diminuiu animais (aves). / Avião passa pulverizando a cana.

9. Chove menos. O sol é mais quente. Quase toda a terra tem lage embaixo. / Derrubaram muita mata e então diminuiu as águas. Tem lugar que derrubaram até vertente. Plantio de cana estraga a barroca e entope tudo. Estora curva de nível. Eu pego o risco da água e faço curva de nível. Depois que começaram a passar máquina, afundou o caminho e não tem mais jeito. 10. O solo é mais desgastado. Nos anos, na mesma cultura, desgasta. Acho que chove diferente. Vem como temporal. Mudou. Pode ser que em alguns anos volte./ É pelos astros, pelas estrelas. O cruzeiro do sul virou de uma noite para a outra. Pode ter alguma ligação! 11. Agora é que esta dando peixe. Estamos povoando com frutas e árvores. A terra não é muito boa (regular). Os bolsões de areia mudaram o curso das nascentes, mas continuam grandes. 12. Só piorou. O tempo não é mais como antigamente. A chuva não vem na hora certa. / Desmatamento.

13. Cada ano tá diminuindo a chuva. / O pessoal fala que é desmatamento, mas não sei não. / Tem muito raio este ano também.

14. É difícil dizer. A área é muito restrita para ter influência marcante.

15. Sim. Está mais quente. / Porque faltam árvores.

16. Tem muita coisa acontecendo. / Mas ninguém vai admitir que a culpa é dele.

17. Não.

18. Sim. A nascente produz mais água, tem menos peixe do que havia alguns anos no rio e é mais difícil ver alguns bichos na mata do que antes (capivara, por exemplo)./ Eu tomei algumas 
providências para proteger a nascente, plantei algumas árvores, deixei a taboa crescer e cobri a nascente. Com relação aos animais, é porque tem muita gente caçando, e pescando em épocas inadequadas.

19. Sim, o clima está mais seco, tem chovido menos e as chuvas estão mais fraquinhas.

Perdeu-se a regularidade das chuvas.

20. Sim, no regime de chuvas.

21. Diminuiu o número de bichos. / Falta de cuidados com a água.

22. Na água, chovia mais e de forma regular, hoje chove muito de uma vez só. Hoje é mais seco e o rio estreitou. O solo continua igual. Animais, tinha pouco, mas agora não tem nada. Clima, ninguém sabe a razão das mudanças climáticas, mas é claro que está ocorrendo.

23. Sim. Tem diminuído o número de animais e espécies vegetais.

24. Sim. Temos muito menos árvore e animais do que antigamente. / Devido ao desmatamento e degradação da região por ação do homem.

25. Não.

26. Sim, qualidade da água e muita perda de solo em regiões descobertas, degradação do ambiente. / Usina planta cana muito próximo do rio, contaminando a água com agrotóxicos.

27. O rio Corumbataí não passa no sítio.

28. Não.

29. Não.

30. Na temperatura: chove menos e está mais quente. Faz menos frio no inverno também.

\section{Q.8. Usa água de poço? Por que?}

1. Não. Não tenho.

2. Sim, porque o ribeirão fica longe.

3. Uso para a casa. E prefiro a do poço que a da cidade.

4. Não. Em uma das propriedades o poço foi desativado. Não sei porque.

5. Fiz 5 poços e não achei água. Usamos água tratada desde 1950. Antes ia buscar no Quebra Coco (outra propriedade da família). O rio, depois que veio a usina, não deu mais para usar.

6. Não.

7. Sim. Tem água de ótima qualidade. Levo para a cidade. Tenho bomba.

8. Sim. Pq. não tem água tratada.

9. Não.

10. Sim. Para beber.

11. Sim.

12. Sim. É melhor.

13. Este ano tive que fazer porque diminuiu a água.

14. São muitas propriedades diferentes. Cada uma com uma situação particular.

15. Sim.

16. Não.

17. Sim, porque a água é boa (poço semi-artesiano).

18. Não há poço na propriedade.

19. Sim. O local não é muito bom de água pois reduziu-se a quantidade.

20. Não. Água de mina.

21. Sim. Doméstico e horta.

22. Uso poço artesiano (18 metros de profundidade) faz 9 anos, porque não há nascente nem rio perene na propriedade.

23. Não, pois não possuo poço.

24. Sim. Porque sempre tive poço na propriedade.

25. Nada a responder.

26. Sim, apenas de poço, pois não há condição de usar a água do rio devido à quantidade de 
agrotóxico jogado nele.

27. Sim.

28. Não.

29. Não.

30. Não, porque a água da nascente é melhor.

\section{Q.9. Tem nascentes na propriedade? Como elas estão hoje (quantidade / qualidade)?} Você utiliza esta água?

1. Não.

2. Não nesta que moramos. Tem nas outras.

3. Uma nascente desapareceu por falta de chuva. Outras eu uso para lavar quintal e regar plantas. O gado bebe no rio pq não gosta da água da nascente: é muito fria.

4. Não.

5. Tem uma nascente mas não dá para usar. A água é só para a criação.

6. Não.

7. Não. Só quando chove muito (no vizinho). No tempo antigo, quando tinha mata, tinha. Agora acabou tudo.

8. Não.

9. Sim, tem vertente. A água é boa e não aumenta nem diminui.

10. É pequenininha, lá embaixo. O gado usa.

11. Sim, várias. Serve para os animais. Água de nascente é mais gostosa mas não tenho bomba.

12. Sim. A criação usa.

13. Tem uma que vem por gravidade. Protegida. Este ano quase secou porque choveu pouco.

14. São muitas propriedades diferentes. Cada uma com uma situação particular.

15. Sim. Estão boas.

16. Não. Secou. Tem uma mina.

17. Não, mas foi feito um lago para captar a água que vem da nascente do vizinho, no local onde era um brejo. A quantidade de água é a mesma sempre.

18. Sim, a nascente está produzindo mais água que antigamente. Produz água de boa qualidade. Utilizo para todas as coisas, inclusive para beber, tomando alguns cuidados (cloro, filtragem).

19. Há um pequeno córrego, mas não utilizamos a água pois fica a $14 \mathrm{~km}$ de distância.

20. Sim. Encontram-se como antigamente, com 2 metros de profundidade. Uso para beber.

21. Sim. Uso em parte, para criação.

22. A propriedade não possui nascente.

23. Não existe nascente, apenas o riacho Laranja Azeda. Não notei grandes diferenças na qualidade e quantidade de água.

24. Sim, tenho uma nascente que vira um brejo, com um pequeno açude. Não notei diferenças na qualidade e quantidade de água.

25. Sim, mas nunca foi examinada e muito menos utilizada.

26. A propriedade é fraca em água, possui poucas nascentes que não são utilizadas.

27. Sim, mas não são utilizadas.

28. Não.

29. Não.

30. Sim. A água é ótima, nunca secou. A área está cercada para não entrar gado.

Q.10. Você já plantou árvores em sua propriedade? Isoladas ou formando matas? Com que finalidade? Com espécies nativas ou exóticas? 
1. Não plantei.

2. Não plantei, só fruta. Falta tempo. Não dá para pagar empregado. Eucalipto demora muito tempo para dar dinheiro.

3. Aqui não. No outro sítio (Bairro Frio), fiz a três anos com o João do Projeto Corumbataí. Plantei também de 2 a 3 mil pés de Eucalipto para uso próprio (Contrato com a Floresp). Ocupava 0,5 alq. Roubaram e fiquei só com 100 pés.

4. Já plantei para o meu uso.

5. Achei melhor plantar alguns Eucaliptos pq cresce rápido e é lindo! Também por causa da madeira. E não tinha lei que não podia derrubar.

6. Não.

7. Não plantei. Só frutas na chacrinha.

8. Fiz o que tinha no plano de recuperação para o Rima. Mas a inundação é grande. Alagou e matou as 2000 mudas (Nativas, Ex.: Melaleuca).

9. Só planto do lado da casa. Pés de fruta. Para rebater o vento e dar sombra. Deixei algumas nativas crescerem. Agora tem muita mata. A terra ficou pouca. Gostaria de ter Eucalipto para o gasto.

10. Sim. 30 metros de eucalipto e 20 jatobás lá embaixo (próximo do rio). O Jatobá não desenvolve por causa do Eucalipto.

11. Diversas espécies de frutíferas (+- 30). Eu levo e o caseiro gosta.

12. Não plantei em mata. Só para ficar bonito e ter fruta.

13. Plantei 600 pés de Lichia. Ainda não sei no que vai dar. Foram plantadas 1800 mudas na beira do Corumbataí, mas quando o rio encheu, morreu metade.

14. Participamos do Projeto Corumbataí. É uma política da empresa perante a sociedade. Tem também o processo de qualificação (possui ISO 9000). Já plantamos entre 80 e 100 mil mudas. Plantamos Eucalipto em lugar mais acidentado. Antes era mal explorado, agora está sendo melhor conduzido.

15. Já plantei várias nativas.

16. Sim. Com o Consórcio. Toda a faixa de $50 \mathrm{~m}$. Está tudo cercado. Nem é mexido.

17. Sim, no pomar, isoladas e não isoladas, como cerca (eucalipto), arborização.

18. Já plantei, na mata ciliar algumas frutíferas e nativas.

19. Sim, formando pomares e fileiras sombreadoras utilizando espécies nativas e exóticas.

20. Sim, na beira dos tanques, formando mata, devido à exigência do IBAMA. Utilizando

espécies nativas.

21. Sim. Isolada formando corredor. Estética. Nativa.

22. Já plantei árvores isoladas na propriedade, árvores para fruta, lenha e flores.

23. Sim, áreas isoladas e com espécies nativas.

24. Sim, áreas isoladas e com espécies nativas para fazer um corredor para ficar mais bonito.

25. Não.

26. Não, tudo que a propriedade possui é regeneração natural.

27. Não.

28. Já foram plantadas árvores para a recuperação da mata com espécies nativas.

29. A prefeitura plantou por duas vezes, mas por falta de cuidado as árvores não foram para frente.

30. Não.

\section{Q.11. Plantaria (outras, caso já tenha plantado)? Por quê, para quê e de que tipo?}

1. Não Plantaria. A propriedade é muito pequena.

2. Só plantei frutífera.

3. Plantaria sim.

4. Plantaria. 
5. Sim. Para ficar bonito.

6. Não sei.

7. Só frutíferas.

8. Já plantei tudo que pediram.

9. Não tem mais espaço.

10. Eu gosto de árvore em volta da casa.

11. Plantaria mais. E queria saber mais sobre o programa de ajuda.

12. Plantaria onde não tem cana. Estou para plantar na beira do rio e outros lugares.

13. Plantaria se fosse obrigado e se desse mais dinheiro. E faria cercas vivas.

14. Estamos sempre plantando mais. Temos acordos e o processo de certificação.

15. Não sei.

16. Não plantaria mais.

17. Sim, plantaria espécies nativas para utilizar a área para o ecoturismo.

18. Plantaria, pois gosto muito de árvores. Para alimentação, sombra, proteção do solo, etc.

19. Não, pois tem que haver muita responsabilidade, que o capinzal da usina fica próximo e apresenta alto risco de fogo.

20. Sim. Na beira do rio e dos tanques.

21. Sim. Nativas e frutíferas.

22. Plantaria outras (já tenho até mudas), pois considero árvore importante, gosto de flor e frutos. Plantaria Ipê, frutíferas e eucalipto e só não planto mais árvores porque o solo é ruim. 23. Sim, com o objetivo de preservação das espécies vegetais, dos animais e para melhorar o ambiente.

24. Plantaria, mas por enquanto não tenho interesse.

25. Não plantamos árvores, existe a plantação de cana.

26. Sim, plantaria jacarandá, cabreúva, peroba, para que um dia elas tenham algum tipo de utilização.

27. Sim, madeira de lei para utilização.

28. Plantaria para preservar a Natureza e os animais.

29. Plantaria, mas não tenho condições nem interesse.

30. Sim, eucalipto para vender.

Q.12. O que o levaria a não plantar árvores na propriedade? (espaço, dinheiro, mão de obra, etc.).

1. Plantaria árvore nativas na propriedade.

2. Falta de tempo e sombra na lavoura.

3. Nada. Deveria plantar mais frutíferas. Para a favela comer e não roubar da gente.

4. Falta de tempo.

5. Eu sou muito velho. Não agüento mais.

6. O descaso do Florestal. (Todos os marginais põem fogo e a polícia não faz nada).

7. Não trabalho mais. Já fiz a minha parte. Se quiserem fazer, eu deixo.

8. Área encharcada faz morrer muda.

9. Tem pouco espaço. Já tem bastante terra com capoeira.

10. Não. Por falta de espaço. Mas vou deixar as frutíferas que minha mãe plantou. Onde tem cana só atrapalha.

11. Tenho plano de plantar mais: frutíferas e para ficar bonito e fazer sombra. Mas quero saber o que plantar para formar mata onde tá molhado.

12. Nada.

13. Nada. Mas não posso plantar muito porque senão fico sem terreno para continuar

produzindo (Milho, ....). 
14. Nada.

15. Falta de espaço.

16. Não tem mais espaço.

17. Dificuldade para conseguir mudas ou sementes. Não plantaria eucalipto, pois é preciso plantar em um local apropriado, porque um dia sempre é preciso cortar o eucalipto.

18. Não planto mais árvores por causa do gado que come ou pisa na muda. O custo do plantio fica muito alto, se eu quiser cercar a área para proteger dos animais.

19. Há grande responsabilidade sobre o plantio. Muito trabalho.

20. Falta de dinheiro.

21. Nada.

22. A qualidade do solo impede de plantar mais árvores na propriedade. Não tem árvore que se adapte.

23. Não, pois poderia faltar incentivo e tudo acabar em nada.

24. A falta de dinheiro e grandes necessidades.

25. Mão-de-obra e dinheiro.

26. Mão-de-obra, escassez de mudas, etc..

27. Mão-de-obra, mudas, etc..

28. Nada.

29. Dinheiro e mão de obra.

30. Não plantaria se fosse numa área não adequada.

\section{Q. 13. Qual a importância que as árvores isoladas têm para o senhor?}

1. (Esta pergunta foi acrescentada depois da realização dos 8 primeiros questionários).

2.

3.

4.

5.

6.

7.

8.

9. Tenho duas árvores de jardim: Marfim e Quina. Servem para rebater o vento e dar sombra. 10. Tenho estima pelas árvores. Jatobá é muito bonita. Tem as que rebate o vento. As para sombra. As de fruta. E é bom para o ar.

11. Gosto de sombra e verde.

12. Sombra. É tão gostoso a árvore, o cheiro dela. Beleza. Árvore tem uma mais bonita que a outra. Como flor. Muitas ainda são frutíferas.

13. Não tem utilidade pois não é madeira de lei. Mas dá sombra. Beleza (palmeira).

14. É até ridículo.

15. São importantes para preservar espécies que já não tem mais no campo.

16. O povo diz que atrapalha o pasto.

17. Todas as árvores são importantes, independente de estarem isoladas ou na mata.

18. Todas as árvores são importantes, porque árvore é vida, é alimento. Aquelas que ficam isoladas têm menor importância do que as que estão na mata.

19. Sombra, frutos, beleza.

20. Sombra.

21. Sombra, beleza, refresca o ambiente, pássaros e frutas.

22. Valorizo a beleza, sombra, flores e frutos das árvores presentes na propriedade.

23. Deixa mais bonito e serve para os pássaros criarem seus ninhos.

24. Para mim nenhuma. É boa só para os pássaros. 
25. Isso é muito importante, pois seria de uma grande valia para o nosso ar.

26. É sempre bom ter, né?!

27. Goste de tê-las.

28. Tem árvores que tem muitos anos, plantadas pela família, que atraem os pássaros.

29. Nenhuma.

30. Eu gosto das frutíferas.

Q.14. Sua propriedade apresenta problema de erosão? Como é esta área? 1. Não.

2. Não.

3. Não. Tá tudo feito terraço.

4. Não, uso curva de nível.

5. Alguma coisa.

6. Não.

7. Não.

8. Na parte de cima. Devido ao asfalto. Perto do rio não.

9. Sim. Tenho que fazer curva uma perto da outra.

10. Não. Tento segurar com curva de nível. Tem mais caída porque é estreita.

11. Sim. Agora tá controlado. Já tinha curvas e mantemos.

12. Sim. A área tá abandonada. Não tem preparo e máquina para fazer curva de nível e para pagar não dá.

13. Não, porque o terreno é argiloso. Só tem erosão na estrada, por culpa da prefeitura que vem e joga a água na propriedade da gente.

14. A erosão é tratada e os fornecedores de cana são orientados.

15. Não.

16. Não. Já foi controlada.

17. Não, porque tomei os devidos cuidados.

18. O problema de erosão está localizado na cerca, na divisa com o vizinho que planta cana-deaçúcar. É uma parte do solo que fica descoberta, então quando chove forma sulcos. Mas nunca se torna um grande problema, porque ele sempre reforma a área para o plantio.

19. Não. Há acessoria técnica por parte da usina.

20. Não, pois o solo é firme.

21. Sim.

22. Possui erosão, mas pouca. Não apresenta voçoroca.

23. Não.

24. Não.

25. Não apresenta problema de erosão pois é uma área pequena de 8 alqueires.

26. Não possui.

27. Não.

28. Já teve problema, mas não tem mais.

29. Não apresenta problemas de erosão.

30. Quando aparece, eu faço curva de nível.

\footnotetext{
Q.15. Sua propriedade possui faixas de floresta ao longo dos rios? Por que? Qual a metragem?

1. Deixei 30 metros sem mexer. Já surgiram algumas árvores. Devido à obrigação legal.

2. Tem perto das nascentes e do rio, que a gente deixa reflorestar sozinho.

3. Estou plantando. Mais ou menos 5 metros.
} 
4. Só no sítio São Pedro. Tem um córrego que deságua no Corumbataí. Tem 36 ha no total e 4 ha de mata na baixada.

5. Tem beirada de mata, mas é pouca.

6. Não.

7. 50 metros.

8. 0,2 ha não tem cobertura devido a autorização do IBAMA, para estocagem de areia.

9. Sim. Até 10 metros. Alguns lugares tem mais outros ficam sem árvores. Se plantar árvore em toda beira, não esquenta água para o gado.

10. Ficou a barranca com eucaliptos (plantados há 38 anos) e arvorezinhas que saíram no meio (Jatobá tem 2 anos). Se derrubar eucalipto, esmaga as pequenas.

11. Não passa o rio mas tem nascentes que deságuam no rio. Tem área grande sem usar. Só o gado anda.

12. +- 50 metros. Deixei de usar mas não plantei ainda.

13. Plantei e deixei.

14. São muitas propriedades diferentes. Cada uma com uma situação particular.

15. Sim. O rio é uma beleza.

16. Sim. Porque fiz acordo com o Consórcio.

17. Sim, mas é no máximo 15 metros de largura.

18. Sim, pois já havia mata nativa no local. Não sei dizer a metragem correta, mas existe área com mais de 100 metros (mais ou menos, estimado).

19. Sim. Não se sabe se é o ideal. Deve haver uns 15 a $20 \mathrm{~m}$ de floresta. A área está abandonada e apresenta bastante capim.

20. Sim, o que precisa.

21. Sim, de acordo com a lei.

22. A propriedade não possui rio.

23. Não, apenas algumas capoeiras com bastante falhas.

24. Não possui vegetação.

25. Não possui.

26. Possui cerca de $1 \mathrm{~km}$ de mata nativa, oriunda de regeneração natural.

27. O rio não passa nessa propriedade.

28. Possui faixas quase recuperadas.

29. Não.

30. Sim, mas com poucos metros.

Q.16. Você se sente prejudicado por algum dano ao meio ambiente praticado em alguma propriedade próxima (vizinho)? O que você acha que deveria ser feito a este respeito?

1. Não.

2. Não.

3. Sempre aparece cavalo solto. Fogo sossegou.

4. O grande problema da região é a utilização de agrotóxicos. Seca a terra. Todos usam. Ainda que o "Roud Up" não faz isto (não estraga muito a terra).

5. Não.

6. Não.

7. Não.

8. A usina joga agrotóxico.

9. Não. Quando a usina passa veneno para amadurecer a cana, mata mamão. Quando soltou restilo, estourou a curva de nível e espalhou pela terra. Matou gado que bebeu água do rio com restilo.

10. Não.

11. Não. Todos preservam porque todos tem dificuldade com água para o gado. 
12. Eles acabaram com tudo. Todas as matas. Secaram até o brejo. Afeta até as águas para cima. As nascentes sentem.

13. Não. Na cidade sim.

14. Não.

15. Não.

16. O vizinho não quer nem saber de plantar. Para ele não interessa pois beneficia só os que estão rio abaixo.

17. Não.

18. Não.

19. Apesar de hoje em dia ter melhorado bastante a usina ainda joga bastante tranqueira no rio.

20. Sim, pois o tanque de restilo da usina causa cheiro ruim.

21. Não.

22. Não há problemas com o vizinho, a turma sabe trabalhar. Existe cooperativa que possui acordos para cuidados a serem adotados em relação ao fogo. É importante a fiscalização. 23. Sim, o vizinho não muda para contribuir com a melhoria do rio. Poderia implantar mais espécies na mata ciliar.

24. Por enquanto não.

25. Não.

26. Não.

27. Não.

28. Não, mas o rio já teve mais água.

29. Não.

30. Agrotóxicos usados nos vizinhos poluem a água.

\section{Q.17. É bom estar numa bacia de abastecimento de água para Piracicaba? Por que?}

1. Deve-se cuidar para ter água.

2.Não deve ter moradia perto do rio. Não ajuda do jeito que tá, estão exigindo muito. A água é boa mas a faixa é demais. Deveria começar com 5 metros, depois ir aumentando.

3. Estou contente pq a água (do Corumbataí) limpou muito. Mas a prefeitura colocou esgoto dentro do pasto do Mantelato. Entra no Piracicaba.

4. Sim, pelo valor que tem a água hoje.

5. É bom. A água é boa. O povo também merece água boa.

6. Sim.

7. É bom pq propriedade sem rio perto não tem valor. É um dom da Natureza. Coisa mais linda!

8. É bom. Evita de poluir o rio.

9. Gosto. Porque a água será mais pura.

10. A faixa já é pequena. O rio não atrapalha nada.

11. Bom, ótimo. Fica mais respeitado.

12. Mais para ruim do que para bom. Dá medo de causar um dano e a lei vir para cima e não ter como se defender. Se alguém tocar fogo próximo a gente é que paga. Antes davam valor a água no sítio. Hoje ninguém mais quer.

13. É ruim. Tenho porto de areia e toda hora vem fiscalização. A Sedeplama e a polícia florestal não dão sossego. Ficam em cima. Fiz 5 lagoas, agora não faço mais.

14. Estamos aí. Não ajuda nem atrapalha.

15. Sim. O rio fica mais limpo.

16. Sim.

17. Não faz diferença, a responsabilidade de cuidar da água é de todos.

18. É bom, mas é uma grande responsabilidade, porque o que fazemos no rio será feito para a água que vamos beber na cidade.

19. Sim, mas estou bastante preocupado com a diminuição da vazão do rio. 
20. É ruim porque a cidade suja o rio. As pessoas da cidade falam que quem está prejudicando o rio são as pessoas do sítio, mas quem está prejudicando, na verdade, são as pessoas da cidade.

21. Não respondeu.

22. Acho indiferente pois estou longe ( a $2 \mathrm{~km}$ ) do rio.

23. Bom porque a água é vida.

24. Não faz muita diferença.

25. Seria bom, mas nosso sítio é muito pequeno.

26. Sim, pela importância da bacia.

27. O rio não passa nessa propriedade.

28. É bom ter uma propriedade próxima ao rio.

29. Não faz diferença para mim.

30. Não. Puxam a água e o rio diminui o nível.

Q.18. O que você sonha para a sua propriedade no futuro (2, 10 e 30 anos)?

1. Nada. Apenas a mantenho para ter convênio médico com o hospital dos plantadores de cana.

2. Sonho fazer tanque pesqueiro. Para ter mais dinheiro e para as pessoas poderem usar.

3. Vender. E reservar apenas uma chácara para morar.

4. Acabar com a monocultura. Manter a consciência ecológica.

5. Não tenho sonho na minha idade.

6. Plantar girassol ou mamona.

7. Estou sempre melhorando. Construindo, arrumando.

8. Não tenho sonho para o futuro.

9. Gostava de ter uma fazenda para ter gado e ter de tudo. Tenho dívidas, aí não dá.

10. Ta difícil. Não tenho nenhum sonho. Ninguém mora mais aqui. Estamos muito sozinhos.

11. Ideal para criar peixe e abelha. Gosto de bicho e de árvore. Quero represinha para lazer.

12. Não tenho sonho. Com estes governos nossos não há quem mude. Depois que veio a democracia, piorou. Os militares eram melhores. Tinha lei que ajudava a turma do campo. E a lei parecia que funcionava. Hoje só fala, fala. Antes podia comprar alguma coisa. Não tinha juros, era fixo.

13. Vender.

14. Maior planejamento. Plantar Cana e Eucalipto e adaptar as condições de acordo com o solo e a inclinação, para cada cultura.

15. Poder vir mais.

16. Não sei.

17. Gostaria de fazer da minha propriedade uma área verde, que, no futuro pudesse ser

utilizada para ecoturismo, e tivesse valor econômico.

18. Eu quero continuar utilizando-a para lazer em fins de semana, férias, etc.

19. Paz e tranquilidade, mas acredito que inevitavelmente haverá mudança para a cidade.

20. Aposentar e ficar no local.

21. É provável a venda, mas se não for plantar, criar gado.

22. Não possuo muitos sonhos. O crescimento da cidade trás a possibilidade de venda para loteamento para chácara.

23. Cultivar lavouras, mas não com a cana-de-açúcar.

24. Ampliar minha área de implantação.

25. Se estivesse em nosso alcance, gostaríamos de morar em uma chácara, para poder aproveitar, fazer uma área de lazer e ter muitas árvores frutíferas plantadas e mais coisas do gênero.

26. Não tenho sonhos, provavelmente a minha propriedade será vendida.

27. Eu não tenho sonhos e essa propriedade irá para inventário para ser vendida. 
28. Nada em especial.

29. Nada, desejo continuar plantando cana.

30. Criar peixe.

\section{Q.19. Na sua opinião, para que servem as florestas e as matas?}

1. Para evitar erosão.

2. É bom para tudo.

3. Se for bem conservada, para madeira de lei não serve mais. Hoje, para manter os mananciais. Fauna e flora também.

4. Sempre é bom pro ambiente.

5. É uma boniteza.

6. Para o bem do clima em geral.

7. Para conservar o solo e a natureza. Dá outro ar, outra vida. Sem calor.

8. Para conservar os rios, evitar erosão, evita levar sujeira para dentro do rio.

9. Para conservar, tanto o solo como as águas. O mato puxa umidade, conserva as vertentes.

10. Pro próprio meio ambiente. O oxigênio.

11. Para dar frutas, sombra e embelezar.

12. Influi em tudo. Serve mais para criar passarinhos, bichos. O que será do mundo sem uma borboleta? Nada. Muita planta e passarinho é bom porque controla muita coisa. Formiga, se Deus fez, alguma utilidade tem. E se acabar mata, acaba tudo isto. Café e laranja até que não, mas lavoura mecânica acaba com tudo.

13. Para proteger o solo, as nascentes.

14. Preservação. A usina já tem uma parceria com a prefeitura.

15. É bom para preservar espécies.

16. Serve para a lei.

17. Proteção do solo e da fauna.

18. Servem para a produção de alimento, controle de pragas, conservação do solo, abrigo dos animais, etc.

19. Segura a umidade e regula as chuvas, além disso evita voçorocas na beira do rio e fornece matéria orgânica para o solo.

20. Ajudam as nascentes de água.

21. Equilíbrio do meio ambiente, preservação da fauna e ecossistema. O homem não sabe disso.

22. A mata é necessária assim como tudo que Deus criou. A própria vida exige um meio de viver, e o homem não consegue viver na mata, então é preciso desmatar.

23. Protege a fauna, protege a vida.

24. Bom porque abriga muitas espécies.

25. Para purificar o ar. Nos dar ar mais puro é uma maravilha!

26. Serve para a proteção de rios, abrigo de animais e se todos que tivessem uma pequena

florestas preservassem, não iria faltar árvores mesmo para uso pessoal.

27. Proteção da Natureza.

28. Atraem os pássaros e protegem a margem do rio.

29. Acho importante, mas não sei porque.

30. Para manter a oxigenação da terra.

\section{Q.20. Elas (florestas e matas) devem ser protegidas? Por que?}

1. Sim. Porque todos precisam dela.

2. Sim. Pode deixar se não avançar na lavoura. Mas tem que deixar cortar galhos para não fazer sombra na lavoura. Sombra é sempre ruim. 
3. Sim. Deve-se proteger nativas da região para os nossos filhos saberem o que é. E para melhorar o clima.

4. Sim. Mais por causa da fauna.

5. Sim. Para conservar a boniteza.

6. Sim. Pelo clima.

7. Sim. Não acredito que tudo tenha sido destruído!

8. Sim. Porque se continuar como está, meus filhos não vão ver, como eu não vejo Pau-Brasil por aí. Deve-se preservar e reflorestar as áreas devastadas.

9. Sim. Quanto mais puder. Para conservar tudo. Tendo mato no terreno de cima, o mato segura toda a terra e não desbarranca.

10. Sim.

11. Sim.

12. Sim. E se possível, plantando mais um pouco.

13. Sim. Porque se não, seca as nascentes. $\mathrm{E}$ tem que ter árvores para sombra.

14. Sim, não há dúvida. Para preservação.

15. Sim.

16. Sim, mas deve dar um retorno para o proprietário.

17. Sim, porque são importantes para o meio ambiente.

18. Sim, pois a nossa vida depende da existência dessas matas.

19. Sim. $40 \%$ de cada estado deveria estar preservado.

20. Sim. Bastante e por todo mundo.

21. Sim, devido a proteção dos rios, do ecossistema e equilíbrio do meio ambiente.

22. As florestas devem ser protegidas por leis, pois mesmo com elas o pessoal destrói. Sem leis tudo seria destruído.

23. Sim, por causa da vida que necessita dela.

24. Sim, pois temos muito pouco de matas.

25. As florestas têm que ser protegidas, mas existem outras pessoas que acabam com isso.

26. Sim, principalmente na beira dos rios.

27. Sim.

28. Sim.

29. Sim, pela Natureza, os animais e a água.

30. Sim, porque são fontes de recursos.

\section{Q.21. Qual é o tipo de vegetação que deve ser protegido e qual o tipo que pode ser derrubado? Por que?}

1. Devem ser protegidas as matas que evitam erosão e derrubadas as árvores mortas.

2. Deveria poder cortar as árvores sem qualidade no meio da lavoura para deixar mais livre. Se tiver árvore no meio, fica ruim queimar a cana. Deveria proteger as árvores boas (nativa, com frutas).

3. Deve proteger as nativas e derrubar a Garra-garra (Arranha-Gato). Atrapalha a cana.

4. Eucalipto pode ser derrubado. Corta e renova.

5. Eucalipto para cerca (pode ser derrubado). E conforme precisar. Deve proteger as árvores boas.

6. Deve proteger mata nativa e derrubar Eucalipto.

7. Todo tipo deve ser protegido (Guarantã, Cabreúva, etc.). Eucalipto pode ser derrubado.

8. Todas devem ser protegidas. Desde o Pau-Brasil. Deve derrubar Cana e coisas para uso. Eucalipto, se fosse meu, não derrubava.

9. A madeira de Lei deve ser conservada. Aquelas com carne e força. Árvore à toa pode ser derrubada. Deve plantar árvore de futuro. Sangue d'água fica 4 ou 5 anos e já seca. São sem qualidade. Não agüenta. Não deve também, plantar eucalipto na beira d'água, ele chupa a 
umidade.

10. Na região existe um tipo de árvore que não vale nada. Tipo tiririca. Santa Bárbara. Cedrinho. Não deve eliminar, mas estas árvores tem que ficar no lugar delas.

11. Não pode derrubar quase nada. Só o que precisa.

12. Deve proteger mais as árvores frutíferas porque é bom para o homem e para a Natureza.

Não deve derrubar nenhuma, só o Eucalipto que foi plantado para este fim.

13.Todas devem ser protegidas. Mas derrubei uma com espinho grande que cai no chão e a vaca pisa e faz mal.

14. Devem ser protegidas as nativas e as em área de preservação. Não tem área que possa ser derrubada, a não ser plantio de Eucalipto.

15. Deve proteger todas as árvores.

16. Deve proteger aquela que não atrapalha.

17. As matas nativas devem ser protegidas, as florestas de eucalipto que são de empresas podem ser derrubadas.

18. Toda a vegetação deve ser protegida, exceto as monoculturas. Sou totalmente contra a monocultura (de alimentos e também de eucalipto). Mas mesmo assim, eu acho uma judiação queimar as florestas de eucalipto.

19. Não sei.

20. Eucalipto seca a água da nascente e as outras não.

21. As nativas. Equilíbrio natural.

22. Deve proteger em volta das nascentes e cursos d'águas, pois o vento seca as nascentes e as árvores protegem as nascentes do vento. Deve ser explorada, de acordo com a necessidade do ser humano. Porque o homem em primeiro lugar.

23. Deve-se proteger tudo, quanto menos mexer é melhor.

24. Deve-se proteger tudo, principalmente as beiras dos rios.

25. Sim, toda vegetação deve ser protegida, seria de bom agrado poder proteger todos sem derrubá-los.

26. Devem ser protegidas as árvores localizadas nas beiras dos rios, evitando

desbarrancamento. Devem ser derrubadas árvores para uso doméstico, em caso de extrema necessidade.

27. Sim. Derrubar só quando precisar.

28. Tem que proteger, mas para produzir tem que derrubar parte da mata.

29. As beiras dos rios devem ser protegidas.

30. Deve-se proteger as nativas porque equilibram o meio ambiente e derrubar as de pequeno

porte, de campo e cerrado, porque a derrubada não prejudica o meio ambiente.

\section{Q.22. Você acha que a mata ciliar realmente protege os cursos d'água? Como?}

1. Não sei.

2. Só um pouquinho, uns 10 metros já dava. 30 metros é muito e ainda ela faz sombra e a gente perde mais terra.

3. Sim. Evita erosão e mantém a umidade lá embaixo. Pela constituição, é garantido o acesso a água. O proprietário paga imposto até a beira. Teriam que desapropriar e indenizar para não deixar usar a área.

4. A mata ciliar preserva a água pois evita erosão. Na fronteira da minha propriedade não tem mata. Fizeram porto de areia.

5. É bom ter árvores na beira do rio. Mas o pessoal taca fogo.

6. Sim.

7. Sim. Capim segura a terra.

8. Protege. Mas na minha propriedade, a falta de mata não prejudica o rio.

9. Sim.

10. Fica bonito. Mas se deixar de chover, não adianta árvore para ter as nascentes vivas. 
Dependendo do tipo de árvore, puxa a água ou não.

11. Sim. Sombra atrai passarinho e um monte de coisa boa.

12. Não sei. Protege os peixes. Eu acho bonito e serve pros peixes.

13. A água não. Mas protege o barranco, contra a erosão. E goiaba é alimento para peixe.

14. Protege.

15. Sim.

16. Sim, mas não o rio da minha propriedade. Só das que vem abaixo.

17. Sim, porque o solo fica protegido contra erosão.

18. Sim, porque protege o solo da erosão.

19. Claro. Segura a terra para não invadir o rio e protege a água.

20. Sim, segura a erosão.

21. Sim, árvores retém umidade.

22. Sim, pois as árvores protegem as nascentes e rios do vento e do sol, que as secam.

23. Protege, mas tem que deixar do tamanho adequado para impedir a poluição.

24. Sim, pois protege da agricultura e dos produtos químico.

25. Sim, todos os donos de sítios, fazendas, deveriam ter uma mata ciliar.

26. Sim, segurando os barrancos.

27. Sim.

28. Sim. Evita a erosão.

29. Sim, ela protege os cursos d'água porque a atividade agrícola na margem do rio o destrói.

30. Sim.

\section{Q.23. Você acredita que a fauna silvestre deve ser protegida? Por que?}

1. Sim. Pelo meio ambiente.

2. Sim. Capivara. Mas deve proteger só se não der problema na lavoura.

3. Sim, mas com controle da Capivara.

4. Sim. Principalmente os passarinhos. Antes a criançada matava. Hoje não mata mais.

5. Animal aparece. Tem mais passarinho agora por causa da fiscalização. Diminuiu a caça.

6. Sim.

7. Sim.

8. Sim.

9. Sim. Aqui não existia muita variedade de pássaro. Comprei passarinho azulão e soltei. $O$ pessoal caçou tudo. A usina, com a queimada, acabou com passarinhos. Eu só mato bicho que dá prejuízo: gato do mato, cachorro do mato, raposa.

10. Principalmente os pássaros. Levam para longe as sementes.

11. Sim. É bonito e necessário.

12. É lógico.

13. Deve. Mas gato atrapalha (eu mato) e capivara não é bom. Tem que soltar rojão para espantar pomba do milho. Jacaré eu tiro das lagoas e jogo no rio.

14. Sim.

15. Sim.

16. Passarinho sim.

17. Sim, porque é importante. Mas quase não há caça!

18. Sim, porque eles fazem parte do ecossistema.

19. Sim, porque aonde tem mais bicho tem mais controle de pragas. Em 100 ha com árvores há menos pragas que em 100 ha sem árvores.

20. Sim, mas podia liberar para caça de vez em quando.

21. Sim, equilibra o ecossistema e embeleza.

22. Sim, pois são viventes e bonito de se ver, porém a necessidade do homem em primeiro 
lugar.

23. Sim, porque se não existe flora e fauna, tudo vira um deserto.

24. Sim, porque existe muito pouco animal e algumas árvores estão sumindo.

25. Sim, daria outra vida, e todos os grandes fazendeiros deveriam ter uma área separada só para isso.

26. Sim, pois existem animais que estão sumindo.

27. Sim.

28. Sim. Pela sua beleza.

29. Sim. Pela beleza dos passarinhos.

30. Sim, desde que não prejudique as culturas.

\section{Q.24. O que você acha das pessoas que põe fogo proposital na floresta ou mata, ou derrubam árvores que devem ser preservadas? Elas devem ser punidas?}

1. Não. Deve conscientizar.

2. Se colocar fogo antes da safra por maldade, deve punir. Mas se for acidente, não. A lei dirá como.

3. Na região da cana, o proprietário não põe fogo na área de preservação. Só criminosos. Estas pessoas não só devem ser punidas, mas seria bom se o proprietário pudesse agir.

4. Idiotas. Devem ser punidas com certeza. Menos em caso de acidente.

5. Deve ter uma lei para isto. Mas, se precisa de madeira, seria bom poder cortar na beira do rio. No rio deveria dar árvore em galeiro.

6. Na maioria das vezes, sim.

7. Malandragem. Devem ser punidas (Multas).

8. Cadeia neles!

9. Cadeia perpétua! Quem põe fogo em cana fora do tempo também deveria pegar cadeia.

10. Acho que é errado. Não deve fazer estas coisas. Mas se for proposital é uma coisa, se não for é outra. Para punir tem que ver estas questões.

11. Sim, devem ser punidas.

12. Teria que Ter uma lei severa para punir eles e fazer pagar. Hoje, fica por isto mesmo. Quem tem dinheiro manda. Deveriam ser presos e multados.

13. Toda hora aparece. Geralmente pescador que põe fogo brincando. Não consigo pegar.

14. Antes da punição deveria ter orientação. Principalmente para quem utiliza queima onde é proibido. Estamos cortando crua próximo ao perímetro urbano, estrada ou reserva.

15. Sim. Deve punir.

16. Deve ser punido.

17. Sempre existirão pessoas desse tipo, mas não há como punir, pois ninguém vê o fogo começar e pode ser acidental.

18. Sim, mas é necessário fiscalização.

19. São uns loucos, devem ser queimados devagarinho.

20. Uso o fogo para limpar a cana, mas às vezes escapa para a mata, mas nunca fui punido.

21. Sim, merece punição, é uma atitude criminosa e irracional.

22. As pessoas que põe fogo na mata não devem ser punidas, mas orientadas/instruídas. A fiscalização governamental é necessária.

23. Por ignorância, tudo isso deve ser protegido.

24. Porque querem mais espaço para plantar. Elas devem receber multas por isso.

25. Naturalmente isso é um crime e o governo deveria agir com mais rigor, nesses acontecimentos.

26. São bandidos, devem ser punidos, inclusive as pessoas mais poderosas, como os donos de usina.

27. Devem ser punidos. 
28. Não deve botar fogo.

29. Não posso recuperar, mas o que sei é que não posso queimar. É lei agora. Porém, não sei se deve-se punir.

30. São criminosas, devem ir para a cadeia.

Q.25. Você sabe que existem leis que cuidam das matas? O que você pensa sobre estas leis (são boas, ruins, têm sido obedecidas,...)?

1. Sim. Mas não conheço bem o conteúdo.

2. Conheço alguma coisa. Acho 30 metros muito para um córrego de 2 metros. 10 ou 15 metros tava bom. Até 20. Se não, acaba a lavoura, faz sombra. E acho que deveria punir todos igualmente. A polícia deveria tratar todos igual. Tem muita lei que deixa com medo. Prejudica e desanima quem já nem tem muito ganho.

3. Sim. Acho que a lei não é ruim, mas o pessoal da florestal abusa da farda. Até prenderam o meu filho.

4. Sei que existe mas não sei o conteúdo.

5. Não conheço as leis. Sei que passa fiscal mas nunca me multou.

6. Sim. As leis existem mas nem sempre são cumpridas.

7. Sim. Só por cima.

8. Soube pelo Rima. São boas, e falta mais.

9. Não.

10. Sim. Mas não conheço corretamente.

11. Sim. Tem coisa que é boa e coisa que é ruim. Brejo, não pode fazer valeta, melhoramento. É difícil conseguir autorização para fazer represa.

12. Sim. / Conheço um pouco. São boas. Não exige nada mais do que deveria ser. A usina está cortando Eucalipto e derruba outras árvores. Só não corto o que está na beira da estrada. 13. Sim. E como! (Esposa). / Deve ter leis mas tem que existir o bom senso. Hoje não tem conversa. Primeiro faz multa, não fala como deveria ser. Não se pode cortar um fio de capim sem autorização. Como a pessoa vai saber? A promotora fala um monte. Xinga. Já tenho uma condenação. Não posso sair por dois anos. Os sem-terra estão destruindo tudo e não fazem nada. O governo manda coisa para eles e eles não usam. Recebem tudo do gov., então, por que plantar?

14. Sim. Temos acessoria. Damos orientação e conscientizamos funcionários e fornecedores. Tem que estar sempre conscientizando.

15. Sim, mas não conheço bem.

16. Sim. São severas.

17. Sim. Tenho pouco conhecimento sobre o assunto.

18. Sim. As leis são boas, mas as pessoas não conhecem as leis e não há divulgação e nem fiscalização.

19. Sim. Tem que ter uma linha dura senão o mundo acaba indo para o inferno. Deve haver multas e deve ser verificado direitinho tudo o que está acontecendo. Multas muito altas são impossíveis de se pagar e colocam o agricultor na marginalidade.

20. Sim. Não dão andamento às prioridades e quem tem dinheiro consegue fazer rápido.

21. Sim. São boas mas podem ser aprimoradas, não têm sido obedecidas.

22. Sim. Não faltam leis, a lei está certa, mas deve Ter mais fiscalização e orientação. A

fiscalização não deve ser radical (bruta/impositora). Deve haver mais orientação pois a lei não é clara.

23. Sim. São ruins na execução.

24. Sim. São pouco obedecidas, pois são muito ruins para o proprietário.

25. Sim. Deveriam ser melhor utilizadas e corrigir os erros nas leis.

26. Sim. Mas as leis devem existir para todos, não só para alguns. Os pequenos produtores estão sendo muito prejudicados (punidos com multa) por causas injustas. 
27. Sim, mas não sei o que dizem.

28. Sim. São boas, mas não as conheço muito bem.

29. Sim. Seria bom produzir nas margens, mas lei é lei.

30. Sim. Elas não tem sido obedecida, muito pouco.

\section{Q.26. Você conhece o Código Florestal Brasileiro? Você o acha adequado? Qual o artigo que Ihe chama mais atenção? \\ 1. Não. \\ 2. Não. \\ 3. Alguma coisa. Li e adquiri conhecimentos no curso de Administração. Acho que no perímetro urbano a APP é de 10 metros. A lei a gente respeita, mas tem que ter flexibilidade. Tomei multa por causa de 2 metros. Também não sou obrigado a ler jornal ou Diário Oficial.}

4. Só sei que existe.

5. Não.

6. Alguma coisa.

7. Ouvi falarem. Deveria ser mais rigoroso.

8. Ouvi falar e compreendi algumas coisas. Acho que para cada caso é um caso. Tem que ver quem tá prejudicando. E tem lugares que já tava desmatado.

9. Não.

10. Não. / Não é exagerado.

11. Não.

12. Não.

13. Sim. Acho bom, mas tem que ter um pouco de tolerância.

14. Sim. Estão fazendo revisão. Queria saber o porquê de 100, 50, $30 \mathrm{~m}$ em torno do rio. E sobre o tamanho da reserva florestal.

15. Sim, por cima.

16. Sim.

17. Muito pouco. Nunca tive interesse em conhecer.

18. Não.

19. Ouvi falar mas não conheço o conteúdo.

20. Não.

21. Sim.

22. Não.

23. Não.

24. Não.

25. Sim. Precisa modificar o Código Florestal.

26. Sim, mas tenho pouca informação sobre ele. Acho que seria muito importante recebermos orientações antes de sermos punidos com multa.

27. Sim.

28. Sei de sua existência.

29. Não.

30. Alguma coisa. Acho exagerada. $3 \mathrm{~m}$ na beira do rio estava bom.

\section{Q.27. O que você acha que deve ser feito para que as leis florestais sejam cumpridas?}

1. Deve ser feita vistoria.

2. As leis devem ser cumpridas por todos, grandes e pequenos. Quem está em cima (cabeceira) e quem está embaixo. Deve ir reflorestando gradativamente, 10 metros e depois ir aumentando. Deve ensinar leis sem prejudicar os trabalhadores. Ensinar técnicas de proteção sem punir. 
3. O proprietário deveria poder efetuar prisão em flagrante. De forma controlada.

4. Deveria divulgar mais a lei. A imprensa. Não dá para punir se o cara não conhece.

5. Deve ter leis, mas plantar na minha propriedade é tempo perdido. Os vândalos põe fogo. Mas deve ter disciplina do jeito que as coisas estão!

6. A polícia florestal tem que parar de corrigir os pequenos infratores, e prender os grandes.

7. Os homens de lá de cima que devem saber.

8. Tenho que ter toda a documentação em ordem. Acho que todos devem seguir o meu exemplo. Florestal interdita outros portos, mas o pessoal volta quando o IBAMA distrai.

9. Deveria ter lei que protege, a não ser se for a maioria mata e precisar plantar, daí poderia tirar um pouco. A lei deveria ser severa. Se não der pena dura para o sujeito, eles vão continuando. Multa não pagam.

10. A gente não pode questionar isto de forma nenhuma.

11. Deve aumentar fiscalização.

12. Sei lá, não sei.

13. Acho que estão cumprindo até demais. Deve fazer revisão e corrigir algumas coisas. Tenho um terreno perto da cidade para lotear e de 12 alqueires, vou perder 8 porque passa um fio d'água. Não acho isto justo.

14. A polícia florestal atualmente só vem punir. Não orienta. Há diferenciação para determinados grupos (corrupção). Tem comportamento diferente com certos proprietários. É muito mais fácil punir usina.

15. Fiscalizar.

16. Deve dar um incentivo em dinheiro para as pessoas plantarem.

17. Acho que as leis ambientais são mais cumpridas do que as leis civis.

18. É necessário que os policiais florestais tenham condições dignas para fiscalizar.

19. Fiscalização honesta e principalmente esclarecer antes de multar.

20. A lei demora tanto que algumas obras são feitas sem autorização de órgãos competentes e quem acaba sendo prejudicado sou eu.

21. Maior preparo das pessoas que fiscalizam, conscientizar os cidadãos.

22. Orientação e fiscalização.

23. Maior fiscalização e conscientização nas escolas.

24. Deveriam de ser aplicadas com mais serenidade, e com muita consciência.

25. Penas maiores para quem polui o ambiente.

26. Distinção do que é mata e pastagem. Pois até a roçada em locais onde a roça já era bem antiga o SEDEMA proíbe.

27. Deve haver bom senso.

28. Tem que ter mais fiscalização.

29. Não tenho opinião sobre o assunto.

30. Deveriam ser mais brandas e divulgar para a população. O IBAMA não tem gente para

fiscalizar, deveria ter mais.

\section{Q.28. De quem você acha que é a obrigação de proteger a Natureza?}

1. De todos.

2. Todo mundo que usa está prejudicando. Não dá para parar porque todo mundo tem que viver. Todos. Da cidade até os malandros.

3. Do próprio homem.

4. De todo mundo.

5. Lei. Para pôr ordem.

6. De todos.

7. Todos. O povo brasileiro inteiro.

8. Minha e de todos. Cada um faz a sua parte. 
9. Do próprio governo, com fiscalização severa.

10. De todo ser humano. Todos fazendo sua parte, melhora.

11. Do povo. O governo tem que exigir.

12. De cada um que tenha o poder dela na mão.Todos tem que fazer a sua parte. Se todos fizessem a parte dele, não precisava lei, nada. Seria maravilhoso. Por isto eu acho que deve entrar o governo no meio, porque por bem, o povo não cumpre.

13. Aqui seria o proprietário da terra, mas o governo tem que ajudar. Deveria dar incentivo fiscal.

Eu quis comprar um Pau Brasil para plantar na beira do rio e tive que comprar em Limeira.

14. De todo mundo. Particulares e Gov. Municipal, Estadual e Federal.

15. De todos.

16. É do governo.

17. A obrigação é de todos.

18. A obrigação de proteger é de todos.

19. De todos, deve iniciar na escola, na formação... . A educação das crianças do campo não pode ser igual a das crianças da cidade.

20. Todo mundo.

21. Todos nós.

22. É de cada proprietário, mas cabe ao governo fiscalizar.

23. De todos, principalmente de quem manda.

24. De todos, principalmente de quem vive junto à Natureza.

25. Dos governos federal, estadual e municipal, hoje estamos sem energia elétrica num país que possui muita água, falta vontade política para corrigir essas coisas.

26. De todos, desde que seja feito um programa para todo tipo de produtor.

27. De todos.

28. Dos proprietários da terra.

29. De todos os proprietários.

30. De todos nós.

Q.29. Na sua opinião, de quem deveria ser a água que está dentro de sua propriedade (direito)? E de quem deveria ser a responsabilidade sobre ela (dever)?

1. Do proprietário.

2. Todo mundo pode ir usando. A obrigação tem que ser de todos, não só do proprietário.

3. A água que está na minha propriedade é para o meu uso. Meu domínio, mas não exclusivo. 0 proprietário também tem responsabilidade sobre ela.

4. Legalmente é de todos. Cada proprietário deve cuidar quando passa na sua propriedade. Não pode pensar só no seu nariz. Tem que pensar nos netos.

5. Do povo. O proprietário deve conservar.

6. Desde que não se mude o cursos do rio, nascente ou ribeirão, do dono. Se houver irregularidade, tem que ser punido.

7. Do proprietário. Ele abre o poço. A água é deixada por Deus para nós. A cidade não deve poluir. Quem deve conservar é a cidade, o povo.

8. O rio é da comunidade. O poço, não sei. Se o vizinho precisar de água eu dou. A responsabilidade deve ser de todos.

9. Da família. E de algum vizinho que necessita. Responsabilidade nossa. Os outros de fora não resolvem nada.

10. Depende da água. Antes, só os rios grandes eram da marinha. O proprietário deveria ter um pouco de autoridade para correguinho pequenininho. Quem quer a água deve cuidar. Se unir. 11. Do governo. A responsabilidade também.

12. Achava que seria da pessoa que tá ali (o proprietário). E o que sobra os outros poderiam usar. A responsabilidade seria do proprietário. 
13. Estou vendo o movimento! Não tem como controlar a cobrança. Mas acho que deveria ser do proprietário porque ele está muito sacrificado. Tem muito imposto. Não agüento mais. 14. É difícil dizer. Não tenho opinião formada. Se você tem uma propriedade, não dá direito de outros explorarem. Nem o governo. Obrigação deveria ser dos proprietários.

15. De todos também.

16. Deveria ser do dono da terra.

17. O direito da água é de todos, porém somente o proprietário tem o direito de usufruir e a responsabilidade sobre ela.

18. A água é de todos, porque ela chega no rio, porém é dever do proprietário cuidar dessa água.

19. De todos, o rio deve ser encarado como um todo. Todos devem ter responsabilidade - desde a nascente até as cidades.

20. De todo mundo. Do proprietário.

21. Deve ser patrimônio, responsabilidade de uso do proprietário.

22. Ninguém deveria ser dono da água. A água é livre, mas o governo deve obrigar a preservar.

23. Do dono da propriedade. O próprio dono.

24. Do dono do sítio. Do proprietário, mas deve ter ajuda de órgãos.

25. Bem estudada a lei, essa água deveria ser cuidada pelo Município, e o Município deveria ajudar a conservar as nascentes.

26. Da cidade, mas sob responsabilidade do dono.

27. Da cidade.

28. Um pouco da água que passa na minha propriedade, tenho direito de usar.

29. Não sei pois não uso.

30. De todos.

Q.30. E a faixa na beira dos cursos d'água? De quem deveria ser a responsabilidade de preservá-la / plantá-la?

1. O proprietário deveria plantar, mas com ajuda.

2. Depende. O governo deveria indenizar os 30 metros. Entrar em acordo. Proprietário planta e o governo ajuda.

3. É polêmico. A prefeitura está fazendo de boa vontade. Mas deveria agir mais longe da cidade. Teria que ser a cargo do proprietário, desde que houvesse mais poder do proprietário.

4. Do proprietário.

5. O proprietário deve plantar e fazer cerca.

6. O dono não pode derrubar árvores, mas no entanto, na maioria das vezes, não pode ser responsabilizado.

7. Do governo.

8. Se a propriedade for minha, eu refloresto.

9. O próprio proprietário. Ele sabe o que tá faltando. Ibama e outras coisas, não estão sabendo o que está faltando.

10. Quem quer fazer, faz. Mas o governo pode ajudar quem não tem capacidade. O dinheiro é do próprio povo. Contribuinte.

11. Do dono da terra.

12. As duas partes. O dono e o governo. Se outro chegar e destruir, o governo entra.

13. Eu sou obrigado a plantar porque o governo não planta. Não concordo, mas se tem, tem.

14. Todos tem que preservar.

15. De todos.

16. Se o governo ajudasse, deveria plantar, mas com a permissão do dono.

17. A responsabilidade deveria ser do governo e do proprietário, porque não temos como controlar a entrada de outras pessoas pelo rio. 
18. A responsabilidade deve ser dividida entre o proprietário e o poder público, em parcerias que incentivem o plantio.

19. De todos. O problema é responsabilidade quanto ao plantio, deve haver parcerias para ajudar.

20. Do proprietário, mas é bom que venha ajuda de alguém.

21. Do proprietário.

22. A responsabilidade deveria ser do Governo.

23. Do proprietário, mas com incentivos do governo.

24. Do proprietário, mas com ajuda desses órgãos responsáveis.

25. Dos governantes, federal, estadual e municipal.

26. Deveria ser pública e de responsabilidade de todos.

27. De todos.

28. Dos proprietários, mas não há condições e eles precisam de ajuda da algum órgão competente.

29. Do governo, pois o proprietário não tem condições.

30. O proprietário e a prefeitura deveriam preservá-la, mas quem deveria plantar era o governo.

Q.31. Você já ouviu falar de alguma campanha ou programa de auxílio ao florestamento em propriedades rurais? Qual? Este programa Ihe pareceu bom? Você aderiu ou gostaria de aderir a ele?

1. Não. Gostaria de participar se me procurassem.

2. Sim. Projeto Corumbataí, através de reunião na Cooperativa. Acho que o programa deveria atingir a todos. Às vezes refloresta um e deixa o outro. Tinha que ser todos juntos para dar certo. Reflorestar de cima porque a erosão vem de cima. Não sabia que davam mudas. Não gostaria de participar, a não ser que o governo pagasse para reflorestar.

3. Sim. O Projeto do João (Corumbataí). Aderi em uma das propriedades. Agora melhorou a qualidade das mudas e o método de plantio.

4. Sim. A prefeitura já deu várias mudas. A ESALQ também. Gostaria de participar do programa dentro das suas limitações. Concordaria em falar com o arrendatário.

5. Não. Mas gostaria de participar de um. Acho boa a idéia.

6. Não. Mas gostaria de aderir a um deles.

7. Já fui em uma reunião na Costa Pinto. Sei da Secretaria do Meio Ambiente. O programa parece bom, mas só aderiria se cuidasse sempre. Tem árvore que demora mais para pegar e eu não quero cuidar depois de um ano. Estou cansado devido à idade.

8. Não. Eu acho certo ter o programa e já recebi mudas da ESALQ e do viveiro da prefeitura. Mas eu tenho um laudo feito por engenheiro que não conseguiu. Ele plantou numa área que encharcou. Mas se mudar a posição para além da área de encharcamento, invade a área que eu uso.

9. Na beira do rio é bom plantar para não dar desbarrancamento e não obter perigo de mudar o curso. Mas só tô de acordo com muda de árvore boa. Fraquinha não, não segura. Árvore de cerne dá o pião e resiste à força da água. Tem força para segurar. É melhor pé de manga para enraizar. No momento não estou interessado em aderir.

10. Do Consórcio e da Casa da Lavoura. Não sei se tá certo. Se eu quiser outro tipo de árvore, de onde vai vir? Cedro, Cambará, Jatobá, Guarantã, Jaboticabeira, Maçaranduba. Participei da reunião mas não tem o que fazer. Não tenho espaço.

11. Não. Mas gostaria de saber mais e estudar uma proposta.

12. Projeto Corumbataí. Achei bom e já aderi.

13. Não me procuraram. Acho bom que tenha pois vai ter que fazer mesmo. Mas tem que deduzir esta área dos impostos. E um ano não dá para formar a mata (formiga, enchente, pescador).

14. Sim. É razoável. Aderi. Doam mudas mas não adaptam melhor as espécies. Teria que dar 
além da muda, orientação. Tem muito lugar encharcado que não tá adiantando.

15. Sim. Ouvi falar.

16. Sim. Participo do programa do Consórcio. Eles não vêm cuidar. Tem mudas morrendo.

17. Não, uma vez fui contatado pela prefeitura para o cadastramento.

18. Não.

19. Sim, mas não sei onde ficam.

20. Ouvi falar que a Floresp fornece as mudas.

21. Sim.

22. Conheço o Programa da Floresp, que faz reflorestamento de Eucalipto. O programa é muito bom, mas eu não aderiria por causa da cana.

23. Nunca.

24. Sim, mas é muito pouco e não sei como funciona.

25. Existe mas ninguém faz nada para melhorar isso. Tudo que traz benefícios para a coletividade é bom.

26. Sim, a do Corumbataí. Já aderi ao programa.

27. Sim. Corumbataí.

28. Sim. Minha área teve árvores plantadas pelo Consórcio da Bacia.

29. Sim, mas não funcionou.

30. Vi alguma coisa na TV.

Q.32. Você conhece alguma propriedade que tenha tido alguma área reflorestada? Caso positivo, você sabe no que isto ajudou ou atrapalhou a propriedade e o proprietário?

1. Não.

2. Não, só a usina.

3. A Costa Pinto. Para a usina foi ruim porque foi embaixo de multa. Na minha área foi diferente.

4. Sim. Na região onde eu moro. O Eucalipto acabou com a água, daí, mataram ele.

5. Sim, o sítio em cima do Motel. Achei bom pq se eles não plantam outra coisa, pelo menos plantam árvore.

6. Sim. Mas não sei se ajudou ou atrapalhou.

7. Só a usina. O do meu primo morreu pq secou. A época de plantio certo é outubro, nov. e dez.. Melhorou a água depois que entrou as leis. Nem a criação tomava água do rio pq era muito ruim.

8. Só a usina. Acho que tá ficando boa. Eu não visitei. Toda tentativa é válida!

9. A Usina e o vizinho do porto de areia. Foi bom para a propriedade. Tirou a draga mais para longe.

10. Usina. Melhorou.

11. Não.

12. Só o pessoal do porto de areia plantou alguma coisa. E a usina. Por enquanto é muito pouco, não representa nada. É muito recente. Para ver diferença precisa de 10 anos.

13. Não. Tenho um vizinho que vai ceder área para plantar porque o pessoal do porto de areia tem que plantar mas não tem aonde.

14. Sim. Mas é difícil dizer se ajudou pois só tem 3 ou 4 anos. Tá se desenvolvendo. Tem mais passarinho. Beneficia a Natureza.

15. Sim. Sempre é bom.

16. Não deu tempo de ver.

17. Não.

18. Na área do vizinho que extrai areia do rio. Ele foi obrigado a plantar árvores.

19. Sim, a usina. Acaba colocando ordem na casa. Eles não gostam de fazer, mas se é bom para todo mundo, tem que fazer.

20. Sim, atrapalha porque o dono assume responsabilidade pela área, mas ajuda a Natureza. 
21. Sim. Aumentou água, fauna, propriedade mais bonita, controle de erosão.

22. Sim. O reflorestamento foi bom, não atrapalhou, é um bom investimento.

23. Não.

24. Conheço uma, mas não sei como foi o resultado.

25. Existe e ajudou muitos proprietários, principalmente no Nordeste.

26. Sim, reflorestei porque havia desmatado.

27. Sim.

28. Muitos vizinhos.

29. Sim, a minha mesmo, mas não foi para frente, morreu tudo.

30. Sim, soube de pessoas que plantaram Eucalipto para madeira.

\section{Q.33. Você gostaria de participar de algum curso sobre preservação da natureza e legislação do meio ambiente? Onde e quando gostaria que fosse o curso?}

1. No momento não.

2. É difícil pois não tenho tempo e saúde. O ideal é vir alguém ensinar aqui. Marcar horário, de preferência à noite, na entresafra. Na usina ou cooperativa. Se todos forem a gente vê.

3. Se puder na época, tudo bem. Na ESALQ ou na usina. Melhor na entresafra e à noite.

4. Se avisar com antecedência, terá adesão. Participarei se estiver programado. Poderia ser no salão da Igreja de Santa Olímpia.

5. Não pq não tive estudo. Mas gostaria de ler sobre assuntos de interesse. Para os outros, é melhor na entresafra e à noite.

6. Sim. Em qualquer lugar de Piracicaba, de preferência na Usina. De novembro a janeiro, no período noturno.

7. Não. Quero sossego. Distância.

8. Estou sempre participando. Tanto faz o lugar.

9. Sim. Em qualquer tempo. É melhor de manhã. Onde marcar vou procurar comparecer, mas é melhor que seja perto e depois que acabar a colheita.

10. Gostaria mas não tenho certeza de participar. À noite, não posso deixar a propriedade sozinha. Deveria ser perto e na entresafra.

11. Difícil porque trabalho com comércio em Americana, durante o dia todo.

12. Sim. No tempo da chuva. Melhor à noite (das 20 às $22 \mathrm{~h}$ ). Dezembro a Janeiro o povo tá folgado. Planta no começo de março e abril. Melhor que seja na Usina. Todo mundo tem carro. 13. Sim. Se quiser fazer no Sindicato Rural, tem 400 associados. Não pode ser de sábado e tem que dar brinde, camiseta, salgadinho, etc. É melhor à noite.

14. Depende do curso. Na usina. Melhor época é na entresafra: final de outubro até o começo

de maio. Qualquer período do horário comercial.

15. Sim, se tiver disponível eu vou.

16. Não posso ir. Fale com meu funcionário.

17. Sim, qualquer época e horário.

18. Sim, de preferência em algum local na cidade. Na época antes do plantio de árvores, talvez em julho que é férias, e de preferência à noite.

19. Sim, na cooperativa.

20. Sim, no bairro.

21. Sim. Na ESALQ.

22. Não tenho interesse em participar, mas acho importante para o pessoal. Informação nunca é ruim. Poderia convocar a vizinhança e proprietários numa fazenda durante a época de não colheita. O curso deveria ser no período diurno.

23. Sim. Na ESALQ e em qualquer época do ano.

24. Sim. Poderia nos ajudar bastante. Tem que ser num lugar de fácil acesso e em qualquer época do ano. 
25. Sim, principalmente em nossa cidade.

26. Sim, no centro rural de Tanquinho. Época: fora da época de plantio e colheita. Horário:

Sábado de manhã.

27. Sim, na entressafra, sábado.

28. Não tenho interesse.

29. Não, pois sou muito velho.

30. Sim. Em qualquer lugar.

\section{Q.34. Qual a melhor forma de contactá-lo?}

1. Telefone.

2. Telefone.

3. Telefone.

4. A melhor forma de divulgar o curso é através da associação de Bairro.

5. Telefone.

6. Pelo endereço da correspondência.

7. Telefone.

8. Telefone.

9. Telefone da minha filha. Aí meu filho vai junto. Ele também tem terreno.

10. Vindo aqui.

11. Telefone.

12. Vindo aqui.

13. Telefone.

14. Telefone.

15. Telefone.

16. Telefone.

17. Telefone.

18. Telefone.

19. Telefone.

20. Telefone.

21. Telefone.

22. Telefone.

23. Telefone.

24. Telefone.

25. Telefone.

26. Pelo telefone.

27. Telefone.

28. Por telefone.

29. Telefone.

30. Telefone.

\section{Q.35. Você gostaria de receber mais informações sobre:}

1. Não sei.

2. Sobre curva de nível (não conseguiram fazer). Caça e pesca. Leis na beira do rio (30 metros é muito!). Como fazer valer para todos.

3. Programa de auxílio ao florestamento, legislação, proteção à Natureza, alternativas econômicas envolvendo árvores (Como se virar até o primeiro corte do eucalipto?).

4. Não sei.

5. Não sei. 
6. Alternativas econômicas envolvendo árvores.

7. Legislação florestal e proteção à Natureza. Através de revista. Já recebi uma de Viçosa.

8. Tenho uma mala de informações sobre meio ambiente e legislação devido ao Rima. Gostaria de saber se posso receber auxílio pois ao dragar o rio, estou despoluindo. Porque o Governo cobra a água. Em 1 ano, tiro mil metros de entulho do rio e levo para aterrar buracos de olaria. Assim, eu colaboro e queria receber uma ajuda por isto.

9. Legislação florestal.

10. Vários assuntos.

11. Carneiro, represa, autorizações, mudas, plantio em área encharcada.

12. Legislação florestal.

13. Subsídios a produtos. Ex.: leite.

14. Legislação florestal e impostos. O porque de tudo isso.

15. Legislação.

16. Dinheiro para quem tem árvore.

17. Programa de auxílio ao florestamento, legislação florestal, técnicas de plantio de árvores. Informação sobre doação de mudas e sementes, espécies a serem plantadas (espécies e locais corretos de plantio).

18. Programas de auxílio ao florestamento, legislação florestal e proteção à Natureza.

19. Legislação florestal, alternativas econômicas envolvendo árvores e vários assuntos como formas de usar insumos sem causar danos, cana orgânica e alternativas de agricultura.

20. Programas de auxílio ao florestamento.

21. Alternativas econômicas.

22. Não gostaria de receber nenhuma informação.

23. Proteção à Natureza.

24. Proteção à Natureza e vários outros assuntos.

25. Proteção à Natureza. Todos os outros assuntos são bons.

26. Programas de auxílio ao reflorestamento, legislação florestal, proteção à Natureza, alternativas econômicas envolvendo árvores, técnicas de plantio de árvores.

27. Vários assuntos.

28. Não tenho interesse.

29. Não tenho interesse por ser muito velho.

30. Legislação florestal. 
ANEXO D. Mapa da Rede Hídrica da Microbacia Tamandupá

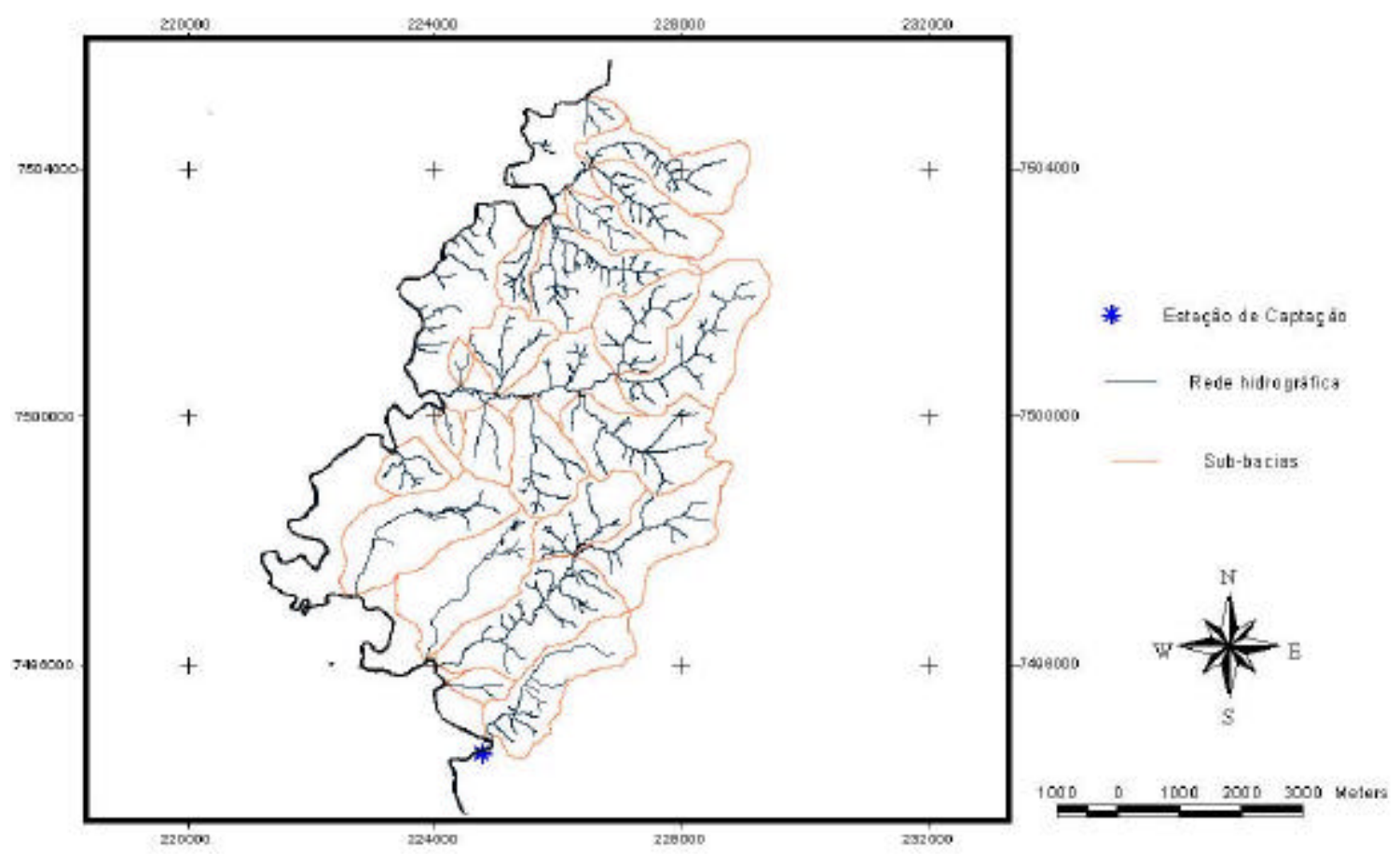

Fonte: Projeto Corumbataí - IPEF/SEMAE (2001). 


\section{ANEXO E. Mapa de Cobertura Florestal da Microbacia Tamandupá}

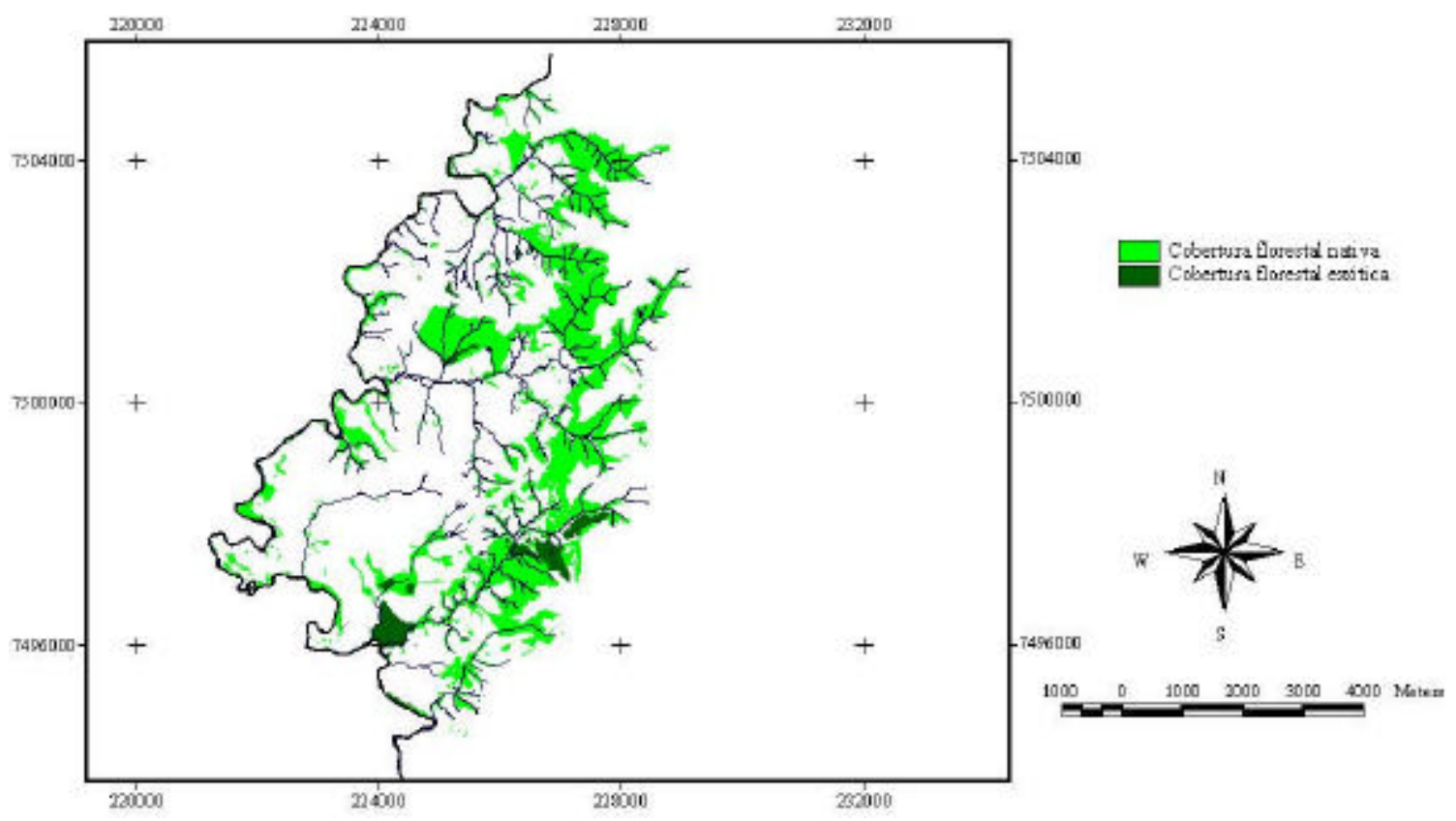

Fonte: Projeto Corumbataí - IPEF/SEMAE (2001). 


\section{ANEXO F. Atividades realizadas durante o desenvolvimento da pesquisa}

$\mathrm{O}$ relato destas atividades tem o intuito de orientar futuros pesquisadores no sentido de aprofundar conhecimentos e instrumentalizar-se para o trato de questões complexas como as propostas no presente trabalho.

a) Debates sobre alterações no Código Florestal

Foram acompanhados diversos debates, cursos, reuniões e palestras com o intuito de aprofundar as discussões a respeito das alterações no Código Florestal Brasileiro (Lei 4.771/65). Parlamentares, estudantes, entidades ambientalistas e algumas facções da sociedade civil, dedicaram-se a formular propostas e a debater os projetos de lei que propunham alterações expressivas no referido código. Durante este processo, foi possível analisar as dificuldades e implicações da aplicação das leis, as demandas dos proprietários rurais, as divergências entre os setores ambientalista e ruralista e as potencialidades que acompanharam (e acompanham) as discussões. Dentre estas potencialidades pode-se destacar a abertura do diálogo para a promoção de parcerias, a necessidade de organização dos setores envolvidos, a importância da participação popular, a busca por conhecimentos para embasar as tomadas de decisão, etc.

b) Reuniões promovidas pela CATI, Prefeitura e Consórcio Intermunicipal das Bacias do Piracicaba, Capivari e Jundiaí

Durante o período de 2 anos, houve participação da pesquisadora em diversas reuniões realizadas em Piracicaba e região. O principal objetivo foi a familiarização com proprietários rurais e com profissionais que atuam no setor, como técnicos da Prefeitura, da Casa da Agricultura, do DEPRN, do Consórcio de Bacias Hidrográficas, do SEMAE, das Universidades da região, etc, bem como, para conhecer os programas relacionados ao tema da presente pesquisa, desenvolvidos por estes grupos.

c) Congressos, Seminários e Cursos

A participação da pesquisadora nos eventos listados a seguir, contribuíram para a aquisição de conhecimentos para aprofundamento teórico, atualização e coleta de dados importantes para a pesquisa. Seminários: "Questões Sócio-Ambientais na Contemporaneidade: Os Papéis da Educação Ambiental"; "Dia Internacional da Água"; 
"15 anos da Lei de Ação Civil Pública - Polêmicas e Controvérsias - Evolução Legislativa e Tendências Jurisprudenciais". Congressos: "IV e V Congresso Internacional de Direito Ambiental"; "Congresso Internacional de Agroecologia". Palestra "Rubem Alves - O Educador como Feiticeiro". Cursos: "Educação Ambiental na Ótica de Gênero"; "1ํ Curso Sobre Legislação Florestal / Ambiental"; "Curso de Artesanato com fibras - Projeto Banana"; "Primeiro Curso de Atualização em Direito Ambiental". Apresentação de trabalhos em Congressos: "I Encontro de Pesquisa em Educação Ambiental"; "III Simpósio sobre Recuperação da Cobertura Florestal da Bacia do Rio Corumbataí".

d) Cursos ministrados

Experiência didática foi adquirida no decorrer da pesquisa através de práticas pedagógicas como palestras e cursos para diversos públicos:

- Organização e realização de palestras pertencentes ao Curso "Proteção à Natureza e Legislação Ambiental", para proprietários rurais da região de Piracicaba/SP;

- Coordenação e Palestras no Curso de Extensão Universitária e Difusão Cultural: "Legislação e Educação Ambiental" do Departamento de Ciências Florestal da ESALQ/USP. Duração: 16 horas. Piracicaba / SP.

- Palestra no "2o Curso Sobre Legislação Florestal / Ambiental", promovido pelo Instituto de Pesquisas e Estudos Forestais - IPEF. Duração: 8 horas. Piracicaba/ SP.

- Aulas referentes ao módulo de Direito Ambiental, do curso de Pós-Graduação em Gestão Ambiental da USP. Departamento de Saúde Pública. Duração: 24 horas. São Sebastião / SP.

- Palestra sobre "Legislação e Educação Ambiental Como Instrumentos na Conservação de Ecossistemas". XVI SECAL - Semana de Ciências Agrárias e Tecnológicas de Lavras. Duração: 4 horas. Universidade Federal de Lavras / MG.

- Palestra sobre o tema "Modificações no Código Florestal Brasileiro e Participação Estudantil". Instituto de Biociências - USP / São Paulo. Duração: 4 horas.

e) Monitoria em disciplina 
Efetuou-se monitoria na Disciplina "Política, Legislação e Administração Florestal", de responsabilidade do Prof. Dr. Marcos Sorrentino, durante o segundo semestre do ano de 2001. Esta atividade contribuiu para o envolvimento de alunos de graduação na pesquisa, orientando-os a dialogar com proprietários rurais da região. $\mathrm{O}$ aprendizado sobre a forma de orientar pessoas para abordagem e aplicação de questionários, foi bastante enriquecedor e os dados obtidos neste processo foram também utilizados nesta pesquisa.

f) Diagnóstico de iniciativas em Educação Ambiental na Bacia do Corumbataí

Com o intuito de adquirir subsídios para a elaboração de um Programa de Educação Ambiental para ser parte integrante do plano diretor da Bacia do Rio Corumbataí, efetuou-se um breve levantamento de iniciativas de Educação Ambiental, com especial interesse àqueles projetos voltados à recuperação florestal e qualidade da água em andamento na Bacia. Constatou-se que são desenvolvidos poucos trabalhos com este enfoque na região, sendo que estes são ainda, em sua maioria, pontuais, tímidos e desarticulados. Há pouco apoio institucional e quase nenhuma integração entre os grupos particulares que promovem estas práticas.

g) Participação na Elaboração do Programa de Educação Ambiental da Bacia do Rio Corumbataí

Considerando o diagnóstico efetuado e as sugestões das pessoas entrevistadas durante o mesmo, elaborou-se uma proposta de Programa de Educação Ambiental para a Bacia do Rio Corumbataí (Anexo G). Esta experiência também representou importante subsídio para propor uma intervenção educacional e visualizar as possibilidades de continuidade dos trabalhos junto ao público alvo.

h) Curso de Disciplinas de Direito e Direito Ambiental

O embasamento teórico adquirido nas diversas disciplinas cursadas junto ao curso de Direito da Universidade Metodista de Piracicaba - UNIMEP, contribuiu para um melhor entendimento do papel do Direito na sociedade e para a compreensão de algumas questões jurídicas básicas que puderam ser abordadas nos cursos realizados. A disciplina de Direito Ambiental cursada na mesma Universidade, também teve papel importante para a discussão e debate de questões ambientais diretamente ligadas à 
realidade dos proprietários rurais, como por exemplo, questões relacionadas a água, licenciamento, resíduos, propriedade, interesse público, etc. 


\section{ANEXO G. Sugestão de Programa de Educação Ambiental para a Bacia do Rio Corumbataí}

Autores: Isis Akemi Morimoto; Flávia Rossi de Moraes; Marcos Sorrentino.

\section{Introducão}

A presente Proposta de Programa de Educação Ambiental é parte integrante do Plano Diretor da Bacia do Rio Corumbataí, elaborado com o intuito de, entre outros objetivos, recuperar a cobertura florestal desta bacia hidrográfica.

A associação entre Educação Ambiental e recomposição florestal, vem da necessidade de maior envolvimento da população local neste processo de recuperação. Esse envolvimento se dará através da sensibilização, valorização e participação, proporcionadas por ações educacionais. A 'Declaração da ONU sobre o Meio Ambiente Humano" (1972), reforça esta idéia em seu artigo 19: "É indispensável um trabalho de educação em questões ambientais, visando tanto as gerações jovens, como os adultos, dispensando a devida atenção aos setores menos privilegiados, para assentar as bases de uma opinião pública bem informada e de uma conduta responsável dos indivíduos, das empresas e das comunidades, inspirada no sentido de sua responsabilidade, relativamente à proteção e melhoramento do meio ambiente em toda a sua dimensão humana".

A respeito da valorização do meio ambiente, Libório (1994) afirma que é preciso ampliar o universo de informações e de conhecimento sobre a importância não só do patrimônio florestal, como de toda a natureza. "Tendo conhecimento claro da situação, as pessoas tendem a despertar sua afetividade e, com isso, passam a valorizar a paisagem. A valorização implica atribuir a este recurso da natureza, as qualidades que o tornarão objeto de interesse e de proteção para toda a sociedade".

\section{Definicões, Princípios e Objetivos da Educacão Ambiental}

A Educação Ambiental refere-se, especialmente, à busca de qualidade de vida, através da melhoria das relações entre o ser humano e o meio ambiente, natural ou 
não. Ela lida com o potencial das pessoas para entender e transformar o meio ao seu redor.

Mas o que é qualidade de vida? Há múltiplas definições para a expressão "qualidade de vida", mas todas elas, certamente, incluem saúde e desenvolvimento. Estes dois fatores são extremamente relacionados ao meio ambiente; a saúde de uma pessoa está ligada às condições do local em que ela vive, assim como o desenvolvimento real e contínuo - diferente do puro acúmulo de riquezas e progresso tecnológico - depende do uso racional dos recursos naturais (Mergulhão \& Vasaki, 1998).

Segundo Pádua (1997), a Educação Ambiental surgiu como uma nova forma de encarar o papel do ser humano no mundo. Na medida em que parte de reflexões mais aprofundadas, a educação ambiental é bastante subversiva. Na busca de soluções que alteram ou subvertem a ordem vigente, propõe novos modelos de relacionamentos mais harmônicos com a natureza, novos paradigmas e novos valores éticos. Com uma visão holística e sistêmica, adota posturas de integração e participação, onde cada indivíduo é estimulado a exercitar plenamente sua cidadania.

Existem ainda, muitas outras definições para Educação Ambiental, como as apresentadas no Caderno de Conceitos Para se Fazer Educação Ambiental da Secretaria do Meio Ambiente (1997):

- Educação Ambiental é a preparação de pessoas para sua vida enquanto membros da biosfera;

- Educação Ambiental é o aprendizado para compreender, apreciar, saber lidar e manter os sistemas ambientais na sua totalidade;

- Educação Ambiental significa aprender a ver o quadro global que cerca um problema específico - sua história, seus valores, percepções, fatores econômicos e tecnológicos, e os processos naturais ou artificiais que o causam e que sugerem ações para saná-lo;

- Educação Ambiental é a aprendizagem de como gerenciar e melhorar as relações entre a sociedade humana e o ambiente, de modo integrado e sustentável;

- A Educação Ambiental significa aprender a empregar novas tecnologias, aumentar a produtividade, evitar desastres ambientais, minorar os danos existentes, conhecer e utilizar novas oportunidades e tomar decisões acertadas; 
- Educação Ambiental é fundamentalmente uma educação para a resolução de problemas, a partir das bases filosóficas do holismos, da sustentabilidade e do aprimoramento.

Troppmair (1997) define Educação: "não é simplesmente transmitir conhecimentos formais de geração para geração. Educar não é apenas ensinar soma e multiplicação, leis da física, capitais e rios de países, nomes e animais ou ossos do esqueleto. Educar tem um sentido muito mais amplo e mais profundo pois educar é habilitar o ser humano para desenvolver-se plenamente: física, intelectual, espiritual e socialmente. Educação Ambiental é possibilitar o desenvolvimento pleno do homem, tendo como parâmetro as grandes Leis da Natureza. 'Somos parte da terra e ela faz parte de nós' diz o chefe indígena. Portanto, Educação Ambiental significa entender as relações de homem / meio ambiente e vice-versa."

Ainda segundo Troppmair, os objetivos da Educação Ambiental são muitos, destacando-se apenas 10 itens considerados por ele mais importantes:

11. Formar pessoas (crianças, jovens e adultos) conscientes da responsabilidade que têm para o Meio Ambiente;

12. Estimular atitudes racionais para o uso do Meio Ambiente, visando o ecodesenvolvimento, o desenvolvimento sustentável, ou seja, um desenvolvimento econômico e social que respeite as grandes Leis da Natureza como equilíbrio, recomposição, elasticidade, etc;

13. Observar, indagar e posteriormente entender o funcionamento do Sistema Natureza;

14. Conscientizar que a Terra é um sistema único e dinâmico, chamado GAIA (comparando-a a um ser vivo e associando seus diferentes ecossistemas a órgãos);

15. Deixar claro que pertubações ou destruições de parte da GAIA se refletem de forma negativa sobre TODO o sistema;

16. Reconhecer que o homem é parte integrante e não dono (e muito menos exterminador) da Natureza;

17. Enfatizar a urgência do redirecionamento do uso dos recursos naturais e de mudança da mentalidade e dos padrões da Sociedade de Consumo. Incentivar os processos de reciclagem; 
18. Preservar a biodiversidade entre as diversas espécies e entre uma mesma espécie pois não existem dois seres iguais;

19. Manter e, sempre que possível, melhorar a qualidade ambiental e de vida;

20. Formar cidadãos conscientes de suas responsabilidades e que sejam atuantes na sociedade.

Meadows (1989) também enumera razões para que se promova Educação Ambiental:

- Aprender, partindo dos exemplos de outros, a evitar seus erros e imitar seus sucessos;

- Prever e evitar desastres ambientais, especialmente aqueles irreversíveis;

- Fazer render ao máximo os recursos naturais com que o país foi dotado; Administrar estes dons de modo eficiente, produtivo e sustentável;

- Ser capaz de implementar políticas como o reflorestamento, a reciclagem, ou o planejamento familiar, que requerem a cooperação de todas as pessoas;

- Economizar dinheiro, evitando os danos ambientais no lugar de repará-los posteriormente;

- Desenvolver a opinião pública no sentido de evitar o pânico e o exagero, porém respeitando a verdadeira urgência das questões;

- Permitir que as pessoas se tornem cidadãos informados e produtivos do mundo moderno;

- Assegurar um ambiente enriquecedor que dê segurança e alegria às pessoas, ao qual elas se sintam econômicas, emocional e espiritualmente conectadas.

A carta de Belgrado, escrita em 1975 por vinte especialistas em Educação Ambiental de todo o mundo, declara que um dos objetivos da Educação Ambiental é: "Desenvolver um cidadão consciente do ambiente total, preocupado com os problemas associados a esse ambiente e que tenha o conhecimento, as atitudes, motivações, envolvimento e habilidades para trabalhar individual e coletivamente em busca de soluções para resolver os problemas atuais e prevenir os futuros". 
A Conferência Intergovernamental de Educação Ambiental de Tbilisi (1977), recomenda alguns princípios que até hoje são referência para quem pratica Educação Ambiental (MEC, 1998):

13. Considerar o meio ambiente em sua totalidade: em seus aspectos natural, tecnológico, social, econômico, político, histórico, cultural, técnico, moral, ético e estético;

14. Construir um processo permanente e contínuo, durante todas as formas do ensino formal, desde o início da educação infantil;

15. Aplicar um enfoque interdisciplinar, aproveitando o conteúdo específico de cada área, de modo a se conseguir uma perspectiva global da questão ambiental;

16. Examinar as principais questões ambientais do ponto de vista local, regional, nacional e internacional;

17. Concentrar-se nas questões ambientais atuais e naquelas que podem surgir, levando-se em conta a perspectiva histórica;

18. Insistir no valor e na necessidade da cooperação local, nacional e internacional, para prevenir os problemas ambientais;

19. Considerar explicitamente os problemas ambientais nos planos de desenvolvimento e crescimento;

20. Promover a participação dos alunos na organização de todas as suas experiências de aprendizagem, dando-Ihes a oportunidade de tomar decisões e aceitar suas conseqüências;

21. Estabelecer para os alunos de todas as idades uma relação entre a sensibilização ao meio ambiente e a aquisição de conhecimentos, habilidades e atitudes, para resolver problemas e clarificar valores, procurando, principalmente, sensibilizar os mais jovens para os problemas ambientais existentes na sua própria comunidade;

22. Ajudar os alunos a descobrirem os sintomas e as causas reais dos problemas ambientais;

23. Ressaltar a complexidade dos problemas ambientais (...), a necessidade de se desenvolver o sentido crítico, e as atitudes necessárias para resolve-los.

24. Utilizar diversos ambientes com a finalidade educativa, e uma ampla gama de métodos para transmitir e adquirir conhecimento sobre o meio ambiente, ressaltando principalmente as atividades práticas e as experiências pessoais. 
Em 1987 ocorreu a Conferência Internacional sobre Educação e Formação Ambiental em Moscou, na qual foram reafirmadas as propostas de Tbilisi. Segundo Genebaldo Freire Dias, uma das conclusões apresentadas nesta conferência, foi que "os objetivos da Educação Ambiental não podem ser definidos sem que se levem em conta as realidades sociais, econômicas e ecológicas de cada sociedade ou os objetivos determinados para o seu desenvolvimento; deve-se considerar que alguns objetivos da Educação Ambiental são comuns à comunidade internacional".

A Agenda 21, documento elaborado por diversos países durante a Conferência das Nações Unidas sobre Meio Ambiente e Desenvolvimento, Rio de Janeiro - 1992, diz em seu capítulo 4:

A fim de que se atinjam os objetivos de qualidade ambiental e desenvolvimento sustentável será necessário eficiência na produção e mudanças nos padrões de consumo para dar prioridade ao uso ótimo dos recursos e à redução do desperdício ao mínimo. Em muitos casos, isso irá exigir uma reorientação dos atuais padrões de produção e consumo, desenvolvidos pelas sociedades industriais e por sua vez imitados em boa parte do mundo.

Observa-se que em escala mundial é admitida a importância da Educação Ambiental para a solução das questões ambientais e o Brasil possui leis que asseguram sua presença em todos os níveis de ensino (como na própria Constituição Federal de 1988 em seu Artigo 225, ou na Lei 9.795 de 27/04/99 que dispõe sobre a Educação Ambiental).

Porém, apesar de todas as considerações sobre Educação Ambiental acima citadas, nota-se que em geral, as pessoas permanecem ainda bastante distanciadas dos problemas ambientais e não se sentem responsáveis por suas soluções.

Sorrentino (1991) disserta sobre estas questões: "O despreparo, a descrença e a falta de motivação para a participação na resolução de seus próprios problemas aliados a um grande ceticismo sobre a possibilidade de alguma autoridade fazer algo que não seja em proveito pessoal e prejuízo do coletivo - levam os indivíduos a uma postura niilista cada vez maior". Isto gera um distanciamento, que para ser superado, é necessário ir ao centro do indivíduo e trabalhar seus valores fundamentais, promovendo sistematicamente a discussão e o questionamento desses valores.

Deste modo, é imprescindível que Programas de Educação Ambiental estimulem a participação, baseada numa reflexão individual e coletiva sobre o 
exercício da cidadania. Segundo Genebaldo Freire Dias: "Não há uma receita para se elaborar um programa de Educação Ambiental para uma escola ou comunidade; ela dependerá das suas peculiaridades, do seu contexto sócio-ambiental-cultural e político".

\section{Educacão Ambiental na Bacia do Rio Corumbataí}

No intuito de elaborar um Programa de Educação Ambiental para os Municípios integrantes da Bacia do Rio Corumbataí, foi realizado um levantamento das Iniciativas em Educação Ambiental na Bacia, com especial interesse àqueles projetos voltados à recuperação florestal e qualidade da água. Foram contatadas prefeituras municipais, Secretarias de Educação e Meio Ambiente, ONGs, Casas de Agricultura, Instituições de Pesquisa, Escolas, entre outras.

Através deste levantamento, observou-se que nas cidades que compõem a Bacia do Rio Corumbataí - Analândia, Charqueada, Corumbataí, Ipeúna, Itirapina, Piracicaba, Rio Claro, Santa Gertrudes - são desenvolvidos poucos trabalhos em Educação Ambiental, sendo que estas iniciativas são, em sua maioria, pontuais, tímidas e desarticuladas. Há pouco apoio institucional e quase nenhuma integração entre os grupos particulares que promovem estas práticas.

Detecta-se também a falta geral de programas municipais de Educação Ambiental, formais e não-formais, que despertem a percepção da população para 0 meio em que vivem. No âmbito formal existe a necessidade de desenvolvimento de atividades que integrem todas as escolas do município em torno de temas relacionados ao ambiente, abrangendo não apenas questões ligadas ao lixo, água, árvore, ar, mas também, cidadania, solidariedade, cooperação, respeito, participação, etc. No âmbito não-formal, deve-se estimular atividades econômicas, culturais e políticas que possam contribuir para o desenvolvimento sustentável da cidade. O potencial turístico dos municípios, por exemplo, deve ser aproveitado de forma a não comprometer a conservação dos ambientes naturais, orientando e sensibilizando turistas e munícipes.

Nas entrevistas realizadas durante o Levantamento, foram recolhidas algumas sugestões para desenvolver a Educação Ambiental nos municípios. Dentre elas destacamos: 
- "Maior incentivo e colaboração no desenvolvimento de atitudes práticas, pois a teoria só leva ao desperdício de dinheiro e tempo". - Hercília Felipini Penteriche. Professora da Escola Estadual "Professora Erotides de Campos"/ Charqueada.

- "Realização de um seminário anual". - Sonise Virgínia Spironelli. Professora de Ciências e Biologia da rede pública de Piracicaba.

- "Divulgar melhor os projetos. Fazer parcerias, etc". - Valdiza Caprânico. Assessora Ambiental do SEMAE / Piracicaba.

- "Montagem de um Grupo 'virtual' que troque experiências". - Simone Sendin Moreira Guimarães. Bióloga e Educadora Ambiental.

- "Realizar reuniões para integrar pessoas que trabalhem com Educação Ambiental". - Ivana de Campos Ribeiro. Educadora Ambiental / Rio Claro.

- "Implantação efetiva do Núcleo de Educação Ambiental no Horto Florestal de Rio Claro". - Harold G. Fowler. Professor da UNESP / Rio Claro.

- "Integrar a Secretaria da Educação com a Secretaria do Meio Ambiente". Ângela Arruda Prado. Supervisora de Ensino da Secretaria da Educação / Santa Gertrudes.

- "Seminários mensais para trocas de experiências". - Eliete Palumbo Santos. Secretária do Meio Ambiente / Santa Gertrudes.

- "Buscar integrar municípios pequenos e grandes para o turismo". - Moysés Ernesto Pessotti. Secretário de turismo. Prefeitura Municipal / Charqueada.

- "Criação de um centro ou núcleo que monitore todas as atividades envolvidas". - Rogério Garcia. Estudante de Ecologia da UNESP / Rio Claro.

- "Incentivar e capacitar pessoas para trabalho voluntário e fazer Educação Ambiental nas periferias para ajudar na efetivação dos planos diretores dos Municípios. Os educadores devem também se desarmar, acabar com estrelismos e fazer parcerias". - Ivan Takeshi Toyama. Coordenador de Projetos do Consórcio Intermunicipal das Bacias dos Rios Piracicaba, Capivari e Jundiaí / Piracicaba. 


\section{Diretrizes para Educacão Ambiental na Bacia do Rio Corumbataí}

As considerações apresentadas pelos entrevistados, somando-se a observações de campo e experiências adquiridas anteriormente pelos elaboradores do presente Programa, levaram ao apontamento de algumas diretrizes que visam desenvolver e aperfeiçoar a EA na Bacia. Trata-se de uma proposta de fomentar-se uma experiência modelar, que deve estar em consonância com os princípios da Educação Ambiental, descritos no item 1: "Definições, Princípios e Objetivos da Educação Ambiental". Dentre estes princípios, destacamos: participação através cidadania ativa, pertencimento e identidade com o ambiente natural e construído, emancipação através do reconhecimento dos seus direitos e deveres, compromisso com a sobrevivência dos humanos e de todas as espécies e sistemas naturais e com a melhoria da qualidade de vida da região, responsabilidade com a bio e sóciodiversidade, estímulo à autonomia e auto-gestão, variedade de projetos, complexidade teórica e sócio-cultural, continuidade dos projetos independente da alternância de poder nas administrações municipais e instituições responsáveis por políticas, programas e projetos de Educação Ambiental, e conexões que propiciem a integração dos projetos.

As diretrizes ou procedimentos sugeridos para que sejam seguidos esses princípios durante o desenvolvimento da Educação Ambiental na Bacia do Curumbataí, são:

3.1. Criação da Rede da Bacia do Corumbataí

3.1.1. Cursos para Deflagrar a Formação da Rede

3.2. Centros Municipais de Referência em Educação Ambiental

3.3. Secretaria Executiva da Rede

3.4. Diagnóstico Sócio-Ambiental, Educacional e Cultural Participativo

3.5. Páginas Eletrônicas e Material Informativo

3.6. Fundo Regional de Apoio a Pequenos Projetos

3.7. Parcerias

3.8. Ensino Formal e Não-Formal

\subsubsection{Cursos}

\subsubsection{Infra-Estrutura}

3.9. Políticas Municipais de Educação Ambiental 


\section{Detalhamento}

\subsection{Criação da Rede da Bacia do Corumbataí}

Os diversos agentes de Educação Ambiental atuam de forma isolada e com dificuldades próprias. $O$ isolamento dificulta o intercâmbio de informações importantes tanto a respeito do que está acontecendo ambientalmente na região como informações quanto ao aprofundamento dos diversos trabalhos que estão sendo desenvolvidos. $A$ soma dos passos que os educadores ambientais estão dando são a alavancagem dos novos rumos. Existe uma grande perda de esforços quando os trabalhos não somam. $O$ trabalho em rede contribui para mobilizar parcerias, intensificar esforços e aprofundar os trabalhos realizados (REPEA, 2001).

O tecer de uma rede de Educação Ambiental deve acontecer com a participação de todos, garantindo autonomia de ação e sintonia de trabalho, baseado nos princípios do "Tratado de Educação Ambiental para Sociedades Sustentáveis e Responsabilidade Global", elaborado durante a ECO-92.

"Redes são sistemas capazes de organizar pessoas e instituições, de forma igualitária e democrática, em torno de um objetivo comum. Têm um modelo orgânico, vivo, flexível em constante crescimento e mutação, que funciona em mão dupla e que constrói a identidade de um grupo com interesses em comum, traçando um caminho e mantendo a tensão entre os pólos da liberdade e da possibilidade, do respeito à individualidade e da preservação dos valores comuns." (www.neoambiental.com.br).

Entre os benefícios das redes, destacam-se:

-Potencialização das vocações e especialidades;

-Solidariedade e cooperação;

-Ampliação de contatos, aquisição de informações e conhecimento;

-Contribuição na tomada de decisões;

-Integração e inclusão;

-As pessoas ficam "antenadas";

-Diversão. 
"As redes temáticas tem como principal objetivo promover a comunicação, articulação e a organização de ações efetivas em prol dos temas sócioambientais em que cada rede está inserida em nosso país." (www.neoambiental.com.br)

Este conceito de rede deve ser compreendido como uma linha de comunicação entre as pessoas, não necessariamente eletrônica. Pode-se utilizar cartas, telefonemas e encontros presenciais, e também a internet. A Rede Paulista de Educação Ambiental - REPEA, encontra-se em fase de estabelecimento e divulgação, e pretende envolver todos os educadores ambientais do Estado de São Paulo. A mesma possui uma estreita relação com o Consórcio das Bacias Piracicaba, Capivari e Jundiaí (Elo PCJ), que poderá ser fortalecida com a criação de uma rede específica para a Bacia do Corumbataí.

Ressalta-se que formação da rede de comunicações específica entre os profissionais que trabalham com Educação Ambiental na Bacia do Corumbataí, visa facilitar a conexão entre os municípios, integrando, atualizando e estabelecendo um ideário comum entre estes profissionais. Deve também, promover o debate em nível regional, a divulgação de projetos e a criação de um banco de dados, como por exemplo, o cadastro das Iniciativas e a listagem das demandas.

\subsubsection{Cursos para deflagrar a formação da Rede}

A simples formação de redes de discussão e troca de informações, sem um planejamento ou orientação prévia, tem se mostrado ineficiente no que diz respeito ao envolvimento amplo e abrangente de grupos interessados e na continuidade da rede com o passar do tempo. Deste modo, sugere-se a realização de cursos que promovam a emergência e consolidação de uma cultura de redes e a sinergia entre os seus futuros integrantes para que forneçam informações e dados para um planejamento participativo das atividades a serem desenvolvidas pelos grupos.

A perspectiva organizacional em rede e as análises das sociedades contemporâneas como Redes de Comunicação têm sido debatidas (Pastells, ..., Lispck(?) e -----, REPEA, REBEA, -----) por diferentes autores e no interior do movimento ambientalista, como adequada a uma proposta de ecologia democrática e radical como dela nos fala Santos (1997). " “. 
Grahber (2001), elaborou um projeto de fortalecimento da cultura de Rede no elo PCJ da Rede Paulista de Educação Ambiental. A sua implementação pelo Consórcio da Bacia dos Rios Piracicaba, Capivarí e Jundiaí e pela Rede Paulista de E.A. pode ser um excelente parâmetro para o desenvolvimento de projeto semelhante no elo Corumbataí.

\subsection{Centros Municipais de Referência em Educação Ambiental}

A criação de Centros de Educação Ambiental em cada um dos municípios da Bacia poderá funcionar como elo facilitador da criação, enraizamento e manutenção da rede.

A importância dos Centros de Educação Ambiental está também no estabelecimento de um ponto de referência para as instituições e organizações envolvidas com a questão ambiental.

O Conselho Federal de Educação (órgão de formulação da política educacional) aprovou o Parecer 226/87, sugerindo a criação de Centros de Educação Ambiental nos Estados, para atuarem como pólos irradiadores (MEC, 1998). Estes já existem em alguns municípios e funcionam como catalisadores de experiências. As diretrizes dos Centros de Educação Ambiental, relacionadas pelo Ministério da Educação (MEC, 1994), são as seguintes:

- Reflexão crítica sobre a questão ambiental, de forma a rever a relação ser humano/natureza, considerando uma reinterpretação global das relações sócioeconômicas, políticas, culturais e seus impactos no meio ambiente;

- Adoção de propostas pedagógicas e metodológicas que efetivem o processo educativo voltado à promoção da identidade comunidade/meio e para o estímulo às interfaces institucionais e interdisciplinares, numa perspectiva de integração entre $o$ saber formal e o não-formal;

- Centralização de informações com o objetivo de captar, assessorar, divulgar e consolidar um banco de dados em educação ambiental;

- Divulgação de informações sobre as questões ambientais, através dos meios de comunicação, contribuindo para a formação de uma consciência crítica. 
O MEC (1994) também listou objetivos para os Centros de Educação Ambiental, apontando como objetivo geral a promoção da Educação Ambiental como uma das formas de melhoria da qualidade de vida. E como objetivos específicos os listados a seguir:

- Implementar ações de educação ambiental enquanto apoio à educação formal e não-formal;

- Apoiar iniciativas e experiências locais e regionais, incluindo a produção de material instrucional sobre a educação ambiental, de modo a promover soluções aos desafios ambientais da comunidade;

- Promover estudos, pesquisas e eventos sobre a problemática ambiental, dentro de uma perspectiva multi, inter e transdisciplinar, visando a eficácia dos programas e projetos de educação ambiental;

- Capacitar recursos humanos de órgão governamentais e não governamentais, em educação ambiental, visando a consolidação de uma prática de conscientização ambiental;

- Promover a divulgação de conhecimento e de experiências pedagógicas relativas à Educação Ambiental;

- Divulgar as ações de educação ambiental junto aos meios de comunicação de massa.

Silva (2001) realizou um estudo sobre Centros de Educação Ambiental (CEAs) em todo o Brasil, e constatou que estes representam importantes instrumentos de difusão de experiências relativas à educação ambiental no país, porém, são de recente aparição no país, e caracterizam-se por serem iniciativas ainda pouco numerosas e pouco difundidas no Brasil. Os CEAs também não apresentam qualquer tipo de lógica de distribuição espacial. O mesmo autor afirma, no entanto, que facilmente vislumbra-se em nosso país um fabuloso potencial de crescimento de tais iniciativas. "Nossa diversidade cultural, ambiental e étnica proporciona uma infinidade de possibilidades de CEAs, inseridos nas mais diversas situações, atuações, públicos, etc. É possível observar um nítido, porém ainda tímido, crescimento de experiências caracterizadas como centros de educação ambiental no país, com perspectivas de crescimento a curto e médio prazo". Silva (2001) propõe como diretrizes gerais para nortear a criação de novos CEAs bem como aqueles já existentes: 
- que os CEAs estejam envolvidos com os ideais de sustentabilidade;

- que demonstrem na prática cotidiana tais ideais, servindo de exemplo, tanto nas suas atividades, como nos aspectos construtivos e estruturas que o centro dispõe;

- que estimulem a participação da comunidade do entorno bem como do público atendido;

- que não visem lucro através de suas atividades;

- que realizem intercâmbio de informações, idéias, atividades, experiências, etc, entre os CEAs e entre outros setores da sociedade.

Além da criação de Centros de Educação Ambiental nos municípios da Bacia em que eles ainda não existem, é preciso atentar para a efetivação daqueles já criados. Para isto, aconselha-se uma maior divulgação e a busca de credibilidade através da realização de ações mais abrangentes e contínuas, como por exemplo, atividades envolvendo todas as escolas, hospitais, Casas da Agricultura, etc, do município.

Os centros não precisam ser estruturas especialmente construídas para tal fim, no entanto isto é desejável. O Centro pode funcionar dentro de uma instituição com princípios compatíveis, sendo necessário que se faça apenas uma adequação de espaço e infra-estrutura.

Os Centros de Educação Ambiental nos municípios são os elos de referência "para fora" - conexão com os outros municípios - e "para dentro" - conexão com todos os sujeitos (pessoas e instituições) que fazem E.A. no município.

Vale ressaltar que os centros não devem ser utilizados como focos de poder, ou seja, falando sem consentimento em nome de todos os que fazem E.A. no município. Para evitar a centralização de poder, pode-se privilegiar uma política de administração periódica, num rodízio entre as instituições que fazem E.A. .

\subsection{Secretaria Executiva da Rede}

A rede deve ser gerenciada por uma Secretaria Executiva, que deverá, além de monitorar o funcionamento da mesma, promover encontros periódicos entre os profissionais que atuam nos centros e nos projetos ligados a eles, bem como seminários, cursos e palestras que contribuam para a formação e aperfeiçoamento de educadores e para a divulgação dos próprios centros. 
A estrutura da Secretaria Executiva pode ser fixa e para isso sugere-se a utilização do Museu da Água em Piracicaba, ou rotativa, sendo que a cada período (pré-determinado) a sede seria instalada em um dos municípios integrantes da Bacia do Rio Corumbataí. A rotatividade proposta busca descentralizar o poder de decisão e baseia-se na troca de experiências entre os municípios integrantes da Bacia.

Essa mesma alternância é a que propomos no interior dos municípios, para a localização e administração dos Centros de Referência.

\subsection{Diagnóstico Sócio-ambiental, educacional e cultural participativo}

Foi realizado um estudo prévio sobre as iniciativas de Educação Ambiental na Bacia e um levantamento sócio-econômico da região, que servirão de base para um diagnóstico aprofundado das condições sócio-ambientais, educacionais e culturais. $O$ diagnóstico deve ser feito de forma participativa, ou seja, envolvendo a comunidade em todas as etapas de planejamento, execução e conclusão do levantamento.

Este diagnóstico aprofundado possibilitará o conhecimento das principais carências em Educação Ambiental, a definição das prioridades de financiamento de projetos e a elaboração de políticas públicas.

\subsection{Página Eletrônica e Material Informativo}

Deverá ser criada uma página eletrônica específica para Educação Ambiental no site do Projeto Corumbataí. Este espaço deverá disponibilizar informações sobre os Centros (CEAs), os projetos em andamento e as demandas, estimulando grupos de discussão e trabalho.

Além da página eletrônica proposta, devem ser editados boletins informativos impressos, vinhetas radiofônicas, documentários e materiais educacionais para programas de rádio e televisão, podendo ser utilizados também em atividades presenciais. 


\subsection{Fundo Regional de Apoio a Pequenos Projetos}

Deverá existir um Fundo de recursos para apoiar financeiramente pequenos projetos em Educação Ambiental. Com recursos iniciais previstos no plano diretor, tal fundo complementará seu orçamento com auxílio da iniciativa pública e privada.

O Fundo estabelecerá diretrizes para financiamento baseadas nos diagnósticos previstos no ítem 3.4., recepção, aprovação e monitoramento destes projetos, objetivando fomentar iniciativas em Educação Ambiental em toda a Bacia.

\subsection{Parcerias}

Deve-se estimular parcerias com Universidades, empresas públicas e privadas, prefeituras e outras instituições, para auxiliar pesquisas, realizar cursos, possibilitar financiamentos, etc.

Uma possibilidade de parceria pode ser estabelecida com o Laboratório de Educação e Política Ambiental, da ESALQ, que periodicamente oferece cursos, palestras e oficinas.

\subsection{Ensino formal e não-formal}

O fortalecimento do ensino formal e não formal é importante pois pode estimular a participação ativa dos indivíduos na comunidade. $O$ educador precisa se atualizar, se aperfeiçoar, tomar contato com idéias novas, métodos e conteúdos para propor atividades participativas, dialógicas. O trabalho com a discussão de valores e padrões de comportamento e consumo, mais do que a mera informação deve ser compromisso na educação formal e não formal, devendo utilizar recursos como os meios de comunicação de massa e comunitários, os grupos de convivencialidade e outras instâncias responsáveis pela manutenção de mudanças culturais.

Os Centros de referência em E.A. nos municípios, devem disponibilizar informações, materiais e cursos para as Redes de Ensino e para as organizações que desenvolvem cursos de E.A. 


\subsubsection{Cursos}

Deverão ser oferecidos cursos de diversos tipos (temas, tempo de duração, grau de especialização, modalidade, etc.) para educadores, profissionais da área e outros interessados. Estes cursos terão a finalidade de enriquecer o repertório daqueles que atuam na área de Educação Ambiental na Bacia, apresentar recursos e métodos pedagógicos e atrair novos adeptos. Os cursos devem incentivar a autonomia, a criatividade e a sensibilidade para a atuação dos educadores.

Também deve-se oferecer cursos para outras clientelas (crianças, jovens, adultos, idosos, políticos,...), outras finalidades (profissionalização, lazer educativo,...), e outras modalidades (atualização, difusão cultural, pós-graduação, dentre outros).

\subsubsection{Infra-Estrutura}

Deve-se disponibilizar todos os itens anteriores para as escolas e outras instâncias de educação, dando-se especial atenção ao apoio a projetos de implementação de Jardins Multifuncionais Educativos (como os já implantados pelo CEAV de Sumaré) e outras experiências implantadas com sucesso, como hortas, SAFs e viveiros escolares, de rádios e jornais comunitários, projetos integrados de coleta seletiva, reciclagem e mudança de hábitos de consumo, dentre outros.

\subsection{Políticas Municipais de Educação Ambiental}

O Plano Diretor de Educação Ambiental da Bacia deve prever fomento de políticas municipais de E.A. as quais, dentre outras coisas, devem estimular a elaboração de um "cardápio anual" das atividades que são oferecidas no município, de forma a democratizar e estimular o acesso a elas por todos os possíveis interessados. 
4. Previsão Orcamentária e Cronograma

\begin{tabular}{|c|c|c|}
\hline ATIVIDADE & $\begin{array}{l}\text { CUSTO (R\$) } \\
\text { Aproximado }\end{array}$ & $\begin{array}{l}\text { DURAÇÃO ou } \\
\text { QUANTIDADE }\end{array}$ \\
\hline $\begin{array}{l}\text { Cursos para a "Formação de } \\
\text { Educadores Ambientais para } \\
\text { Sociedades Sustentáveis" }\end{array}$ & $70.000,00$ por 25 alunos & $\begin{array}{l}\text { Um curso nível } \\
\text { pós-graduação } \\
\text { ano (720 horas) }\end{array}$ \\
\hline $\begin{array}{l}\text { Criação e Manutenção da Rede } \\
\text { da Bacia do Corumbataí }\end{array}$ & $\begin{array}{l}\text { 2.000,00 para um } \\
\text { funcionário especializado, } \\
\text { por mês }\end{array}$ & Indeterminada \\
\hline $\begin{array}{l}\text { Centros de Referência em E. A. } \\
\text { Construção de prédio próprio em } \\
\text { local (terreno) doado }\end{array}$ & $\begin{array}{l}50.000,00 \text { para a } \\
\text { construção do centro }\end{array}$ & $\begin{array}{l}\text { Um para cada } \\
\text { Município }\end{array}$ \\
\hline $\begin{array}{l}\text { Centro de Referência em E. A. } \\
\text { Adequação de local }\end{array}$ & $\begin{array}{l}30.000,00 \text { compra de } \\
\text { móveis e microcomputador }\end{array}$ & $\begin{array}{l}\text { Para municípios } \\
\text { que não vão } \\
\text { construir }\end{array}$ \\
\hline Secretaria Executiva da Rede & $\begin{array}{l}\text { 2.000,00 para um } \\
\text { funcionário especializado, } \\
\text { por mês }\end{array}$ & $\begin{array}{l}\text { Uma só } \\
\text { secretaria para } \\
\text { todos os } \\
\text { municípios }\end{array}$ \\
\hline $\begin{array}{l}\text { Diagnóstico Sócio-Ambiental, } \\
\text { Educacional e Cultural } \\
\text { Participativo }\end{array}$ & $200.000,00$ & De 1 a 2 anos \\
\hline $\begin{array}{l}\text { Páginas Eletrônicas (elaboração) } \\
\text { e Material Informativo (edição } \\
\text { mensal) }\end{array}$ & $\begin{array}{l}\text { 3.000,00 inicial e 2.000,00 } \\
\text { para um funcionário/mês. }\end{array}$ & Por mês \\
\hline $\begin{array}{l}\text { Fundo Regional de Apoio a } \\
\text { Pequenos Projetos }\end{array}$ & & $\begin{array}{l}200.000 \text { para os } \\
5 \text { primeiros anos }\end{array}$ \\
\hline
\end{tabular}




\section{Referências Bibliográficas da Sugestão de Programa de Educacão Ambiental} para a Bacia do Rio Corumbataí

DIAS, GENEBALDO F. Fundamentos de Educação Ambiental. In: MINISTÉRIO DA EDUCAÇÃO E CULTURA - MEC. Coordenação de Educação Ambiental. A Implantação da Educação Ambiental no Brasil. Brasília - DF, 1998.

MINISTÉRIO DA EDUCAÇÃO E CULTURA - MEC. Centros de Educação Ambiental: fundamentação e diretrizes. Brasília, 1994.

MINISTÉRIO DA EDUCAÇÃO E CULTURA - MEC. Educação Ambiental. In: MINISTÉRIO DA EDUCAÇÃO E CULTURA - MEC. Coordenação de Educação Ambiental. A Implantação da Educação Ambiental no Brasil. Brasília - DF, 1998.

MINISTÉRIO DA EDUCAÇÃO E CULTURA - MEC. Coordenação de Educação Ambiental. A Implantação da Educação Ambiental no Brasil. Brasília - DF, 1998.

MEADOWS, D. H. Harvesting one Hundredfold - Key Concepts and Case Studies in Environmental Education. In: SECRETARIA DO MEIO AMBIENTE. Conceitos Para se Fazer Educação Ambiental. A Secretaria, 1997.

MERGULHÃO, M. C., VASAKI, B. N. Educação Para a Conservação da Natureza: Sugestão de Atividades em Educação Ambiental. São Paulo: EDUC, 1998.

REPEA - Rede Paulista de Educação Ambiental. Por que desenvolver a rede de Educação Ambiental. Folheto distribuído na reunião para a formação do ELO PCJ, realizada na Prefeitura Municipal de Piracicaba. Março, 2001.

SECRETARIA DO MEIO AMBIENTE. Conceitos Para se Fazer Educação Ambiental. A Secretaria, 1997.

SORRENTINO, M. Educação Ambiental, Participação e Organização de Cidadãos. Coleção: Em Aberto. Brasília, 1991. 
PADUA, S. M. Apresentação. In: SECRETARIA DO MEIO AMBIENTE. Conceitos Para se Fazer Educação Ambiental. A Secretaria, 1997.

TROPPMAIR, H. Educação Ambiental. Departamento de Geografia / Instituto de Geociências e Ciências Exatas. UNESP - Rio Claro, 1997. 


\section{REFERÊNCIAS BIBLIOGRÁFICAS}

ACOT, P. História da Ecologia. 2.ed. Rio de Janeiro: Campus, 1990. 212p.

ADLER, P. A.; ADLER P. Observational Techniques. In: DENZIN, N. ; LINCOLN, Y. (Ed.) Handbook of Qualitative Research. California: Sage, 1994. cap.23, p.377392.

AGENDA 21. www.agenda21.org.br. (27 março 2001)

AGUIAR, R. Direito do Meio Ambiente e Participação Popular. Brasília: Ministério do Meio Ambiente e da Amazônia Legal e IBAMA, 1994. 109p.

ALVES, R. http://rubemalves.com.br. (07 out. 2001)

ARDOINO, J. L'analyse multiréférentielle des situations sociale. Revue de psychologie clinique. In: BARBOSA, J. (Coord.). Multireferencialidade nas Ciências e na Educação. São Carlos: Ed. UFSCar, 1998. p.119-125.

BRANDÃO, C. R. O Que é Educação. 33. ed. São Paulo: Brasiliense, 1995. 117p. (Coleção Primeiros Passos)

BRASIL. Leis, decretos, etc. Constituição da República Federativa do Brasil, Promulgada em 5 de outubro de 1988: Artigo no 225, Capítulo do Meio Ambiente. 29 ed. São Paulo: Saraiva, 2002. (Coleção Saraiva de Legislação) 
BRASIL. Leis, decretos, etc. Medida Provisória o 1.511 de 25 jullho 1996. Dispõe sobre alterações no Código Florestal Brasileiro. www.senado.gov.br. (15 julho 2000)

BRASIL. Leis, decretos, etc. Decreto no 3.420 de 20 de abril de 2000. Institui o Programa Nacional de Florestas. www.senado.gov.br. (10 nov. 2000)

BRASIL. Leis, decretos, etc. Lei o 4.771 de 15 de setembro de 1965. Institui o Código Florestal Brasileiro, alterado pela Lei oㅜ 7.803/89 e Medida Provisória. www.senado.gov.br. (20 março 2000)

BRASIL. Leis, decretos, etc. Lei no 9.795 de 27 de abril de 1999. Dispõe sobre a Política Nacional de Educação Ambiental. www.senado.gov.br. (20 julho 2000)

BRASIL. Leis, decretos, etc. Lei no 9.433 de 8 de janeiro de 1997. Institui a Política Nacional de Recursos Hídricos. www.senado.gov.br. (14 março 2001)

BRASIL. Leis, decretos, etc. Lei o 9.984 de 17 de julho de 2000. Cria a Agência Nacional de Águas. www.senado.gov.br. (19 set. 2000)

BRASIL. Leis, decretos, etc. Medida Provisória oㅜ 2166 de 2001. Utiliza-se do termo "microbacia" para disciplinar sobre a compensação de área de Reserva Legal. www.senado.gov.br. (20 nov. 2001)

BRASIL. Leis, decretos, etc. Lei o 9.605 de 12 de fevereiro de 1998. Institui a Lei de Crimes Ambientais. www.senado.gov.br. (12 junho 2000)

BRITO, M. C. Elaboração Participativa de uma Agenda XXI da Comunidade Caiçara do Pouso da Cajaíba. Piracicaba, 2000. 150p. Dissertação (Mestrado) - Escola Superior de Agricultura "Luiz de Queiroz", Universidade de São Paulo.

COODENADORIA DE ASSISTÊNCIA TÉCNICA INTEGRAL. Terra Amiga: Programa Estadual de Microbacias Hidrográficas. São Paulo, mar. 1998. 34p. 
CHAUI, M. Raízes do Atraso: Novo livro de Celso Furtado Analisa as Causas da Miséria Brasileira. Jornal de Resenhas, São Paulo, 11de mar. de 2000.

COSTA, L. R. Estratégias de Planejamento. Revista Ciência e Cultura, v.38, n.8, p.1366-1391, 1986.

CRUZ NETO, O. O Trabalho de Campo como Descoberta e Criação. In: MINAYO, M. (Org.). Pesquisa Social. Petrópolis: Vozes, 1996. cap. 3, p.51-65.

CUSTÓDIO, H. B. Direito à Educação Ambiental e à Conscientização Pública. Revista de Direito Ambiental, ano 5, n.18, p.38-56, abril-junho 2000.

DALLARI, D. A. O que é Participação Política. São Paulo: Brasiliense, 1984. 100p. (Coleção Primeiros Passos)

DELORS, J. Educação: um Tesouro a Descobrir. 2.Ed. São Paulo: Cortez, /199?/ $288 p$.

DENZIN, N.; LINCOLN, Y. (Ed.) Handbook of Qualitative Research. California: Sage, 1994. 643p.

DINIZ, C. Elaboração Participativa de um Plano de Gestão em Educação Ambiental para o Campus "Luiz de Queiroz" / Universidade de São Paulo. Piracicaba, 1999. 353p. Dissertação (Mestrado) - Escola Superior de Agricultura "Luiz de Queiroz", Universidade de São Paulo.

ECO, UMBERTO. O Irracionalismo Ontem e Hoje. Jornal Folha de São Paulo, São Paulo, 31 out. 1987. p.1-4.

FERREIRA, A. B. H. Minidicionário da Língua Portuguesa. 3. ed. Rio de Janeiro: Nova Fronteira, 1993. 577p. 
FERRETTI, A. R. O Fomento Florestal da CESP / Porto Primavera com Propriedades da Região de Assis-SP. Piracicaba, 2000. 156 p. Dissertação (Mestrado) - Escola Superior de Agricultura "Luiz de Queiroz", Universidade de São Paulo.

FONTANA, A.; FREY J. Interviewing. In: DENZIN, N.; LINCOLN, Y. (Ed.) Handbook of Qualitative Research. California: Sage, 1994. cap.22, p.361-376.

FREIRE, P. Extensão ou Comunicação? 10.ed. Rio de Janeiro: Paz e Terra, 1977. 93p.

FREIRE, P. Criando Métodos de Pesquisa Alternativa: Aprendendo a Fazê-la Melhor Através da Ação. In: BRANDÃO, C. R. (Org.). Pesquisa Participante. 8.ed. São Paulo: Brasiliense, 1990. p.35-62.

GERD, S.; LEPSCH, I. Diagnóstico de Uso e Aptidão das Terras Agrícolas de Piracicaba. Piracicaba: Editora, 1998. 99p.

GONZALEZ, E. T. Introdução ao Estudo de Direito e dos Ordenamentos Jurídicos. Piracicaba: UNIMEP, 2000. 167p.

GUATTARI, F. As Três Ecologias. Campinas: Papirus, 1991. 56p.

HAGUETTE, T. Metodologias Qualitativas na Sociologia. Petrópolis: Vozes, 1992. 224p.

HAUAISS, A. Pequeno Dicionário Enciclopédico Koogan Larousse. Rio de Janeiro: Editora Larousse, 1979. 1622p.

HUBERMAN, A.; MILES, M. Data Management and Analysis Methods. In: DENZIN, N.; LINCOLN, Y. (Ed.) Handbook of Qualitative Research. California: Sage, 1994. cap.27, p.428-444. 
INSTITUTO BRASILEIRO DE GEOGRAFIA E ESTATÍSTICA. Carta Geológica do

Estado de São Paulo. São Paulo, 1969. Escala 1:50.000.

INSTITUTO DE PESQUISAS E ESTUDOS FLORESTAIS - IPEF; SERVIÇO MUNICIPAL DE ÁGUA E ESGOTO DE PIRACICABA - SEMAE. Relatório de Novembro de 1999. Piracicaba: Projeto Corumbataí, 1999. 33p.

INSTITUTO DE PESQUISAS E ESTUDOS FLORESTAIS - IPEF; SERVIÇO MUNICIPAL DE ÁGUA E ESGOTO DE PIRACICABA - SEMAE. Relatório Bimestral Abril / Maio de 2000. Piracicaba: Projeto Corumbataí, 2000. 39p.

JANESICK, V. The Dance of Qualitative Research Design. In: DENZIN, N.; LINCOLN, Y. (Ed.) Handbook of Qualitative Research. California: Sage, 1994. cap. 12, p.209-219.

JORNAL DE PIRACICABA. Degradação do Corumbataí Avança. Piracicaba, 11 maio 2000. Capa.

JORNAL O GLOBO. Amazônia Sofre com Política de Terra Arrasada. Rio de Janeiro, 14 maio 2000. Capa.

LAGO, A.; PÁDUA, J. A. O que é Ecologia. Brasília: Brasiliense, 1985. 108p. (Coleção Primeiros Passos)

LAURAU, R. Multireferencialidade e Implicação. In: BARBOSA, J. (Coord.). Multireferencialidade nas Ciências e na Educação. São Carlos: EdUFSCar, 1998. p.119-125.

LEÃO, R. M. A floresta e o Homem São Paulo: EDUSP / Instituto de Pesquisas e Estudos Florestais, 2000. 434p. 
LEVANTAMENTO CENSITÁRIO DE UNIDADES DE PRODUÇÃO AGROPECUÁRIA LUPA. Piracicaba: Casa da Agricultura, 1995. /Material disponível para uso interno da Casa da Agricultura/

LIBÂNEO, J. C. Democratização da Escola Pública - A Pedagogia Crítico-social dos Conteúdos. São Paulo: Loyola, 1984. 151p.

LIBÓRIO, M. Código Florestal Brasileiro: Um Estudo Sobre as Relações Entre sua Eficácia e a Valorização da Paisagem Florestal no Sudoeste Paulista. Rio Claro, 1994. Tese (Doutorado) - Universidade Estadual Paulista "Júlio de Mesquita Filho".

LIMA , W. P.; ZÁKIA, M. J. B. Uso Consuntivo de Água em Microbacia Tributária da Bacia Hidrográfica do Rio Corumbataí. In: Simpósio Sobre Recuperação da Cobertura Florestal da Bacia do Rio Corumbataí, 3., Piracicaba, 2000. Anais. Piracicaba: Editora, 2000. 50p.

LUBCHENCO, J. Entering the Century of the Environment: A New Social Contract for Science. Science Maganize, v.279, n.5350, p.435-466, jan. 1998.

MACHADO, P. A. L. O Direito e a Proteção das Florestas no Século XXI. In: BENJAMIN, A. H. (Org.). Anais do 3 - Congresso Internacional de Direito Ambiental, 30 de maio a 02 de junho de 1999. São Paulo: IMESP, 1999. cap.1, p.7-14.

MACHADO, P. A. L. Direito Ambiental Brasileiro. 9. ed. São Paulo: Malheiros, 2000. $1031 p$.

MALAGODI, M. A. Estudo Sobre um Programa de Reflorestamento Ciliar: Subsídios para Compreensão das Relações entre Extensão Rural e Educação Ambiental. Piracicaba, 1999. 309 p. Dissertação (Mestrado). Escola Superior de Agricultura "Luiz de Queiroz", Universidade de São Paulo. 
MANZINE-COVRE, M. L. O que é Cidadania. 3. ed. São Paulo: Brasiliense, 1995. 79p. (Coleção Primeiros Passos)

MARTINS, R. A Morte Anunciada do Plano de Desenvolvimento Florestal Sustentável do Estado de São Paulo. Piracicaba, 2000. 101p. Dissertação (Mestrado). Escola Superior de Agricultura "Luiz de Queiroz", Universidade de São Paulo.

McCORMICK, J. Rumo ao Paraíso: A História do Movimento Ambientalista. Rio de Janeiro: Editora Relume Dumará, 1992. 220p.

MERLI, G. L. (Org.) Recuperação Florestal e Desenvolvimento Sustentável na Bacia do Rio Corumbataí: Situação e Perspectiva do Abastecimento de Água de Piracicaba. Piracicaba: SEMAE / Prefeitura Municipal de Piracicaba, 1999. 60p.

MICHEL, A. Código do Absurdo. Revista Época, v.2, n.104, maio 2000.

MINAYO, M. C. O Desafio do Conhecimento: Pesquisa Qualitativa em Saúde. 4. ed. Piracicaba: Hucitec-Abrasco, 1996. 269p.

MINISTÉRIO DA EDUCAÇÃO E CULTURA; Coordenação de Educação Ambiental. A Implantação da Educação Ambiental no Brasil. Brasília-DF, 1998. 166p.

MORIN, E. Os Setes Saberes Necessários para a Educação do Futuro. São Paulo: Cortez, 2000. 118p.

NOVO, M. V. Educacion Ambiental. Madrid: Ediciones Anaya S.A., 1985. 197p.

PERLIN, J. História das Florestas: A importância de madeira no desenvolvimento da civilização. Rio de Janeiro: Imago, 1992. 490p.

PROJETO CORUMBATAÍ. Mapa da Rede Hídrica da Microbacia Tamandupá. Piracicaba, 2001. Escala 1:100.000. 
REIGOTA, M. O que é Educação Ambiental. São Paulo: Brasiliense, 1994. 63p. (Coleção Primeiros Passos)

RIBEIRO, J. U. Política: Quem Manda, Por Que Manda, Como Manda. 3. ed. Rio de Janeiro: Nova Fronteira, 1998. 165p.

SANTOS, B. Pela Mão de Alice: O Social e o Político na Pós-modernidade. $3^{\text {a }}$ Ed. São Paulo: Cortez, 1997. 348p.

SIRKIS, A. Enquanto Isso, na Terra do Pau-brasil ... In: Rumo ao Paraíso - A História do Movimento Ambientalista. Rio de Janeiro, Editora Relume Dumará, 1992. /Apêndice/

SORRENTINO, M. Educação Ambiental e Universidade: Um Estudo de Caso. São Paulo, 1995. 335p. Tese (Doutorado). Universidade de São Paulo.

SORRENTINO, M. Universidade, Formação Ambiental e Educação Popular. Revista Temas em Educação, n. 4, p.85-89, 1995.

STAKE, R. Case Studies. In: DENZIN, N.; LINCOLN, Y. (Ed.) Handbook of Qualitative Research. California: Sage, 1994. cap.14, p.236-247.

SUNG, J. M. Conversando Sobre Ética e Sociedade. 5. ed. Petrópolis: Vozes, 2000. 117p.

TASSARA, E.; DAMERGIAN, S. Para um Novo Humanismo: Contribuições da Psicologia Social. Estudos Avançados, v.10, n. 28, 1996. p.307.

THIOLLENT, M. Metodologia da Pesquisa-ação. São Paulo: Cortez, 1986. 108p. (“Coleção Temas Básicos de ...")

TROPPMAIR, H. Educação Ambiental. Rio Claro: Instituto de Geociências e Ciências Exatas da UNESP, 1997. 42p. 
WHITESIDE, M. (Comp.) Diagnóstico (Participativo) Rápido Rural. Moçambique: Comissão Nacional do Meio Ambiente, 1994. 64p.

ZUBEN, N. A. V. A Emergência do Sujeito e a Educação. In: REZENDE, A.M. (Org.). Iniciação Teórica e Prática às Ciências da Educação. Petrópolis: Vozes, 1979. 220p. 